\title{
Detection systems for multiple-target in situ hybridization and immunocytochemistry
}

Citation for published version (APA):

Speel, E. J. M. (1995). Detection systems for multiple-target in situ hybridization and immunocytochemistry. [Doctoral Thesis, Maastricht University]. Datawyse / Universitaire Pers Maastricht. https://doi.org/10.26481/dis.19950420es

Document status and date:

Published: 01/01/1995

DOI:

10.26481/dis.19950420es

Document Version:

Publisher's PDF, also known as Version of record

\section{Please check the document version of this publication:}

- A submitted manuscript is the version of the article upon submission and before peer-review. There can be important differences between the submitted version and the official published version of record.

People interested in the research are advised to contact the author for the final version of the publication, or visit the DOI to the publisher's website.

- The final author version and the galley proof are versions of the publication after peer review.

- The final published version features the final layout of the paper including the volume, issue and page numbers.

Link to publication

\footnotetext{
General rights rights.

- You may freely distribute the URL identifying the publication in the public portal. please follow below link for the End User Agreement:

www.umlib.nl/taverne-license

Take down policy

If you believe that this document breaches copyright please contact us at:

repository@maastrichtuniversity.nl

providing details and we will investigate your claim.
}

Copyright and moral rights for the publications made accessible in the public portal are retained by the authors and/or other copyright owners and it is a condition of accessing publications that users recognise and abide by the legal requirements associated with these

- Users may download and print one copy of any publication from the public portal for the purpose of private study or research.

- You may not further distribute the material or use it for any profit-making activity or commercial gain

If the publication is distributed under the terms of Article $25 \mathrm{fa}$ of the Dutch Copyright Act, indicated by the "Taverne" license above, 


\section{DETECTION SYSTEMS FOR MULTIPLE-TARGET IN SITU HYBRIDIZATION AND IMMUNOCYTOCHEMISTRY}


Publication of this thesis was financially supported by:

University of Limburg

Dutch Organization for Scientific Research (NWO)

Becton Dickinson (The Netherlands)

BioRad (United Kingdom)

Boehringer (Germany)

Dako (Denmark)

\section{CIP-DATA KONINKLIJKE BIBLIOTHEEK, DEN HAAG}

Speel, Ernst Jan Maria

Detection systems for multiple-target in sitw hybridization and immunocytochemistry

Erinst Jan Maria Speel

Maastricht : Universitaire Pers Maastricht

Thesis Rijksuniversiteit Limburg Maastricht

With ref. - With summary in Dutch

ISBN $90-5278-178-8$

Subject headings: hybridization / immunocytochemistry / molecular cytogenetics 


\title{
DETECTION SYSTEMS FOR MULTIPLE-TARGET IN SITU HYBRIDIZATION AND IMMUNOCYTOCHEMISTRY
}

\author{
Proefschrift
}

\begin{abstract}
ter verkrijging van de graad van doctor
aan de Rijksuniversiteit Limburg te Maastricht, op gezag van de Rector Magnificus, Prof, mr. M.J. Cohen, volgens het besluit van het College van Dekanen, in het openbaar te verdedigen op donderdag 20 april 1995 om 14.00 uur

door

Ernst Jan Maria Speel
\end{abstract}

geboren op 21 september 1964 te 's-Hertogenbosch 


\section{Promotor:}

Prof. dr. F.C.S. Ramaekers

Co-promotor:

Dr. A.H.N. Hopman

\section{Beoordelingscommissie:}

Prof. dr. J.W. Arends (voorzitter)

Prof. dr. J.P.M. Geraedis

Dr. C.J.F, van Noorden (Universiteit van Amsterdam)

Dr. L. Snoeckx

Prof. dr. H.J. Tanke (Rijksuniversiteit Leiden)

\section{Cover illustration}

Merged confocal scanning laser microscopy image of the keratin cytoskeleton detected immunocytochemically with alkaline phosphatase-Fast Red combined with in situ hybridization signals for chromosome 1 detected with fluorescein isothiocyanate in a lung cancer cell.

The investigations described in this thesis were carried out at the Department of Molecular Cell Biology \& Genetics, Cardiovascular Research Institute Maastricht (CARIM), University of Limburg, Maastricht, The Netherlands. Part of the research was performed at the Department of Pathology, University Hospital Nijmegen, The Netherlands, and at the MRC Human Genetics Unit, Western General Hospital, Edinburgh, Scotland, U.K. 
Het is geweldig om te kunnen denken, hoe gewelddadig denken soms ook kan zijn. (Freek de Jonge) 


\section{CONTENTS}

Lilst of abbrevilations

Scope of this thesis

Chapter 1

Detection systems for in situ hybridization, and the combination with immunocytochemistry. Who is still afraid of Red, Green, and Blue?

Submitted for publication

Chapter 2

The effect of avidin-biotin interactions in detection systems for in situ hybridization.

$J$ Histochem Cytochem 40, 135-141, 1992

\section{Chapter 3}

A novel fluorescence detection method for in situ hybridization, based on the alkaline phosphatase-Fast Red reaction.

J Histochem Cytochem 40, 1299-1308, 1992

Chapter 4

Multicolor preparations for in situ hybridization using precipitating enzyme cytochemistry in combination with reflection contrast microscopy. Histochemistry 100, 357-366, 1993

\section{Chapter 5}

A novel triple-color detection procedure for brightfield microscopy, combining in situ hybridization with immunocytochemistry.

J Histochem Cytochem 42,1299-1307, 1994

Chapter 6

Combined immunocytochemistry and fluorescence in situ hybridization for simultaneous, tricolor detection of cell cycle, genomic and phenotypic parameters of tumor cells.

J Histochem Gytochem 42,961-966, 1994 
Multi-PRINS: Multiple sequential oligonucleotide primed in situ DNA synthesis reactions label specific chromosomes and produce bands.

Hum Genet 95, 29-33, 1995

Chapter 8

Rapid detection of oligonucleotide primed in situ (PRINS) labeled DNA in metaphase preparations, tissue sections, and immunostained cells.

Summary

Samenvatting

List of publications

Enzyme cytochemical reaction protocols for ISH and ICC

Dankwoord

Curriculum vitae 


\section{Abbrewiations}

\begin{tabular}{|c|c|}
\hline $\mathrm{ABC}$ & : avidin biotinylated enzyme (APase, $G O$, or $P O$ ) complex \\
\hline $\mathrm{AEC}$ & : 3,3-amino-9-ethyl carbazole \\
\hline AMCA & : amino methyl coumarin acetic acid \\
\hline APase & : alkaline phosphatase \\
\hline Av & : avidin \\
\hline AVAMCA & : AMCA-conjugated avidin \\
\hline AvAPase & : APase-conjugated avidin \\
\hline Av/BioAPase & : avidin biotinylated APase complex \\
\hline Av/BioGO & : avidin biotinylated GO complex \\
\hline AvFITC & : FITC-conjugated avidin \\
\hline AvPO & : PO-conjugated avidin \\
\hline AvTRITC & : TRITC-conjugated avidin \\
\hline AvTXRED & : TXRED-conjugated avidin \\
\hline $\mathrm{BCIG}$ & : 5-bromo-4-chloro-3-indolyl-B-D-galactoside \\
\hline BCIP & : 5-bromo-4-chloro-3-indolyl-phosphate \\
\hline BFM & : brightfield microscopy \\
\hline B-Gal & : B-galactosidase \\
\hline BioAPase & : biotinylated APase \\
\hline BiOGAA & : biotinylated polyclonal goat anti-avidin \\
\hline BioGAR & : biotinylated polyclonal goat anti-rabbit IgG \\
\hline BioHAM & : biotinylated polyclonall horse anti-mouse IgG \\
\hline BioPO & : biotinylated $\mathbb{P O}$ \\
\hline $\mathrm{bp}$ & : basepairs \\
\hline BrdU & : bromodeoxyuridine \\
\hline BSA & : bovine serum albumin \\
\hline BT & : biotinylated tyramine \\
\hline CARD & : catalyzed reporter deposition (system) \\
\hline $\mathrm{CCD}$ & : charge-coupled device (camera) \\
\hline CSLM & : confocal scanning laser microscopy \\
\hline DAB & : diaminobenzidine \\
\hline DABCO & : 1,4-di-azobicyclo-(2,2,2)-octane \\
\hline DAPI & : 4',6-diamino-2-phenyl indole \\
\hline DSSS & : dioctyl sodium sulfosuccinate \\
\hline EGF & : epidermal growth factor \\
\hline EM & : electron microscopy \\
\hline FITC & : fluorescein isolhiocyanate \\
\hline GAMAPase & : APase-conjugated polyclonal goat anti-mouse $\operatorname{lgG}$ \\
\hline GO & : glucose oxidase \\
\hline $\mathrm{ICC}$ & ; immunocytochemistry/immunocytochemical \\
\hline $\operatorname{IgG}$ & : immunoglobulin $\mathrm{G}$ \\
\hline ISH & : in situ hybridization \\
\hline $\mathrm{kb}$ & : kilobasepairs \\
\hline
\end{tabular}




$\begin{array}{ll}\text { Ki67-Ag } & \text { : Ki67 antigen } \\ \text { MAb } & \text { : monoclonal antibody } \\ \text { MABio } & : \text { monoclonal mouse anti-biotin } \\ \text { MADig } & : \text { monoclonal mouse anti-digoxin } \\ \text { MAFITC } & : \text { monoclonal mouse anti-FITC } \\ \text { Mb } & : \text { megabasepairs } \\ \text { Mw } & : \text { molecular weight } \\ \text { NA } & : \text { numerical aperture } \\ \text { N-ASGR-P } & : \text { naphthol-ASGR-phosphate } \\ \text { N-ASMX-P } & : \text { naphthol-ASMX-phosphate } \\ \text { NBT } & : \text { nitro blue tetrazolium } \\ \text { N-CAM } & : \text { neural cell adhesion molecule } \\ \text { NGS } & : \text { normal goat serum } \\ \text { PBS } & : \text { phosphate-buffered saline } \\ \text { PCR } & : \text { polymerase chain reaction } \\ \text { PI } & : \text { propidium iodide } \\ \text { PMS } & : \text { phenozine methosulphate } \\ \text { PO } & : \text { horseradish peroxidase } \\ \text { PPD } & : \text { p-phenylenediamine } \\ \text { PRINS } & : \text { primed in situ (DNA synthesis) } \\ \text { PVA } & : \text { polyvinyl alcohol } \\ \text { RADig } & : \text { polyclonal rabbit anti-digoxin } \\ \text { RAFITC } & : \text { polyclonal rabbit anti-FITC } \\ \text { RAMFITC } & : \text { FITC-conjugated polyclonal rabbit anti-mouse IgG } \\ \text { RAMPO } & : \text { PO-conjugated polyclonal rabbit anti-mouse IgG } \\ \text { RCM } & : \text { reflection contrast microscopy } \\ \text { RT } & : \text { room temperature } \\ \text { StrAv/BioAPase } & : \text { steptavidin biotinylated APase complex } \\ \text { StrAvFITC } & : \text { FITC-conjugated steptavidin } \\ \text { SWARAPase } & : \text { APase-conjugated polyclonal swine anti-rabbit IgG } \\ \text { SWARPO } & : \text { PO-conjugated polyclonal swine anti-rabbit IgG } \\ \text { TMB } & : \text { tetramethylbenzidine } \\ \text { TO } & : \text { Thiazole Orange } \\ \text { TRITC } & : \text { tetramethylrhodamin isothiocyanate } \\ \text { TxRED } & : \text { Texas Red } \\ \text { YAC } & : \text { yeast artificial chromosome } \\ & \end{array}$





\section{SCOPE OF THIS THESIS}

The in situ hybridization (ISH) technique offers the possibility to localize nucleic acid sequences in microscopic preparations of tissues, cells, chromosomes, and linear DNA fibers. Since its introduction at the end of the 1960 s, much progress has been made as a result of optimization of the technique, including preparation of the biological material, nucleic acid probe production, the development of easy nonradioactive probe labeling methods, improvements in cytochemical detection procedures, and the development of sensitive microscopes and image analysis systems. This has resulted in broad application of the ISH technique in biomedical research as well as in clinical diagnosis, making it an integral part of studies concerning gene mapping, gene expression, the analysis of nuclear organization, prenatal diagnosis, tumor diagnosis, or microbial infections. The currently used nonradioactive. ISH detection systems are reviewed in detail in chapter 1 and compared with respect to sensitivity, resolution, and multiple-target detection. Furthermore, approaches are described for the simultaneous visualization of nucleic acid sequences and proteins by combining the ISH technique with protein immunocytochemistry.

The aim of this thesis was to contribute to the further development and general applicability of the ISH technique. For this purpose, investigations were carried out to unravel the molecular complex formation in ISH detection procedures. In addition, new and reliable detection protocols were developed for application in different types of microscopy, i.e., fluorescence, brightfield, and reflection contrast microscopy. These protocolls could be used for single-target ISH and, moreover, combined with each other in multiple-color detection procedures for the simultaneous visualization of different DNA sequences and cellular proteins. The primed in situ (PRINS) labeling reaction has been examined as a possible alternative for ISH to detect nucleic acid sequences in situ. 



\section{CHAPTER 1}

\section{DETECTION SYSTEMS FOR IN SITU HYBRIDIZATION, AND THE COMBINATION WITH IMMUNOCYTOCHEMISTRY}

"Who is still afraid of Red, Green, and Blue?"

Ernst JM Speel, Frans CS Ramaekers, Anton HN Hopman

Submitted for publication

\section{ABSTRACT}

An overview is given of the different non-radioactive cytochemical detection methodologies that are currently utilized to localize nucleic acid sequences in chromosomes, cells, and tissue sections. Dependent on the reporter molecule (fluorochrome, enzyme, or hapten) that is used to modify the appropriate nucleic acid probe, and the sensitivity that is required, the in situ hybridized sequences can be detected either directly after hybridization, or indirectly, using cytochemical detection and amplification layers. These may then contain antibody and/or avidin molecules conjugated to fluorochromes, enzymes, or colloidal gold particles. Since the choice of a suitable probe-labeling method in combination with a fluorescence, enzyme cytochemical, or immunogold-silver detection procedure is often determined by the user's own practical experience and applications, the different detection methodologies are compared with each other in detail with respect to sensitivity, resolution, applicability for multiple probe detection, and stability. Also aspects concerning evaluation of the resulting in situ hybridization (ISH) signals will be discussed. The advantages and disadvantages of the various procedures described here may help in selecting the most appropriate detection methodology for one's own experimental design. Furthermore, procedures are reviewed for the combination of ISH with immunocytochemical detection of proteins and/or incorporated bromodeoxyuridine, which allow the simultaneous visualization of genomic, phenotypic, and/or cell cycle parameters in the same sample. Possible improvements with respect to sensitivity, specificity, and multiplicity of the detection methods are finally being discussed. 


\section{INDEX}

A Introduction

B In situ detection of labeled nucleic acid sequences

$\begin{array}{ll}1 & \text { Detection schemes } \\ 2 & \text { Detection with fluorochromes } \\ 2.1 & \text { Conventional flworescence detection } \\ 2.2 & \text { Time-resolved fluorescence detection } \\ 3 & \text { Enzyme cytochemical detection } \\ 3.1 & \text { Detection with brightfield microscopy } \\ 3.2 & \text { Detection with reflection contrast microscopy } \\ 3.3 & \text { Detection with fluorescence microscopy } \\ 3.4 & \text { Detection with atowic force microscopy } \\ 3.5 & \text { Chemiluminescence detection } \\ 4 & \text { Detection with colloidal gold } \\ 5 & \text { Analysis of in situ hybridization signals }\end{array}$

C Combination of immunocytochemistry and in situ hybridization

D Concluding remarks and future prospects

E Protocols

F References

\section{A. INTRODUCTION}

In situ hybridization (ISH) has become an important tool for the detection of specific nucleic acid sequences (DNA and RNA) in morphologically preserved chromosomes, cells, and tissue sections. Although the first ISH procedures made use of radioisotopes (Gall and Pardue, 1969; John et al., 1969; Gerhard et al., 1981; Harper et al., 1986), the ISH application of nucleic acid probes that are modified with stable, non-radioactive labels has overcome the use of radioactivity in these procedures to a large extent. Since its introduction in the late 1970s (Rudkin and Stollar, 1977; Bauman et al. 1980), the impact of non-radioactive ISH in biomedical research and clinical diagnosis has been tremendous. This has been the result of continuous improvements in the different steps that are essential for successful ISH, i.e., specimen preparation, probe selection and labeling, cytochemical detection, and microscopy (Figure 1).

Preparation of cells and tissue sections for ISH usually involves routine fixation and attachment of the material to a solid support (glass slides or EM grids), followed by pretreatments (e.g., proteolytic digestion) to allow penetration of the labeled nucleic acid probes and cytochemical detection molecules. This requires a delecate balance between preservation of cell morphology and the efficiency of the ISH procedure. Currently, ISH can be applied on tissue sections, metaphase and interphase cell preparations (for reviews, see, e.g., Hopman et al., 1988a, 1988b, 1990, 1991; Terenghi 


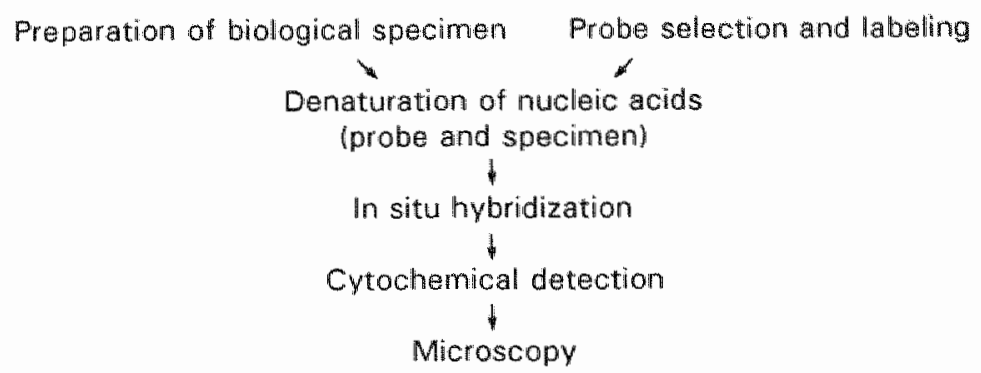

Figure 1. Schematic overview of the ISH procedure.

and Fallon, 1990; Lichter et al., 1991; Boehringer manual, 1992; Amersham manual, 1993; Leitch et al., 1994), as well as linear DNA fibers (Wiegant et al., 1992; Buckle and Kearney, 1993; Parra and Windle, 1993; Haaf and Ward, 1994), with a detection sensitivity of maximally $1 \mathrm{~kb}$ of target DNA.

Three types of probes are mainly used for ISH, i.e., double-stranded DNA probes, single-stranded RNA probes, and oligonucleotide probes. At present, the availability of a large number of molecular cloning techniques, including plasmid-, phage-, P1-, cosmid-, and yeast artificial chromosome (YAC) cloning procedures, cell hybrid technology, chromosome sorting- and dissection techniques, and polymerase chain reaction (PCR) techniques, have led to the production and application of a large variety of DNA and RNA probes (Matthews and Kricka, 1988; Terenghi and Fallon, 1990; Pollard-Knight, 1990; Leitch et al., 1994; Hopman et al., 1995). In addition, oligonucleotides can be chemically synthesized using automated DNA synthesizers. Depending on the choice of the probe, different target sequences will be detected, including specific genomes, chromosomes, repetitive or unique DNA sequences, $\mathrm{mRNA}$, and viral sequences.

In the last fifteen years many hapten labeling methods have been developed, based on chemical or enzymatic modification of nucleic acid sequences (for reviews, see Matthews and Kricka, 1988; Raap et al., 1989; Pollard-Knight, 1990; Terenghi and Fallon, 1990; Boehringer manual, 1992; Leitch et al., 1994; Hopman et al., 1995). At the moment enzymatic incorporation of nucleotides modified with biotin, digoxigenin, dinitrophenyl, or fluorochromes, such as fluorescein, rhodamin and coumarin, is usually preferred over chemical labeling techniques, also since there are a number of enzymatic probe labeling kits commercially available (see Table 1). In addition, target DNA and RNA sequences can be detected by means of the primed in situ (PRINS) labeling technique. A hybridized unlabeled DNA probe (oligonucleotide, cloned DNA, or PCR product) then serves as primer for in situ chain elongation catalyzed by a DNA polymerase or reverse transcriptase, which incorporates labeled nucleotides (see Table 1) (Koch et al., 1989, 1991; Gosden et al., 199lb; Mogensen et al., 1991; Bains et al., 1993; Gosden and Lawson, 1994; Hindkjwer et al., 1994; Speel et al., 1995) (see Table 1). 


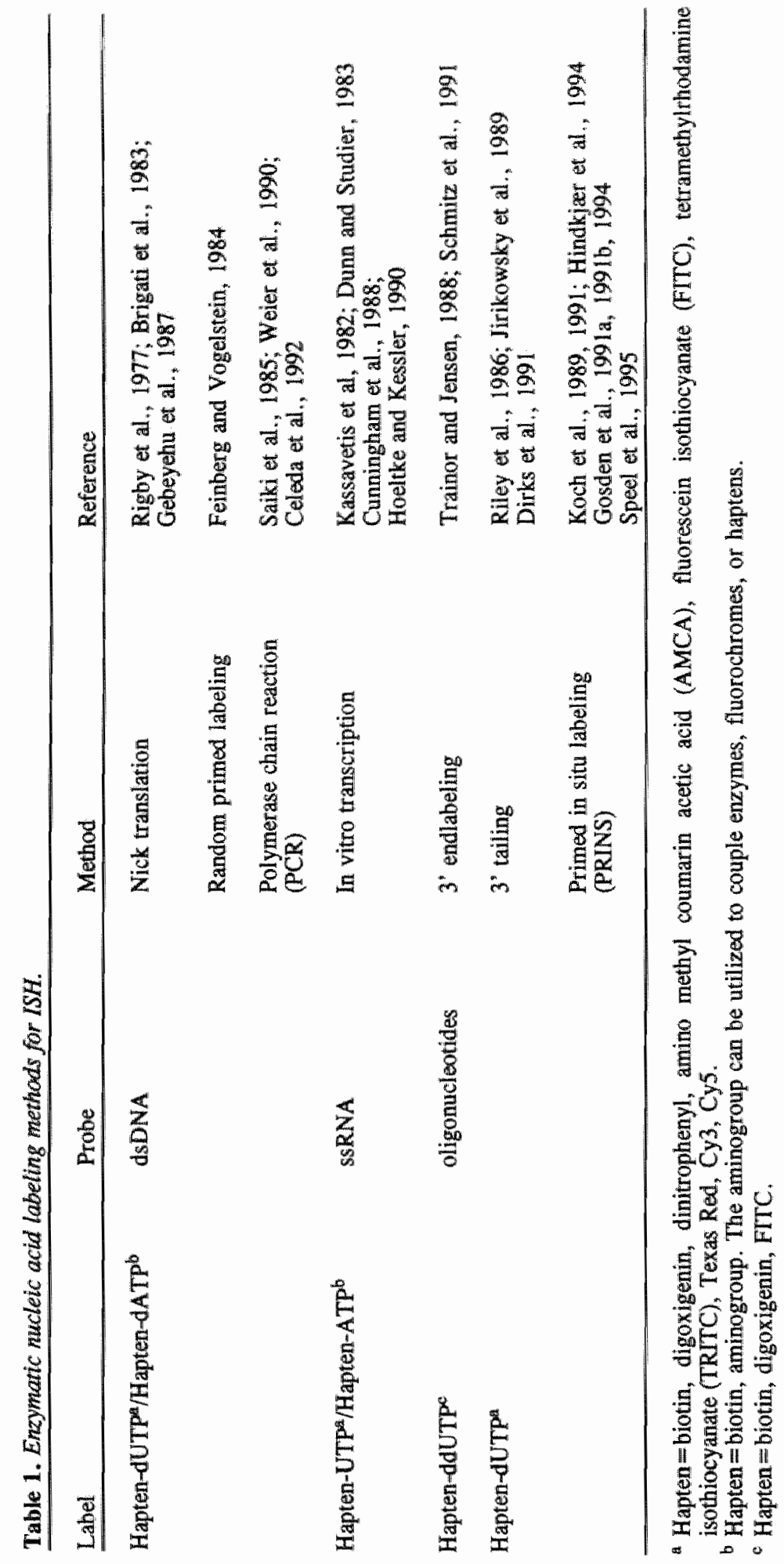


Next to specimen and probe preparation methods, the success of the ISH technique has been the result of the availability of a large variety of cytochemical detection reagents. Also the possibility to combine a number of probe-labeling and detection schemes for the simultaneous detection of two or more nucleic acid sequences in different fluorescence or absorption colors within the same cell preparation (Hopman et al., 1986; Nederlof et al., 1989; Ried et al., 1992; Dauwerse et al., 1992; Speel et al., 1994b) have provided a significant step forward. Finally, the quality of light microscopes and imaging systems has improved considerably and facilitated evaluation of ISH results (Tanke, 1989; Boehringer manual, 1992; Leitch et al, 1994). To give more insight in the pros and cons of the available non-radioactive detection systems for ISH, we will discuss nucleic acid sequence detection using fluorescence, enzyme cytochemical, or colloidal gold-silver procedures, and compare these methods with respect to sensitivity, resolution, multiplicity, stability of the ISH signals, and evaluation. In addition, we describe the possibilities to combine nonradioactive ISH with the immunocytochemical (ICC) detection of proteins and/or incorporated bromodeoxyuridine ( $\mathrm{BrdU})$, enabling the visualization of multiple paramelers in a cell, thus allowing to relate gene topography to gene activity at the DNA, mRNA, and protein level.

\section{B. IN SITU DETECTION OF LABELED NUCLEIC ACID PROBES}

\section{DETECTION SCHEMES}

Following probe hybridization, stringent washing steps, and blocking with reagents such as non-fat dry milk, bovine serum albumin (BSA), or normal serum to prevent aspecific binding of the detection molecules to the cells or to the glass slide, the sites of hybridization can be detected dependent on the type of label incorporated into the probe. The simplest way to visualize nucleic acid targets is to use fluorochromelabeled nucleic acid probes (Table 1), so that after ISH the site of hybridization can be localized directly by its fluorescence color (Wiegant et al., 1993). Alternatively, enzymes such as horseradish peroxidase (PO) or alkaline phosphatase (APase) can be chemically conjugated to nucleic acid probes, which makes it possible to localize the hybridization sites with enzyme precipitation reactions (Kiyama and Emson, 1991). The use of these direct detection systems avoids background noise that otherwise can be induced by the application of cytochemical detection layers. In most cases, however, a higher detection sensitivity is needed than provided by these direct techniques, which can be achieved by using cytochemical amplification systems (Figure 2). These systems are the result of the continuous advances made in ICC in the past two decades (see, e.g., Larsson, 1988) and are based on the fact, that most probe labels are immunogenic and can be detected by antibodies raised against these labels (Systems 1-5 and 8-9 in Figure 2). In addition, the hapten biotin can be detected with the avidin-biotin system (Systems 6 and 7, Figure 2), which is based on the high affinity $\left(K_{\mathrm{a}}=10^{15} \mathrm{M}^{-1}\right)$ of avidin, a glycoprotein extracted from egg white 


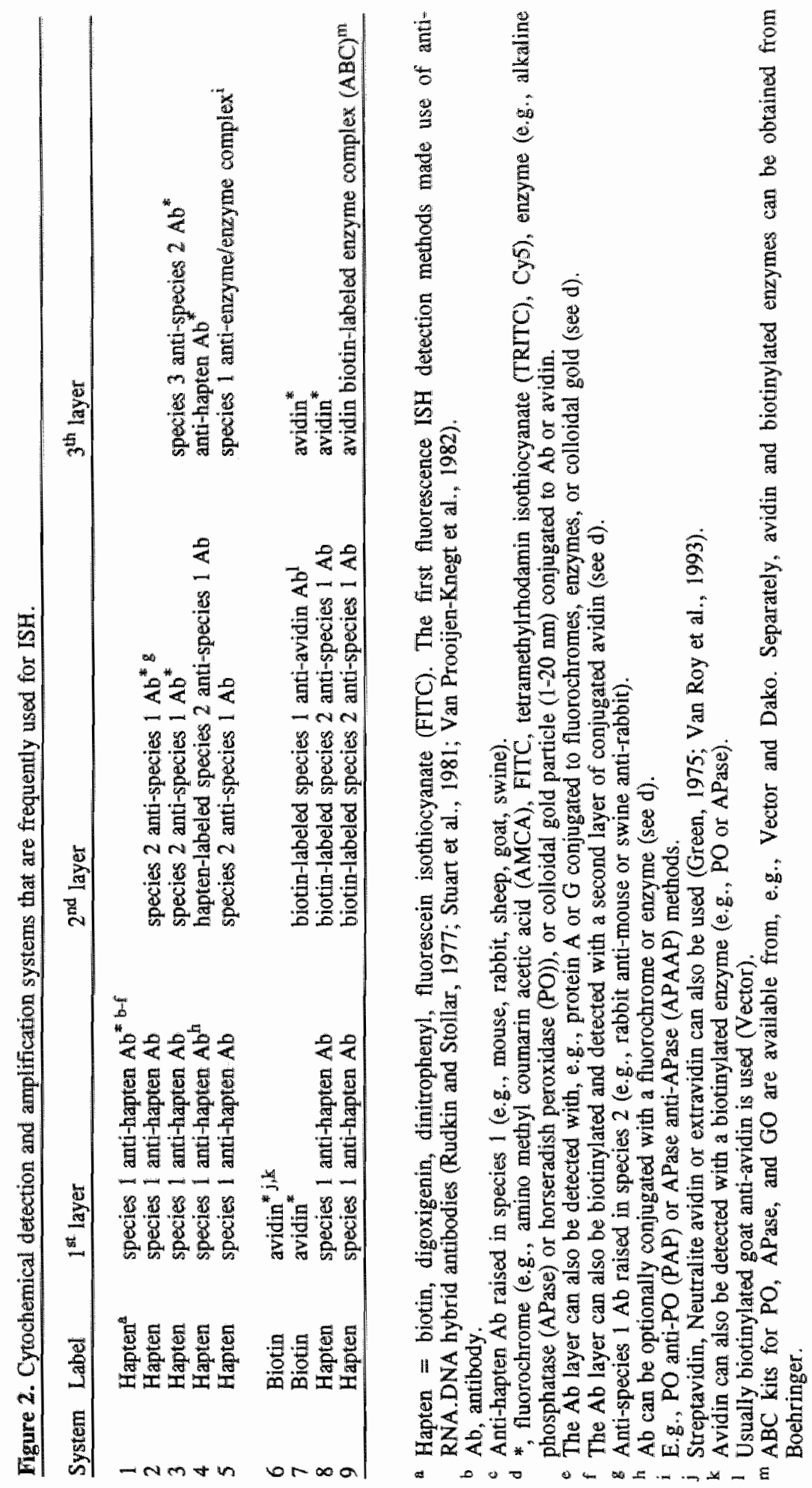




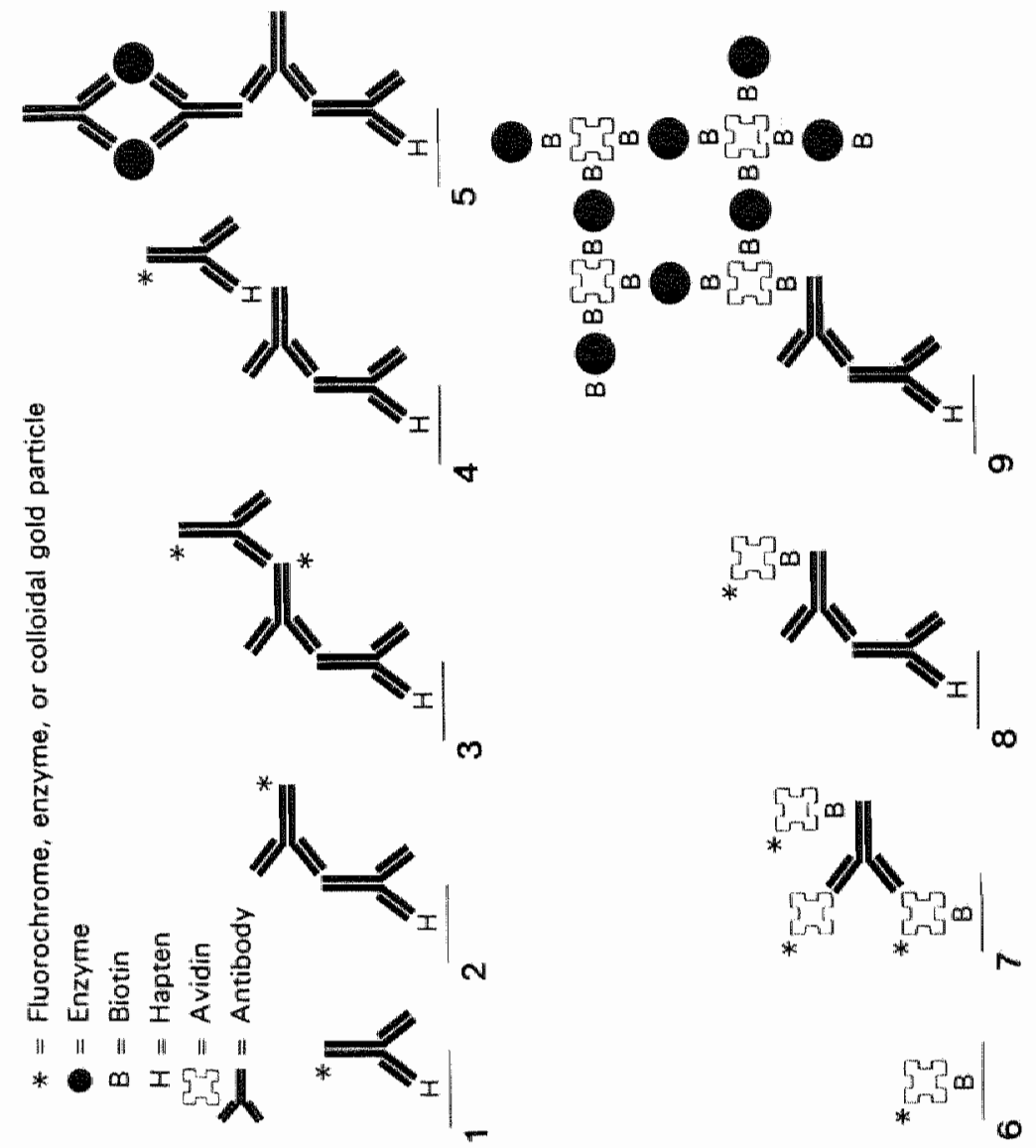


with a molecular weight of $60 \mathrm{kd}$, to biotin (Green, 1975). In principle, every probe labeling method can be combined with a fluorescence, enzyme cytochemical, or colloidal gold-silver visualization procedure, except for Systems 5 and 9 which are only applicable in combination with enzyme cytochemistry. The presented detection systerns vary from directly conjugated primary antibodies or labeled avidin (one-step detection, Systems 1 and 6) to more sensitive two- and three step detection systems (Systems 2-5 and 7-9).

The sensitivity of each system will depend on both the number of fluorochromes, enzymes, or gold particles that are introduced by the cytochemical detection steps and the signal-to-noise ratio. Detection systems 3,5,7, and 9 can be considered to be the most sensitive. Particularly the amplification of fluorochrome-conjugated avidin by means of biotinylated anti-avidin antibodies and repeated application of fluorochromeconjugated avidin (Figure 2, System 7) has been used extensively for ISH, showing 68 fold amplification in fluorescence intensity (Pinkel et al., 1986; Speel et al, 1992a). The signal-to-noise ratio will depend on the amount of aspecifically bound probe and detection molecules within cells or on the glass slide (background) in relation to the signal intensity caused by the specific cytochemical networks accumulated on the hybridized probe. Several protocols have been developed to reduce this aspecific binding, including the use of acetic anhydride (Hayashi et al., 1978; Lawrence and Singer, 1985), detergents (such as Triton X-100, Tween 20, and SDS), ficoll, polyvinyl pyrollidone, heparin, and BSA (Terenghi and Fallon, 1990), denatured and sonicated unlabeled genomic DNA and/or tRNA as carrier, and unlabeled avidin or streptavidin to block endogenous biotin within certain cell and tissue types (e.g., liver and kidney) (Naoumov et al., 1988). For protocols that reduce intrinsic enzyme activity see below.

Cytochemical detection steps are usually performed for $20-30$ min at $37^{\circ} \mathrm{C}$. Antibody conjugates are incubated in $150 \mathrm{mM}$ salt buffers (Phosphate, phosphate-buffered saline (PBS) or Tris $/ \mathrm{HCl}$ ) containing $2-5 \%$ normal serum as a blocking reagent, whereas avidin conjugates are diluted in $0.6 \mathrm{M}$ salt solution (4xSSC) containing $5 \%$ non-fat dry milk as a blocking reagent. We will now describe successively the detection of labeled nucleic acid probes by means of fluorescence, enzyme cytochemistry, and immunogold-silver cytochemistry.

\section{DETECTION WITH FLUOROCHROMES}

\subsection{Conventional fuorescence detection}

The use of fluorescence detection protocols provides a number of advantages for ISH, including easy and rapid detection of the fluorochrome-labeled probes, high sensitivity with low endogenous background, high resolution, multiple-target analysis with different fluorochromes, and the possibility to quantitate signal intensity. Next to direct detection, nucleic acid probes can also be localized indirectly using antibody or avidin molecules conjugated with fluorochromes. Fluorochromes are excited at an appropriate wavelength (excitation wavelength), after which the emitted fluorescence 
Table 2. Fluorochromes used for in situ probe detection and DNA counterstaining.

\begin{tabular}{llll}
\hline Fluorochrome & $\begin{array}{c}\text { Excitation } \\
\text { optimum }\end{array}$ & $\begin{array}{c}\text { Emission } \\
\text { optimum }\end{array}$ & Fluorescence color \\
\hline
\end{tabular}

Probe detection

\begin{tabular}{llll} 
AMCA $^{\text {b }}$ & 345 & 425 & Blue \\
FITC & 490 & 525 & Green \\
TRITC & 540 & 580 & Rad \\
Cy3 & 575 & 605 & Red \\
Texas Red & 590 & 615 & Red \\
Cy5 & 640 & 705 & Far-red \\
\hline
\end{tabular}

DNA counterstain

\begin{tabular}{lccc} 
DAPI & 355 & 450 & Blue \\
Hoechst 33258 & 356 & 465 & Blue \\
PI & $340 / 530$ & 615 & Red \\
\hline
\end{tabular}

" For detailed information concerning fluorochrome spectra, see, e.g., Khalfan et al., 1986; Ernst et al ., 1989; Mujundar et al, 1989; Haugland, 1994.

b Abbreviations used: AMCA, amino methyl coumarin acetic acid; FTC, fluorescein isothiocyanate; TRTTC, tetramethylrhodamin isothiocyanate; DAPI, 4",6-diamino-2-phenyl indole; PI, propidium iodide.

can be imaged using appropriate emission filters. There are now a number of fluorochromes available with good spectral separation properties (see Table 2). However, the fluorochrome Cy5 can only be used efficiently in combination with image generating and analysis systems, such as cooled charge-coupled device (CCD) camera systems and confocal scanning laser microscopy (CSLM), since its emission spectrum lies in the far red. Therefore, with conventional fluorescence microscopy, one can utilize a blue, green, and red fluorochrome simultaneously in one ISH experiment. Especially the development of dual and triple bandpass filter sets to visualize two or three fluorochromes simultaneously in one image has been important (Johnson et al., 1991; Dauwerse et al., 1992), since they prevent image shifts caused by switching from one single bandpass filter set to another. At the end of the cytochemical detection procedure, the cellular DNA can be counterstained with, e.g., blue fluorescent 4',6-diamino-2-phenyl indole (DAPI) or red fluorescent propidium iodide (PI), although also a number of other counterstaining reagents are available (Santisteban et al., 1992; Haugland, 1994). These are usually added to the embedding medium, which may further contain an anti-fading reagent, such as 1,4-di-azobicyclo(2,2,2)-octane (DABCO), p-phenylenediamine (PPD), or n-propyllgallate (Giloh and Sedat, 1982; Johnson et al., 1982; Böck et al., 1985; Krenik et al., 1989; Florijn et al., 1995). Especially the embedding medium Vectashield from Vector (Brunschwig Chemie, Amsterdam, The Netherlands) has been recommended for its strong antifading properties (Florijn et al,, 1995), although this medium shows some autofluorescence during UV excitation and appeared to slightly reduce the relative 
fluorescence intensity of the fluorochromes amino methyl coumarin acetic acid (AMCA), fluorescein isothiocyanate (FITC), and tetramethylrhodamin isothiocyanate (TRITC).

With TRITC- and FITC-labeled probes and conventional fluorescence microscopy, a sensitivity can be reached in the order of $30-40 \mathrm{~kb}$, sufficient to visualize cosmidsized targets on chromosome preparations (Wiegant et al., 1993). Unique target sequences $(1-5 \mathrm{~kb})$, which can only be detected with the aid of a CCD camera when directly labeled nucleic acid probes are used (Wiegant et al., 1991, 1993), can be visualized with conventional fluorescence microscopy using amplification detection systems (such as System 7, Figure 2). The sensitivity for mRNA detection appears to be in the order of the expression of house-keeping genes, although also 10-fold lower expression levels are expected to be detectable (Dirks et al., 1993).

The smallest physical distance between two different DNA target sequences that can be resolved by fluorescence ISH is dependent on the spatial resolution of the microscope used and on the degree of DNA condensation in the biological specimen under study (chromosomes, interphase nuclei, linear DNA). Until now, the resolution is 1-3 Mb on condensed DNA in metaphase chromosomes (Lichter et al., 1990), 50$100 \mathrm{~kb}$ on less condensed DNA in interphase nuclei (Trask et al., 1989), and in the order of $1 \mathrm{~kb}(=0.32 \mu \mathrm{m}$ on double stranded DNA) on linear DNA fibers (Wiegant et al., 1992; Parra and Windle, 1993; Houseal et al., 1994), which almost equals the maximal resolution of the fluorescence microscope $(0.2 \mu \mathrm{m})$.

On basis of different fluorescence colors multiple nucleic acid targets can be localized in the same cell preparation. For this purpose, multiple probes are differently labeled, mixed at the correct concentration into the same hybridization mixture, and used in an ISH experiment. After hybridization, the probes must be detected cytochemically without inducing cross-reactivity between the different detection systems. To detect three nucleic acid probes simultaneously, one can utilize the fluorochromes AMCA, FITC, and TRITC, when applying appropriate excitation and emission bandpass filters (Nederlof et al., 1989). Although directly fluorochrome-labeled nucleic acid probes can be used, most often a combination of a biotin-, digoxigenin-, and FITClabeled probe is taken, since for each of these labels there are amplification systems available (see Figure 2, and Figure $3 a$ and $3 b$ ). In the near future also antibodies against the fluorochromes AMCA, TRITC, TxRed, Cy3, and Cy5 are to be expected for use in such amplification systems. A schematic overview of the fluorescence detection procedure of three DNA targets in interphase and metaphase preparations is given in Protocol 1 (p. 40). The same detection scheme has also been used for the simultaneous detection of up to twelve different DNA targets in situ (Dauwerse et al., 1992). Such an approach requires combinatorial labeling of probes with multiple haptens in various ratios. A fluorescence microscope with high-transmission multiple bandpass filters, as well as a digital camera and image processing software for pseudocolor presentation of the ISH signals is needed (Ried et al., 1992; Lengauer et al., 1993). The use of the fluorochrome Cy5 may result in increased multiplicity of this method. Despite the advantages of fluorescence detection of mucleic acid target sequences, it also has some disadvantages, including fading of the fluorescence signal 
upon exposure to light, the significant autofluorescence in, for example, formalinfixed, paraffin-embedded tissue sections, as well as economical and practical considerations concerning the microscopical and imaging equipment needed. Therefore, other ways of probe detection have been investigated. To circumvent the problem of autofluorescence, time-resolved fluorescence detection or CSLM have been explored (Thompson et al., 1994). To obtain non-fading ISH signals and permanent preparations, enzyme cytochemical and immunogold-silver detection systems have been utilized.

\subsection{Time-resolved fluorescence detection}

Autofluorescence is the fluorescence signal which is emitted by the organic compounds in a biological specimen upon exposure to light, and which has a very short decay time $(<100 \mathrm{nsec})$. Therefore, if a cell preparation is exposed to a light pulse of a few microseconds and the fluorescence detection is delayed correspondingly, no autofluorescence will be observed in the image. This has been succesfully realized in time-resolved microscopes. Therefore, labels which emit fluorescence with a long decay time $(>10 \mu \mathrm{s})$ can be observed without interference of autofluorescence. Lanthanide chelates (such as europium chelates) with a decay time of $10-1000 \mu \mathrm{s}$ and crystalline phosphors activated by europium have been proposed as useful labels (Soini et al., 1988; Beverloo et al, 1990). The crystals have the advantage not to fade under excitation and have been used for the localization of cell surface antigens (Beverloo et al., 1990). However, at present no results have been reported concerning their intracellular use, probably caused by the large size of the crystals. In contrast, the small size of europium chelates have been utilized successfully for the localization of extra- and intracellular antigens as well as mRNA and DNA targets in tissue sections (Seveus et al., 1992). For this purpose, a stable fluorescent europium chelate was coupled to secondary antibodies and streptavidin, which were used for the detection. Despite the low overall fluorescence intensity of the europium chelate, the time-resolved procedure proved to be reasonably sensitive. Although the instability of the lanthanide chelate is still a serious problem under excitation and in connection with DNA counterstains, further improvements in the chemistry of chelates can make time-resolved fluorescence detection an interesting alternative for conventional fluorescence detection.

\section{ENZYME CYTOCHEMICAL DETECTION}

Enzymes coupled to avidin or antibody molecules and commonly used in ICC are also available for ISH. These enzymes can catalyze the precipitation of a visible product at the hybridization site. The reaction products can be analyzed by different types of microscopy (Table 3).

The choice of an enzyme depends on the biological material examined. Since some tissues contain endogenous enzyme activity, this must be blocked to prevent the formation of unacceptable background. Elimination of, e.g., endogenous APase and 


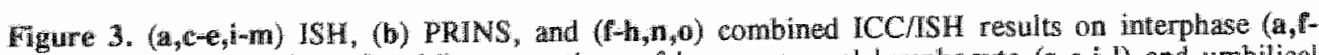
$h, j, k, m-0)$ and metaphase $\left(b-c_{y}, i, l\right)$ preparations of human normal lymphocyte $(a-c, i, i)$ and umbilical vein endothelial $(\mathbf{n}, 0)$ cells, as well as on human malignant lung (EPLC 65) (f-h) and bladder (T24) $(j, k, m)$ tumor cells. Visualization of DNA sequences was performed with different detection systems and $(a, b, c-h)$ fluorescence, $(c, d)$ reflection contrast, or (i-a) brightfield microscopy. (a) Doubletarget ISH on a male cell with fluorochirome-labeled alphoid probes for the centromeres of chromosome $X$ in red (rhodamin) and $Y$ in green (FITC); DAPI counterstaining. (b) Triple-target PRINS with centromere specific oligonucleotide primers for the chromosomes 9,7 , and 11 , detected with biotin/blue AMCA (System 7, Figure 2), FluoroRed (dired), and digoxigemin/green FITC (System 1, Figure 2), respectively; aspecific AMCA staining lightly visualizes chromosomes. (c) Single-target ISH with two biotinylated cosmid probes specific for $40 \mathrm{~kb}$ of DNA target on chromosome $11 \mathrm{p} 15$ and $11 \mathrm{q} 23$, detected with System 9 (Figure 2) and the APase-Fast Red reaction (yellow reflection); no counterstaining. (d) Double-target ISH with two centromere-specific probes for the chromosomes 1 and 17, labeled with digoxigenin and biotin, and detected with System 9 (Figure 2)/APase-Fast Red reaction (yellow reflection) and System 2 (Figure 2)MPO-DAB reaction (white reffection), respectively; no counterstaining. (e) Single-target ISH with a biotinylated $40 \mathrm{~kb}$ cosmid probe for chromosome $11 \mathrm{q} 23$, detected with System 9 (Figure 2)/APase-Fast Red reaction; green Thiazole Orange counterstaining. (f) Combined ICC/ISH staining of keratin cytoskeleton with two-steps defection/APase-Fast Red reaction, and centromere 1-specific DNA with green FITClabeled probe; no counterstaining. $(\mathrm{g}, \mathrm{h})$ Combined 1CCASH staining of Ki67-Ag with two-steps detection/APase-Fast Red reaction, and centromere 7-specific DNA with green FITC-labeled probe (g), as well as incorporated BrdU with three-steps blue AMCA detection (h); no counterstaining. (i) Single-target ISH with a biotinylated $40 \mathrm{~kb}$ specific cosmid probe for chromosome $11 \mathrm{q} 23$, detected with System 2 (Figure 2)/PO-DAB reaction; hematoxylin counterstaining. (j) Double-target ISH with a centromere- and a telomere-specific probe for chromosome 1, labeled with biotin and FTTC, and detected with System 6 (Figure 2)/PO-DAB reaction and System 2 (Figure 2)/PO-TMB reaction, respectively; acid inactivation of first detected $\mathrm{PO}$ activity after first $\mathrm{PO}$ reaction; hematoxylin counterstaining. (k) Double-target ISH with two centromere-specific probes for the chromosomes 1 and 7, labeled with digoxigenin and biotin, and detected with System 1 (Figure 2)/APase-Fast Red reaction and System 2 (Figure 2)/APase-ASMX/Fast Blue reaction, respectively; acid inactivation of first detected APase activity after first APase reaction; hematoxylin counterstaining. (1,m) Tripletarget ISH with three centromere-specific probes for the chromosomes 1, 7, and 17, labeled with biotin, digoxigenin, and FITC, and detected with System 6 (Figure 2)/PO-DAB reaction, System 2 (Figure 2)/APase-Fast Red reaction, and Systen 2 (Figure 2)/PO-TMB reaction, respectively; first $\mathrm{PO}$ inactivation as described for $\mathrm{j}$; hematoxylin counterstaining. (n) Combined ICC/ISH staining of the intermediate filament protein vimentin with two-steps detection/blue B-Gal-BCIG reaction, and centromere 1- and 7-specific DNA with, respectively, biotin/System 6 (Figure 2)/PO-DAB reaction and digoxigenin/System 2 (Figure 2)/APase-Fast Red reaction; no counterstaining. (o) Similar staining as seen in wi with the extra detection of the centromere 17-specific DNA with FITC/System 2 (Figure 2)/PO-TMB reaction; first $\mathrm{PO}$ inactivation as described for $\mathrm{j}$; no counterstaining.

References: Specil et al., 1995 (b), 1993 (c,d), $1992 \mathrm{~b}, 1994 \mathrm{a}(\mathrm{e}-\mathrm{h}), 1994 \mathrm{~b}$ (j,1-0).

Magnifications: (a-d), 1200x; $(\mathrm{e}, \mathrm{g}-\mathrm{il}, \mathrm{k}, \mathrm{m}, \mathrm{n}), 600 \mathrm{x} ;(\mathbf{f}, \mathrm{j}, 1,0), 1000 \mathrm{x}$.

PO activity can be realized by a number of different treatments (see Table 3 ). In some cases, it may be better to change the enzyme system used rather than expend effort to remove the endogenous enzyme activity.

\subsection{Detection with brightfield microscopy}

The major advantages of cytochemical detection with enzymes include the stability of the precipitate and thus the possibility to store the cell preparations permanently. The use of a standard brightfield microscope for the analysis is an additional advantage, in particular in a setting where routine analysis have to be performed. In a few cases 

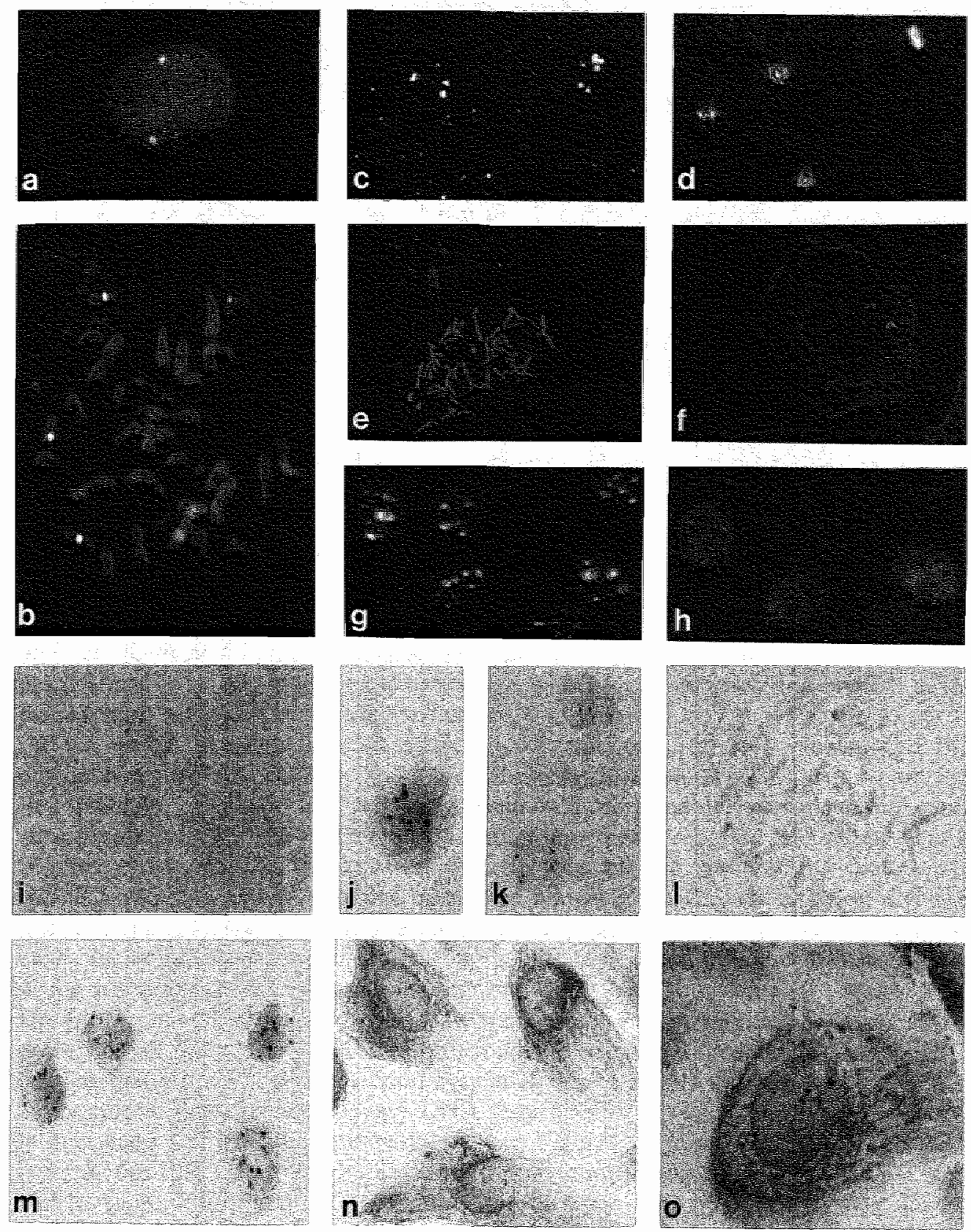


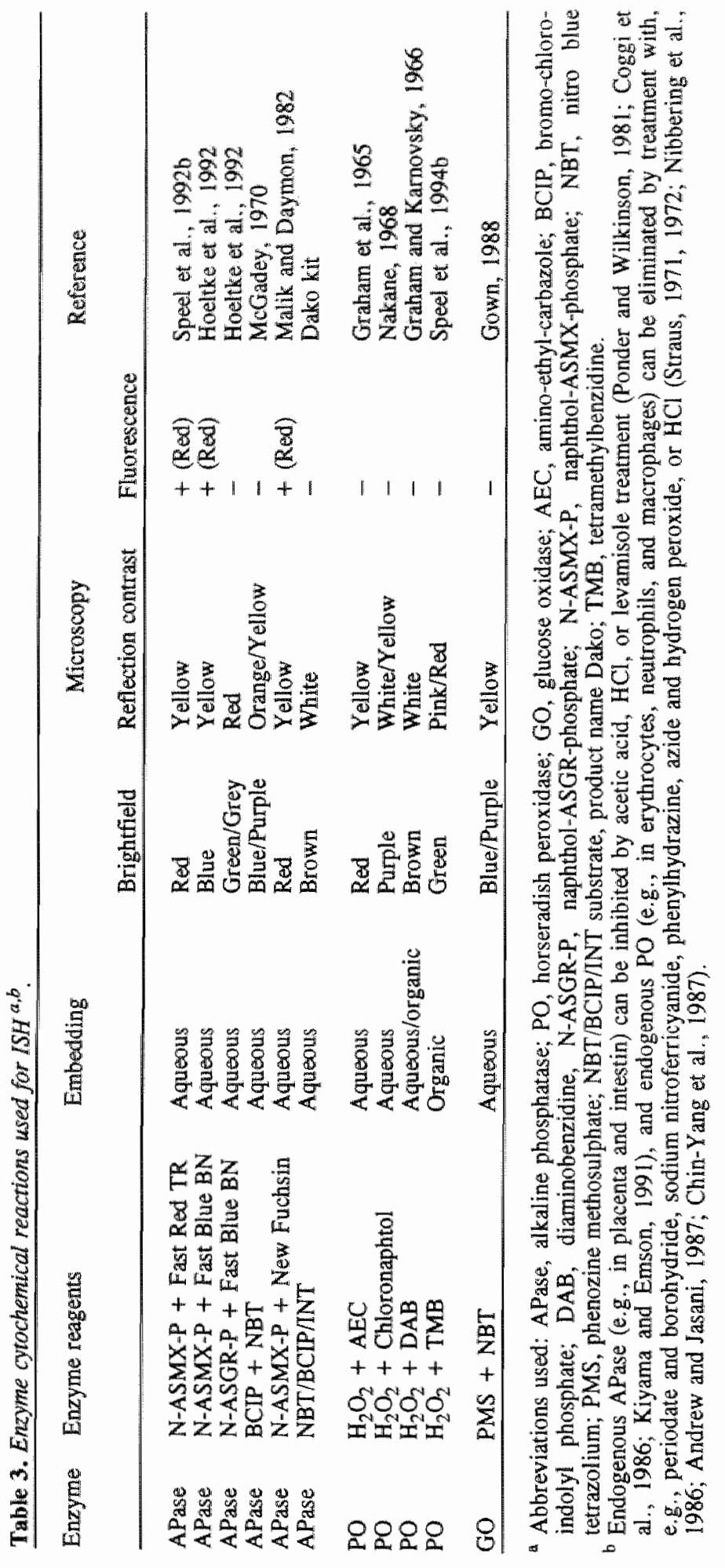


also darkfield microscopy (Heyting et al., 1985) and phase-contrast microscopy (Garson et al., 1987) have been used for visualization of enzyme precipitates after ISH.

The detection of target nucleic acid sequences in situ requires the use of enzyme precipitation reactions that possess both high sensitivity and precize localization properties. Moreover, rapid staining reactions resulting in stable reaction products with contrasting colors are preferred. The criteria used for ISH imply that certain enzymes, commonly used for ICC, are unsuitable for ISH. For example, the localization properties of the B-galactosidase-5-bromo-4-chloro-3-indolyl- $B$-Dgalactoside (B-Gal-BCIG) reaction (Bondi et al., 1982) do not satisfy the conditions needed for ISH, and secondly, the high molecular weight of $B-\mathrm{Gal}(500 \mathrm{kd})$ may be the reason that we have as yet been unable to utilize B-Gal conjugates for ISH (Speel et al., 1994b). In contrast, the enzymes PO (40 kd), APase (100 kd), and glucose oxidase (GO) (185 kd) can be used efficiently for ISH, although the localization properties of GO with the tetrazolium salt methods are not optimal (Speel, personal observation). Table 3 shows the most common possibilities of reagents for these enzymes with the precipitation colors in brightfield microscopy. The enzyme reactions have been described previously (see references in Table 3, and Speel et al., 1993, 1994b). It is recommended to fine-tune the reaction time for each enzyme reaction by monitoring through the microscope. After performing the enzyme reactions, the cell preparations can be lightly counterstained with, e.g., hematoxylin and/or eosin, methylgreen, neutral red, or nuclear fast red.

In our hands, the most appropriate enzyme reactions for ISH include the POdiaminobenzidine (PO-DAB), PO-tetramethylbenzidine (PO-TMB), and APase-Fast Red reaction. Although the APase-5-bromo-4-chloro-3-indolyl phosphate/nitro blue tetrazolium salt (APase-BCIP/NBT) reaction has been reported as very sensitive (Garson et al., 1987), the localization properties of this reaction for ISH do not appear as optimal as the reactions mentioned above. However, reduction of diffusion of the enzyme precipitate from the site of production by means of viscous incubation media including, for example, polyvinyl alcohol has resulted in acceptable localization of the reaction product (Kiyama and Emson, 1991; Van Noorden and Vogels, 1991; De Block and Debrowwer, 1993). This procedure also favoured the localization properties of the APase-Fast Red precipitation reaction (Speel et al., 1992b). In combination with sensitive detection systems, such as Systems 7 and 9 (Figure 2), it is possible to visualize single-copy DNA sequences of $10-40 \mathrm{~kb}$ with high efficiency in interphase and metaphase preparations (see Figure 3i). When the PO-DAB reaction is used, the ISH signal can be enhanced by different intensification methods (Scopsi and Larsson, 1986; Mullink et a]., 1992), of which silver amplification has resulted in the detection of DNA target sequences as small as $1 \mathrm{~kb}$ on metaphase preparations (Manuelides and Ward, 1984; Bhatt et al., 1988). The sensitivity of mRNA detection with enzyme cytochemical detection methods lies in the order of the expression of housekeeping genes (R.W. Dirks, personal communication).

The spatial resolution for brightfield detection is not as high as for fluorescence detection owing to diffusion of the enzyme reaction products during the precipitation 
reaction. Although the spatial resolution for brightfield microscopy with the PO-DAB, PO-TMB, or APase-Fast Red reactions remains to be determined, initial experiments on linear DNA preparations appear to be promising (Speel, unpublished results).

Until recently, only two nucleic acid target sequences could be localized simultaneously in cell and tissue preparations, utilizing PO and APase as the reporter enzymes (Hopman et al., 1986; Emmerich et al., 1989; Herrington et al., 1989; Mullink et al., 1989a; Gentilomi et al., 1992; Kerstens et al., 1994). In these cases, the two contrasting colors of the precipitates could be clearly visualized. It appeared also feasible to combine two APase or PO reactions with each other for double-target ISH (see Figure $3 \mathrm{j}$ and $3 \mathrm{k}$ ), using a mild acid treatment in between to inactivate the first enzyme and thus to avoid mixing of the precipitates during the second enzyme reaction (Speel et al, 1994b). It is recommended to use controls to determine the efficacy of the acid inactivation step, since in some cases a 10 min inactivation can be insufficient (Speel, personal observation). The recent introduction of a modified POTMB reaction for ISH made it possible to develop a relatively fast triple-color ISH method for use in brightfield microscopy (Speel et al., 1994b). For this purpose, a biotin-, digoxigenin-, and FITC-labeled probe can be used in the ISH experiment, which can be detected within three hours with the PO-DAB (brown color), APaseFast Red (red color), and PO-TMB (green color) precipitates (see Protocol 2 (p. 40), and Figure 31 and $3 \mathrm{~m}$ ). To avoid mixing of the precipitates of the two $\mathrm{PO}$ reactions used, again the mild acid treatment could be applied as described above. Furthermore, the cell preparations were embedded in a thin BSA protein layer crosslinked by formaldehyde, which strongly improves color contrast and ensures permanent stabilization of the enzyme reaction products. The precipitating triple-color ISH procedure has proven valuable for the study of chromosome aberrations in tumor cells (Speel et al., 1994b), isolated nuclei from paraffin-embedded, formalin-fixed tissue sections, pre-implantation embryos (E. Coonen, unpublished results), and sperm cells (Martini et al., 1995). The usefulness of this triple staining technique for the visualization of single-copy sequences is currently under study. However, it must be stressed that the distinction between the differently colored reaction products in brightfield microscopy is not always as clear as between different fluorochromes in fluorescence microscopy (see, e.g., Van der Loos et al., 1993), owing to the fact that some enzyme precipitates have a broad absorption spectrum. In this respect, the utilization of specific filters can be beneficial for better color contrast, although in case of small single-copy ISH signals color distinction may be a serious problem. A further extension of colors for brightfield ISH detection could be examined by utilizing colored precipitates that are generated by other PO or APase chromophores (Avivi et al., 1994), such as presented in Table 3, or by combining PO and APase reactions resulting in mixed colors (Claassen et al., 1986; Van der Loos et al., 1993). However, the utility of these efforts for nucleic acid detection in brightfield microscopy is dependent on several factors, including the number of different probe labels and detection protocols that can be applied simultaneously without crossreactivity, the influence of the enzyme inactivation procedures on the stability of the precipitates and nucleic acid probe labels, as well as the color contrast. 


\subsection{Detection with reflection contrast microscopy}

In comparison with brightfield and fluorescence microscopy, the advantage of reflection contrast microscopy ( $\mathrm{RCM}$ ) is the high sensitivity and resolution that can be obtained with the use of specifically localized, non-fading enzyme precipitates that exhibit reflectance properties. Since the enzyme precipitate, the object, and its environment have different reflectance properties, a high-contrast image can be generated (Ploem, 1975). Furthermore, no counterstaining is needed, since unstained cells and tissue sections can be visualized on basis of their dark reflectance. Especially in cases where difficulties arise with recording of faint staining of, e.g.; small nucleic acid target sequences, RCM detection is preferable over brightfield detection. Initial ISH studies were performed with the PO-DAB reaction and resulted in the efficient visualization of DNA targets ranging from repetitive sequences to single-copy genes, and mRNA sequences (Landegent et al., 1985; Ambros et al., 1986; Cornelese-Ten Velde et al., 1988; Multhaupt et al., 1989). However, the application of other enzyme precipitation reactions for RCM detection was hampered by the fact, that most reaction products are only stable in aqueous-based mounting media (see Table 3) and, thus, are unstable in immersion oil, which is required in this procedure. For this purpose, again the application of the thin BSA protein layer (see paragraph 3.1) was found to be useful by preventing the enzyme precipitates from being dissolved in immersion oil. In this way, the specific reflection colors of the different precipitates coulld be observed by RCM (see Table 3, Figure 3c, and Speel et al., 1993). Only the PO-DAB and PO-TMB precipitation products can be embedded directly (without the protein matrix) in immersion oil, since these are stable in an organic-based mounting medium (Table 3 ).

On basis of the use of two enzyme reactions and the application of the BSA protein layer, it proved to be possible to localize two nucleic acid targets simultaneously in the same cell preparation on basis of the reflection colors of the PO-DAB and APaseFast Red precipitates, white and yellow, respectively (see Figure 3d, and Speel et al., 1993). The observed red reflection colors of the PO-TMB and APase-ASGR/Fast Blue precipitates (see Table 3) would be a further improvement for the RCM procedure to be used in three-color detection of nucleic acid targets, as well as the detection of multiple single-copy sequences.

The sensitive RCM technique has its own intrinsic types of artefacts, e.g., dirt particles and small amounts of reaction product that are precipitated as a result of the aspecific binding of cytochemically introduced reagents. These artefacts are rarely seen in brightfield microscopy, but may give rise to interpretative problems during RCM analysis (Speel et al., 1993). Best results are obtained with thin cell preparations and tissue sections, although recently $\mathrm{RCM}$ has also been applied on thick sections (Filler et al., 1994). In addition, the reflectance properties of, e.g., the $\mathrm{PO}-\mathrm{DAB}$ and APase-Fast Blue reaction products are increasingly utilized for examination by CSLM in the reflection mode (Bianco and Boyde, 1989; Robinson and Batten, 1989, 1990; Deitch et al., 1990; Szarowski et al., 1992). However, in those cases no color information is obtained as a consequence of the monochromatic 
laser light. To the best of our knowledge no ISH data are currently available utilizing precipitating enzyme reactions in combination with CSLM in the reflection mode.

\subsection{Detection with fluorescence microscopy}

At present, several APase precipitation reactions have been described to result in fluorescent reaction products (Raap, 1986; Ziomek et al., 1990; Huang et al., 1992; Murray and Ewen, 1992; Kagiyama et al., 1992). However, only two of these reactions have proven to be suitable for use in ISH and are based on the coupling of an enzyme substrate with the diazonium salt Fast Red TR (Larsson and Hougaard, 1991; Harper et al., 1992; Speel et al., 1992b; Kagiyama et al., 1993; see also Table 3). The enzyme reactions result in accurately localized red fluorescent products, enabling the detection of both mRNA and repetitive as well as unique DNA sequences in metaphase and interphase cell preparations. In comparison with the HNP-Fast Red procedure (Kagiyama et al., 1993), the APase-Fast Red procedure described by Speel et al. (1992b) is a rapid staining reaction that produces a precipitate with a virtually permanent character and slow fadling properties. In combination with the APase-Fast Red precipitate, DNA is usually counterstained with blue fluorescent DAPI or a green fluorescent derivative of Thiazole Orange (see Figure 3e, and Speel et al., 1994a, 1994c).

The APase-Fast Red reaction, thus, can be utilized either in brightfield, fluorescence, or reflection contrast microscopy using the same reaction conditions. Optimal results can be achieved by varying the incubation time of this reaction. Detection of mRNA sequences also proved to be feasible with this approach (Larsson and Hougaard, 1991; Harper et al., 1992), although the sensitivity for mRNA detection has not been determined yet. From Table 3 it is clear, that the APase-Fast Blue and APase-New Fuchsin precipitates also show red fluorescent properties. However, these reactions are not recommended for fluorescence detection owing to considerable diffusion of the reaction products. This hampers accurate fluorescence detection, but is, however, not troublesome in brighifield microscopy.

\subsection{Detection with atonic force microscopy}

Only recently it proved to be possible to visualize ISH signals, generated by the PO$D A B$ reaction (in combination with detection system 6, Figure 2), on metaphase preparations by means of atomic force microscopy (AFM) (Putman et all, 1993). This type of microscopy permits the generation of a topographic representation of the sample under investigation with high spatial resolution. Since the PO-DAB precipitate could be distinguished on top of the chromosomes, DNA probes could be detected with a precision of at least $200 \mathrm{~nm}$. Although AFM has been useful for a variety of items in cell biology (Engel, 1991; Hoh and Hansma, 1992), the value of this technique for the detection of single-copy DNA sequences (and DNA mapping) has still to be elucidated. 


\subsection{Chemiluminescence detection}

The enzymes PO and APase have also been utilized in chemiluminescence detection methods with the compounds luminol (Thorpe and Kricka, 1986) or AMPPD (Bronstein et al., 1989), respectively. Although these methods have already been applied in liquid-phase and blotting assays, the application of chemiluminescence for ISH and ICC is hampered by some practical problems, including the efficiency of the photon-collecting system (microscope and CCD camera), the brevity and low intensity of the luminescent signal, the diffusion of the luminescent product, and the coupling of signal detection with morphological information. Hawkins and Cumming (1990) reported the first successful experiments for tissue and cellular viral DNA detection with this method. However, the used detection device gave a signal devoid of morphological information. The use of a photo-collecting system including a microscope with immersion objectives, photomultiplier, and CCD camera together with image processing made it possible to combine chemiluminescent detection of ICC and ISH signals with morphological information (Lorimier et al., 1993). The high sensitivity that could be achieved in ICC and ISH with detection systems 2 and 6 (Figure 2), makes chemiluminescence a promising alternative to fluorescence or brightfield detection. However, more studies will be necessary to determine the ability of this technique to accurately localize enzyme activity in cells and tissue sections.

\section{DETECTION WITH COLLOIDAL GOLD}

Colloidal gold particles are available in different sizes (e.g., 1-20 nm), conjugated to avidin or antibody molecules, and can be visualized at both the light and electron microscopic (EM) level (Geoghegan et al., 1978; Binder et al., 1986; Hoefsmit et al., 1986; Thiry and Thiry-Blaise, 1989; Cornelese-ten Velde and Prins, 1990; Narayanswami and Hamkalo, 1991; Thiry, 1992; Egger et al., 1994; Leitch et al., 1994; Linares-Cruz et al., 1994; Sibon et al, 1994).

Since in most cases gold particles are too small for direct visualization with the brightfield microscope, the detection sensitivity can be increased chemically by silver enhancement (Danscher, 1981; Holgate et al., 1983; Hayat, 1993; Hacker et al., 1994). Colloidal gold catalyses the reduction of silver ions (from silver lactate or silver acetate) to metallic silver using hydroquinone as the reducing agent. Also the shell of metallic silver formed around the gold particle catalyses this reaction, resulting in grey to black deposits when viewed with brightfield microscopy. Silver enhancement exhibits specificity, because it reveals only the colloidal gold label, unless carbon pigments, osmium, metallic gold or silver, or mercury sulfide is present in the tissue, which can act as a catalyst for the reduction of silver ions (Hayat, 1993). In addition, it is not influenced by the presence of endogenous enzyme activities, and promotes accurately localized deposits without diffusion artifacts. However, longer reaction times may lead to conglomerates of silver, owing to 
coalescence of adjacent growing spheres. Therefore, ISH and detection procedures must be optimized to achieve reproducible labeling. For brightfield microscopy, the use of small gold particles (1-10 nm), which result in good access of the conjugates to the nuleic acid probes as well as low repulsion forces between the gold particles, in combination with silver enhancement are preferred for sensitive detection of DNA and mRNA sequences in cells and tissue sections (Hayat, 1993; Hacker et al, 1994). The biological material can be counterstained (see paragraph 3.1) and stored permanently as described above.

Gold particles with or without silver intensification have also been utilized to visualize mRNA as well as antigens in cell preparations and thin tissue sections by means of reflection contrast microscopy (Hoefsmit et al., 1986; Multhaupt et al., 1989; Cornelese-ten Velde and Prins, 1990). In addition, with the use of CSLM in the reflection mode, mRNA transcripts have been localized in cell and tissue preparations utilizing 1-5 nm gold particles with (Van den Brule et al., 1991), or without (LinaresCruz et al., 1994) silver enhancement. Moreover, CSLM allowed the detection of rDNA sequences in plant tissue using $1 \mathrm{~nm}$ gold conjugates and silver enhancement (Rawlins and Shaw, 1990).

At the EM level the highest resolution of signal detection is achieved (in the order of $0.1 \mathrm{~nm}$ ), allowing the visualization of gold particles in association with the fine structure of cells. In general, 5-10 $\mathrm{nm}$ gold-conjugates are mostly used, since they can be visualized directly (Systems 1 or 6, Figure 2), or indirectly (System 2, Figure 2) without the use of silver enhancement (Singer et al., 1989; Narayanswami and Hamkalo, 1991; Thiry, 1992; Dirks et al., 1992; Egger et al., 1994). Smaller gold particles $(0.8-1 \mathrm{~nm})$ are useful if the accessibility of gold conjugates is a problem, but are difficult to visualize at the commonly used $\mathrm{EM}$ magnifications. In that case, silver enhancement methods can be utilized (Narayanswami and Hamkalo, 1991; Bassell et al., 1994; Hacker et al., 1994; Sibon et al., 1994), although it has been reported recently, that silver enhancement of these small gold particles may lead to variations in reproducibility of size and outline of the grains (Egger et al., 1994). The sensitivity of colloidal gold detection is usually lower than for fluorescence or enzyme cytochemical detection, which may be a problem for localizing low-copy or unique nucleic acid sequences.

Using a combination of conjugates with different gold particle sizes, it proved to be feasible to detect different nucleic acid target sequences in the material under study (McFadden et al., 1990; Narayanswami and Hamkalo, 1991; Egger et al., 1994). Furthermore, some degree of quantitation is possible in EM by counting the number of gold particles detecting ISH sites in different cellular areas.

\section{ANALYSIS OF IN SITU HYBRIDIZATION SIGNALS}

The anallysis and counting of ISH signals in cell and tissue preparations can be performed using the different types of microscopy described above, with or without sensitive imaging systems. The maximum sensitivity and spatial resolution depends on 
both the ISH protocol and the visualization method (microscope and imaging system) used. Determination of the requirements needed in one's own ISH experiment (sensitivity, resolution, and number of nucleic acid targets), therefore, is essential prior to choosing the most suitable ISH protocol and visualization method.

Until now, most of the publications on ISH concerned qualitative descriptions. In a number of studies, quantitation has been restricted to counting the number of ISH spots, determination of color composition and signal intensities, and analysis of the relative positions of spots in the nuclei (Hopman et al, 1988b, 1990, 1991; Emmerich et al., 1989; Raap et al., 1989; Dhingra et al., 1994). Although in this way a clear impression can be obtained of, e.g., the chromosome aberrations in a tumor sample, the acquisition of these data is influenced by a number of factors, i.e., the quality of the material under study, hybridization efficiency, properties of the cytochemical detection reagents, microscopical instrumentation features, and interobserver variations. Therefore, statistical analysis as well as advanced microscopic and optical instrumentation in combination with (semi)automated image analysis will be more and more required to further improve the sensitivities, specificities, and reproducibility of ISH applications, such as rare event detection (Nederlof et al., 1992; Kibbelaar et al., 1993; Celeda et al., 1994; Carothers, 1994). For this purpose, sensitive CCD camera systems may be used, which can record fluorescent ISH signals as small as single-copy genes over a wide spectral range during variable periods of time (Lichter et al., 1991; Ried et al., 1992; Wiegant et al., 1993). ISH signals do not have to be greatly amplified to enable visualization, which will result in higher specificity and resolution. Furthermore, recorded images can be further processed to eliminate out-of-focus (and background) information, to change contrast and intensity of signals, to assign artificial colors to different signals, to compare different recorded images, and to measure ISH signal sizes and intensities. Also for analysis of enzyme cytochemically produced ISH signals, advanced instrumentation is under way.

ISH results can also be analyzed by flow cytometry, enabling the rapid quantification of fluorescence intensity resulting from ISH of modified probes to DNA or mRNA target sequences in large amounts of cells, nuclei, or chromosomes in suspension (Trask et al., 1985; Bauman et al., 1989; Bayer and Bauman, 1990; Van Dekken et al., 1990a). Although in this way no information about the arrangement or localization of the hybridrzed probe can be obtained, the rapid flow cytometric analysis of ISH signals can be advantageous for diagnostic purposes, for example to relate the presence of chromosome aberrations with abnormal nuclear DNA content in individual nuclei (Kwak et al., 1994).

CSLM can be of value in cases where ISH signals lie in different focal planes within cell or tissue preparations, or the image is disturbed with autofluorescence and/or outof-focus information. Furthermore, optical sectioning through biological material has been used to generate three-dimensional images of the distribution of ISH signals in the specimen (Van Dekken et al., 1990b; Zirbel et al., 1993; Ikizyan et al., 1994). 


\section{COMBINATION OF IMMUNOCYTOCHEMISTRY AND IN SITU HYBRIDIZATION}

With immunocytochemistry (ICC), specific information can be obtained regarding the presence or absence of proteins or antigens in cells and tissue sections, thus allowing the detection of different types of cellular differentiation. Furthermore, the proliferative activity of cells can be determined by means of, e.g., incorporated bromodeoxyuridine ( $\mathrm{BrdU}$ ) detection. In many instances, however, it would be advantageous to combine the results of ICC and ISH to examine the relationship between genetic and phenotypic parameters in the same biological material. Although this can be achieved by comparing the results of ICC and ISH carefully on serial sections, there are now a variety of protocols available to combine ICC and ISH efficiently on the same cell preparation or tissue section. The first procedures described made use of radioactive ISH probes and tissue fixed and embedded according to sophisticated procedures (Brahic et al., 1984; Gendelman et al., 1985; Wolfson et al., 1985; Shivers et al., 1986). At present, fast non-radioactive procedures have been developed to demonstrate simultaneously the presence of mRNA and its protein product in one cell (Larsson and Hougaard, 1991; Harper et al., 1992; Dirks et al., 1993; Heppelmann et al., 1994), to immunophenotype cells containing a specific chromosomal aberration or viral infection (Porter et al., 1990; Losada et al., 1991; Van den Berg et al., 1991; Kibbelaar et al., 1992; Strehl and Ambros, 1993; Weber-Matthiesen et al., 1993a, 1993b; Zheng et al., 1993; Bridge et al., 1994; Herbergs et al., 1994; Leger et al., 1994; Robben et al., 1994; Speel et al., 1994a, 1994b), or to determine cytokinetic parameters of tumor cell populations that are genetically or phenotypically aberrant (Schutte et al., 1987; Balazs et al., 1991; Van Dekken et al., 1991; Ffrench et al., 1994; Speel et al., 1994a).

A successful combination of ICC and non-radioactive ISH requires several factors to be satisfied, such as preservation of cell morphology and protein epitopes, accessibility of nucleic acid targets, no cross-reaction between the different detection procedures, and good color contrast and stability of enzyme cytochemical precipitates and fluorochromes. All these factors determine the success rate and sensitivity of the procedure. Since several steps in the ISH procedure, including enzymatic digestion, post-fixation, denaturation at high temperatures, and hybridization in formamide, may destroy antigenic determinants, a procedure starting with ICC and followed by ISH is preferred in most cases. A variety of such combined ICC/ISH procedures have been reported now using either enzyme precipitation reactions (Mullink et al., 1989b; Van der Loos et al., 1989; Porter et al., 1990; Van den Brink et al., 1990; Graham et al., 1991; Losada et al., 1991; Robben et al., 1994; Speel et al., 1994b), fluorochromes (Van den Berg et al., 1991; Kibbelaar et al., 1992; Weber-Matthiessen et al., 1993a, 1993b; Bridge et al., 1994; Leger et al., 1994), or a combination of both (Strehl and Ambros, 1993; Zheng et al., 1993; Herbergs et al., 1994; Speel et al., 1994a). The procedures can be subdivided into two groups, using either fluorochromes or enzyme reactions for ICC. 
Fluorochromes have been used mainly on acetone-fixed cell preparations, since the material can be mildly post-fixed after detection of the antigen (usually with paraformaldehyde) and used directly for fluorescence ISH without any further pretreatment steps (Weber-Matthiessen et al., 1993a; Bridge et al., 1994; Leger et al., 1994). However, often amplification steps for both ICC and ISH signals are necessary for clear visualization. In these procedures, enzymatic pre-treatment after ICC has shown to be disadvantageous, since such a step destroys fluorescent ICC staining dramatically (Speel et al., 1994a). In one case this combined fluorescence ICC/ISH procedure could be used on cryostate sections (Weber-Matthiessen et al., 1993c).

Enzyme precipitation reactions have also been used efficiently for staining of proteins in combined ICC/ISH procedures on cell preparations and tissue sections. Enzyme precipitation products that withstand the proteolytic digestion and denaturation steps used in the ISH procedure, include the APase-Fast Red (Zheng et al., 1993; Herbergs et al., 1994; Speel et al., 1994a, 1994c), APase-New Fuchsin (Mullink et al., 1989b; Porter et al., 1990), APase-BCIP/NBT (Graham et al., 1991), PO-DAB (Mullink et al., 1989b; Van der Loos et al., 1989; Strehl and Ambros, 1993), and B-Gal-BCIG (Van den Brink et al., 1990; Robben et al., 1994; Speel et al., 1994b) precipitates. In these cases the digestion and denaturation steps of the ISH procedure remove the antibody and enzyme detection layers, but the precipitate remains firmly localized. Hence, unwanted cross-reaction between the detection procedures for ISH and ICC is prevented. However, appropriate controls should be incorporated to ensure that this is the case.

Antigen staining with the APase-Fast Red reaction has the advantage that a sensitive and high-resolution fluorescence approach can be used for both ICC and ISH on cell preparations and tissue sections (Zheng et al., 1993; Herbergs et al., 1994; Speel et al., 1994a, 1994c). This enzyme precipitate could be accurately localized, proved to be resistant to enzymatic pretreatment steps and to be stable during the entire ISH procedure (see Figure 3f). Protocol 3 (p. 42) shows the steps necessary in a procedure combining the cellular localization of one protein with APase-Fast Red with two DNA targets detected by FITC and AMCA (Speel et al., 1994a). Instead of two DNA targets, it proved also feasible to localize a cellular antigen together with one DNA target and incorporated BrdU, which makes it possible to assess phenotypic, genotypic, and cell cycle parameters in one cell (see Figure $3 \mathrm{~g}$ and $3 \mathrm{~h}$, and Speell et al., 1994a). Fluorescence ISH has also been combined with the PO-DAB reaction for ICC (Strehl and Ambros, 1993). However, the PO-DAB precipitate has been shown to make cells less accessible to ISH reagents and to shield the target DNA (Van der Loos et al., 1989; Strehl and Ambros, 1993). Therefore, we advise to fine-tune the ICC staining reaction always to ensure proper $\mathbb{I S H}$ results.

The triple-color ISH detection procedure for brightfield microscopy (see Protocoll 2, p. 40) can also be combined with ICC utilizing the B-Gal-BClG reaction in advance (Speel et al., 1994b). In this case, an antigen is localized with B-Gal-BCIG cytochemistry (Bondi et al., 1982), followed by proteolytic digestion as described in Protocol 3. After the post-fixation step and ISH with a biotin-, digoxigenin-, and FITC-labeled probe, then Protocol 2 can be performed (see Figure 30). However, 
since the color contrast between the blue $B-G a l-B C I G$ and green $P O-T M B$ reaction product is relatively low, a combination with PO-DAB and APase-Fast Red is recommended (see Figure 3n, and Speel et al., 1994b).

In several cases where mRNA targets have been detected simultaneously with proteins, the material under study is first pre-treated with proteolytic enzymes, then subjected to ISH, and finally to ICC (Larsson and Hougaard, 1991; Harper et al., 1992; Dirks et al., 1993; Trembleat et al., 1993; Heppelmann et al., 1994). This is only effective if the antigenic determinants are preserved during the pretreatment steps and ISH procedure. An advantage of this sequence of treatments is the elimination of the risk of possible RNase activity which might be present in the reagents used for ICC. In case the ICC has to be performed prior to ISH, protection of target mRNAs with RNase inhibitors such as diethylpyrocarbonate appeared to be necessary to prevent RNA degradation (Shivers et al., 1986). At present, fluorescence, enzyme cytochemical, as well as colloidal gold-based procedures have been described to efficiently combine mRNA ISH and ICC on cell preparations and tissue sections (Singer et al, 1989; Larsson and Hougaard, 1991; Harper et al., 1992; Dirks et al., 1992, 1993; Bassell et al., 1994; Egger et al., 1994; Heppelmann et al., 1994; Sibon et al., 1994).

\section{CONCLUDING REMARIKS AND FUTURE PROSPECTS}

This review describes the currently available non-radioactive ISH detection methodologies as well as procedures for simultaneous localization of proteins, nucleic acids and/or incorporated BrdU in cell and tissue preparations. Table 4 summarizes the similarities and differences between the ISH detection methodologies. Despite the standard differences between the fluorescence and brightfield approaches and the occurring preferences with which these approaches are applied in the various research areas (e.g., fluorescence ISH in cytogenetics, and enzyme cytochemical and/or goldsilver detection in pathology), in principle every system enables visualization of DNA sequences up to the level of cosmid-sized single-copy probes in most types of biological material when using optimal detection protocols. Even the localization of unique target sequences in the range of $1-5 \mathrm{~kb}$ on metaphases has been achieved with enzyme cytochemical detection protocols (Garson et al., 1987; Bhatt et al., 1988), although mostly fluorescence approaches in combination with $\mathrm{CCD}$ recording and image analysis are being used for this purpose. On tissue sections, however, this sensitivity may not be reached with the current methodologies, owing to factors such as accessibility and loss of target DNA, which determine the detection limit of ISH. As a consequence, protocols have to be further optimized and new detection and amplification techniques must be developed to reach higher sensitivities and detection efficiencies. This may also lead to improvement of the detection limit on chromosomes and linear DNA below the level of $1 \mathrm{~kb}$. In this respect a number of potential developments are of interest, including the design of antibody- or avidinpolymer molecule complexes which contain more fluorochromes or enzymes as 


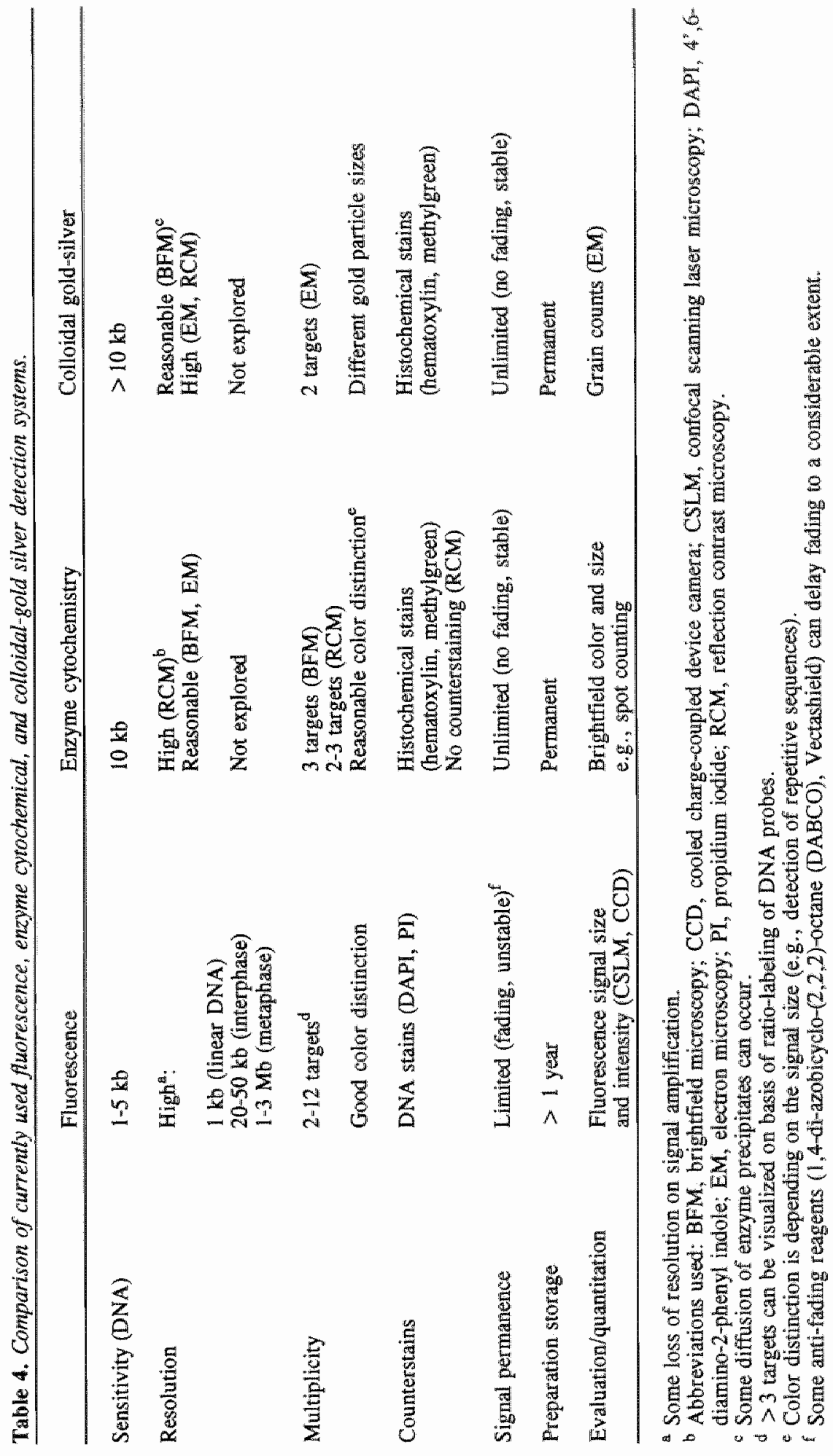


compared to the usual detection conjugates (e.g., EPOS reagents from Dako, Glostrup, Denmark), the in situ polymerase chain reaction (in situ PCR), and the catalyzed reporter deposition (CARD) system.

To achieve higher amounts of reporter molecules (fluorochromes or enzymes) at the site of hybridization, polymer molecules such as dextran sulphate or DNA are currently being utilized to couple both reporter and avidin or antibody molecules. In this way, highly flexible reagents are obtained that contain many reporter molecules and have the capacity to bind directly or indirectly to nucleic acid probes. Although initial experiments with these reagents are promising, it remains to be seen if lower detection limits will be achieved.

In situ PCR, originally introduced by Haase et al. (1990), combines the properties of the PCR technique with ISH, permitting the localization of specific amplified DNA or RNA sequences within isolated cells and tissue sections (Chiu et al., 1992; Nuovo, 1992; Komminoth and Long, 1993). Theoretically, the method of in situ PCR is straightforward: fixation of cells or tissue, permeabilization of cell membranes allowing the primers and enzymes to enter the cell but avoiding the loss of the generated amplificants, intracellular PCR amplification, and direct or indirect (by ISH) detection of the amplificants. The practical procedure, however, appears to present several problems, including a relatively low and variable amplification efficiency, false positivity due to mispriming, diffusion of PCR products, extracellular generation of amplificants, and variation in the results of different detection procedures, resulting in restricted specificity and sensitivity and relative poor cell morphology (Höfler, 1993; Komminoth and Long, 1993). Nevertheless, several groups have reported the amplification and visualization of single-copy DNA sequences in cells and tissue sections with this approach (Nuovo, 1992; Komminoth and Long, 1993). Especially the recently described retainment of amplification products on metaphase chromosomes is at least remarkable (Gosden and Hanratty, 1993; Terkelsen et al., 1993; Troyer et al., 1994) and may lead to more optimal in situ PCR protocols with a high sensitivity and localization specificity.

The CARD amplification system, introduced by Bobrow et al. (1989) and applied to immunoassays and ICC (Bobrow et al., 1989, 1991; Adams, 1992), is based on deposition of biotinylated tyramine (BT) by the activity of PO. Thus, if PO-conjugates are tutilized to detect a specific nucleic acid sequence or antigen, BT can be accumulated in large amounts and can, subsequently, be visualized with avidin or anti-biotin molecules conjugated to enzymes, fluorochromes, or gold particles. The first results already demonstrate that the ISH detection limit for fluorescence and brightfield microscopy can be further increased (Kerstens et al., 1995; Raap et al., 1995). Furthermore, higher detection efficiencies can be reached even for small single-copy probes. The CARD system, therefore, seems to have many promising possibilities, including a further increase of the DNA and mRNA detection sensitivity on all types of biological material, as well as the extension to multiple-target ISH. Although extensive enzymatic signal amplifications will influence resolution, the impact of the CARD system could be considerable in molecular cytogenetics and pathology. 
With respect to resolution it is generally accepted that electron microscopy provides the highest resolving power (in the order of $0.1 \mathrm{~nm}$ ), which makes it possible to localize nucleic acid sequences at the subcellular level. However, the ISH detection sensitivity in EM is still too low compared with the light microscopical procedures. Other ways to obtain a high resolution comprise the use of other types of microscopy (e.g., atomic force microscopy) or the production of linear DNA fibers. The latter methods can yield resolutions of $1 \mathrm{~kb}$ approaching the $0.32 \mu \mathrm{m}$ length of $1 \mathrm{~kb}$ in the Watson-Crick DNA double helix model. The increase in resolution, using these linear DNA preparations, does, however, imply that information about the topography of genes and their transcripts in the cell is lost. Although these methods will have wide applications in gene mapping and DNA diagnosis (e.g., Tocharoentanaphol et all, 1994), increased resolution will still be needled to enable three-dimensional studies of chromatin organization. The most obvious difference between the different detection methodologies summarized in Table 4 is the advantage of the fluorescence approaches to detect up to 12 DNA targets simultaneously, whereas the other procedures have been able to detect up to maximally three different targets. This has been the result of a number of factors, including the possibility to spectrally separate fluorochromes (AMCA, FITC, Texas Red) almost completely in the fluorescence microscope, the use of single-, double-, or ratio-labeled probes, the introduction of high-transmission multiple bandpass filters for the simultaneous visualization of blue, green, and red fluorescence without image shifts, and the development of digital cameras and image analysis software to discriminate between the different ISH signals. The infra-red emitting fluorochrome Cy5 can possibly contribute to a further increase of the multiplicity of fluorescence detection. On the contrary, the often broad absorption spectra of enzyme precipitates limit the number of targets that can be visualized simultaneously in brightfield microscopy to three or four. Furthermore, small nucleic acid targets will still be difficult to detect on basis of brightfield color contrast. However, if it becomes possible to implement the amplification systems described above in these enzyme cytochemical detection methodologies, triple-target ISH with repetitive as well as small, single-copy probes will become a valuable tool for the diagnostic analysis of numerical and structural chromosomal aberrations in a routine setting.

The rapid developments in cell cycle research, the identification of important cancer genes, and the unraveling of regulation processes that occur in embryonic development and differentiation of cells, make it more and more interesting to study the presence or absence of genes, gene transcripts, and proteins, as well as their nuclear and/or cytoplasmic topography. The described procedures, combining ISH and ICC, already demonstrate the possibilities to visualize multiple parameters at the single cell level. Therefore, it will be a challenge to further develop these combined procedures allowing, for example, the simultaneous localization of a gene, its transcript, and its protein in one cell. These combined ICC/ISH procedures will provide us with new information on the dynamics of molecular processes occurring in the cell. 


\section{E. PROTOCOLS}

Protocol 1. Fluorescence detection of three DNA target sequences hybridized with a biotin-, digoxigenin-, and FTC-labeled DNA probe in cell preparations.

Reagents:

Buffer A:

Buffer B:

Buffer C:

Buffer D:

AVAMCA:

BIOGAA:

MADig:

RAFITC:

ShAMDig:

SWARFTTC:

ShADIg-TRITC:

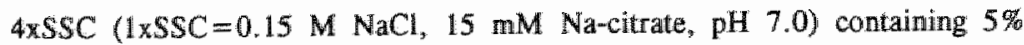
non-fat dry milk.

$4 \times$ SSC containing $0.05 \%$ Tween 20 .

PBS $(0.15 \mathrm{M} \mathrm{NaCl}, 10 \mathrm{mM}$ sodium phosphate, pH 7.2) containing $0.05 \%$ Twween 20.

Buffer $\mathrm{C}$ containing $2 \%$ normal goat serum.

Anti-fade medium

AMCA-conjugated avidin (Vector, Brunschwig Chemie, Amsterdam, The Netherlands), diluted 1:100.

Biotinylated goat anti-avidin (Vector), diluted $1: 100$.

Mouse antimdigoxin (Sigma, St. Louis, MO, USA), diluted 1:2000.

Rabbit anti-FITC (Dako, Glostrup, Denmark), diluted 1:2000.

Digoxigenin-conjugated sheep anti-mouse IgG (Boehringer, Mannheim. Germany), diluted $1: 100$.

FITC-conjugated swine anti-rabbit IgG (Dako), diluted 1:100.

TRITC-conjugated sheep anti-digoxigenin (Boehringer), diluted 1:100.

$0.2 \mathrm{M}$ Tris-HCl, $\mathrm{pH} 7.6$ :glycerol $(1: 9$, w/v) containing $2 \% 1,4$-di-azobicyclo$(2,2,2)$-octane (DABCO; Sigma).

-
-
-
-
-
-
-
-
-

After ISH and washing steps block with Buffer A

Wash with Buffer $B$

AvAMCA diluted in Buffer A

Wash with Buffer B

Wash with Buffer C

BioGAA/MADIg/RAFITC diluted in Buffer D

Wash with Buffer C

AvAMCA/ShAMDig/SWARFITC diluted in Buffer $D^{\text {a }}$

Wash with Buffer $C^{6}$

ShADig-TRITC diluted in Buffer D

Wash with Buffer C

Wash with PBS

Mount in anti-fade medium withoutt a counterstain and store at $4^{\circ} \mathrm{C}$

10 min, $37^{\circ} \mathrm{C}$

$1 \mathrm{~min}, \mathrm{RT}$

$20 \min , 37^{\circ} \mathrm{C}$

$5 \mathrm{~min}, \mathrm{RT}$

$5 \mathrm{~min}, \mathrm{RT}$

$30 \mathrm{~min}, 37^{\circ} \mathrm{C}$

$2 \times 5$ min, $R T$

$30 \mathrm{~min}, 37^{\circ} \mathrm{C}$

$2 \times 5$ min, RT

$30 \mathrm{~min}, 37^{\circ} \mathrm{C}$

$2 \times 5 \mathrm{~min}, \mathrm{RT}$

$5 \min , \mathrm{RT}$

"ShAMDig can be substituted by TRITC-conjugated goat anti-mouse IgG (GAMTRITC, diluted 1:100; Dako)\%, if the target size is large enough (strong fluorescence signal).

b After this step an optional amplification can be performed following step 6-9 for the second time.

Protocol 2. Enzyme cytochemical detection of three DNA target sequences hybridized with a biotin digoxigenin-, and FITC-labeled DNA probe in cell preparations.

Reagents:

Buffer A-D: $\quad$ see Protocol 1.

AvPO: $\quad$ PO-conjugated avidin (Dako), diluted 1:50.

MADig: see Protocol 1.

RAFITC: $\quad$ see Protocol 1.

GAMAPase: APase-conjugated goat anti-mouse IgG (Dako), diluted 1:25.

SWARPO: $\quad$ PO-conjugated swine anti-rabbit $\lg G$ (Dako), diluted 1:100. 
- After ISH and washing steps, block with Buffer A

Wash with Buffer B

AvPO diluted in Buffer $A$

Wash with Buffer B

Wash with PBS

Detection of $\mathrm{PO}$ activity in brown (PO-DAB)

Inactivation of $A v P O$ rest activity with $0.01 \mathrm{~N} \mathrm{HCl}$

Wash with Buffer C

MADig/RAFTTC diluted in Buffer D

Wash with Buffer C

GAMAPase/SWARPO dihted in Buffer D

Wash with Buffer C

Wash with PBS

Detection of APase activity in red (APase-Fast Red)

Detection of $\mathrm{PO}$ activity in green (PO-TMB)

Counterstain with haematoxylin

Air-dry

Smear slides with $20 \mathrm{mg} / \mathrm{ml} \mathrm{BSA}$ in $2 \%$ formaldehyde and air-dry

Mount slides in aqueous- or organic-based medium and store at $4^{\circ} \mathrm{C}$
$10 \min _{3} 37^{\circ} \mathrm{C}$

1 min, RT

$20 \mathrm{~min}, 37^{\circ} \mathrm{C}$

$2 \times 5$ min, RT

$5 \mathrm{~min}, \mathrm{RT}$

$5-15 \mathrm{~min}, 37^{\circ} \mathrm{C}$

$10 \mathrm{~min}, \mathrm{RT}$

$11 \mathrm{~min}, \mathrm{RT}$

30 min, $37^{\circ} \mathrm{C}$

$2 \times 5 \mathrm{~min}, \mathrm{RT}$

$30 \mathrm{~min}, 37^{\circ} \mathrm{C}$

$2 \times 5$ min, RT

$5 \mathrm{~min}, \mathrm{RT}$

$5-15 \mathrm{~min}, 37^{\circ} \mathrm{C}$

$1-2 \min , 37^{\circ} \mathrm{C}$

$10 \mathrm{~min}, \mathrm{RT}$

$10 \mathrm{~min}, 37^{\circ} \mathrm{C}$

Enzyme reactions:

PO-DAB:

- Mix just before use: $\quad$ - $1 \mathrm{ml} \mathrm{3,3}$ diaminobenzidine tetrachloride (DAB; Sigma) in PBS (5 $\mathrm{mg} / \mathrm{ml}$ stock)

- $9 \mathrm{ml}$ PBS/0.1. M imidazole, pH 7.6

- $10 \mu \mathrm{l} 30 \% \mathrm{H}_{2} \mathrm{O}_{2}$

- Incubate slides with $100 \mu l$ under a coverslip for $5-15$ min at $37^{\circ} \mathrm{C}$

- Wash $3 \times 5$ min with PBS

APase-Fast Red:

Mix just before use: $\quad-4 \mathrm{ml} 0.2 \mathrm{M}$ Tris- $\mathrm{HCl}, \mathrm{pH} 8.5$, containing $10 \mathrm{mM} \mathrm{MgCl}$ and $5 \%$ polyvinyl alcohol (PVA, MW 40,000; Sigma)

- $250 \mu \mathrm{l}$ buffer without PVA containing $1 \mathrm{mg}$ naphthol-ASMXphosphate (Sigma)

- $750 \mu$ buffer without PVA containing $5 \mathrm{mg}$ Fast Red TR salt (Sigma)

Incubate slides with $100 \mu \mathrm{l}$ under a coverslip for $5-15$ min at $37^{\circ} \mathrm{C}$

Wash $3 \times 5$ min with PBS

PO-TMB:

- Dissolve $100 \mathrm{mg}$ sodium tungstate (Sigma) in $7.5 \mathrm{ml} 100 \mathrm{mM}$ citrate-phosphate buffer pH 5.1 and bring back the $\mathrm{pH}$ afterwards to $\mathrm{pH} 5.0-5.5$ with $37 \% \mathrm{HCl}$

Dissolve just before use, respectively, $20 \mathrm{mg}$ dioctyl sodium sulfosuccinate (Sigma) and $6 \mathrm{mg}$ $3,3^{*}, 5,5^{*}$-tetramethylbenzidine (TMB, Sigma) in $2.5 \mathrm{ml} 100 \%$ ethanol at $80^{\circ} \mathrm{C}$

Mix both solutions and add $10 \mu 130 \% \mathrm{H}_{2} \mathrm{O}_{2}$

Incubate slides with $100 \mu$ under a coverslip for $1-2$ min at $37^{\circ} \mathrm{C}$

Wash $3 \times 1$ min with ice-cold $0.1 \mathrm{M}$ phosphate buffer pH 6.0 
Protocol 3. Combined fluorescence ICC/ISH procedure for the detection of one antigen with the APase-Fast Red reaction and two DNA target sequences with FITC-and biotin-labeled DNA probes in cell preparations.

Reagents:

Buffer A-B: $\quad$ see Protocol 1

AvAMCA: $\quad$ see Protocol 1

BioGAA: see Protocol 1

- Fix cells in methanol $\left(5 \mathrm{sec},-20^{\circ} \mathrm{C}\right)$ and acetone $\left(3 \times 5 \mathrm{sec}, 4^{\circ} \mathrm{C}\right)$, and tissue sections in methanol $\left(1 \mathrm{~min},-20^{\circ} \mathrm{C}\right)$ and acetone $(3 \times 5 \mathrm{sec}, \mathrm{RT})^{\mathrm{a}}$

Perform ICC with a two- or three-steps APase detection procedure ${ }^{b}$

- Detection of APase activity in red (APase-Fast Red) ${ }^{c}$

Wash with $0.01 \mathrm{~N} \mathrm{HCl}$

Digest with $100 \mathrm{\mu g} / \mathrm{ml}$ pepsin (Sigma) in $0.01 \mathrm{~N} \mathrm{HCl}$

Wash with $0.01 \mathrm{~N} \mathrm{HCl}$

Wash with PBS

Post-fix with $1 \%$ paraformaldehyde in PBS

Wash with PBS

Wash with $2 \times S S C$

$5-15 \min , 37^{\circ} \mathrm{C}$

$2 \mathrm{~min}, 37^{\circ} \mathrm{C}$

$10-20 \mathrm{~min}, 37^{\circ} \mathrm{C}$

$2 \min , 37^{\circ} \mathrm{C}$

$1 \mathrm{~min}, \mathrm{RT}$

$20 \mathrm{~min}, 4^{\circ} \mathrm{C}$

$5 \mathrm{~min}, \mathrm{RT}$

$5 \mathrm{~min}, \mathrm{RT}$

Perform ISH with a FITC - and a biotin-labeled DNA probed

After ISH and washing steps, block with Buffer A

Wash with Buffer B

AvAMCA diluted in Buffer $A^{\circ}$

Wash with Buffer $B$

BioGAA diluted in Buffer A

Wash with Buffer B

AvAMCA diluted in Buffer A

Wash with Buffer $B$

Wash with PBS

Mount in anti-fade medium without a counterstain and store at $4^{\circ} \mathrm{C}^{\mathrm{f}}$

$10 \mathrm{~min}, 37^{\circ} \mathrm{C}$

$1 \mathrm{~min}, \mathrm{RT}$

$20 \mathrm{~min}, 37^{\circ} \mathrm{C}$

$2 \times 5$ min, RT

$20 \mathrm{~min}, 37^{\circ} \mathrm{C}$

$2 \times 5 \mathrm{~min}, \mathrm{RT}$

$20 \mathrm{~min}, 37^{\circ} \mathrm{C}$

$2 \times 5$ min, RT

$5 \mathrm{~min}, \mathrm{RT}$

"If methanol destroys the antigen, a fixation with only acetone is recommended (Mullink et al., 1989b).

We recommend Systems 2 or 7 as shown in Figure 2.

- As described in Protocol 2.

¿See Speel et all., 1993, 1994a.

- In case the FITC ISH signals are to weak, they can be amplified by using mouse anti-FITC (diluted $1: 500$ in Buffer D (Protocol 1); Dako) or rabbit anti-FITC (diluted 1:2000 in Buffer D (Protocol 11): Dako) and a FITC-conjugated secondary antibody (see System 2, Figure 2). Cross-reaction with the ICC detection layers does not occur, since the pepsin digestion is thought to destroy these layers to a large extent.

As described in Protocol 1.

\section{Acknowledgements}

This work was supported by the Netherlands Organization for Scientific Research NWO, grant no.
900-534-102. 


\section{REFERENCES}

Adams JC (1992) Biotin amplification of biotin and horseradish peroxidase signals in histochentical stains. J Histochem Cytochem 40:1457-1463

Ambros PF, Matzke MA, Matzke AJM (1986) Detection of a 17 kb unique sequence (T-DNA) in plant chromosomes by in situ hybridization. Chromosoma $94: 11-18$

Amersham (1993) In situ hybridization. A guide to radioactive \& non-radioactive in situ hybridization systems. Amersham International, Little Chal font

Andrew SM, Jasani B (1987) An improved method for the inhibition of endogenous peroxidase nondeleterious to lymphocyte surface markers. Application to immunoperoxidase studies on eosinophil rich tissue preparations. Histochem J 19:426-430

Avivi C, Rosen O, Goldstein S (1994) New chromogens for alkaline phosphatase histochenistry: salmon and magenta phosphate are useful for single- and double-label immunohistochemistry. $\mathrm{J}$ Histochem Cytochem 42:551-554

Bains MA, Agarwal R, Pringle JH, Hutchinson RM, Lauder I (1993) Flow cytometric quantitation of sequence-specific mRNA in hemopoietic cell suspensions by primer-induced in situ (PRINS) fluorescent nucleotide labeling. Exp Cell Res 208:321-326

Ballazs M, Mayall BH, Waldman FM (1991) Simultaneous analysis of chromosomal aneusomy and 5bromodeoxyuridine incorporation in MCF-7 breast tumor cell line. Cancer Genet Cytogenet 57:93 102

Bassell GJ, Powers CM, Taneja KL, Singer RH (1994) Single mRNAs visualized by ultrastructural in situ hybridization are principally localized at actin filament intersections in fibroblasts. $J$ Cell Biol $126: 863-876$

Bauman JGJ, Wiegant J, Borst P, Van Duijn P (1980) A new method for tluorescence microscopical localization of specific DNA sequences by in situ hybridization of fluorochrome-labelled RNA. Exp Cell Res 128:485-490

Bauman JGJ, Pinkel D, Trask BJ, Van der Ploeg M (1989) Flow cytometric measurement of specific DNA and RNA sequences. In Gray JW (eds): Flow cytogenetics. London, Academic Press, pp 275301

Bayer $\mathbb{I A}$, Bauman $\mathbb{J} G J$ (1990) Flow cytometric detection of $\beta$-globin mRNA in murine hemopoietic tissues using fluorescent in situ hybridization. Cytometry 11:132-143

Beverloo HB, Van Schadewijk A, Van Gelderen-Boele S, Tanke HJ (1990) Inorganic phosphors as new luminescent labels for immunocytochemistry and time-resolved microscopy. Cytometry 11:784792

Bhatt B, Burns J, Flannery D, McGee JO'D (1988) Direct visualization of single copy genes on banded metaphase chromosomes by nonisotopic in situ hybridization. Nucleic Acids Res 16:39513961

Bianco P, Boyde A (1989) Alkaline phosphatase cytochemistry in confocal scanning light microscopy for imaging the bone marrow stroma. Bas Appl Histochem 33:17-23

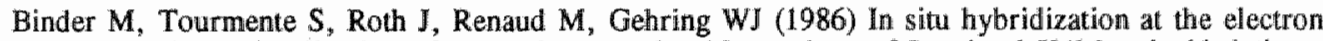
microscope level: localization of transcripts on ultrathin sections of Lowicryl $\mathrm{K} 4 \mathrm{M}$-embedded tissue using biotinylated probes and protein A-gold complexes. J Cell Biol 102:1646-1653 
Bobrow MN, Harris TD, Shaughnessy KJ, Litt GJ (1989) Catalyzed reporter deposition, a novel method of signal amplification. Application to immunoassays. J Immunol Methods 125:279-285

Bobrow MN, Shaughnessy KJ, Litt GJ (1991) Catalyzed reporter deposition, a novel method of signal amplification. I Immunol Methods 137:103-112.

Böck $G$, Hilchenbach $M$, Schauenstein $K$, Wick $G$ (1985) Photometric analysis of antifading reagents for immunofluorescence with laser and conventional illumination sources. J Histochem Cytochem 33:699-705

Boehringer Mannheim Biochemica (1992) Nonradioactive in situ hybridization. Application manual. Boehringer Mannheim Biochemica, Mannheim

Bondi A, Chieregatti G, Eusebi V, Fulcheri E, Bussolati G (1982) The use of $\beta$-galactosidase as a tracer in immunocytochemistry. Histochemistry 76:153-158

Brahic M, Haase AT, Cash E (1984) Simultaneous in situ detection of viral RNA and antigens. Proc Natl Acad Sci USA 81:5445-5448

Bridge JA, De Boer J, Travis J, Johansson SL, Elmberger G, Noel SM, Neff JR (1994) Simultaneous interphase cytogenetic analysis and fluorescence immunophenotyping of dedifferentiated chondrosarcoma. Am J Pathol 144:215-220

Brigati DJ, Myerson D, Leary JJ, Spalholz B, Travis SZ, Fong CKY, Hsiung GD, Ward DC (1983) Detection of viral genomes in cultured cells and paraffin-embeddled tissue sections using biotinlabeled hybridization probes. Virology 126:32-50

Bronstein I, Voyta JC, Edwards B (1989) A comparison of chemiluminescent and colorimetric substrates in a Hepatitus B virus DNA hybridization assay. Anal Biochem 180:95-98

Buckle VI, Kearney L (1993) Umtwirling dirvish. Nature Genet 5:4-5

Carothers AD (1994) Counting, measuring, and mapping in FISH-labelled cells: sample size considerations and implications for automation. Cytometry 16:298-304

Celeda D, Bettag U, Cremer C (1992) PCR amplification and simultaneous digoxigenin incorporation of long DNA probes for fluorescence in situ hybridization. Biotechniques 12:98 102

Caleda D, Aldinger K, Haar F-M, Hausmann M, Durm M, Ludwig H, Cremer C (1994) Rapid fluorescence in situ hybridization with repetitive DNA probes: quantification by digital image analysis. Cytometry 17:13-25

Chin-Yang L, Zeismer SC, Lazcano-Villareal O (1987) Use of azide and hydrogen peroxide as am inhibitor for endogenous peroxidase in immunoperoxidase method. J Histochem Cytochem $35: 1457$ 1460

Chin K-P, Cohen SH, Morris DW, Jordan GW (1992) Intracellular amplification of proviral DNA in tissue sections using the polymerase chain reaction. I Histochem Cytochem 40:333-341

Chaassen E, Boorsma DM, Kors N, Van Rooijen N (1986) Double-enzyme conjugates, producing an intermediate color "for simultaneous and direct detection of three different intracellular immunoglobulin determinants with only two enzymes. J Histochem Cytochem 34:423-428

Coggi G, Dell'Orto P, Viale G (1986) Avidin-biotin methods. In Polak JM, Van Noorden S (eds): Immunocytochemistry. Modern methods and applications. Bristol, Wright, pp 54-70 
Cornelese-ten Velde I, Prins FA (1990) New sensitive light microscopical detection of colloidal gold on ultrathin sections by reflection contrast microscopy. Combination of reflection contrast and electron microscopy in post-embedding immunogold histochemistry. Histochemistry 94:61-71

Cormelese-Ten Velde I, Bonnet I, Tanke HJ, Ploem IS (1988) Reflection contrast microscopy. Vistalization of (peroxidase-generated) diaminobenzidine polymer products and its underlying optical phenomena. Histochemistry $89: 1411-150$

Cunningham DA, Pattison IR, Craig RK (1988) Detection of parvovirus DNA in human serum using biotinylated RNA hybridization probes. I Virol Methods 19:279-288

Danscher G (1981) Localization of gold in biological tisswe. A photochemical method for light and electronmicroscopy. Histochemistry $71: 81-88$

Dawwerse JG, Wiegant J, Raap AK, Breuning MH, Van Ommen GJB (1992) Multiple colors by fluorescence in situ hybridization using ratio-labelled DNA probes create a molecular karyotype. Human Molecular Genetics 1:593-598

De Block M, Debrouwer D (1993) RNA-RNA in situ hybridization using digoxigenin-labeled probes: the use of high-molecular-weight polyvinyl alcohol in the alkaline phosphatase indoxyl-nitroblue tetrazolium reaction. Anal Biochem 215:86-89

Deitch JS, Smith KL, Swann JW, Turner JN (1990) Parameters affecting imaging of the horseradishperoxidase-diaminobenzidine reaction product in the confocal scanning laser microscope. I Microsc $160: 265-278$

Dhingra K, Sneige N, Pandita TK, Johnston DA, Lee JS, Emami K, Hortobagyi GN, Hittelman WN (1994) Quantitative analysis of chromosome in situ hybridization signal in paraffin-embedded tissue sections. Cytometry $16: 100-112$

Dirks RW, Van Gijlswijk RPM, Vooijs MA, Smit AB, Bogerd J, Van Minmen J, Raap AK, Van der Ploeg M (1991) 3'End fluorochromized and haptenized oligonucleotides as in situ hybridization. probes for multiple, simultaneous RNA detection. Exp Cell Res 194:310-315

Dirks RW, Van Dorp AGM, Van Minnen J, Fransen JAM, Van der Ploeg M, Raap AK (1992) Electron microscopic detection of RNA sequences by non-radioactive in situ hybridization in the mollusk Lymnaea stagnalis. J Histochem Cytochem 40:1647-1657

Dirks RW, Van de Rijke FM, Fujishita S, Van der Ploeg M, Raap AK (1993) Methodologies for specific intron and exon RNA localization in cultured cells by haptenized and fluorochromized probes. J Cell Sci 104:1187-1197

Dunn JJ, Studier FW (1983) Complete nucleotide sequence of bacteriopthage T7 DNA and the locations of $\mathrm{T} 7 \mathrm{genetic}$ elements. J Mol Biol 166:477-535

Egger D, Troxler $M_{*}$ Bienz $K$ (1994) Light and electron microscopic in situ hybridization: non radiozuctive labeling and detection, double hybridization, and combined hybridization. immunocytochemistry. I Histochem Cytochem 42:815-822

Emmerich P, Loos P, Jauch A, Hopman AHN, Wiegant J, Higgins MJ, White BN, Van der Ploeg $M$, Cremer $C$, Cremer $T$ (1989) Double in situ hybridization in combination with digital image analysis: a new approach to study interphase chromosome topography. Exp Cell Res 181:126-140

Engel A (1991) Biological applications of scanning probe microscopes. Amnu Rev Biophys Chem 20:79-108 
Ernst LA, Gupta RK, Mujumdar RB, Waggoner AS (1989) Cyanine dye Labeling reagents for sulfhydryl groups. Cytometry 10:3-10

Feinberg AP, Vogelstein B (1984) A technique for radiolabeling DNA restriction endonuclease fragments to high specific activity. Anal Biochem 137:266-267

Ffrench M, Morel F, Souchier C, Benchaib M, Catallo R, Bryon PA (1994) Choice of fixation and denaturation for the triple labelling of intra-cytoplasmatic antigen, bromodeoxyuridine and DNA. Application to bone marrow cells. Histochemistry 101:385-390

Filler TI, Rickert CH, Fassnacht UK, Pera F (1994) Reflection contrast microscopy within chromealum haematoxylin stained thick tissue-sections. Histochemistry 101:375-378

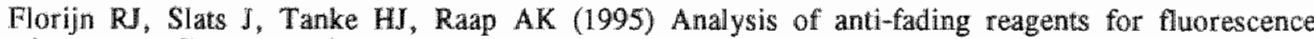
microscopy. Cytometry, in press

Gall JG, Pardue ML (1969) Formation and detection of RNA-DNA hybrid molecules in cytological preparations. Proc Natl Acad Sci USA 63:378-383

Garson JA, Van den Berghe IA, Kemshead IT (1987) Novel non-isotopic in situ hybridization technique detects small $(1 \mathrm{~kb})$ unique sequences in routinely $\mathrm{G}$-banded human chromosomes: fine mapping of $N$-myc and $\beta-N G F$ genes. Nucleic Acids Res 15:4761-4770

Gebeyehu G, Roa PY, Soo Chan P, Simms DA, KIevan L (1987) Novel biotinylated nucleotideanalogs for labelling and colorimetric detection of DNA. Nucleic Acids Res 15:4513-4534

Gendelman HE, Moench TR, Narayan O, Griffin DE, Clements JE (1985) A double labeling technique for performing immunocytochemistry and in situ hybridization in virus infected cell cultures and tissues. J Virol Methods 11:93-103

Gentilomi G, Musiani M, Zerbini M, Gibellini D, Gallinella G, Venturoli S (1992) Double in situ hybridization for detection of Herpes simplex virus and Cytomegalovirus DNA using non-radioactive probes. J Histochem Cytochem $40: 421-425$

Geoghegan WD, Scillian JI, Ackerman GA (1978) The detection of human B lymphocytes by both light and electron microscopy utilizing colloidal gold labeled anti-immunoglobulin. Immunol Commun $7: 1-12$

Gerhard DS, Kawasaki ES, Bancroft $\mathrm{FC}$, szabo $\mathrm{P}$ (1981) Localization of a unique gene by direct hybridization in situ. Proc Natl Acad Sci USA 78:3755-3759

Giloh H, Sedat JW (1982) Fluorescence microscopy: reduced photobleaching of rhodamine and fluorescein protein conjugates by n-propyl gallate. Science 217:1252 1255

Gosden J, Hanratty D (1991a) Comparison of sensitivity of three haptens in the prins (oligonucleotide primed in situ DNA synthesis) reaction. Technique 3:159-165

Gosden J, Hanratty D, Starling J, Fantes J, Mitchell A, Porteous D (1991b) Oligonucleotide-primed in situ DNA synthesis (PRINS): a method for chromosome mapping, banding, and investigation of sequence organization. Cytogenet Cell Genet 57:100-104

Gosdlen J, Hanratty D (1993) PCR in situ: a rapid alternative to in situ hybridization for mapping short, low copy number sequences without isotopes. Biotechniques 15:78-80

Gosden J, Lawson D (1994) Rapid chromosome identification by oligonucleotide-primed in situ DNA synthesis (PRINS). Human Molecular Genetics 3:931-936 
Gown AM (1988) Immunoglucose oxidase methods in immunohistochemistry. In Delellis RA (eds): Advances in immunohistochemistry. New York, Raven Press, pp $31-45$

Graham AK, Herrington CS, McGee JO'D (1991) Simultaneous in situ genotyping and phenotyping of human papillomavirus cervical lesions: comparative sensitivity and specificity. I Clin Pathol $44: 96-101$

Graham RC, Karnovsky MJ (1966) The early stages of absorption of injacted horseradisth peroxidase in the proximal tubules of mouse kidney: ultrastructural cytochemistry by a new technique. I Histochem Cytochem 14:291-302

Graham RC, Lundholm U, Karnovsky MJ (1965) Cytochemical demonstration of peroxidase activity with 3-amino-9methyl carbazole. J Histochem Cytochem 13:150-152

Green NM (1975) Avidin. In Anfinsen CB, Edsall JT, Richards FM (ods): Adwances in protein chemistry. New York, Academic Press, pp 85-133

Haaf $\mathrm{T}$, Ward DC (1994) High resolution ordering of YAC contigs using extended chromatin and chromosomes. Human Molecular Genetics 3:629-633

Haase AT, Retzel EF, Staskus KA (1990) Amplification and detection of lentiviral DNA inside cells. Proc Natl Acad Sci USA 87:4971-4975

Hacker GW, Zehbe I, Hauser-Kronberger C, Gu J, Graf A-H, Dietze O (1994) In situ detection of DNA and mRNA sequences by inmunogold-silver staining (IGSS). Cell Vision 1:30-37

Harper ME, Marselle LM, Gallo RC, Wong-Stahl F (1986) Detection of Iymphocytes expressing human T-dymphotrophic virus type TII in lymph nodes and peripheral blood from infected individuals by in situ hybridization. Proc Natl Acad Sci USA 83:772-776

Harper SJ, Pringle JH, Gillies A, Allen AC, Layward L, Feehally I, Lauder II (1992) Simultaneous in situ hybridization of native mRNA and immunoglobulin detection by conventional immunofluorescence in paraffin wax embedded sections. J Clin Pathol 45:114-119

Haugland RP (1994) Handbook of fluorescent probes and research chemicals. Molecular Probes, Eugene, OR, USA

Hawkins $E$, Cumming $\mathbb{R}$ (1990) Enhanced chemiluminescence for tissue antigen and cellular viral DNA detection. II Histochem Cytochem 38:415-419

Hayashi S, Gillam IC, Delaney AB, Tener GM (1978) Acetylation of chromosome squashes of Drosophila melanogaster decreases the background in autoradiographs from hybridisation with 125Ilabelled RNA. J Histochem Cytochem 26:677-679

Hayat MA (1993) Immunogold-silver staining overview. J Histotechnol 16:197-199

Heppelmann B, Señaris R, Emson PC (1994) Combination of alkaline phosphatase in situ hybridization with immunohistochemistry: colocallization of calretinin-mRNA with calbindin and tyrosine hydroxylase immunoreactivity in rat substantia nigra neurons. Brain Res 635:293-299

Herbergs J, De Bruïne AP, Marx PTJ, Vallinga MIJ, Stockbrügger RW, Ramatekers FCS, Arends JW, Hopman AHN (1994) Chromosome aberrations in adenomas of the colon. Proof of trisomy 7 in tumor cells by combined interphase cytogenetics and immunocytochemistry. Int I Cancer 57:781-785

Herrington CS, Burns J, Graham AK, Bhatt B, McGee JO'D (1989) Interphase cytogenetics using biotin and digoxygenin labelled probes II: simultaneous differential detection of human and papilloma virus nucleic acids in individual nuclei. J Clin Pathol 42:601-606 
Heyting $C$, Kroes W, Kriek $E_{5}$ Meyer I, Slater R (1985) Hybridization of N-acetoxy-N-acetyl-2aminofluorene-labelled RNA to Q-banded metaphase chromosomes. Acta Histochem 77:177-184

Hindkjaer J, Koch J, Terkelsen C, Brandt CA, Kolwra S, Bolund L (1994) Fast, sensitive multicolor detection of nucleic acids in situ by primed in situ labeling (PRINS). Cytogenet Cell Genet 66:152154

Hôtler H (1993) In situ polymerase chain reaction: toy or tool? Histochemistry 99:103-104

Hoefsmit ECM, Korn C, Blijleven N, Ploem JS (1986) Light microscopical detection of single 5 and $20 \mathrm{~nm}$ gold particles used for immunolabelling of plasma membrane antigens with silver enthancement and reflection contrast. J Microse 143:161-169

Hoeltke HJ, Kessler C (1990) Non-radioactive labeling of RNA transcripts in vitro with the hapten digoxigenin (DIG): hybridization and ELISA-based detection. Nucleic Acids Res 1 8:5843-5851

Hoeltke HJ, Ettl I, Finken M, West S, Kunz W (1992) Multiple nucleic acid labeling and rainbow detection. Anal Biochem 207:24-31

Hoh JH, Hansma PK (1992) Atomic force microscopy for high resolution imaging in cell biology. Trends Cell Biol 2:208-213

Holgate CS, Jackson P, Cowen PN, Bird CC (1983) Immunogold-silver staining: new method of immunostaining with enhanced sensitivity. J Histochem Cytochem $31: 938-944$

Hopman AHN, Wiegant J, Raap AK, Landegent JE, Van der Ploeg M, Van Duijn P (1986) Bi-color detection of two target DNAs by non-radioactive in situ hybridization. Histochemistry $85: 1-4$

Hopman AHN, Raap AK, Landegent JE, Wiegant J, Boerman RH, Van der Ploeg M (1988a) Nonradlioactive in situ hybridization. In Van Leeuwen FW, Bujjs RM, Pool CW, Pach O (eds): Molecular Neuroanatomy. Amsterdam, Elsevier Science Publishers BV, pp 43-68

Hopman AHN, Ramaekers FCS, Raap AK, Beck JLM, Devilee P, Van der Ploeg M, Vooijs GP (1988b) In situ hybridization as a tool to study numerical chromosome aberrations in solid bladder tumors. Histochemistry 89:307-316

Hopman AHN, Ramaekers FCS, Vooijs GP (1990) Interphase cytogenetics of solid tumours. In Polak JM, McGee JO'D (eds): In situ hybridization: principles and practice. Oxford, Oxford University Press, pp 165-186

Hopman AHN, Van Hooren E, Van de Kaa CA, Vooijs GP, Ramaekers FCS (1991) Detection of numerical chromosome aberrations using in situ hybridization in paraffin sections of routinely processed bladder cancers. Modern Pathol 4:503-513

Hopman AHN, Speel EJM, Voorter CEM, Ramaekers FCS (1995) Probe labelling methods. In Levy ER, Herrington CS (eds): Non-isotopic techniques in molecular biology: a practical approach. Oxford, IRL Press, Oxford University Press, in press

Houseal TW, Dackowski WR, Landes GM, Klinger KW (1994) High resolution mapping of overlapping cosmids by fluorescence in situ hybridization. Cytometry 15:193-198

Huang $Z$, Terpetschnig $E_{*}$ You $W$, Haugland RP (1992) 2-(2*-Phosphoryloxyphenyl)-4(3H)quinazolinone derivatives as fluorogenic precipitating substrates of phosphatases. Anal Biochem $207: 32-39$

Ikizyan $\mathbb{I A}$, Burde S, Leary JF (1994) Interactive 3-D image analysis and visualization techniques for FISH-labelled chromosomes in interphase nuclei. Bioimaging 2:41-56 
Jirikowsky GF, Ramalho-Ortigao JF, Lindl $T$, Seliger H (1989) Immunocytochemistry of 5-bromo$2^{2}$-deoxyuridine labelled oligonucleotide probes. Histochemistry 91:51-53

John HA, Birnstiel ML, Jones KW (1969) RNA-DNA hybrids at the cytological level. Nature $223.582-587$

Johnson CV, McNeil JA, Carter KC, Lawrence JB (1991) A simple, rapid technique for precise mapping of multiple sequences in two colors using a single optical filter set. Genet Anal Tech Appl $8: 75-76$

Johnson GD, Davidson RS, McNamee KC, Russell G, Goodwin D, Holborow EJ (1982) Fading of immunofluorescence during microscopy: a study of the phenomenon and its remedy. $\mathrm{J}$ Immunol Methods $55: 231-242$

Kagiyama N, Fujita $S$, Momiyama $M$, Saito $H$, Shirahama H, Hori SH (1992) A fluorescent detection method for DNA hybridization using 2-hydroxy-3-naphthoic acid-2'-phenylanilide phosphate as a substrate for alkaline phosphatase. Acta Histochem Cytochem 25:467-471

Kagiyama $N$, Yoshida $K$, Hamabata $T$, Juni $N$, Awasaki $T$, Fujita $S$, Momiyama M, Kondoh $Y$, Yoshida MC, Hori SH (1993) A novel fluorescent method for in situ hybridization. Acta Histochem Cytochem $26: 441-445$

Kassavetis GA, Butler ET, Roulland D, Chamberlin MJ (1982) Bacteriophage SP6-specific RNA polymerase. E. Mapping of SP6 DNA and selective in vitro transcription. J Biol Chem 257:57795788

Kerstens HMJ, Poddighe PJ, Hanselaar AGJM (1994) Double-target in situ hybridization in brightfield microscopy. J Histochem Cytochem 42:1071-1077

Kerstens HJM, Poddighe PJ, Hanselaar AGJM (1995) A novel in situ hybridization signal amplification method, based on the deposition of biotinylated tyramine. J Histochem Cytochem, in press

Khalfan H, Abuknesha R, Rand-Weaver M, Price RG, Robinson D (1986) Aminomethyl coumarin acetic acid: a new fluorescent labelling agent for proteins. Histochem J 18:497-499

Kibbelaar RE, Van Kamp H, Dreef EJ, De Groot-Swings G, Kluin-Nelemans JC, Beverstock GC, Fibbe WE, Kluin PM (1992) Combined immunophenotyping and DNA in situ hybridization to study lineage involvement in patients with myelodysplastic syndromes. Blood 79:1823-1828

Kibbelaar RE, Kok F, Dreef EJ, Kleiverda JK, Cornelisse CJ, Raap AK, Kluin PM (1993) Statisticall methods in interphase cytogenetics: an experimentall approach. Cytometry 14:716-724

Kiyama H, Emson PC (1991) An in situ hybridization histochemistry method for the use of alkaline phosphatase-labeled oligonucleotide probes in small intestine. J Histochem Cytochem 39:1377-1384

Koch J, Kolvraa S, Petersen KB, Gregersen N, Bolund L (1989) Oligonucleotide-priming methods for the chromosome-specific labelling of alpha satellite DNA in situ. Chromosoma 98:259-265

Koch J, Hindkjær J, Mogensen J, Kolwraa S, Bolund L (1991) An improved method for chromosome-specific labeling of $\alpha$ satellite DNA in situ by using denatured double-stranded DNA probes as primers in a primed in situ labeling (PRINS) procedure. Genet Anal Tech Appl 8:171-178

Komminoth P, Long AA (1993) In-situ polymerase chain reaction. An overview of methods, applications and limitations of a new molecular technique. Virchows Archiv B Cell Pathol 64:67-73 
Krenik KD, Kephart GM, Offord KP, Dunette SL, Gleich GJ (1989) Comparison of antifading agents used in immunofluorescence. J Immunol Methods 117:91-97

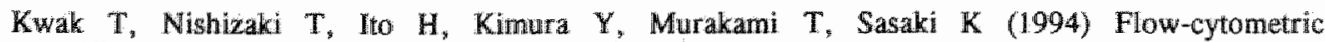
quantification in human gliomas of alpha satellite DNA sequences specific for chromosome 7 using fluorescence in situ hybridization. Cytometry $17: 26-32$

Landegent JE, Jansen in de Wal $N$, Van Ommen G-IB, Baas F, De Vijlder JJM, Van Duijn P, Van der Ploeg $M$ (1985) Chromosomal localization of a unique gene by non-autoradiographic in situ hybridization. Nature 317:175-177

Larsson L-I. (1988) Immunocytochemical detection systems. In Immunocytochemistry: theory and practice. Boca Raton, CRC Press, pp 77-145

Larsson LI, Hougaard DM. (1991) Combined non-radioactive detection of peptide hormones and their mRNA's in endocrine cells. Histochemistry 96:375-380

Lawrence JB, Singer RH (1985) Quantitative analysis of in situ hybridization methods for the detection of actin gene expression. Nucleic Acids Res 13:1777-1.799

Leger I, Robert-Nicoud M, Brugal G (1994) Combination of DNA in situ hybridization and immunocytochemical detection of nucleolar proteins: a contribution to the functional mapping of the human genome by fluorescence microscopy. J Histochem Cytochem 42:149-154

Leitch AR, Schwarzacher $T$, Jackson D, Leitch If (1994) In situ hybridization. Oxford, Bios Scientific Publishers

Lengauer C, Speicher MR, Popp S, Jauch A, Taniwaki M, Nagaraja R, Riethman HC, Donis-Keller $H$, D'Urso M, Schlessinger D, Cremer T (1993) Chromosomal bar codes produced by multicolor fluorescence in situ hybridization with multiple YAC clones and whole chromosome painting probes. Human Molecular Genetics 2:505-512

Lichter P, Chang Tang C-J, Call K, Hermanson G, Evans GA, Housman D, Ward DC (1990) Highresalution mapping of human chromosome 11 by in situ hybridization with cosmid clones. Science $247: 64-69$

Lichter P, Boyle AL, Cremer T, Ward DC (1991) Analysis of genes and chromosomes by nonisotopic in situ hybridization. Genet Anal Tech Appl 8:24-35

Linares-Cruz, G, Rigaut JP, Vassy J, De Oliveira TC, De Cremoux P, Olofsson B, Calvo F (1994) Reflectance in situ hybridization (RISH): detection, by confocal reflectance laser microscopy, of gold-labelled riboprobes in breast cancer cell lines and histological specimens. J Microsc 173:27-38

Lorimier P, Lamarcq L, Labat-Moleur F, Guillermet C, Bethier R, Stoebner P (1993) Enhanced chemilumimescence: a high-sensitivity detection system for in situ hybridization and immunohistochemistry. J Histochem Cytochem 41:1591-1597

Losada AP, Wessman M, Tiainen M, Hopman AHN, Willard HF, Sole F, Rosa Caballin M, Woessner $S$, Knutila $S(1991)$ Trisomy 12 in chronic lymphocytic leukemia: An interphase
cytogenetic study. Blood $78,775-779$

Malik NJ, Daymon ME (1982) Improved double immunoenzyme labelling using alkaline phosphatase and horseradish peroxidase. J Clin Pathol 35:1092-1094

Manuelidis L, Ward DC (1984) Chromosomal and nuclear distribution of the HindllI 1.9-kb human DNA repeat segment. Chromosoma $91: 28-38$ 
Martini E, Speel EJM, Geraedts JPM, Ramaekers FCS, Hopman AHN (1995) Application of different in situ hybridization detection methods for human sperm analysis. Hum Reprod, in press

Matthews JA, Kricka LJ (1988) Analytical strategies for the use of DNA probas. Anal Biochem 169:1-25

McFadden $G$, Bönig $I$, Clarke A (1990) Double label in situ hybridization for electron microscopy. Trans Roy Microscop Soc 1:683-688

McGadey J (1970) A tetrazolium method for non-specific alkaline phosphatase. Histochemistry $23: 180-184$

Mogensen J, Kolwraa S, Hindkjær J, Petersen S, Koch J, Nygäd M, Jensen T, Gregersen N, Junker $S$, Bolund $L$ (1991) Nonradioactive, sequence-specific detection of RNA in situ by primed in situ labeling (PRINS). Exp Cell Res 196:92-98

Mujumdar RB, Ernst LA, Mujumdar SR, Waggoner AS (1989) Cyanine dye labeling reagents containing isothiocyanate groups. Cytometry 10:11-19

Mullink H, Walboomers JMM, Raap AK, Meyer CJLM (1989a) Two colour DNA in situ hybridization for the detection of two wiral genomes using non-radioactive probes. Histochemistry 91:195-198

Mullink H, Walboomers JMM, Tadema TM, Jansen DJ, Meijer CJLM (1989b) Combined immunoand non-radioactiwe hybridocytochemistry on cells and tissue sections: influence of fixation, enzyme pre-treatment, and choice of chromogen on detection of antigen and DNA sequences. J Histochem Cytochem 37:603-609

Mullink H, Vos W, Jiwa M, Horstman A, Van der Valk P, Walboomers JMM, Meijer CJLM (1992) Application and comparison of silver intensification methods for the diaminobenzidine and diaminobenzidine-nickel endproduct of the peroxidation reaction in immunohistochemistry and in situ hybridization. J Histochem Cytochem 40:495-504

Multhaupt $H_{\text {, Gross }} G$, Fritz $P_{\text {, }}$ Köhler $K$ (1989) Cellular localization of induced human interferon- $\beta$ mRNA by non-radioactive in situ hybridization. Histochemistry 91:315-319

Murray GI, Ewen SWB (1992) A new fluorescence method for alkaline phosphatase histochemistry. I Histochem Cytochem 40:1971-1974.

Nakane PK (1968) Simultaneous localization of multiple tissue antigens using the peroxidase-labeled antibodly method: A study on pituitary glands of the rat. J Histochem Cytochern 16:557-560

Naoumov NV, Alexander GJM, Eddleston ALWF, Williams R (1988) In situ hybridisation in formalin fixed, paraffin wax embedded liver specimens: method for detecting human and viral DNA using biotinylated probes. I Clin Pathol 41:793-798

Narayanswami S, Hamkalo BA (1991) DNA sequence mapping using electron microscopy. Genet Anal Tech Appl 8:14-23

Nederlof PM, Robinson D, Abuknesha R, Wiegant J, Hopman AHN, Tanke HJ, Raap AK (1989) Three-color fluorescence in situ hybridization for the simultaneous detection of multiple nucleic acid sequences. Cytometry 10:20-27

Nederlof PM, Van der Flier S, Verwoerd NP, Vrolijk J, Raap AK, Tanke HJ (1992) Quantification of fluorescence in situ hybridization signals by image cytometry. Cytometry 13:846-852 
Nibbering PH, Marijnen JGJ, Raap AK, Leijh PCJ, Van Furth R (1986) Quantitative study of enzyme immunocytochemical teactions performed with enzyme conjugates immobilized on nitrocellulose. Histochemistry $84: 538-543$

Nuovo GI (1992) PCR in sitn hybridization. Protocols and applications. New York, Raven Press

Parra I, Windle B (1993) High resolution visual mapping of stretched DNA by fluorescent hybridization. Nature Genet 5:17-21

Pinkel D, Straume T, Gray JW (1986) Cytogenetic analysis using quantitative, high-sensitivity, fluorescence hybridization. Proc Nat Acad Sci USA 83:2934-2938

Ploem JS (1975) Reflection contrast microscopy as a tool for investigation of the attachment of living cells to a glass surface. In Van Furth $R$ (eds): Mononuclear phagocytes in immunity, infection and pathology. Oxford, Blackwell, pp 405-421

Pollard-Knight D (1990) Current methods in nonradioactive nucleic acid llabeling and detection. Technique 2:113-132

Ponder BA, Wilkinson MM (1981) Inhibition of endogenous tissue alkaline phosphatase with the use of alkaline phosphatase conjugates in immunohistochemistry. J Histochem Cytochem 29:981-984

Porter HJ, Heryet A, Quantrill AM, Fleming KA (1990) Combined non-isotopic in situ hybridization and immunohistochemistry on routine paraffin wax embedded tissue: Identification of cell type infected by human parvovirus and demonstration of cytomegalovirus DNA and antigen in renal infection. J Clin Pathol 43:129-132

Putman CAJ, De Grooth BG, Wiegant $J$, Raap AK, Van der Werf KO, Van Hulst NF, Greve J (1993) Detection of in situ hybridization to human chromosomes with the atonic force microscope. Cytometry 14:356-361

Raap AK (1986) Localization properties of fluorescence cytochemical enzyme procedures. Histochemistry $84: 317-321$

Raap AK, Marijnen JGJ, Van der Ploeg M (1984) Anti-DNA.RNA sera. Specificity tests and application in quantitative in situ hybridization. Histochemistry $81: 517-520$

Raap AK, Hopman AHN, Van der Ploeg M (1989) Hapten labeling of nucleic acid probes for DNA in situ hybridization. In Bullock GR, Petrusz $P$ (eds): Techniques in Immunocytochemistry. Cambridge, Cambridge University Press, pp 167-197

Raap AK, Van de Corput MPC, Vervenne RAW, Van Gijlswijk RPM, Tanke HJ, Wiegant J (1995) Iltra-sensitive FISH using peroxidase-mediated deposition of biotin. or fluorochrome tyramide. Hum Molec Genet 4 , in press

Rawlins DJ, Shaw PJ (1990) In situ hybridization with digoxygenin-labelled probes and 1 nm gold conjugated antibodies with confocal optical sectioning and image reconstruction to describe the 3-D arrangement of rDNA in intact plant tissue. Trans Roy Microscop Soc 1:675-678

Ried $T_{*}$ Baldini $A$, Rand $T C_{w}$ Ward DC (1992) Simultaneous visualization of seven different DNA probes by in situ hybridization using combinatorial fluorescence and digital imaging microscopy. Proc Natl Acad Sci USA 89:1388-1392

Rigby PWJ, Dieckmann M, Rhodes C, Berg P (1977) Labeling deoxyribonucleic acid to high specific activity in vitro by nick translation with DNA polymerase I. J Mol Biol 113:237-251 
Riley LK, Marshall ME, Coleman MS (1986) A method for biotinylating oligonucleotide probes for use in molecular hybridizations. DNA 5:333-337

Robben H, Van Dekken H, Poddighe PJ, Vooijs GP (1994) Identification of aberrant cells in cytological specimens by combined in situ hybridization and immunocytochemistity. Cytopathology $5: 384-391$

Robinson JM, Batten BE (1989) Detection of diaminobenzidine reactions using scanning laser confocal reflectance microscopy. Histochem Cytochem 37:1761-1765

Robinson JM, Batten BE (1990) Localization of cerium-based reaction products by scanning laser reflectance confocal microscopy. J Histochem Cytochem 38:315-318

Rudkin GT, Stollar BD (1977) High resolution detection of DNA-RNA hybrids in situ by indirect immunofluorescence. Nature 265:472-473

Saiki RK, Scharf S, Faloona F, Mullis KB, Horn GT, Erlich HA, Arnheim N (1985) Enzymatic amplification of $\beta$-globin genomic sequences and restriction site analysis for diagnosis of sickle call anemia. Science $230: 1350-1354$

Santisteban M-S, Montmasson M-P, Giroud F, Ronot X, Brugal G (1992) Fluorescence image cytometry of nuclear DNA content versus chromatin pattern: a comparative study of tern fluorochromes. J Histochem Cytochem 40:1789-1797

Schmitz GG, Walter T, Seibl R, Kessler C (1991) Nonradioactive labeling of oligonucleotides in vitro with the hapten digoxigenin by tailing with terminal transferase. Anal Biochem 192:222-231

Schutte B, Reynders MMJ, Bosman FT, Blijham GH (1987) Studies with anti-bromodeoxyuridine antibodies: II. Simultaneous immunocytochemical detection of antigen expression and DNA synthesis by in vivo labeling of mouse intestinal mucosa. J Histochem Cytochem 35:371-374

Scopsi L, Larsson L-I (1986) Increased sensitivity in peroxidase immunocytochemistry. A comparative study of a number of peroxidase visualization methods employing a model system. Histochemistry 84:221-230

Seveus L, Väisälä M, Syrjänen S, Sandberg M, Kuusisto A, Harju R, Salo J, Hemmilä $\mathbb{I}$, Kojola H, Soini $E$ (1992) Time-resolved fluorescence imaging of europium chelate label in immunohistochemistry and in situ hybridization. Cytometry 13:329-338

Shivers BD, Harlan RE, Pfaff DW, Schachter BS (1986) Combination of immunocytochemistry and in situ hybridization in the same tissue section of rat pituitary. J Histochem Cytochem 34:39-43

Sibon OCM, Humbel BM, De Graaf A, Verkleil AJ, Cremers FFM (1994) Ultrastrucural localization of epidermal growth factor (EGF)-receptor transcripts in the cell nuclleus using preembedding in situ hybridization in combination with ultra-small gold probes and silver enhancement. Histochemistry $101: 223-232$

Singer RH, Langevin GL, Lawrence JB (1989) Ultrastructural visualization of cytoskeletal mRNAs and their associated proteins using double-label in situ hybridization. J Cell Biol 108:2343-2353

Soini EJ, Pelliniemi LJ, Hemmilä IA, Mukkala V-M, Kankare JJ, Frdjdman K (1988) Lanthanidle chelates as new fluorochrome labels for cytochemistry. J Histochem Cytochem 36:1449-1451

Speel EJM, Schutte B, Ramaekers FCS, Hopman AHN (1992a) The effect of awidin-biotin interactions in detection systems for in situ hybridization. J Histochem Cytochem 40:135-141 (Chapter 2) 
Speel EM, Schutte B, Wiegant J, Ramaekers FCS, Hopman AHN (1992b) A novel tuorescence detection method for in situ hybridization, based on the alkaline phosphatase-fast red reaction. I Histochem Cytochem 40:1299-1308 (Chapter 3)

Speel EJM, Kamps M, Bonnet J, Ramaekers FCS, Hopman AHN (1993) Multicolour preparations for in situ hybridization using precipitating enzyme cytochemistry in combination with reflection contrast microscopy. Histochemistry 100:357-366 (Chapter 4)

Speel EXM, Herbergs J, Ramaekers FCS, Hopman AHN (1994a) Combined immunocytochemistry and fluorescence in situ hybridization for simultaneous tricolor detection of cell cycle, genomic, and phenotypic parameters of tumor cells. I Histochem Cytochem 42:961-966 (Chapter 6)

Speel EIM, Jansen MPHM, Ramaekers FCS, Hopman AHN (1994b) A nowel triple-color detection procedure for brightfield microscopy, combining in situ hybridization with immunocytochemistry. I Histochem Cytochem 42:1299-1307 (Chapter 5)

Speel EJM, Schutte B, Ramaekers FCS, Hopman AHN (1994c) Non-fading high sensitivity confocal fluorescence imaging for in situ hybridization and immunocytochemistry. Biorad Application Note 14

Speel EJM, Lawson D, Hopman AHN, Gosden J (1995) Multi-PRINS: multiple sequential oligonucleotide primed in situ DNA synthesis reactions label specific chromosomes and produce bands. Hum Genet 95:29-33 (Chapter 7)

Straus W (1971) Inhibition of peroxidase by methanol and by methanol-nitroferricyanide for use in immunoperoxidase procedures. J Histochem Cytochem 19:682-688

Straus W (1972) Phenylhydrazine as inhibitor of horseradish peroxidase for use in immunoperoxidase procedures. J Histochern Cytochem 20:949-951

Strehl S, Ambros PF (1993) Fluorescence in situ hybridization combined with immunohistochemistry for highly sensitive detection of chromosome $\mathbb{1}$ aberrations in neuroblastoma. Cytogenet Cell Genet $63: 24-28$

Stuart WD, Bishop JG, Carson HL, Frank MB (1981) Location of the 18/28s ribosomal RNA genes in two Hawaiian Drosophila species by monocional immunological identification of RNA.DNA hybrids in situ. Proc Natl Acad Sci USA 78:3751-3754

Szarowski DH, Smith KL, Herchenroder A, Matuszek G, Swann JW, Turner JN (1992) Optimized reflection imaging in $l$ aser confocal microscopy and its application to neurobiology: modifications to the Biorad MRC-500. Scanning 14:104-111

Tanke HII (1989) Does light microscopy have a future? I Microsc 155:405-418

Terenghi G, Fallon RA (1990) Techniques and applications of in situ hybridization. In Underwood JCE (eds); Current topics in pathology. Berlin, Springer-Verlag, pp 289-337

Terkelsen C, Koch J, Kalvraa S, Hindkjaer J, Pedersen S, Bolund L (1993) Repeated primed in situ labeling: formation and labeling of specific DNA sequences in chromosomes and nuclei. Cytogenet Cell Genet 63:235-237

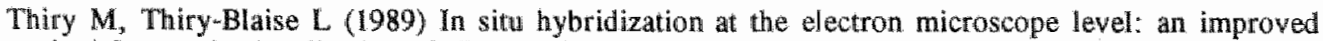
method for precise localization of ribosomal DNA and RNA. Eur J Cell Biol 50:235-243

Thiry M (1992) Highly sensitive immunodetection of DNA on sections with exogenous terminal deoxynucleotidyl transferase and non-isotopic nucleotide analogues. J Histochem Cytochem 40.411 419 
Thompson CT, LeBoit PE, Nederlof PM, Gray JW (1994) Thick-section fluorescence in situ thybridization on formalin-fixed, paraffin-embedded archival tissue provides a histogenetic profile. Am J Pathol 144:237-243

Thorpe GHG, Kricka $\mathbb{L J}$ (1986) Enhanced chemiluminescent reactions catalyzed by horseradish peroxidase. Meth Enzymol 133:331-353

Tocharoentanaphol $C$, Cremer $M_{3}$ Schröck $E$, Blonden $L$, Kilian $K$, Cremer $T$, Ried $T$ (1994) Multicolor fluorescence in situ hybridization on metaphase chromosomes and interphase Halopreparations using cosmid and YAC clones for the simultaneous high resolution mapping of deletions in the dystrophin gene. Hum Genet 93:229-235

Trainor GL, Jensen MA (1988) A procedure for the preparation of fluorescence-labeled DNA with terminal deoxynucleotidyl transferase. Nucleic Acids Res 16:11846

Trask B, Van den Engh $\mathbf{G}$, Landegent $J$, Jansen in de Wal $N$, Van der Ploeg $M$ (1985) Detection of DNA sequences in nuclei in suspension by in situ bybridization and dual beam flow cytometry. Science 230:1401-1403

Trask B, Pinkel D, Van den Engh G (1989) The proximity of DNA sequences in interphase cell muclei is correlated to genomic distance and permits ordering of cosmids spanning 250 kilobase pairs. Genomics 5:710-717

Trembleau A, Roche D, Calas A (1993) Combination of non-radioactive and radioactive in situ hybridization with immunohistochemistry: A new method allowing the simultaneous detection of two mRNAs and one antigen in the same brain tissue section. J Histochem Cytochem 41:489-498

Troyer DL, Goad DW, Xie H, Rohrer GA, Alexander LJ, Beattle CW (1994) Use of direct in situ singlewcopy (DISC) PCR to physically map five porcine microsatellites. Cytogenet Call Genet 67:199-204

Van Dekken H, Arkesteijn GJA, Visser JWM, Bauman JGJ (1990a) Flow cytometric quantification of human chromosome specific repetitive DNA sequences by single and bicolor fluorescent in situ hybridization to lymphocyte interphase nuclei. Cytometry 11:153-164

Van Dekken H, Van Rotterdam A, Jonker R, Van der Voort HTM, Brakenhoff GJ, Bauman JGJ (1990b) Confocal microscopy as a tool for the study of the intranuclear topography of chromosomes. J Microse 158:207-214

Van Dekken H, Schervish EW, Pizzolo JG, Fair WR, Molamed MR (1991) Simultaneous detection of fluorescent in situ hybridization and in vivo incorporated BrdU in a human bladder tumour. I Pathol 164:17-22

Van den Berg $H_{s}$ Vossen $M_{\text {, }}$ Van den Bergh $\mathbf{R L}$, Bayer $J$, Van Tol MJD (1991) Detection of $Y$ chromosome by in situ hybridization in combination with membrane antigens by wo-color immunoffuorescence, Lab Invest 64:623-628

Van den Brink W, Van der Loos $\mathrm{C}$, Volkers $\mathrm{H}$, Lauwen $\mathrm{R}$, Van den Berg $\mathrm{F}$, Houthoff $H$, Das PK. (1990) Combined $\beta$-Galactosidase and immunogold/silver staining for immunohistochemistry and DNA in situ hybridization. J Histochem Cytochem 38:325-329

Van den Brule AJC, Cromme FV, Snijders PJF, Smit L, Oudejans CBM, Baak JPA, Meijer CJLM, Walboomers JMM (1991) Nonradioactive RNA in situ hybridization detection of human papillomavirus 16-E7 transcripts in squamous cell carcinomas of the uterine cervix using confocal laser scan microscopy. Am J Pathol 139:1037-1045 
Van der Loos CM, Vokkers HH, Rook R, Van den Berg FM, Houthoff H-J (1989) Simultaneous application of in situ DNA bybridization and immunohistochemistry on one tissue section. Histochem J21:279-284

Van der Loos CM, Becker AE, Van den Oord JI (1993) Practical suggestions for successful immunoenzyme double-staining experiments. Histochem J 25:1-13

Van Noorden CJF, Vogels IMC (1989) Polyvinyl alcohol and other tissue protectants in enzyme histochemstry: a consumer's guide. Histochem J 21:373-379

Van Prooijen-Knegt $\mathrm{AC}_{3}$ Van Hoek JFM, Bauman JGJ, Van Duijn $\mathrm{P}$, Wool IG, Van der Ploeg $M$ (1982) In situ hybridization of DNA sequences in human mataphase chromosomes visualized by an indirect fluorescent immunocytochemical procedure. Exp Cell Res 141:397-407

Van Roy N, Mangelschots $K$, Speleman F (1993) Improved immunocytochemical detection of biotinylated probes with neutralite avidin. Trends Genet $9: 71-72$

Weber-Matthiesen K, Deerberg J, Müller-Hermelink A, Schlegelberger B, Grote W (1993a) Rapid immunophenotypic characterization of chromosomally aberrant cells by the new fiction method. Cytogenet Cell Genet 63:123-125

Weber-Mathiesen $K_{*}$ Muller-Hermelink A, Deerberg J, Scherthan $H$, Schlegelberger $B$, Grote W (1.993b) Discrimination of distinct subpopulations within a tumor with combined double immunophenotyping and interphase cytogenetics. J Histochem Cytochen $41: 1641-1644$

Weber-Matthiesen K, Pressl S, Schlegelberger B, Grote W (1993c) Combined immunophenotyping and interphase cytogenetics on cryostat sections by the new fiction method. Leukemia 7:646-649

Weier H-U, Segraves R, Pinkel D, Gray JW (1990) Synthesis of Y chromosome-specific labeled DNA probes by in vitro DNA amplification. J Histochem Cytochem $38: 421-426$

Wiegant $\mathrm{J}$, Reid $T$, Nederlof PM, Van der Ploeg M, Tanke HJ, Raap AK (1991) In situ hybridization with fluoresceinated DNA. Nucleic Acids Res 19:3237-3241

Wiegant I, Kalle W, Mullenders L, Brookes S, Hoovers JMN, Dauwerse JG, Van Ommen GJB, Raap AK (1992) High-resolution in situ hybridization using DNA halo preparations. Human Molecular Genetics 1:587-591

Wiegant $₫$, Wiesmeijer CC, Hoovers JMN, Schuuring $\mathbb{E}$, D Azzo A, Vrolijk J, Tanke HJ, Raap AK (1993) Multiple and sensitive fluorescence in situ hybridization with rhodamine-, fluorescein-", and coumarin-liabeled DNAs. Cytogenet Cell Genet 63:73-76

Woltson B, Manning RW, Davis LG, Arentzen R, Baldino fr F (1985) Co-localization of corticotropin releasing factor and vasopressin $\mathrm{mRNA}$ in neurones after adrenalectomy. Nature $315: 59-6 \|$

Zheng Y-1, Carter NP, Price CM, Colman SM, Milton PJ, Hackett GA, Greaves MF, FergusonSmith MA (1993) Prenatal diagnosis from maternal blood: simultaneous immunophenotyping and FISH of fetal nucleated erythrocytes isolated by negative magnetic cell sorting. $J$ Med Genet 30:1051-1056

Ziomek CA, Lepire ML, Torres I (1990) A highly fuorescent simultaneous azo dye technique for demonstration of nonspecific alkaline phosphatase activity. J Histochem Cytochem 38:437-442

Zirbel RM, Mathieu UR, Kurz A, Cremer T, Lichter P (1993) Evidence for a nuclear compartment of transcription and splicing located at chromosome domain boundaries. Chrom Res 1:93-106 


\section{CHAPTER 2}

\section{THE EFFECT OF AVIDIN-BIOTIN INTERACTIONS IN DETECTION SYSTEMS FOR IN SITU HYBRIDIZATION}

Ernst JM Speel, Bert Schutte, Frans CS Ramaekers, Anton HN Hopman

I Histochem Cytochem 40,135-141, 1992

\section{ABSTRRACT}

The effect of avidin-biotin interactions in several detection systems for the nonradioactive in situ hybridization (ISH) technique was studied in a model system using a transitional cell carcinoma line and a biotinylated DNA probe. We performed fluorescence ISH to unravel the individual steps in a sensitive and frequently used amplification method, which makes use of the alternating cytochemical detection layers of fluorescein isothiocyanate-conjugated avidin and biotinylated goat anti-avidin (BioGAA) antibodies to detect the hybridized and biotinylated probe. Our experiments revealed, that BioGAA antibodies bind with their antigen binding sites and not with their biotin moieties to avidin molecules that have already interacted with the DNA probe. The probable working mechanism of this amplification method is presented in a model. Furthermore, we used a peroxidase (PO) staining technique to compare with each other the sensitivity of several other detection systems in which avidin-biotin interactions play an important role, e.g., the avidin biotinylated PO complex (ABC) system. The experiments show, that avidin molecules can not be efficiently used to interconnect two biotinylated molecular layers, since their introduction leads to firmly closed cytochemical networks. Such a closed network is already formed between the hybridized and biotinylated DNA probe and a first detection layer of avidin molecules, as appears from the finding, that biotinylated molecules could hardly be coupled to these avidin molecules in a following detection layer. Therefore, the results presented here provide us with new insight into the molecular basis of cytochemical network formation. This will enable us to choose the proper procedures for increasing the sensitivity of ISH detection systems. 


\section{INTRODUCTION}

In situ hybridization (ISH) with non-radioactively labeled DNA probes is a sensitive method to detect target DNA sequences up to the level of single-copy genes of $1-6 \mathrm{~kb}$ (Garson et al., 1987; Albertson et al., 1988; Lawrence et al., 1988; Lichter et al., 1988; Viegas-Pequignot et al., 1989). To obtain this high detection sensitivity, a cytochemical amplification method (fluorescein isothiocyanate-conjugated avidin (AvFITC)/biotinylated goat anti-avidin (BioGAA) amplification method), as first described by Pinkel et al. (1986), is frequently used for fluorescence ISH studies (Cherif et al., 1990; Fan et al., 1990; Lichter et al., 1990; Tkachuk et al., 1990). The method includes the detection of biotinylated DNA with successive cytochemical layers of AvFITC and BioGAA antibodies, as illustrated in Figure 1.

Recently, several laboratories have made efforts to enhance the ISH detection sensitivity by using DNA molecules for signal amplification (Bresser and EvingerHodges, 1987; Landegent, 1987; Haase et al., 1990). In a radioactive approach, Haase and co-workers (1990) combined the polymerase chain reaction with ISH for the detection of lentiviral DNA inside cells. Despite a high detection sensitivity, only discrimination between virus-containing and virus-negative cells was possible, while information on the exact site of virus integration could not be obtained. This is due to diffusion of the newly synthesized DNA strands away from the site of their primary synthesis, and thus away from the target to be detected.

In another approach Landegent (1987) tried to anchor single-stranded DNA molecules ("catenation clones") via hybridization to a primary hybridized probe, to enhance specific ISH signals. These efforts were unsuccessful, probably because of penetration problems of the DNA molecules used and limitations in the stability of the hybrids in such networks.

Still another procedure to enhance the ISH detection sensitivity was described by Bresser and Evinger-Hodges (1987), who claimed a detection sensitivity of one to ten mRNA molecules per cell. These authors have used AvFITC/StrAvFITC (FITCconjugated streptavidin) mixtures, which were added to the slides after hybridization but before the washing steps, to allow the formation of a complex of AvFITC/StrAvFITC with the intracellularly bound biotinylated probe as well as with the unbound probe. However, this procedure appeared not to be reproducible as stated by Bakkus et al. (1989). We were atso unsuccessful in increasing the ISH detection sensitivity with this method (unpublished results). Therefore, as an alternative approach we chose to form cytochemical networks consisting of alternating layers of AvFITC and biotinylated DNA molecules (50-500 bases) on a primary hybridized and biotinylated DNA probe. Since also with this procedure no enhancement of specific ISH signals could be achieved (unpublished results), we studied the factors involved in the formation of cytochemical networks used in such procedures. Special attention was given to the role of avidin-biotin interactions, which form an essential part of the AvFITC/BioGAA amplification method and of the avidin biotinylated horseradish peroxidase ( $\mathrm{PO}$ ) method ( $\mathrm{ABC}$ method). 


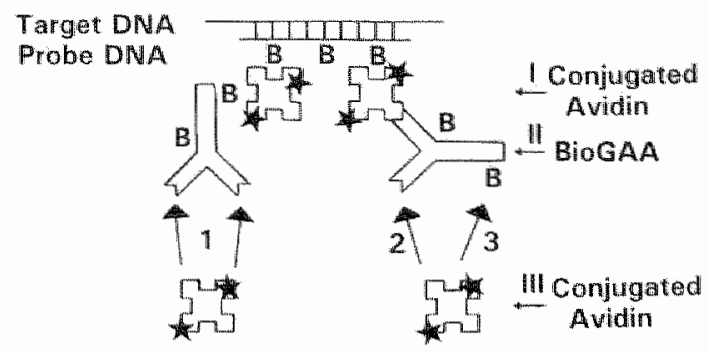

Figure 1. Diagram illustrating the mechanism of the amplification method as described by Pinkel et al. (1986). The three possibilities for binding of conjugated avidin to the bi-reactive BioGAA molecule in the third incubation step (III) are indicated by arrows 1-3. B, biotin; * , fluorochrome or enzyme (conjugated to avidin); BioGAA, biotinylated goat anti-avidin.

\section{MATERIALS AND METHODS}

\section{Tumor cell processing}

In all experiments, the human transitional cell carcinoma line T24 was used [DNA index 1.6; trisomic for the centromere of chromosome 1; (Bubenik et al., 1973)]. Cells were trypsinized, harvested, fixed in $70 \%$ ethanol $\left(-20^{\circ} \mathrm{C}\right)$, and stored at $-30^{\circ} \mathrm{C}$ as described by Hopman et al. (1988). Of the cell suspension obtained in this way, 5 $\mu \mathrm{l}\left(3 \times 10^{6} \mathrm{cells} / \mathrm{ml}\right)$ were dropped on poly-L-lysine-coated slides. The slides were airdried and heated for $1 \mathrm{hr}$ at $80^{\circ} \mathrm{C}$ on a heating plate. Pepsin from porcine stomach mucosa (2500-3500 U/mg protein; Sigma, St Louis, MO, USA) was applied at a concentration of $100 \mu \mathrm{g} / \mathrm{ml}$ in $0.01 \mathrm{M} \mathrm{HCl}$ for $20 \mathrm{~min}$ at $37^{\circ} \mathrm{C}$. After five washes in demineralized water (Milli Q) and five subsequent washes in phosphate-buffered

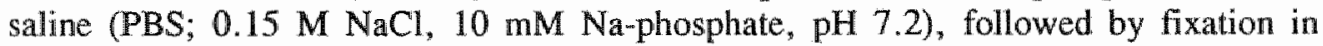
$1 \%$ paraformaldehyde in PBS for 20 min at $4^{\circ} \mathrm{C}$, five washes in PBS and five washes in Milli $Q$, the slides were equilibrated in $60 \%$ formamide, $2 \times S S C ~(0.3 \mathrm{M} \mathrm{NaCl}$ and $30 \mathrm{mM}$ Na-citrate), pH 5.0, containing $0.05 \%$ Tween 20 (Merck, Darmstadi, Germany) for $5 \mathrm{~min}$ at room temperature (RT) and washed in $2 \times S S C$, pH 7.0 , for 5 min at $R T$.

\section{DNA probes and labeling}

In all experiments we used a DNA probe for chromosome 1 (pUC 1.77) as described by Cooke and Hindley (1979), which recognizes andem repeat of $1.77 \mathrm{~kb}$ in the (peri)centromeric region (1q12). Biotinylation of this probe was performed using biotin-11-dUTP (Enzo Diagnostics, New York, NY, USA) in a nick translation reaction as described by Brigati et al. (1983).

\section{In situ hybridization}

The DNA probe was hybridized under high stringency conditions to its target DNA in pre-treated T24 cells in $60 \%$ formamide, $2 \times S S C, \mathrm{pH} 5.0,2 \mathrm{ng} / \mu 1$ herring sperm 
DNA as carrier DNA and $2 \mathrm{ng} / \mu \mathrm{l}$ yeast tRNA as carrier RNA, at a probe concentration of $40 \mathrm{pg} / \mu \mathrm{l}$ hybridization mixture. Of the hybridization mixture, $10 \mu \mathrm{l}$ were added to the slides and covered with a coverslip $(20 \times 20 \mathrm{~mm})$. Denaturation was performed at $70^{\circ} \mathrm{C}$ on a heating plate for $3 \mathrm{~min}$. Hybridization was performed overnight at $37^{\circ} \mathrm{C}$. Post-hybridization washes were done twice in $60 \%$ formamide, $2 \times S S C$, pH 5.0 , containing $0.05 \%$ Tween 20 for 10 min at $42^{\circ} \mathrm{C}$, twice in $2 \times S S C$, $\mathrm{pH} 7.0$, for $10 \mathrm{~min}$ at $42^{\circ} \mathrm{C}$, and once in $4 \times \mathrm{SSC}, \mathrm{pH} 7.0$, containing $0.05 \%$ Tween 20 (Buffer A) for 5 min at RT.

\section{Cytochemical detection}

To reduce background staining, the slides were pre-incubated with $4 \mathrm{xSSC}, \mathrm{pH} 7.0$, containing $5 \%$ non-fat dry milk for 10 min at RT, followed by dipping in Buffer A. Detection of the biotinylated DNA probe hybridized to its target on chromosome 1 was performed using different, subsequent incubation steps as shown in Tables 1-3 (see 'Results'). The following cytochemical reagents and conjugates were used:

1. The $A B C$ system was used according to the manufacturer"s instructions ( $A B C$ elite kit; Vector, Brunschwig Chemie, Amsterdam, The Netherlands).

2. Avidin, biotinylated $P O$ ( $B i o P O$ ) (both from the $A B C$ elite kit), and biotinylated goat anti-rabbit IgG (BioGAR) were diluted 1:50 (all from Vector).

3. AvFITC, tetramethylrhodamin isothiocyanate (TRITC)-conjugated avidin (AvTRITC), BioGAA, and biotinylated horse anti-mouse IgG (BioHAM, from the $A B C$ elite kit) were diluted 1:100 (all from Vector).

4. Biotin was used at a concentration of $32 \mu \mathrm{g} / \mathrm{ml}$ Buffer A (from Boehringer, Mannheim, Germany).

5. PO-conjugated swine anti-rabbit IgG (SWARPO) was diluted 1:40 (Dakopatts, Glostrup, Denmark).

6. PO-conjugated avidin (AvPO) was diluted 1:80 (Dakopatts).

7. Mouse anti-biotin (MABio), FITC-conjugated rabbit anti-mouse IgG (RAMFITC), and PO-conjugated rabbit anti-mouse IgG (RAMPO) were diluted 1:100 (all from Dakopatts).

AvFITC and AvTRITC were diluted in Buffer A, AvPO and BioPO were diluted in PBS containing $0.05 \%$ Tween 20 (Buffer B), and all the antibodies were diluted in Buffer $\mathrm{B}$ containing $2 \%$ normal rabbit serum. Each incubation step of $30 \mathrm{~min}$ at $37^{\circ} \mathrm{C}$ was followed by washing the slides twice for $5 \mathrm{~min}$ at RT in Buffer A or Buffer B (depending on the dilution buffer).

For the fluorescence approach, the slides were dehydrated and mounted in PBS/glycerol (1:9 v/v), containing 2.3\% 1,4-di-azobicyclo-(2,2,2,)-octane (DABCO) (Sigma) (Böck et al., 1985) and $0.5 \mu \mathrm{g} / \mathrm{ml} \mathrm{4}, 6$-diamino-2-phenyl indole (DAPI) (Sigma). Microphotographs were taken with a Leitz Diallux 20 EB microscope, equipped with appropriate filters for FITC, TRITC, and DAPI fluorescence using a Kodak Tmax 400 ASA black-and-white film (TMY 135-36). Exposure times were approximately $15 \mathrm{sec}$ for FITC, and TRITC fluorescence, and $1 \mathrm{sec}$ for DAPI fluorescence. Development conditions were identical for all microphotographs. 
PO staining was performed as described by Graham and Karnowsky (1966), using 0.1 $M$ imidazole (Merck) in the reaction mixture. After each reaction of $6 \mathrm{~min}$, the cells were rinsed in PBS and counterstained with hematoxylin. For all microphotographs, the same exposure times $(35 \mathrm{sec})$ and development conditions were observed, using the same microscope, a $540 \mathrm{~nm}$ green filter, and Agfapan 25 ASA black-and-white film.

\section{Quantitation of ISH signals}

Quantitation of fluorescent FITC signals was performed using a Biorad MRC 600 confocal scanning laser microscope equipped with an appropriate filter for FITC fluorescence (Arndt-Jovin et al., 1985; Robert-Nicoud et al., 1989). From each preparation, three or four areas were randomly selected and 25 ISH spots were measured. The fluorescence intensities of the ISH signals were corrected for aspecific background reactions by also measuring the fluorescence intensity next to the specific ISH signal areas in the interphase nuclei (background $<5 \%$ of the fluorescence intensities of the specific ISH signals). Furthermore, the specific ISH signal intensities were subjected to the Mann-Whitney test.

\section{RESULTS}

When T24 tumor cells are hybridized with the biotinylated chromosome 1-specific DNA probe pUC 1.77 , this sequence can be detected simply by using one incubation step of AvFITC (Reaction 1, Table 1). This results in three fluorescent signals (spots) as shown in Figure 2a.

Table 1. Quantitative results of different incubation protocols after ISH on T24 cells with the biatinylated DNA probe for chromosome 1 .

\begin{tabular}{|c|c|c|c|c|c|c|}
\hline \multirow[t]{2}{*}{ Reaction } & \multicolumn{4}{|c|}{ Subsequent incubation steps } & \multirow{2}{*}{$\begin{array}{l}\text { Semi-quantitative } \\
\text { interpretation of } \\
\text { FITC fluorescence } \\
\text { intensity }\end{array}$} & \multirow{2}{*}{$\begin{array}{l}\text { Quantitated fluorescence } \\
\text { intensity } \\
\text { (arb units) }\end{array}$} \\
\hline & 1 & 2 & 3 & 4 & & \\
\hline 1 & AvFITC ${ }^{b}$ & & & & + & $30 \pm 15$ \\
\hline 2 & AvFITC & BioGAA & AvFITC & & +++ & $210 \pm 80$ \\
\hline 3 & AvFITC & Bio & BioGAA & AvFITC & +++ & $250 \pm 70$ \\
\hline 4 & AvFrTC & BioGAA & MABio & AvFITC & $+t$ & $90 \pm 60$ \\
\hline
\end{tabular}

+ , positive; ++ , strongly positive; +++ , extremely positive.

${ }^{b}$ Abbreviations used: AvFITC, FITC-conjugated avidin; Bio, biotin; BioGAA, biotinylated goat antiavidin; MABio, mouse anti-biotin. 

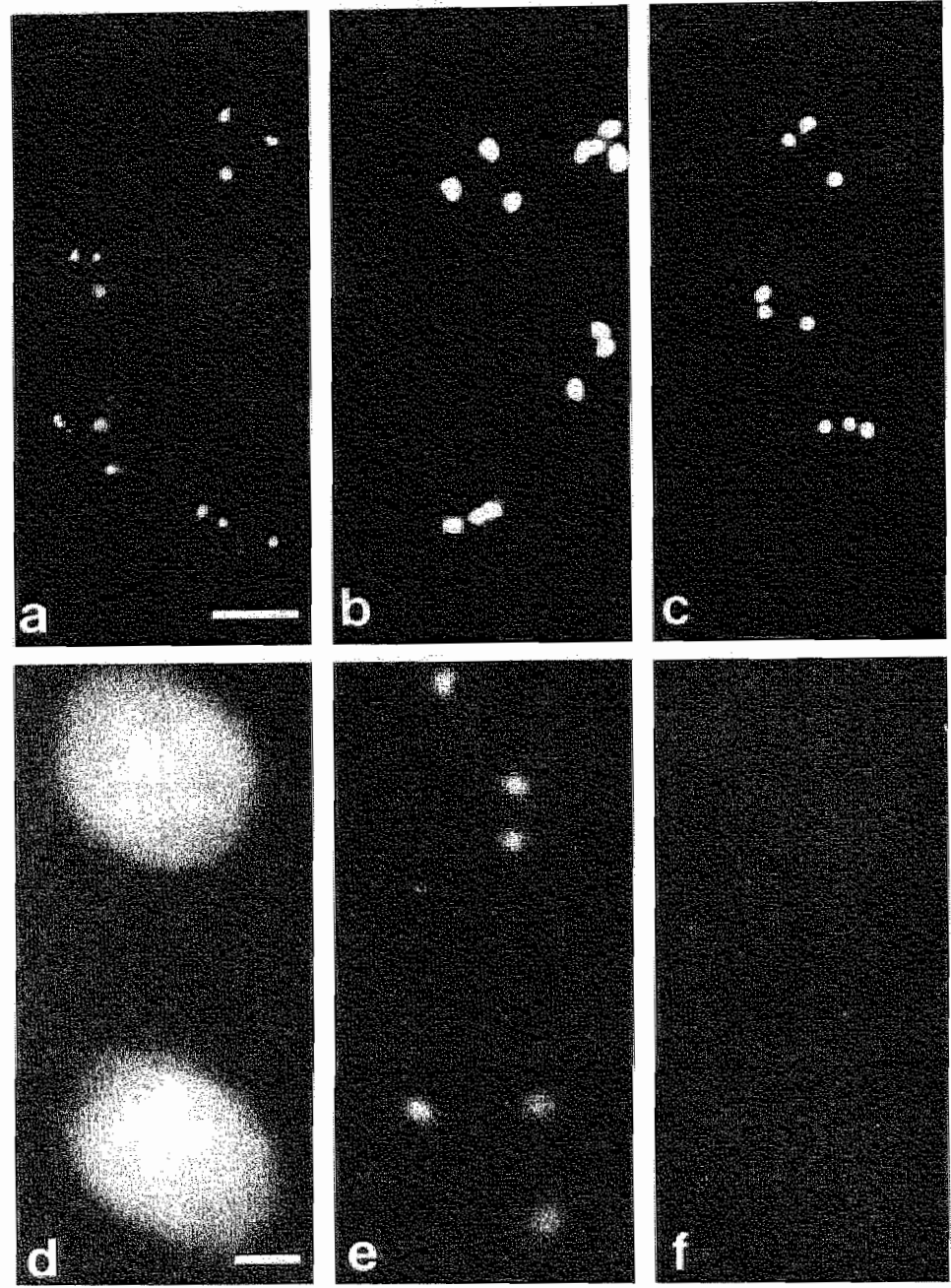

Nigure 2. Results of ISH on T24 cells with the biotinylated DNA probe showing trisony for chromosome 1. (a) Detection after one incubation step with AvFITC (see Table 1, Reaction 1). (b) Amplification of the fluorescence signal intensity as seen in a by introducing BioGAA into the second incubation step and AvFITC into the third incubation step (see Table 1, Reaction 2). (c) Decrease of the fluorescence signal intensity as seen in by introducing MABio in the third incubation step (see Table 1, Reaction 4). (d) DAPI fluorescence of nuclei after performing Reaction 3, Table 2. (e) TRITC fluorescence as a result of Reaction 3, Table 2. (f) FITC fluorescence as a result of Reaction 3, Table 2. Bars: $a-c=20 \mu \mathrm{m} ; \mathrm{d}-\mathrm{f}=5 \mu \mathrm{m}$. 
Table 2. Semi-quantitative results of different incubation protocols after ISH on T24 cells with the biorimylated DNA probe for chromosome 1 .

\begin{tabular}{|c|c|c|c|c|c|c|}
\hline \multirow[t]{2}{*}{ Reaction } & \multicolumn{4}{|c|}{ Subsequent incubation steps } & \multicolumn{2}{|c|}{$\begin{array}{l}\text { Semi-quantitative interpretation } \\
\text { of fluorescence intensity }\end{array}$} \\
\hline & 1 & 2 & 3 & 4 & FITC & TRLTC \\
\hline 1 & AvTRTTC $^{b}$ & BioGAA & MABio & RAMFITC & $+t$ & + \\
\hline 2 & AVTRITC & Buffer & MABio & RAMFITC & - & + \\
\hline 3 & AVTRITC & BioGAR & RAMFITC & & - & + \\
\hline 4 & AVTRITC & BioHAM & MABio & RAMFITC & - & + \\
\hline
\end{tabular}

a - , negative; + , positive; ++ , strongly positive.

Abbreviations used: BioGAR, biotinylated goat anti-rabbit $\operatorname{lgG}_{3}$ BioHAM, biotinylated horse antimouse IgG; RAMFTTC, FITC-conjugated rabbit anti-mouse IgG (see also table $1^{\mathrm{b}}$ ).

"Dilution buffer as described in "Materials and Methods".

\section{AvFITC/BioGAA amplification system}

The ISH signals can be intensified by introducing BioGAA antibodies and AvFITC in a second and third incubation step, respectively (Figure 2b; Reaction 2, Table 1). This is in principle the amplification method as first described by Pinkel et al. (1986) (see Figure 1), which results in an increase of fluorescence intensity with a factor of 7-8 as compared with the one-step incubation procedure with AvFITC.

The nature of the interaction of BioGAA with the first detection layer of AvFITC was studied in two reactions (Reactions 3 and 4, Table 1). First, biotin was introduced in the second incubation step, before introduction of BioGAA and AvFITC, to block any free biotin binding sites of AvFITC (Reaction 3, Table 1; see also Figure 1). This blocking step did not lead to a significant change in FITC fluorescence intensity. Second, MABio antibodies were introduced as the third incubation step, before introduction of AvFITC, to block any free biotin moieties of the BioGAA antibodies (Reaction 4, Table 1; see also Figure 1). This interaction resulted in a significant decrease of the fluorescence intensity as compared with Reaction 2 (see Figure 2c). However, the fluorescence intensity was still increased with a factor of $3-4$ as compared with Reaction 1.

Incorporation of the MABio antibodies into the complex was demonstrated by using RAMFITC antibodies (Reaction 1, Table 2), in which the ISH signal intensity was interpreted in a semi-quantitative way. In a control reaction we showed, that the FITC fluorescence was not the result of the direct binding of MABio antibodies to the biotinylated DNA probe (Reaction 2, Table 2). We further studied the limitations of the avidin molecules in the first detection layer to couple other biotinylated antibodies, using two different fluorochrome-labeled molecules (Reactions 3 and 4 , Table 2). As shown in these reactions, no direct interaction of the biotinylated antibodies with AvTRITC could be detected with RAMFITC in a final step (Figures $2 \mathrm{~d}-2 \mathrm{f}$ ). 
These experiments suggest that the cytochemical complex, as build up following Reaction 2 in Table 1 , is independent of the interaction of the biotin moieties of BioGAA with the firstly coupled AvFITC molecules. Furthermore, these studies show, that the biotin groups in BioGAA are free for interaction with AvFITC in a subsequent incubation step (Reactions 2-4, Table 1).

\section{Comparison of different ISH detection procedures}

Thus far, we have found that there exist limitations in the coupling of biotinylated molecules to avidin molecules in the first detection layer. Therefore, we expect that this phenomenon also has consequences for other ISH detection systems in which avidin-biotin interactions play an important role, e.g., the sensitive ABC method (Hsu et al., 1981; Brigati et al., 1983). For this reason, we performed ISH reactions in which the biotinylated probe was detected with different cytochemical staining systems using (a) AvPO, (b) avidin, (c) BioPO, or (d) a complex of avidin and BioPO $(A B C)$. The results of these reactions are summarized in Table 3. In Figure 3 the results from the reactions summarized in Table 3 are depicted and arranged according to increasing $\mathrm{PO}$ staining intensity. Reactions $1-4$ in Table 3 demonstrate that the use of AvPO was superior as compared with the detection system using avidin and a subsequent step of BioPO. This was found for the direct detection of the probe (Reactions 1 and 2, Table 3 ) as well as for the indirect detection after introduction of BioGAA (Reactions 3 and 4, Table 3). Furthermore, the AvPO/BioGAA amplification system using two AvPO incubation steps (Reaction 5, Table 3) resulted in a stronger staining intensity as compared with Reaction 4 in table 3 .
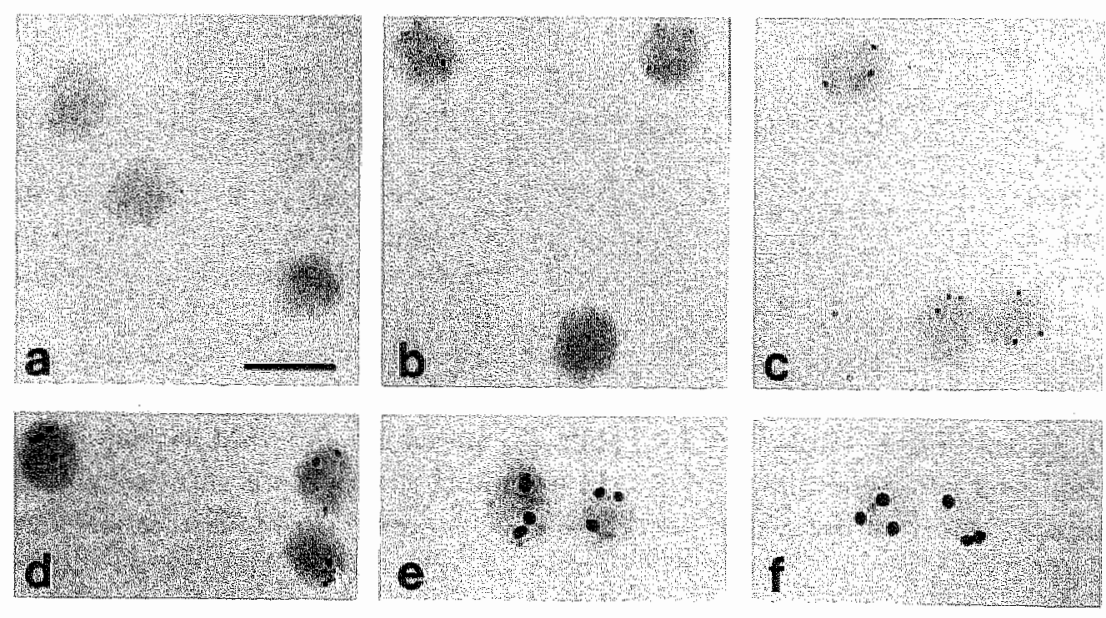

Figure 3. ISH results showing trisomy for chromosome 1 in $\mathrm{T} 24$ cells, using different detection protocols and PO staining reactions as summarized in Table 3. (a-f) The different photographs are ordered according to increasing staining intensity. (a) Detection after performing Reaction 1; (b) Reaction 6; (c) Reaction 3; (d) Reaction 2; (e) Reaction 8; (f) Reaction 5. Bar $=20 \mu \mathrm{m}$. 
Table 3. Semi-quantitative data of PO staining intensities in different ISH detection protocols after ISH On 124 cells with the biotinylated DNA probe for chromosome 1.

\begin{tabular}{llcccc} 
Reaction & \multicolumn{3}{c}{ Subsequent incubation steps } & $\begin{array}{c}\text { Semi-quantitative interpretation of } \\
\text { PO staining intensity }\end{array}$ \\
\hline 1 & 1 & 2 & 3 & 4 & $-1 \pm$ \\
2 & Av $^{\mathrm{b}}$ & BioPO & & & $+1++$ \\
3 & AvPO & & & + & ++ \\
4 & Av & BioGAA & Av & BioPO $^{\circ}$ & +++ \\
5 & Av & BioGAA & AvPO & + \\
6 & AvPO & BioGAA & AvPO & $++1+++$ \\
7 & ABC & & & $++1+++$ \\
8 & ABC & BioGAA & ABC & +++ \\
9 & Av & BioGAA & ABC & ++ \\
10 & MABio & BioHAM & ABC & +++ \\
11 & MABio & RAMPO & & \\
\hline
\end{tabular}

a negative; \pm , weakly positive; + , positive; ++ , strongly positive; +++ , extremely positive.

b Abbreviations used: $A B C$, avidin biotinylated horseradish peroxidase ( $P O$ ) complex; $A v_{\text {, avidin; }}$ AvPO, PO-conjugated avidin; BioPO, biotinylated PO; RAMPO, PO-conjugated rabbit antimouse IgG; SWARPO, PO-conjugated swine anti-rabbit IgG (see also Tables 1 and 2).

c When BioPO with a long $\mathrm{C}_{10}$ spacer was used (from Boehringer Mannheim), a slightly stronger PO staining intensity was found in Reactions 1 and 3.

The $A B C$ detection system is based on the application of a complex between avidin and BioPO, which is formed before its cytochemical introduction. Reactions 6-9 in Table 3 show, that direct coupling of an $A B C$ complex to the biotinylated DNA probe resulted in a weak PO staining intensity (Reaction 6, Table 3), whereas application of the three-step procedures with a biotinylated antibody as the second reagent resulted in strong PO staining with only minor differences in intensity (Reactions 7-9, Table 3). Reaction 9 is the most commonly used $\mathrm{ABC}$ reaction for cytochemistry.

The sensitivity of all procedures used was compared with the sensitivity of an indirect ISH detection system using MABio antibodies and PO-conjugated second and third antibodies (Reactions 10 and 11, Table 3). In our hands, the sensitive ISH detection methods stated in Reactions 5, 9 and 11 differed only slightly in PO staining intensity. 


\section{DISCUSSION}

Our experiments show that the AvFITC/BioGAA amplification procedure is a sensitive non-radioactive ISH detection system. The fluorescence signal intensity after the detection of a biotinylated DNA probe with AvFITC can be increased seven- or eightfold by subsequent incubation steps with BioGAA and AvFITC. This finding is in agreement with the results of Pinkel et al. (1986), who found a sixfold intensity increase as a result of this amplification reaction.

We have meticulously studied the individual steps in the AvFITC/BioGAA amplification procedure to obtain more insight into the molecular basis of cytochemical network formation in which avidin-biotin interactions play an important role. Our experiments demonstrate, that the interaction of the biotin groups of BioGAA with AvFITC in the first detection layer is not essential for the cytochemical network formation, since addition of biotin did not block the introduction of BioGAA. This result suggests, that only cytochemical interactions are responsible for network formation, as illustrated in the righthand part of Figure 1, and that interactions as illustrated in the lefthand part of Figure 1 are unlikely. The finding that other biotinylated antibodies, such as BioGAR and BioHAM, were also unable to bind to avidin molecules in the first detection layer with their biotin groups further supports this assumption.

Therefore, if BioGAA antibodies can only bind with their antigen binding sites to avidin molecules in the first detection layer, the amplification reaction must be the result of the subsequent binding of conjugated avidin molecules to still available free antigen binding sites and/or antibody-linked biotin groups (see arrows 2 and 3, respectively, in Figure 1). This was investigated by the addition of MABio antibodies to block the biotin groups of BioGAA antibodies. As a result, a reduced fluorescence signal. intensity was seen in comparison with the amplification reaction, which was still three- or fourfold higher as compared with the intensity seen in the one-step AvFITC detection. Since one avidin molecule consists of four identical subunits (Green, 1975), the measured fluorescence intensity could be the result of the interaction of maximally four BioGAA antibodies with one first layer AvFITC molecule. Then, one AvFITC molecule per antibody molecule is bound to the other still free antigen binding site (as illustrated in Figure 1, arrow 2). It is also plausible that avidin molecules, which have a much higher affinity for biotin as compared with MABio antibodies, can compete with some bound MABio antibodies, resulting in a more intense fluorescent signal. Nevertheless, the MABio antibodies were coupled to the biotin groups of BioGAA antibodies. This finding suggests, that binding of conjugated avidin as illustrated by arrow 3 (Figure 1) is also an important interaction in the studied amplification method.

In summary, the mechanism of the studied amplification procedure, thus, includes the binding of BioGAA antibodies to first-layer conjugated avidin by means of their antigen binding sites, followed by coupling of conjugated second avidin molecules, as illustated by arrows 2 and 3 in Figure 1. 

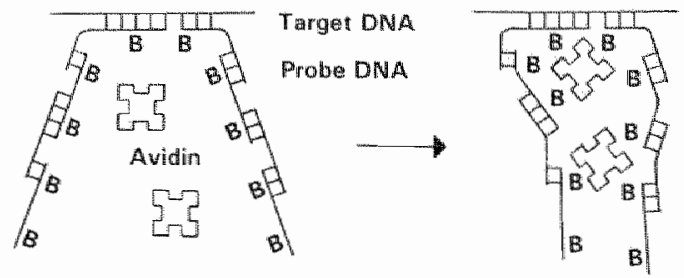

Figure 4. Diagram illustrating "closed network" formation as a result of the binding of avidin with a primary hybridized and biotinylated DNA probe. B, biotin.

Despite this renewed insight into the molecular basis of the AvFITC/BioGAA amplification procedure, the question remains of why it is impossible to couple biotinylated antibodies to avidin molecules in the first detection layer by means of their biotin moieties. Since BioGAA antibodies can bind to these avidin molecules by means of their antigen binding sites, penetration of antibodies to the "ISH detection site" seems not to be the problem. It seems likely, that almost no free biotin binding sites remain available after the interaction of avidin molecules with biotinylated probe molecules.

To explain the experimental data, we propose that a "closed network" is formed by avidin in combination with the biotinylated, primary hybridized DNA probe, as illustrated in Figure 4. As a result, most of the biotin binding sites of avidin in the first detection layer are blocked, while others may be sterically hindered and difficult for biotinylated macromolecules to reach. In our view this "closed network" is formed, since biotinylated non-target-specific plasmid sequences of the probe also hybridize with each other and, thus, contribute to the ultimately formed complex.

These new insights are supported by the fact that defection of the biotinylated chromosome 1-specific probe by $\mathrm{PO}$ staining is much less efficient using two subsequent incubation steps of avidin and BioPO as compared with the use of one incubation step using AvPO only. A similar quantitative difference in detection efficiency also exists between the use of alkaline phosphatase (APase)-conjugated avidin alone as compared with the application of avidin followed by a second step of biotinylated APase (with a long $\mathrm{C}_{10}$ spacer; Boehringer), which was negative in a APase-Fast Red staining procedure (data not shown).

The use of avidin molecules in the third incubation step also results in a situation, where only a limited number of free biotin binding sites are available for interaction with biotinylated molecules such as BioPO in a following incubation step. Again, the better result proceeds from direct coupling of, e.g., AvPO or the ABC complex to the biotinylated secondary antibodies. Thus, in cytochemical networks with avidin-biotin interacting layers used for the amplification of DNA hybrid detection, avidin molecules cannot be efficiently used to interconnect two biotinylated layers, because the introduction of avidin molecules leads to firmly closed networks, as illustrated in Figure 4. Despite this phenomenon, the AvFITC/BioGAA amplification method still proves to be an efficient ISH detection method as a result of the immunoreactivity of 
the BioGAA antibodies. These antibodies contribute to the extreme stability of the formed network, since it was impossible to dissociate the coupled antibodies from the network with $0.1 \mathrm{M}$ glycine-HCl, $\mathrm{pH} 2.8$, or $1.5 \mathrm{M} \mathrm{NaSCN}$ (unpublished data).

The three-step $A B C$ detection systems appeared to be sensitive methods, in which it was essential to introduce avidin and $\mathrm{BioPO}$ as an $\mathrm{ABC}$ complex onto the biotinylated secondary antibodies. The application of avidin and BioPO in two subsequent incubation steps or the direct coupling of the $A B C$ complexes to the hybridized and biotinylated DNA probe results in much weaker ISH signals. The latter finding suggests, that penetration problems play an important role in the use of $A B C$ complexes. Most probably, both low molecular weight complexes and avidin molecules, which are byproducts of the $A B C$ complex formation reaction, are responsible for the weak ISH signal in Reaction 6 of Table 3.

Comparison of the three most frequently used sensitive ISH detection assays (Reactions 5, 9, and 11 of Table 3) showed no significant differences in PO staining. intensity. Although we have studied the detection of a highly repetitive DNA sequence on chromosome 1 using different detection systems, it was obvious that the order of introduction of conjugated avidin molecules, biotinylated molecules, and complexes of both in a detection system, as well as penetration problems of the cytochemical reagents used, influenced the formation of cytochemical networks. The unraveling of the molecular basis of routinely used ISH detection procedures will in the future provide us with crucial data, that will enable us to choose the proper procedures for increasing the sensitivity, and possibly also the specificity, of cytochemical tests. The results presented in here may be a first step in that direction.

\section{Acknowledgements}

This work was supported by the Foundation for Medical Health Research (Medigon), grant no. 900534-073.

\section{REFTRENCES}

Albertson DG, Fishpool $\mathbb{R}$, Sherrington $P$, Nacheva $E$, Milstein $C$ (1988) Sensitive and high resolution in situ hybridization to human chromosomes using biotin labelled probes." assignment of the human thymocyte CDI antigen genes to chromosome 1. EMBO J 7:2801-2805

Arndt-Jovin DJ, Robert-Nicoud M, Baurschmidt $P$, Jovin TM (1985) Immunofluorescence localization of Z-DNA in chromosomes: quantitation by scanning microphotometry and computer" assisted image analysis. J Cell Biol 101:1422-1433

Bakkus MHC, Brakel-Van Peer KMJ, Adriaansen HJ, Wierenga-Wolf AF, Van den Akker TW, Dicke-Evinger MJ, Benner R (1989) Detection of oncogene expression by fluorescent in situ hybridization in combination with immunofluorescent staining of cell surface markers. Oncogene $4: 1255-1262$

Böck $G$, Hilchenbach M, Schawenstein $\mathrm{K}$, Wick $\mathrm{G}$ (1985) Photometric analysis of antifading reagents for immunoffuorescence with laser and conventional illumination sources. I Histochem Cytochem $33: 699-705$ 
Bresser J, Evinger-Hodges MJ (1987) Comparison and optinization of in situ liybridization procedures yielding rapid, sensitive mRNA detections. Gene Anal Technol 4:89-104

Brigati DJ, Myerson D, Leary JJ, Spalholz B, Travis S, Fong CKY, Hsiung GD, Ward DC (1983) Detection of viral genomes in cultured cells and paraffin-embedded tissue sections using biotinlabeled hybridization probes. Virology 126:32-50

Bubeník J, Baresôvã V, Viklicky V, Jakoubkova J, Sainerova H, Donner J (1973) Established cell line of urinary bladder carcinoma (T24) containing tumour-specific antigen. Int I Cancer 11:765-773

Cherif D, Julier C, Delattre O, Lathrop GM, Berger R (1990) Simultaneous localization of cosmids and chromosome $\mathrm{R}$-banding by fluorescence microscopy: application to regional mapping of human chromosome 11. Proc Nat] Acad Sci USA 87:6639-6643

Cooke HJ, Hindley J (1979) Cloning of human satellite III DNA: different components are on different chromosomes. Nucleic Acids Res 6:3177-3197

Fan Y-S, Davis LM, Shows TB (1990) Mapping small DNA sequences by fluorescence in situ hybridization directly on banded metaphase chromosomes. Proc Natl Acad Sci USA 87:6223-6227

Garson JA, Van den Berghe JA, Kemshead IT (1987) Novel non-isotopic in situ hybridization technique detects small ( $1 \mathrm{~kb}$ ) unique sequences in routinely G-banded human chromosomes: fine mapping of N-myc and $\beta$-NGF genes. Nucleic Acids Res 15:4761-4770

Graham RC, Karnovsky MJ (1966) The early stages of absorption of injected horseradish peroxidase in the proximal tissues of mouse kidney with structural cytochemistry by a new technique. $J$ Histochem Cytochem 14:291-302

Green NM (1975) Avidin. Adv Protein Chem 29:85-133

Haase AT, Retzel EF, Staskus KA (1990) Amplification and detection of lentiviral DNA inside cells. Proc Natl Acad Sci USA 87:4971-4975

Hopman AHN, Ramaekers FCS, Raap AK, Beck JLM, Devilee P, Van der Ploeg M, Vooijs GP (1988) In situ hybridization as a tool to study numerical chromosome aberrations in solid bladder tumors. Histochemistry $89: 307-316$

Hsu S-M, Raine L, Fanger $H$ (1981) Use of avidin-biotin-peroxidase complex (ABC) in immunoperoxidase techniques: a comparison between $\mathrm{ABC}$ and unlabeled antibody (PAP) procedures. J Histochem Cytochem 29:577-580

Landegent JE (1987) In situ hybridization using 2-acetylaminefluorene-modified nucleic acid probes. Thesis, University of Leiden, The Netherlands. Amsterdam, K and L Grafic Productions

Lawrence IB, Villnave CA, Singer RH (1988) Sensitive, high-resolution chromatin and chromosome mapping in situ: presence and orientation of two closely integrated copies of EBV in a lymphoma line. Cell $52: 51-61$

Lichter P, Cremer T, Chang Tang C-J, Watkins PC, Manuelidis L, Ward DC (1988) Rapid detection of human chromosome 21 aberrations by in situ hybridization. Proc Natl Acad Sci USA 85:96649668

Lichter P, Chang Tang C-J, Call K, Hermanson G, Evans GA, Housman D, Ward DC (1990) Highresolution mapping of human chromosome 11 by in situ hybridization with cosmid clones. Science $247: 64-69$ 
Pinkel $\mathrm{D}$, Straume $\mathrm{T}$, Gray JW (1986) Cytogenetic analysis using quantitative, high sensitivity fluorescence hybridization. Proc Natl Acad Sci USA 83:2934-2938

Robert-Nicoud M, Arndt-Jovin DJ, Schormann T, Jovin TM (1989) 3-D Imaging of cells and tissues using confocal laser scanning microscopy and digital processing. Eur J Cell Biol 48 (Suppl 25):49m52

Tkachuk DC, Westlorook CA, Andreeff $M$, Donlon TA, Cleary ML, Suryanarayan K, Homge $M$, Redner A, Gray $\mathbf{J}$, Pinkel D (1990) Detection of ber-abl fusion in chronic myelogeneous leukemia by in situ hybridization. Science 250:559-562

Viegass-Pequignot $\mathrm{E}_{\text {, }}$ Dutrillaux $\mathrm{B}$, Magdelenat $\mathrm{H}_{*}$ Coppey Moisan $\mathrm{M}$ (1989) Mapping of single-copy DNA sequences on human chromosomes by in situ hybridization with biotinylated probes: enhancement of detection sensitiwity by intensified-fluorescence digital-imaging microscopy. Proc Natl Acad Sci USA $86: 582-586$ 


\title{
CHAPTER 3
}

\section{A NOVEL FLUORESCENCE DETECTION METHOD FOR IN SITU HYBRTDIZATION, BASED ON THE ALIKALINE PHOSPHATASE-FAST RED REACTION}

\author{
Ernst JM Speel, Bert Schutte, Joop Wiegant, Frans CS Ramaekers, \\ Anton HN Hopman
}

J Histochem Cytochem 40, 1299-1308, 1992

\begin{abstract}
We have used naphthol-ASMX-phosphate and Fast Red TR in combination with alkaline phosphatase (APase) to produce fluorescent precipitated reaction products in a non-radioactive in situ hybridization (ISH) method. To obtain optimal and discrete localization of the strongly red fluorescent ISH signals, the enzyme precipitation procedure was optimized. The optimal reaction time and the concentrations of substrate and capture agent were determined. Furthermore, polyvinyl alcohol was used to increase the viscosity of the reaction mixture and thus to reduce diffusion of the reaction product. Our results show, that the APase-Fast Red detection method has at least the same sensitivity as currently observed in other immunofluorescence detection systems. A single-copy DNA sequence of $15.8 \mathrm{~kb}$ could be localized with high efficiency in metaphase spreads and in interphase nuclei. Double labeling procedures, in which the fluorescein isothiocyanate (FITC)- and azo-dye fluorescence are combined, are also feasible. The red fluorescent ISH signals showed hardly any fading as compared with FITC fluorescence on exposure to either light from the mercury-arc lamp or laser light. Therefore, these red fluorescent signals with a virtually permanent character allow a better analysis and three-dimensional localization of such cytochemically detected genomic fractions by means of confocal scanning laser microscopy as compared with the use of FITC, or Texas Red as label.
\end{abstract}




\section{INTRODUCTION}

Non-radioactive in situ hybridization (ISH) is a powerful technique to detect target DNA sequences up to the level of single-copy genes of 1-6 kb (Garson et al., 1987; Lawrence et al,, 1988; Viegas-Pequignot et al., 1989; Trask, 1991). The sensitivity of this technique is now comparable to the sensitivity of radioactive procedures. Furthermore, non-radioactive ISH has advantages over radioactive ISH owing to its better spatial resolution, probe stability, and direct results. Since its introduction (Gall and Pardue, 1969; John et al., 1969; Rudkin and Stollar, 1977; Bauman et al., 1980), many non-radioactive detection systems have been described for ISH, including enzyme cytochemical as well as fluorescence procedures (Raap et al., 1989). Most of these methods are based on the detection of in situ hybridized and modified DNA probes with cytochemical layers of either avidin or antibody conjugates. These conjugates can carry fluorescent marker molecules for use in fluorescence microscopy (Nederlof et al., 1989). Furthermore, enzymes, the reaction products of which can be visualized by brightfield microscopy (Garson et al., 1987; Emmerich et al., 1989) or reflection contrast microscopy (Landegent et al., 1985), are being used as reporter molecules. Recently, the application of directly fluorochrome-labeled DNA probes has been described (Morrison and Legator, 1991; Wiegant et al., 1991).

In spite of the high sensitivity which can be obtained with the fluorescence ISH method, this procedure has the disadvantage that rapid fading of the fluorescence signal takes place during excitation (Johnson et al., 1982). This can be the result of bleaching, i.e., the reduction of fluorescence due to photochemical reactions which cause decomposition of the fluorescent molecules, or it can be due to quenching, the reduction of fluorescence owing to the presence of other fluorophores, oxidizing agents, or other compounds that influence the electronic configuration of the fluorophore. Therefore, anti-bleaching reagents are being added to the mounting medium to delay the bleaching process (Böck et al., 1985).

Other non-radioactive methodologies are also being studied, including time-resolved fluorescence microscopy using labels such as europium-activated inorganic phosphors (Beverloo et al., 1990), and chemiluminescence (Bronstein and Voyta, 1989). In spite of the sensitivity that has thus far been obtained with these approaches, their application to ISH is still not a routine procedure.

Recently, the use of naphthol-ASMX-phosphate as substrate and the diazonium salt Fast Red TR as trapping agent for the demonstration of alkaline phosphatase (APase) activity (Murdoch et al., 1990; Ziomek et al., 1990) (further abbreviated as APaseFast Red technique) showed, that the red reaction product was highly fluorescent on excitation by green light $(550 \mathrm{~nm}$ ). From earlier studies (Burstone, 1960; Dolbeare et all., 1980; Raap, 1986) it was known, that fluorescent products could be produced, e.g., by hydrolysis of substituted naphthol-AS-phophates, with or without a trapping agent such as Fast Red TR. As a result of the fluorescent property of the APase-Fast Red reaction product, the sensitivity of antigen detection was enhanced in the fluorescence assay as compared with detection of the reaction product under 
brightfield illumination. Furthermore, the fluorescent character of the red precipitate appeared to be stable on exposure or during storage (Murdoch et al., 1990; Ziomek et al., 1990).

Because of these apparent advantages of the APase-Fast Red technique, we examined its usefulness in ISH procedures. In this report, we define parameters for an accurate localization of fluorescent azo dye precipitate signals and have studied sensitivity and bleaching characteristics in interphase nuclei as well as in metaphase preparations.

\section{MATERIALS AND METHODS}

\section{Cell processing}

Preparation of slides from a cell suspension of the human transitional cell carcinoma line T24 [DNA index 1.6; trisomic for the centromeres of chromosomes 1 and 7; (Bubeník et al., 1973)], as well as steps necessary for removal of cytoplasm to improve DNA probe and conjugate penetration, were performed as previously described (Hopman et al., 1988; Speel et al., 1992). Briefly, $5 \mu l$ of the T24 cell suspension were dropped on poly-L-lysine-coated glass slides, air-dried, and heated at $80^{\circ} \mathrm{C}$ for $1 \mathrm{hr}$. Thereafter, digestion with pepsin from porcine stomach mucosa (2500$3500 \mathrm{U} / \mathrm{mg}$ protein; Sigma, St Louis, MO, USA) was performed at a concentration of $100 \mu \mathrm{g} / \mathrm{ml}$ in $0.01 \mathrm{M} \mathrm{HCl}$ for $20 \mathrm{~min}$ at $37^{\circ} \mathrm{C}$. After five subsequent washes in both demineralized water (Milli Q) and phosphate-buffered saline (PBS; $0.15 \mathrm{M} \mathrm{NaCl}, 10$ $\mathrm{mM} \mathrm{Na}$-phosphate, $\mathrm{pH} 7.2$ ) and fixation in $1 \%$ paraformaldehyde in PBS for $20 \mathrm{~min}$ at $4^{\circ} \mathrm{C}$, the slides were again washed in PBS (five times) and Milli $\mathrm{Q}$ (five times). These preparations were pre-equilibrated in $60 \%$ formamide, $2 \times S S C(0.3 \mathrm{M} \mathrm{NaCl}, 30$ $\mathrm{mM} \mathrm{Na}$-citrate), pH 5.0, containing 0.05\% Tween 20 (Merck, Darmstadt, Germany) for 5 min at room temperature (RT) and washed in $2 x S S C$, pH 7.0 , for 5 min at RT.

\section{Preparation of metaphase spreads}

Phytohemagglutinin-stimulated lymphocytes from a normal adult male $(46, X Y)$ were cultured in 1x chromosome medium (Boehringer, Mannheim, Germany) at $37^{\circ} \mathrm{C}$ for $72 \mathrm{hr}$ and treated for $2 \mathrm{hr}$ with colcemid (Gibco BRL, Breda, The Netherlands) at a concentration of $0.2 \mu \mathrm{g} / \mathrm{ml}$. After centrifugation, cells were re-suspended in a prewarmed $\left(37^{\circ} \mathrm{C}\right)$ swelling buffer containing $50 \mathrm{mM} \mathrm{KCl}, 5 \mathrm{mM} \mathrm{N}$-[2-hydroxyethyl]piperazine-N'-[2-ethanesulfonic acid] (Hepes), $10 \mathrm{mM} \quad \mathrm{MgSO}_{4}$, and $3 \mathrm{mM}$ dithiothreitol, $\mathrm{pH} 8.0$. After incubation for $20 \mathrm{~min}$ at $37^{\circ} \mathrm{C}$, cells were fixed with four changes of methanol/acetic acid $(3: 1 \mathrm{v} / \mathrm{v})$. These cell suspensions were stored at $20^{\circ} \mathrm{C}$ until use. Cells were dropped on ethanol/ether $(1: 1 \mathrm{v} / \mathrm{v})$ cleaned slides and allowed to air-dry. The slides were then treated with $100 \mu \mathrm{g} / \mathrm{ml}$ RNase A (Boehringer) in $2 \times S S C$, pH $7.0^{\circ}$, under a coverslip for $1 \mathrm{hr}$ at $37^{\circ} \mathrm{C}$, followed by three subsequent washes with $2 \times \mathrm{SSC}, \mathrm{pH} 7.0$, for $5 \mathrm{~min}$ at $37^{\circ} \mathrm{C}$. Thereafter, digestion with pepsin was done at a concentration of $100 \mu \mathrm{g} / \mathrm{ml}$ in $0.01 \mathrm{M} \mathrm{HCl}$ under a coverslip for $10 \mathrm{~min}$ at $37^{\circ} \mathrm{C}$. After five dip washes in Milli $\mathrm{Q}$ and two washes in 
PBS and PBS containing $50 \mathrm{mM} \mathrm{MgCl}_{2}$, respectively, for 5 min at $\mathrm{RT}$, the preparations were post-fixed with $1 \%$ formaldehyde in $\mathrm{PBS} / 50 \mathrm{mM} \mathrm{MgCl}_{2}$ for 10 min at RT. After two washes in PBS the slides were dehydrated in ethanol and kept at RT until use.

\section{DNA probes and labeling procedure}

The probes for the (peri)centromeric regions of the human chromosomes 1 (pUC 1.77 ) and 7 (p7t1) have been described by Cooke and Hindley (1979) and Waye et al. (1987). The human 1 p-specific subtelomeric probe p1-79 was described by Buroker et al. (1987). A mixture of 5 single-copy subclones specific for $15.8 \mathrm{~kb}$ of the 3 ' end DNA sequence of the thyroglobulin gene (Van Ommen et al., 1983), located on the distal end of the $\mathrm{q}$ arm of chromosome 8, was used for ISH as described by Landegent et al. (1985). For the single-target ISH procedure, the DNA probes were biotinylated using biotin-11-dUTP (Enzo Diagnostics, New York, NY, USA) in a nick-translation reaction as described by Brigati et al. (1983). For use in the doubletarget ISH procedure, the pUC 1.77 probe was labeled with digoxigenin-11-dUTP (Boehringer) in a nick-translation reaction.

\section{In situ hybridization procedures}

The DNA probes described above were hybridized in single- and double-target ISH in a hybridization buffer containing $60 \%$ formamide, $2 \times S S C, p H 5.0,10 \%$ dextran sulphate, $0.2 \mu \mathrm{g} / \mu \mathrm{l}$ herring sperm DNA as carrier DNA and $0.2 \mu \mathrm{g} / \mu \mathrm{l}$ yeast tRNA as carrier RNA, except for the thyroglobulin probe, which was hybridized in hybridization buffer containing $50 \%$ formamide. In the single-target ISH procedure, we added $10 \mu \mathrm{l}$ buffer to the slides under a coverslip $(20 \times 20 \mathrm{~mm})$, containing $4 \mathrm{ng}$ biotinylated pUC $1.77 \mathrm{DNA}, 10 \mathrm{ng}$ biotinylated $\mathrm{p} 7 \mathrm{t1} \mathrm{DNA}$, or $20 \mathrm{ng}$ biotinylated thyroglobulin gene DNA. For double-target ISH, the buffer contained $4 \mathrm{ng}$ digoxigenin-labeled pUC 1.77 DNA and $10 \mathrm{ng}$ biotinylated p7t1 DNA. Denaturation was performed on the bottom of a metal box in a water bath at $80^{\circ} \mathrm{C}$ for $5 \mathrm{~min}$. Hybridization was performed overnight at $37^{\circ} \mathrm{C}$. Post-hybridization washes were performed twice in 50 or $60 \%$ formamide (depending on the probe used), $2 \times S S C, p H$ 5.0 , containing $0.05 \%$ Tween 20 for $10 \mathrm{~min}$ at $42^{\circ} \mathrm{C}$, twice in $2 \times S S C$, pH 7.0 , for 5 min at $42^{\circ} \mathrm{C}$, and once in $4 \times \mathrm{SSC}, \mathrm{pH} 7.0$, containing $0.05 \%$ Tween 20 (Buffer $\mathrm{A}$ ) for 5 min at RT.

\section{Cytochemical detection procedures}

To reduce background staining, the slides were pre-incubated with $4 \times S S C, \mathrm{pH} 7.0$, containing $5 \%$ non-fat dry milk for $10 \mathrm{~min}$ at RT, followed by dipping in Buffer A. Direct fluorescence detection of the biotinylated DNA probes was performed with 1:100 dilutions of fluorescein isothiocyanate (FITC)-conjugated avidin (AvFITC, 5 $\mathrm{mg} / \mathrm{ml}$ stock) or Texas Red-conjugated avidin (AvTxRED). ISH signals were amplified with a 1:100 dilution of biotinylated goat anti-avidin (BioGAA), followed by a second layer of AvFITC or AVTXRED (all from Vector, Brunschwig Chemie, Amsterdam, The Netherlands). For fluorescent APase-Fast Red detection of the 
biotinylated DNA probes, the slides were subsequently incubated with layers of (a) APase-conjugated avidin (AvAPase, $0.4 \mathrm{mg} / \mathrm{ml}$ stock, I:100 diluted) (Dakopatts, Glostrup, Denmark), BioGAA, and AvAPase, or (b) mouse anti-biotin (MABio, 1:100) (Dakopatts), biotinylated horse anti-mouse IgG (BioHAM, 1:200) (Vector), and an avidin biotinylated APase complex (Av/BioAPase) (Boehringer) used according to the manufacturer's instructions. After double-target ISH, first the biotinylated probe was detected with two layers of AvAPase (see above), followed by incubation with mouse monoclonal anti-digoxin (MADig, 1:2000) (Sigma) and FITCconjugated rabbit anti-mouse IgG (RAMFITC, 1:100) (Dakopatts). All the avidin conjugates and BioGAA were diluted in Buffer $\mathrm{A}$, the antibody conjugates were diluted in PBS containing $0.05 \%$ Tween 20 (Buffer B) and $2 \%$ normal rabbit serum, and the Av/BioAPase complex was formed and used in 4xSSC, pH 7.0. After each incubation step, the slides were rinsed twice in the appropriate dihution buffer (without serum) for $5 \mathrm{~min}$ at RT. For the fluorescence approach, the slides were dehydrated and mounted in PBS/glycerol $(1: 9 \mathrm{v} / \mathrm{v})$ containing $2.3 \%$ of the antibleaching reagent 1,4-di-azobicyclo-(2,2,2,)-octane (DABCO) (Sigma) and $0.5 \mu \mathrm{g} / \mathrm{ml}$ of either the nuclear DNA stain 4',6-diamino-2-phenyl indole (DAPI) (Sigma) or propidium iodide (PI) (Sigma). Microphotographs were made on Kodak Tmax 400 ASA color film, using a Leitz Dialux $20 \mathrm{~EB}$ microscope equipped with a $50 \mathrm{~W}$ mercury-arc lamp and appropriate filter sets for FITC/PI, TXRED/PI, and DAPI fluorescence. Exposure times were approximately $15 \mathrm{sec}$ for FITC and APase-Fast Red precipitate fluorescence and $1 \mathrm{sec}$ for DAPI fluorescence.

Microphotographs from APase-Fast Red precipitate absorption staining were taken with the same microscope using a 540-nm green filter and Agfapan 25 ASA blackand-white film.

\section{Alkaline phosphatase cytochemistry}

After incubation with the APase conjugates and two washing steps with PBS for 5 min each at RT, the APase activity was demonstrated with an azo dye coupling technique (Burstone, 1960). To obtain acceptable localization of ISH signals, different approaches and staining times were used for comparison (see Table 1). The standard protocol was performed with a stain solution containing $4 \mathrm{ml}$ of $0.2 \mathrm{M}$ Tris $-\mathrm{HCl}$ buffer, $\mathrm{pH} 8.5$, containing $10 \mathrm{mM} \mathrm{MgCl}$ and $5 \%$ polyvinyl alcohol (PVA; $M$ 40,000) (Sigma), $1 \mathrm{mg}$ of naphthol-ASMX-phosphate (Sigma) in $250 \mu \mathrm{l}$ buffer without PVA, and $5 \mathrm{mg}$ of Fast Red TR salt (Sigma) in $750 \mu$ l buffer without PVA. This stain solution was then gently mixed and used immediately. Filtering through Whatman filter paper was performed for the solutions without PVA, but was omitted for the PVA containing solutions. No negative effect was observed by omitting this step. Slides were incubated with $100 \mu \mathrm{l}$ stain solution under a coverslip for $15 \mathrm{~min}$ at RT and then washed three times with PBS for 5 min at RT. Reaction periods longer than 30 min were avoided, since diazonium salts such as Fast Red TR are unstable in alkaline buffers (Lojda, 1976). The slides were air-dried and mounted as described above (without dehydration) using the DABCO/DAPI mounting solution. 


\section{Quantitation of fuorescent ISH signals}

The Biorad MRC 600 confocal scanning laser microscope was used to quantitate the fluorescence intensities by measuring 25 selected ISH signals (Arndt-Jovin et al., 1985; Robert-Nicoud et al., 1989; Speel et al., 1992). The microscope was equipped with a krypton-argon mixed gas laser with two separate wavelengths for the excitation of FITC (488 nm) and TxRED $(568 \mathrm{~mm})$. The latter was also used for excitation of the APase-Fast Red reaction product. A 3\% neutral density filter was placed in the laser light pathway to reduce light intensity. After 30 scans of $0.3 \mu \mathrm{m}$ ( $\mathrm{Z}$ direction) from a microscope field $(1 \mathrm{scan} / \mathrm{sec})$, the obtained images were visualized twodimensionally and processed using the Biorad MRC 600 working station.

\section{Bleaching of FITC and APase-Fast Red ISH signals}

In each bleaching experiment, the fluorescence intensities of the ISH signals of four nuclei were quantitated as described above. The nuclei were subjected to either blue light (FITC signals) or green light (APase-Fast Red signals) from the mercury-arc lamp for various periods of time. At certain intervals the ISH signal intensities were quantitated. The average fluorescence intensities of the muclei were corrected for background and standard deviations were callculated. Furthermore, the effect of $3 \%$, $10 \%$, and $100 \%$ laser transmission $(0.15,0.5$, and $5 \mathrm{~mW}$ laser light, respectively) (G. Husson, Biorad, personal communication) on the bleaching of FITC and APaseFast Red fluorescence was studied in the same way as described above for the mercury-arc light.

\section{RESULTS}

From the literature, some indications exist that the precipitated APase-Fast Red reaction product has fluorescent properties. This phenomenon was further explored and the reaction was optimized and quantitated.

\section{Optimizing the APase-Fast Red detection system}

To adapt the APase-Fast Red technique for use in fluorescence ISH, several known reaction protocols were tested in a model system consisting of T24 cells in combination with the biotinylated DNA probe for the centromere of chromosome 1, which was detected with AvAP (Table 1). The discreteness of localization and fluorescence intensity of the three APase-Fast Red signals, as well as the background fluorescence in the nuclei, were visually interpreted and scored by comparing these results with a cytochemical FITC detection procedure of the same probe (Figure la). Procedure 1 in Table $\mathbb{1}$ shows that the use of high concentrations of naphthol-ASMXphosphate and Fast Red TR leads to highly fluorescent ISH signals in T24 nuclei, using a filter set specific for TxRED fluorescence. However, these fluorescent APaseFast Red ISH signals showed a poor localization and, as a result, a strongly fluorescent staining throughout the entire nucleus (Figure 1b). In contrast, visualization in brightfield microscopy showed a well-localized trisomy for the 


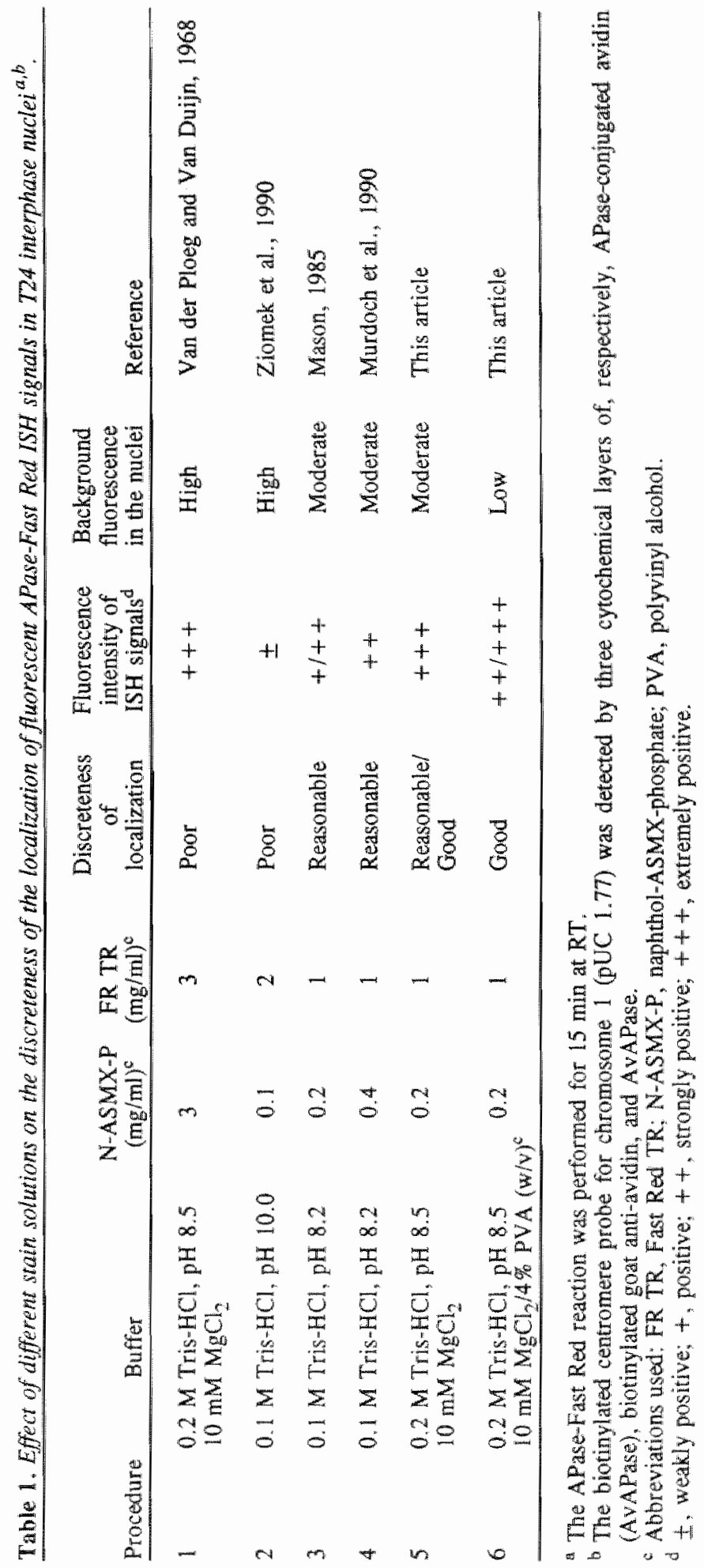



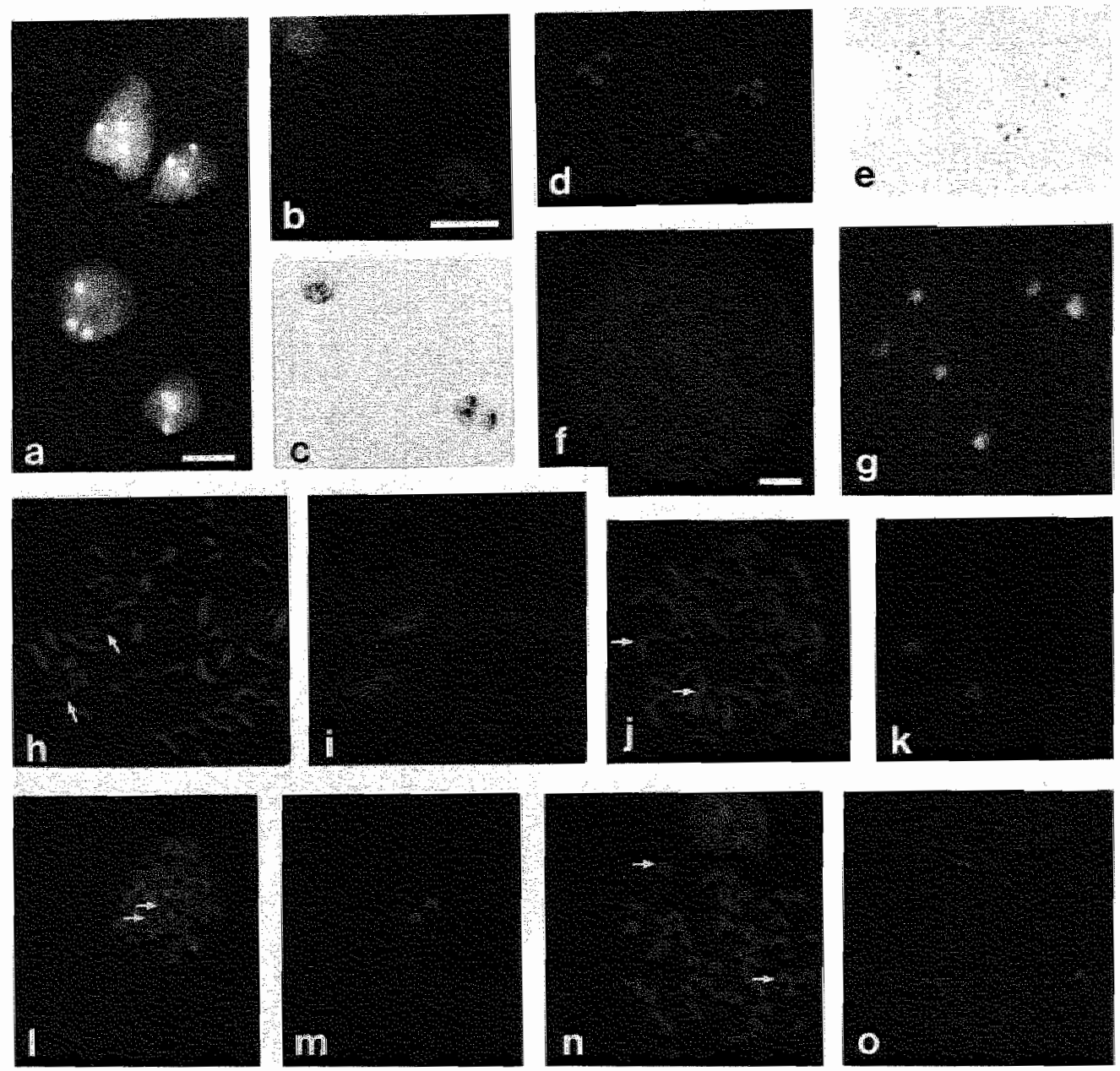

Figure 1. (a-e, h-o) Single-target and $(f, g)$ double-target ISH results in T24 cells (a-g), which contain a trisomy for the centromeres of chromosomes 1 and 7 , and normal human lymphocyte metaphase chromosomes (h-0) with the biotinylated probes pUC 1.77 (a-e, h-k), pl-79 (l,m), thyroglobulin $(\mathbf{n}, 0)$, and $\mathrm{p} 7 \mathrm{t} \mathbf{1}$ in combination with the digoxigenin-labeled pUC 1.77 probe $(\mathrm{f}, \mathrm{g})$. (a) Detection of chromosome 1 centromeres after incubation with two layers of AvFITC. (b) APase-Fast Red fluorescence detection after performing Procedure 1, Table 1. (c) Brightfield detection of the same microscope field as seen in b. (d) APase-Fast Red fluorescence detection of chromosome 1 centromeres after performing Procedure 6, Table 1. (e) Brightfield detection of the same microscope freld as seen in $d$. (C) DNA staining of the same nucleus as seen in $g$ with DAPI fluorescence. (g) Fluorescence detection of the probes pUC 1.77 (digoxigenin-labeled) and p7t1 (biotin-labeled) with FITC (detection with MADig and RAMFITC) and APase-Fast Red (detection with Procedure 6, Table 1), respectively, using the FITC filter set. (h) DNA staining of the same microscope field as seen in i with DAPI fluorescence. (i) APase-Fast Red fluorescence detection of chromosome 1 centromeres after performing Reaction 3, Table 2. (j) DNA staining of the same microscope field as seen in $k$ with DAPI fluorescence. (k) APase-Fast Red fluorescence detection of chomosome 1 centromeres after performing Reaction 2, Table 2. (I) DNA staining of the same microscope field as seen in $m$ ith DAPI fluorescence. (m) APase-Fast Red fluorescence detection of chromosome 1 telomeres after performing Reaction 5, Table 3. (n) DNA staining of the same microscope field as seen in o with DAPI fluorescence. (o) APase-Fast Red fluorescence detection of the thyroglobulin probe after performing Reaction 6 , Table 3. Bars: $a=10 \mu \mathrm{m} ; \mathrm{b}-\mathrm{e}=20 \mu \mathrm{m} ; \mathrm{f}-0=5 \mu \mathrm{m}$. 
centromere of chromosome 1 in the same nuclei (compare Figures 16 and 10). To improve the discreteness of localization of the fluorescent APase-Fast Red signals, several reaction conditions were tested in which concentrations of naphthol-ASMXphosphate and Fast Red TR, as well as the incubation buffer composition and $\mathrm{pH}$, were modified (Procedures 2-6, Table 1). We found, that reduction of the concentrations of both substrate and trapping agent results in a less diffuse appearance of the signals. Optimal APase-Fast Red reaction conditions were seen in $0.2 \mathrm{M}$ Tris$\mathrm{HCl}$, pH 8.5, buffer containing $10 \mathrm{mM} \mathrm{MgCl}$. The addition of PVA to the stain solution, as was suggested by Van Noorden and Vogels (1989) to reduce diffusion of the APase-Fast Red reaction product, further improved the discreteness of localization of the APase-Fast Red ISH signals and lowered the background fluorescence in the nuclei. Therefore, in our hands, Procedure 6 (Table 1) was the most optimal staining reaction for the visualization of clearly localized, distinct red fluorescent ISH signals in T24 nuclei (Figure 1d). When observed with brightfield microscopy, this procedure leads to smaller and weaker red-colored APase-Fast Red ISH signals (Figure le) in comparison with the signals seen in Figure 1c. The procedures described above were all performed for $15 \mathrm{~min}$ at RT. The same findings were also observed on metaphase preparations of normal human lymphocytes.

To examine the effect of this incubation time on the discreteness of localization and fluorescence intensity of the signals, increasing incubation periods were chosen, as shown in Table 2 (Reactions 1-3). A staining reaction for $15 \mathrm{~min}$ at RT appeared to be optimal for a distinct localization, a high fluorescence intensity of the ISH signals, and a low background fluorescence in the nuclei. Longer incubation periods did not result in a further increase of the fluorescence intensity of the spots, although there was an obvious increase of red precipitate observed by brightfield microscopy.

\section{Dowble-target ISH with the APase-Fast Red detection system}

Detection with the APase-Fast Red fluorescence technique could be combined with FITC fluorescence detection in a double-target ISH experiment to demonstrate the presence of a biotinylated and a digoxigenin-labeled probe simultaneously in $T 24$ nuclei (Figures if and $1 \mathrm{~g}$ ). Both the three green (trisomy for chromosome 1 centromere) and the three orange (trisomy for chromosome 7 centromere) signals can be observed simultaneously by using filters specific for FITC fluorescence. The APase-Fast Red signals, thus, show a more orange fluorescence of minor intensity as compared with the red fluorescence seen with the TxRED filter setting. Such a double fluorescence experiment was also performed by Matsuno et al. (1989) to locallize antibody-forming cells in combination with antigens. With the UV filler setting we observed no APase-Fast Red fluorescence.

\section{Sensitivity of the APase-Fast Red detection system}

For application of the APase-Fast Red technique to ISH on metaphase preparations of normal human lymphocytes, a 30 -min incubation period resulted in a poor localization of the fluorescent ISH signals (see Figures $1 \mathrm{~h}$ and $1 \mathrm{i}$, and Reaction 3, Table 2). Instead of a staining reaction only in the centromere site of chromosome 1, both 
chromosomes were completely stained after the APase-Fast Red reaction (Figure 1i). A reduction of the incubation period to $15 \mathrm{~min}$ resulted in an accurate localization of the APase-Fast Red fluorescence to the centromeres of chromosome 1 (Figures $1 \mathrm{j}$ and $1 \mathrm{k}$, and Reaction 2, Table 2). Brightfield microscopy showed the same feature as was seen for the interphase nuclei, i.e., the centromere sites on chromosome 1 were clearly visible as a dark red color and were localized after an incubation period of 15 and 30 min (data not shown).

The sensitivity of the APase-Fast Red technique was determined by two different approaches: (a) by reducing the concentration of the centromere 1-specific probe pUC 1.77 , and (b) by using probes which detect smaller DNA target sequences, such as the subtelomeric probe for chromosome 1 (p1-79) and the single-copy thyroglobulin probes of $15.8 \mathrm{~kb}$. These biotinylated probes were detected with the APase-Fast Red technique, which was compared with a sensitive FITC fluorescence procedure (Table 3).

\section{Reduction of the probe concentration}

Hybridization with decreasing concentrations of the centromere probe for chromosome 1 resulted in a reduced intensity of APase-Fast Red fluorescence comparable with the results obtained with the FITC fluorescence procedure (Reactions 1-4, Table 3). Despite the observation of fluorescent APase-Fast Red ISH signals at a probe concentration of $4-8 \mathrm{pg} / \mu \mathrm{l}$, the same signals could, however, hardly be detected with brightfield microscopy, which proves the higher sensitivity of the fluorescence assay over that of the brightfield assay.

\section{Detection of small DNA targets}

The in situ hybridized subtelomeric probe for chromosome 1 and the thyroglobulin probes could be detected by either the APase-Fast Red or FITC fluorescence technique, but only the former probe could also be detected as a red-colored absorption signal by brightfield microscopy (Reactions 5 and 6, Table 3). Figures 11 and $1 \mathrm{~m}$ and $1 \mathrm{n}$ and $1 \mathrm{o}$ show the detection of the p1-79 and thyroglobulin probe, respectively, on metaphase spreads after staining with the APase-Fast Red technique and fluorescence microscopy. Both probes were detected with three incubation steps of respectively MABio, BioHAM, and Av/BioAPase (Reactions 5 and 6, Table 3). The same sensitivity could be obtained on interphase nuclei (data not shown).

\section{Quantitation of the fluorescence of the APase-Fast Red reaction product}

Thus far, the results demonstrate that highly repetitive DNA sequences as well as single-copy DNA sequences can be detected with both the APase-Fast Red technique (using fluorescence microscopy) and the FITC fluorescence procedure. To obtain an impression of the fluorescence intensity of the APase-Fast Red ISH signals, we quantitated these signals in T24 cell nuclei, which were stained according to Procedure 6, Table 1. These fluorescence intensities were compared to intensities of the fluorochrome Texas Red, since both the APase-Fast Red reaction product and the 
Table 2. The effect of incubation time of the staining reaction on both the discreteness of localization and fluorescence intensity of APase-Fast Red ISH signals in 24 interphase nuclet and human bymphocyte metaphase preparations $a, b$.

\begin{tabular}{|c|c|c|c|c|c|}
\hline Reaction & $\begin{array}{l}\text { Reaction time } \\
\text { (min) }\end{array}$ & $\begin{array}{c}\text { Fluorescence } \\
\text { intensity of } \\
\text { ISH signals }\end{array}$ & $\begin{array}{l}\text { Background } \\
\text { Tworescence } \\
\text { in the nucle }\end{array}$ & $\begin{array}{c}\text { Discreteness } \\
\text { of } \\
\text { localization }\end{array}$ & $\begin{array}{l}\text { Absorption } \\
\text { signals }\end{array}$ \\
\hline 1 & 5 & + & Low & Grood & \pm \\
\hline 2 & 15 & $+t+$ & Low & Good & + \\
\hline 3 & 30 & $+t+$ & Moderate & $\begin{array}{l}\text { Reasonable (T24) } \\
\text { Poor (metaphase) }\end{array}$ & $+t+$ \\
\hline
\end{tabular}

a The APase-Fast Red reaction was performed at RT, using the stain solution as described in Procedure 6, Table 1.

b The biotinylated centromere probe for chromosome 1 (pUC 1.77) was detected by three cytochemical layers of, respectively, APase-conjugated avidin (AvAPase), biotinylated goat antiavidin, and AvAPase.

c \pm , weakly positive; + , positive; ++ , strongly positive; $+t+$, extremely positive.

Table 3. Comparison of the sensitivity of the APase-Fast Red technique wsing either fluorescence or brightfield microscopy and a FITC fluorescence procedure for the detection of several biotinylated DNA probes in metaphase spreads of normal human lymphocytes ${ }^{a}$.

ISH signal intensity

\begin{tabular}{lccccc} 
Reaction & Biotinylated probe & $\begin{array}{c}\text { Probe concentration } \\
(\mathrm{pg} / \mu)\end{array}$ & $\begin{array}{c}\text { APase-Fast Red } \\
\text { fluorescence }\end{array}$ & $\begin{array}{c}\text { APase-Fast Red } \\
\text { absorption }\end{array}$ & $\begin{array}{c}\text { FITC } \\
\text { fluorescence }\end{array}$ \\
\hline 1 & pUC $1.77^{c}$ & $4 \times 10^{2}$ & +++ & ++ & +++ \\
2 & pUC 1.77 & $4 \times 10^{1}$ & $++1+++$ & + & $++1+++$ \\
3 & pUC 1.77 & 8 & ++ & + & ++ \\
4 & pUC 1.77 & 4 & $+1++$ & + & $+1++$ \\
5 & p1-79d & $1 \times 10^{3}$ & ++ & + & ++ \\
6 & Thyroglobulin & $2 \times 10^{3}$ & + & + & + \\
\hline
\end{tabular}

The APase-Fast red reaction was performed for 15 min at RT with the stain solution as described in Procedure 6, Table 1.

b - negative; \pm , weakly positive; + , positive; ++ , strongly positive; +++ , extremely positive.

c The biotinylated centromere probe for chromosome 1 (pUC 1.77) was detected by using three cytochemical layers of, respectively, APase-conjugated avidin (AvAPase), biotinylated goat antiavidin (BioGAA), and AvAPase (for the APase-Fast Red technique) or FITC-conjugated avidin (AvFITC), BioGAA, and AvFTTC (for the FITC fluorescence technique).

Both the biotinylated subtelomere 1-specific probe p1-79 and the thyroglobulin probes were detected by using three cytochemical layers of, respectively, mouse anti-biotin, biotinylated horse anti-mouse IgG, and an avidin biotinylated APase complex (for the APase-Fast Red technique) or AvFITC, BioGAA, and AvFITC (for the FITC fluorescence technique). 
Texas Red label can be excited by the same laser wavelenght $(568 \mathrm{~nm})$ in confocal scanning laser microscopy. Therefore, the same biotinylated centromere 1-specific probe pUC 1.77 was detected with two layers of AvTXRED. Using the same background correction, the fluorescence intensity of the APase-Fast Red ISH signals was approximately three times as high as that of the Texas Red ISH signals (data not shown).
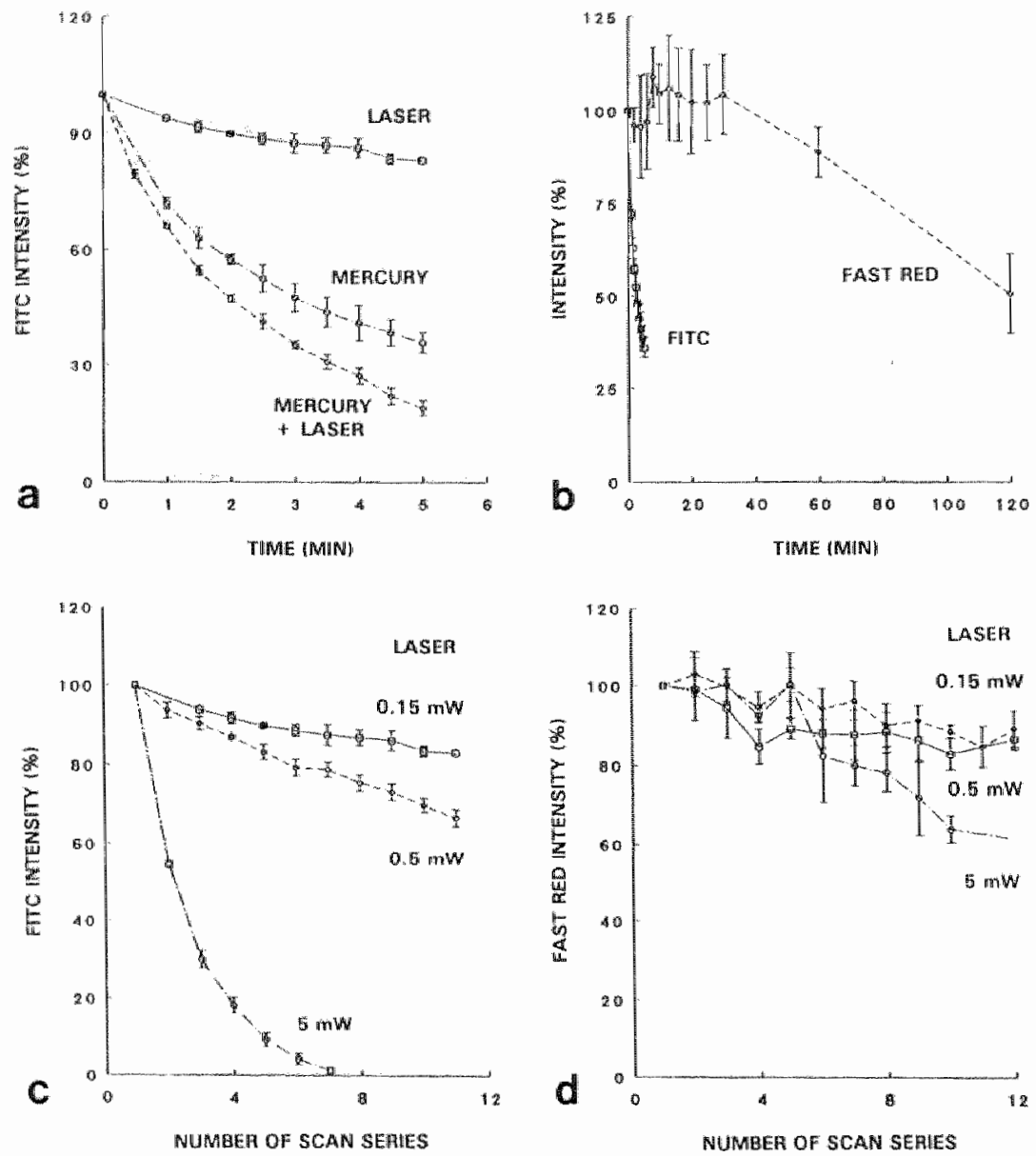

Figure 2. Bleaching properties of APase-Fast Red fluorescence as compared with FITC fluorescence. (a) Decrase of FITC fluorescence intensity after exposure to $0.15 \mathrm{~mW} 488-\mathrm{nm}$ laser light, mercuryarc light (FITC filter set), or a combination of both. (b) Decrease of FITC and APase-Fast Red fluorescence intensity after exposure to blue mercury-arc light (FTC filter set) and green mercuryare light (TXRED filter set), respectively. (c) Decrease of FITC fluorescence intensity after exposure to several scan series of $488-\mathrm{min}$ laser light at $0.15,0.5$, and $5 \mathrm{~mW}$. Each scan series covered 30 scans of $1 \mathrm{sec}$ each. (d) Decrease of APase-Fast Red fluorescence intensity after exposure to several scan series of 568-nm laser light at $0.15,0.5$, and $5 \mathrm{~mW}$. Each scan series covered 30 scans of $1 \mathrm{sec}$ each. 


\section{Bleaching of the fluorescent APase-Fast Red ISH signals}

We examined the bleaching properties of the APase-Fast Red reaction product by determining the effect of illumination with (a) light from the mercury-arc lamp and (b) different intensities of laser light, on the fluorescence intensity of specific FITC and APase-Fast Red ISH signals (Figure 2).

\section{Exposure to mercury-arc light}

Figure 2a shows that the effect of illumination with the mercury-arc lamp (blue light, FITC filter set) on FITC fluorescence intensity has a more profound effect than illumination with $488 \mathrm{~nm}$ laser light of $0.15 \mathrm{~mW}$. Within 5 min of constant illumination with mercury-arc or laser light, the FITC signal intensity was reduced by about $60 \%$ and $15 \%$, respectively. In the same way, the effect of illumination with both the mercury-arc light (TxRED filter set) and $568 \mathrm{~nm}$ laser light of $0.15 \mathrm{~mW}$ on the APase-Fast Red ISH signal intensities was assessed (Figure 2b). It appeared, that within 5 min of exposure to mercury-arc light no bleaching of the APase-Fast Red signal was observed, and that only $10 \%$ bleaching was measured after 5 -min exposure to the laser light (data not shown). Therefore, the APase-Fast Red signals were illuminated up to $120 \mathrm{~min}$ with mercury-arc light to determine, if reduction of the fluorescence intensity could be observed. Figure $2 b$ illustrates, that approximately $50 \%$ of the ISH signal intensity is left after 120 min of illumination, which makes the fluorescent APase-Fast Red label far less sensitive to bleaching by mercury-arc light than the FITC label.

\section{Exposure to laser light}

To investigate the effect of scanning with laser light intensities on the intensity and bleaching of the FITC and APase-Fast Red signals, the preparations were exposed to laser light of $0.15,0.5$, and $5 \mathrm{~mW}$ in 12 series of 30 scans, 1 sec each. The results are presented in Figures $2 \mathrm{c}$ and $2 \mathrm{~d}$. It is obvious from Figure $2 \mathrm{c}$, that the intensity of FITC signals was reduced to approximately $85 \%$ after illumination with $0.15 \mathrm{~mW}$ laser light, to $70 \%$ after 12 scan series of $0.5 \mathrm{~mW}$ laser light, and was no longer detectable after seven scan series of $5 \mathrm{~mW}$ laser light. The APase-Fast Red fluorescence intensity, on the contrary, was still more than $60 \%$ of the original signal intensity after the 12 scan series with $5 \mathrm{~mW}$ laser light. Scanning with 0.15 or 0.5 $\mathrm{mW}$ laser light led in both cases to similar results and a reduction of approximately $10 \%$ after 12 scan series.

\section{DISCUSSION}

In this report, we describe the application of the APase-Fast Red technique to fluorescence ISH. In both interphase and metaphase preparations, the parameters for an accurate localization and high fluorescence intensity of the APase-Fast Red ISH signals were determined. Cytochemical detection of the centromere 1-specific DNA probe was performed by a procedure with three subsequent layers of AvAPase, 
BioGAA, and AvAPase, followed by the APase-Fast Red reaction. A one layer (AvAPase) or two layer (avidin and BioAPase) detection system resulted in only weak and more diffuse fluorescent APase-Fast Red ISH signals (see also Speel et al., 1992). For the detection of small DNA target sequences, using, e.g., the subtelomere 1-specific probe p1-79 or the thyroglobulin probes, we prefer to use the MABioBioHAM-Av/BioAPase detection procedure, since this method proved to be even more efficient than those described above.

\section{Optimal conditions for the APase-Fast Red detection system}

A distinct localization as well as strong fluorescence intensity of the APase-Fast Red ISH signals was obtained by reducing the concentrations of naphthol-ASMXphosphate and Fast Red TR in the final staining buffer. Addition of PVA improved the discreteness of localization of the ISH signals obtained, most probably by reducing diffusion of the reaction product. Although we normally used $4 \%$ PVA in the staining buffer, concentrations between $4 \%$ and $18 \%$ PVA can be utilized for improvement of the discreteness of localization or for other reasons (Van Noorden and Vogels, 1989; Kiyama and Emson, 1991).

The reaction time of the final staining step was of importance to obtain acceptable ISH results and, thus, an acceptable resolution. In both interphase and metaphase preparations, optimal fluorescence results were obtained with a reaction time of 15 min (Table 2). However, since the size of the target to which the probe hybridizes is also of importance, individual cases normally need further optimization of the discreteness of localization of APase-Fast Red ISH signals. This can be obtained after fine-tuning of the reaction time.

Unlike the fluorescence ISH results, the optimal absorption results were obtained only after 30 min of staining time. A similar finding was also reported by Ziomek et al. (1990). It seems, that staining reactions longer than 15 min cause the fluorescence intensity of the ISH signals to reach a level, at which self-absorption of emitted fluorescence light by the reaction product prevents a further increase of the fluorescence intensity (Tanke et al., 1982).

\section{Sensitivity of the APase-Fast Red detection system}

With respect to the sensitivity of the APase-Fast Red technique, one must realize that many conditions influence the formation of the final reaction product at the enzymatic site. The precipitate is the result of a complex system of chemical reactions and physical processes, in which the undesirable oufflow of intermediates and still unprecipitated final reaction products can lead to inaccurate localization of that enzymatic site (Van Duijn, 1991). Moreover, parameters such as pH, buffer composition, ionic strength, and temperature have been shown to strongly influence the efficiency of these enzymatic reactions (Lojda, 1976; Raap, 1986; Van Duijn and Van Noorden, 1989; Van Duijn, 1991).

Our modified APase-Fast Red procedure was shown to be a sensitive method for the detection of DNA target sequences up to the level of single-copy genes. Therefore, the sensitivity of this technique is comparable to the sensitivity of other fluorescence 
ISH procedures, e.g., the FITC fluorescence technique as described in Table 3. Furthermore, fluorescence detection of the APase-Fast Red reaction product proved to be more sensitive than brightfield detection of the precipitate.

\section{Diffusion of the APase-Fast Red precipitate}

Metaphase spreads incubated with the centromere 1-specific DNA probe show, after a 30-min APase-Fast Red reaction, a diffuse, total staining of chromosome 1. This observation can be explained by presuming, that diffusion of reaction product occurs from the centromeric site along the entire chromosome within the chromosome matrix. However, close examination of several FITC-labeled ISH preparations, reacted with the centromere probe, revealed that in some cases very small spots were distributed over the entire chromosome, next to centromeric signals. These small "aspecific" interaction sites can be observed after ISH with probe lenghts $>500$ bp in hybridization mixtures with dextran sulphate. For this reason, it is conceivable that the observed diffuse staining of the complete chromosome 1 is caused by the high sensitivity of the APase-Fast Red technique, which in combination with the diffusion phenomenon leads to a complete chromosome staining. To prevent this "aspecific" staining phenomenon as much as possible, we prefer a staining period of $15 \mathrm{~min}$ in a PVA-containing buffer.

For detection of repeated DNA (centromere and telomere) sequences in metaphase spreads, ISH procedures without dextran sulphate can lead to an even more discrete localization of the APase-Fast Red ISH signals. This results in only slightly less intense ISH signals.

Quantitation of the fluorescence intensities of ISH signals using the APase-Fast Red precipitate and TxRED as the fluorescent labels revealed, that APase-Fast Red ISH signal intensities were comparable to or even stronger than TxRED signal intensities. Therefore, the APase-Fast Red technique has the potential to serve as a sensitive detection method for ISH.

\section{Applications of slowly quenching fluorophores}

Application of the APase-Fast Red technique in double-target ISH can be of importance, since only one filter on the microscope is necessary to observe the redorange APase-Fast Red fluoresence in combination with the green FITC fluorescence. The major advantage of this technique is the fact, that the bleaching characteristics of the fluorescent precipitate are such that, after exposure to either mercury-arc light or different intensities of laser light, bleaching occurs at a very slow rate as compared with FITC. Therefore, the bleaching characteristics of the fluorescent APase-Fast Red precipitate are of significant advantage for ISH studies, in which fading is a serious problem, especially for routine detection of small nucleic acid target sequences and for ISH studies using confocal scanning laser microscopy. Further exploration will reveal, if this fluorescence detection method is also useful for immunocytochemistry. 


\section{Acknowledgements}

We are gratefull to Prof Dr P van Duijn (Department of Cytochemistry and Cytometry, University of Leiden, The Netherlands) and Dr CJF wan Noorden (Laboratory of Cell Biology and Histology, University of Amsterdam, The Netherlands) for their helpful advice and for reading and correcting the manuscript (PWD). This work wass supported by the Dutch Foundation for Medical and Health Research (Medigon), grant no. 900-534-073 and 900-534-102, and presented in part at the XV ISAC meeting, August 25-30, 1991, in Bergen, Norway (Speell et al., 1991).

\section{REFERENCES}

Arndt-Jovin DJ, Robert-Nicoud M, Baurschmidt P, Jovin TM (1985) Immunofluorescence localization of Z-DNA in chromosomes: quantitation by scanning microphotometry and computer assisted image analysis. J Cell Bioll 101:1422-1433

Bauman JGJ, Wiegant $J$, Borst P, Van Duijn P (1980) A new method for fluorescence microscopical localization of specific DNA sequences by in situ hybridization of fluorochrome labeled RNA. Exp Cell Res $128: 485-490$

Beverloo HB, Van Schadewijk A, Van Gelderen-Boele S, Tanke HI (1990) Inorganic phosphors as new luminescent labels for immunocytochemistry and time-resolved microscopy. Cytometry 11:784792

Böck G, Hilchenbach M, Schanenstein K, Wick G (1985) Photometric analysis of antifading reagents for immunofluorescence with laser and conventional illumination sources. J Histochem Cytochem 33:699-705

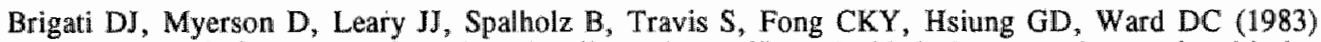
Detection of viral genomes in cultured cells and paraffin-embedded tissue sections using biotinlabeled hybridization probes. Virology 126:32-50

Bronstein I, Voyta JC (1989) Chemiluminescent detection of Herpes simplex virus I DNA in blot and in-situ hybridization assays. Clin Chem 35:1856-1857

Bubentk J, Baresová V, Viklicky V, Jakoubkovă I, Sainerowa H, Donner I' (1973) Established cell line of urinary bladder carcinoma (T24) containing tumour-specific antigen. Int J Cancer 11:765-773

Buroker $\mathbf{N}_{*}$ Bestwick $\mathbb{R}_{\text {" }}$ Haight $\mathrm{G}$, Magenis $\mathbb{R E}$, Litt $\mathrm{M}$ (1987) A hypervariable repeated sequence on human chromosome 1p36. Hum Genet 77:175-181

Burstone MS (1960) Postcoupling, noncoupling and fuorescence techniques for the demonstration of alkaline phosphatase. J Natl Cancer Inst 24:11.99-1217

Cooke HI, Hindley J (1979) Cloning of human satellite III DNA: different components are on different chromosomes. Nucleic Acids Res 6:3177-3197

Dolbeare $F$, Vanderlaan M, Phares $W$ (1980) Alkaline phosphatase and an acid arylamidase as marker enzymes for normal and transformed WI-38 cells. J Histochem Cytochem 28:419-426

Emmerich P, Loos $\mathbb{P}$, Jauch A, Hopman AHN, Wiegant J, Higgins MJ, White BN, Van der Ploeg $M$, Cremer $C$, Cremer $T$ (1989) Double in situ hybridization in combination with digital image analysis: a new approach to study interphase chromosome topography. Exp Cell Res 181:126-140 
Gall JG, Pardue ML (1969) Molecular hybridization of radioactive DNA to the DNA of cytological preparations. Proc Natl Acad Sci USA 64:600-604

Garson JA, Van den Berghe JA, Kemshead JT (1987) Novel non-isotopic in situ hybridization technique detects small $(1 \mathrm{~kb})$ unique sequences in routinely $\mathrm{G}$-banded human chromosomes: fine mapping of N-myc and $\beta$-NGF genes. Nucleic Acids Res 15:4761-4770

Hopman AHN, Ramaekers FCS, Raap AK, Beck JLM, Devilee P, Van der Ploeg M, Vooijs GP (1988) In situ hybridization as a tool to study numerical chromosome aberrations in solid bladder tumors. Histochemistry $89: 307-316$

John H, Birnstiel M, Jones K (1969) RNA.DNA hybrids at the cytological level. Nature 223:582-587

Johnson GD, Davidson RS, McNamee KC, Russell G, Goodwin D, Halborrow EL (1982) Fading of immunofluorescence during microscopy: a study of its phenomenon and its remedy. I Immunol Methods 55:231-242

Kiyama H, Emson PC (1991) An in situ hybridization histochemistry method for the use of alkaline phosphatase-labeled oligonucleotide probes in small intestine. J Histochem Cytochem 39:1377-1384

Landegent JE, Jansen in de Wal N, Van Ommen G-JB, Baas F, De Vijlder JJM, Van Duijn P, Van der Ploeg M (1985) Chromosomal localization of a unique gene by non-autoradiographic in situ hybridization. Nature 317:175-177

Lawrence JB, Villnave CA, Singer RH (1988) Sensitive, high-resolution chromatin and chromosome mapping in situ: presence and orientation of two closely integrated copies of EBV in a lymphoma line. Cell $52: 51-61$

Lojda $Z_{*}$ Grossrau R, Schiebler TH (1976) Enzym-histochemische methoden. Berlin Heidelberg New York, Springer-Verlag

Mason DY (1985) Immunocytochemical labeling of monoclonal antibodies by the APAAP immunoalkaline phosphatase technique. In Bullock GR, Petrusz $P$ (eds): Techniques in immunocytochemistry, Vol 3. London, Academic Press, pp 36

Matsuno K, Ezaki T, Kotani M (1989) Splenic outer periarterial lymphoid sheath (PALS): an immunoproliferative microenvironment constituted by antigen-laden marginal metallophils and ED2positive macrophages in the rat. Cell Tissue Res 257:459-470

Morrison L, Legator M (1991) Multi-color in sitw hybridization using direct-labeled fluorescent probes. Cytometry (suppl) 5:131

Murdoch A, Jenkinson EJ, Johnson GD, Owen JJT (1990) Alkaline phosphatase-fast red, a new fluorescent label. Application in double labelling for cell surface antigen and cell cycle analysis. $J$ Immunol Methods 132:45-49

Nederlof PM, Robinson D, Abuknesha R, Wiegant J, Hopman AHN, Tanke HJ, Raap AK (1989) Three-color fluorescence in situ hybridization for the simultaneous detection of multiple nucleic acid sequences. Cytometry $10 \div 20-27$

Raap AK (1986) Localization properties of fluorescence cytochemical enzyme procedures. Histochemistry 84:317-321

Raap AK, Hopman AHN, Van der Ploeg M (1989) Hapten labeling of nucleic acid probes for DNA in situ hybridization. In Bullock GR, Petrusz P (eds): Techniques in immunocytochemistry, Vol 4. Cambridge, University Press, pp 167-197 
Robert-Nicoud $M$, Amdt-Jovin Dr, Schormann T, Jovin TM (1989) 3-D imaging of cells and tissues using confocal laser scanning microscopy and digital processing. Eur J Cell Biol 48 (suppl 25):49-52

Rudkin GT, Stollar BD (1977) High resolution detection of DNA-RMA hybrids in situ by indirect immunofluorescence. Nature 265:472-473

Speal EIM, Schutte B, Ramaekers FCS, Hopman AHN (1991) Application of the alkaline phosphatase/fast red immunodetection system for in situ hybridization fluorescence confocal microscopy. Cytometry (suppl) $5: 133$

Speel EIM, Schutte B, Ramaekers FCS, Hopman AHN (1992) The effect of avidin-biotin interactions in detection systems for in situ hybridization. I Histochen Cytochem 40:135-141

Tanke HJ, Van Oostveldt P, Van Duijn P (1982) A parameter for the distribution of fluorophores in cells derived from measurements of inner filter effect and reabsorption phenomenon. Cytometry $2: 359-369$

Trask BJ (1991) Fluorescence in situ hybridization: applications in cytogenetics and gene mapping. Trends Genet 7:149-154

Van der Ploeg M, Van Duijn P (1968) Cytophotometric determination of alkaline phosphatase activity of indiwidual neutrophilic leucocytes with a biochemically calibrated model system. I Histochem Cytochem 16:693-706

Van Duijn P, Van Noorden CJF (1989) Plateau absorbance measurements: an alternative approach to enzyme activity determination illustrated by the example of alkaline phosphatase. Histochem I $21: 619-624$

Van Duijn P (1991) Model systems. Principles and practice of the use of matrix-immobillized enzymes for the study of the fundamental aspects of cytochemical enzyme methods. In Stoward PJ, Pearse AGE (eds): Histochemistry, theoretical and applied, Vol 3, 4th ed. Edinburgh, Churchil] Livingstone, pp 433 472

Van Noorden CJF, Vogels IMC (1989) Polyvinylalcohol and other tissue protectants in enzyme histochemistry: a consumer"s guide. Histochem 『21:373-379

Van Ommen G-JB, Arnberg AC, Baas F, Brocas H, Sterk A, Tegelaers HH, Vassart $G_{,}$De Vijlder JJM (1983) The human thyroglobulin gene contains two $15-17 \mathrm{~kb}$ introns near its 3 -end. Nucleilc Acids Res 11:2273-2285

Viegas Pequignot E, Dutrillaux B, Magdelenat H, Coppey-Moisan M (1989) Mapping of single-copy DNA sequences on human chromosomes by in situ hybridization with biotinylated probes: entancement of detection sensitivity by intensified-fluorescence digital-imaging microscopy. Proc Natl Acad Sci USA 86:582-586

Waye JS, England SB, Willard HF (1987) Genomic organization of alpha satellite DNA on human chromosome 7: evidence for two distinct alphoid domains on a single chromosome. Mol Cell Biol $7 \cdot 349-356$

Wiegant J, Ried T, Nederlof PM, Van der Ploeg M, Tanke HJ, Raap AK (1991) In situ hybridization with fluoresceinated DNA. Nucleic Acids Res 19:3237-3241

Ziomek CA, Lepire ML, Torres I (1990) A highly fluorescent simultaneous azo dye technique for demonstration of nonspecific alkaline phosphatase activity. J Histochem Cytochem 38:437-442 


\title{
CHAPTER 4
}

\section{MULTICOLOR PREPARATIONS FOR IN SITU HYBRIDIZATION USING PRECIPITATING ENZYME CYTOCHEMISTRY IN COMBINATION WITH REFLECTION CONTRAST MICROSCOPY}

\author{
Ernst JM Speel, Miriam Kamps, Jan Bonnet, Frans CS Ramaekers, \\ Anton HN Hopman
}

Histochemistry 100, 357-366, 1993

\begin{abstract}
We have further developed a method for the detection of different enzyme cytochemical reaction products by means of reflection contrast microscopy (RCM). By embedding these enzyme precipitates in a protein matrix, we were able to prevent the reaction products from dissolving in immersion oil, which is required for RCM analysis. The applicability of the RCM procedure is, therefore, extended to a range of cytochemical enzyme precipitation methods, which normally result in oil soluble reaction products. To test their usefulness, these enzyme precipitates have been used in single- as well as double-label in situ hybridization procedures to visualize a number of DNA target sequences by several different reflection colors, i.e., white, yellow, and red. Three repetitive DNA probes for the (sub)centromeric regions of chromosomes 1,7 , and 17 , as well as a repetitive DNA probe for the telomeric region of chromosome 1, and two cosmid DNA probes ( $40 \mathrm{~kb}$ each) for both arms of chromosome 11 could be detected with high efficiency in both interphase and metaphase preparations. Moreover, the enzyme precipitates were shown to be stable upon exposure to excitation light or upon storage. It may be concluded, that these findings render RCM a sensitive method for the visualization of multiple targets in biological specimens.
\end{abstract}




\section{INTRODUCTION}

Non-radioactive in situ hybridization (ISH) has become an important tool for the analysis of the number, size, and localization of specific DNA sequences in mammalian cells (Hopman et al., 1988; Lichter et al., 1991; Trask, 1991). DNA target sequences ranging from complete chromosomes to fragments of $1-6 \mathrm{~kb}$ can be detected with high efficiency in tissue and cell preparations (Landegent et al., 1985b; Garson et al., 1987; Lawrence et al., 1988; Lichter et al., 1988; Viegas-Pequignot et al., 1989; Trask, 1991). With these procedures modified DNA probes, interacting specifically with their target, can be visualized either directly (Wiegant et al., 1991), or indirectly, after incubation with cytochemical detection layers, e.g., avidin or antibody conjugates. These conjugates can carry various reporter molecules, such as fluorochromes (Nederlof et al., 1989), lanthanide chelates (Seveus et al., 1992), colloidal gold particles (Narayanswami and Hamkalo, 1991), or enzymes (Emmerich et al., 1989), for use in different types of microscopical techniques.

At present, fluorescent markers are widely utilized because of the high sensitivity of fluorescence ISH, combined with the fact that different fluorochromes are available (Nederlof et al., 1989). Therefore, it is possible to detect multiple DNA target sequences in different colors using only one preparation (Dauwerse et al., 1992; Ried et al., 1992). We have recently described the application of the alkaline phosphatase (APase)-Fast Red reaction to ISH. This method allowed small DNA targets to be detected with high efficiency, whereas the resulting precipitate proved to be a virtually permanent fluorochrome (Speel et al., 1992b).

Reflection contrast microscopy (RCM) is another sensitive technique that allows single-copy DNA sequences to be accurately detected in metaphase preparations (Landegent et al., 1985b; Ambros et al., 1986). In this procedure, the DNA target sequences can be visualized by means of the horseradish peroxidase-diaminobenzidine (PO-DAB) reaction, utilizing the capacity of the PO-DAB reaction product to reflect white incident light. RCM was originally introduced in cell biology for cell adhesion studies (Ploem, 1975), and has found further applications in the evaluation of both immunoperoxidase- and immunogold-silver stained cell preparations and thin tissue sections (Landegent et al., 1985a; Hoefsmit et al., 1986; Cornelese-ten Velde et al., 1988, 1989; Cornelese-ten Velde and Prins, 1990). In comparison with brightfield microscopy and fluorescence microscopy, the advantage of RCM is the high resolution that can be obtained in combination with the use of a specific and nonfading label. Furthermore, no counterstaining is needed, since unstained cells or tissue sections can also be visualized by means of RCM.

In order to extend the applicability of RCM to the detection of multiple targets in biological specimens, more enzyme cytochemical methods should be available, which can be combined in one preparation for RCM analysis. The application of oil (with a refractive index equal to glass) between the objective and the glass slide is necessary to prevent reflection at the glass-air interphase (Cornelese-ten Velde et al., 1988). However, this hampers the detection of several enzyme reaction products by RCM, because of their solubility in organic solvents. In this report, we present a procedure 
to prevent different enzyme reaction products from being dissolved in oil by embedding these enzyme precipitates in a protein matrix. As a result, the reflection capacity and color of nine different enzyme reaction products, precipitated in a singletarget ISH experiment, could be examined with RCM. Moreover, these reaction products could now be utilized in double-target ISH.

\section{MATERIALS AND METHODS}

\section{Cell processing}

Five microlitres $\left(3 \times 10^{6}\right.$ cells $\left./ \mathrm{ml}\right)$ of a $70 \%$ ethanol suspension of the human transitional cell carcinoma line T24 [DNA index 1.6; trisomic for the centromeres of chromosomes 1 and 7; (Bubeník et al., 1973)] was processed for ISH as described earlier (Hopman et al., 1988; Speel et al., 1992a). In brief, cells were spotted onto poly-L-lysine-coated glass slides, air-dried, and heated for $1 \mathrm{hr}$ at $80^{\circ} \mathrm{C}$ on a heating plate. Digestion with pepsin from porcine stomach mucosa (2500-3500 U/mg protein; Sigma, St Louis, MO, USA) at a concentration of $100 \mu \mathrm{g} / \mathrm{ml}$ in $0.01 \mathrm{M} \mathrm{HCl}$ for 20 min at $37^{\circ} \mathrm{C}$ was followed by five washes in demineralized water (Milli Q), five subsequent washes in phosphate-buffered saline (PBS: $0.15 \mathrm{M} \mathrm{NaCl}, 10 \mathrm{mM} \mathrm{Na}$ phosphate, $\mathrm{pH} \mathrm{7.2),} \mathrm{and} \mathrm{fixation} \mathrm{in} 1 \%$ paraformaldehyde in PBS for 20 min at $4^{\circ} \mathrm{C}$. After five washes in PBS and five washes in Milli Q, the slides were dehydrated in an ascending series of ethanol $(70 \%, 96 \%, 100 \%)$.

\section{Preparation of metaphase spreads}

Metaphase chromosome spreads were obtained from phytohemagglutinin-stimulated human peripheral blood lymphocytes as previously described (Speel et al., 1992b). Briefly, human lymphocytes were grown for 3 days in $1 \mathrm{x}$ chromosome medium (Boehringer, Mannheim, Germany) at $37^{\circ} \mathrm{C}$. Two hours before harvest, colcemid (Gibco BRL, Breda, The Netherlands) was added to a final concentration of 0.2 $\mu \mathrm{g} / \mathrm{ml}$. The cells were collected by centrifugation, suspended in swelling buffer containing $50 \mathrm{mM} \mathrm{KCl}, 5 \mathrm{mM} \mathrm{N}$-[2-hydroxyethyl]-piperazine- $\mathrm{N}^{\prime}$-[2-ethanesulfonic acid] (Hepes), $10 \mathrm{mM} \mathrm{MgSO}_{4}$, and $3 \mathrm{mM}$ dithiothreitol, pH 8.0 , at $37^{\circ} \mathrm{C}$ for $20 \mathrm{~min}$, and washed four times in freshly made fixative (methanol/acetic acid 3:1 v/v). These cell suspensions were stored at $-20^{\circ} \mathrm{C}$ until use. Cells were dropped onto ethanol/ether $(1: 1 \mathrm{v} / \mathrm{v})$ cleaned glass slides and, after air-drying, treated with $100 \mu \mathrm{g} / \mathrm{ml}$ RNase A (Boehringer) in $2 x S S C(0.3 \mathrm{M} \mathrm{NaCl}, 30 \mathrm{mM} \mathrm{Na-} \mathrm{citrate),} \mathrm{pH} 7.0$, under a coverslip for $1 \mathrm{hr}$ at $37^{\circ} \mathrm{C}$. Cells were given three subsequent washes with $2 \times S S C, p H 7.0$, for $5 \mathrm{~min}$ at $37^{\circ} \mathrm{C}$. Digestion with pepsin was then performed at a concentration of 100 $\mu \mathrm{g} / \mathrm{ml}$ in $0.01 \mathrm{M} \mathrm{HCl}$ under a coverslip for $10 \mathrm{~min}$ at $37^{\circ} \mathrm{C}$, followed by five dip washes in Milli $Q$ and two washes in PBS and PBS containing $50 \mathrm{mM} \mathrm{MgCl}$, respectively, for $5 \mathrm{~min}$ at room temperature (RT). The preparations were post-fixed with $1 \%$ formaldehyde in PBS/50 mM MgCl 2 for 10 min at $\mathrm{RT}$, washed twice in PBS, dehydrated in ethanol, and kept at until use. 


\section{DNA probes and labeling procedure}

The probes for the (peri)centromeric regions of the human chromosomes $\mathbb{1}$ (pUC 1.77), 7 (p7t1), and 17 (p17H8) have been described by Cooke and Hindley (1979), Waye et al. (1987), and Waye and Willard (1986), respectively. The human 1pspecific subtelomeric probe p1-79 was described by Buroker et al. (1987). The cosmid clones cCII11-310 and cCII11-314, specific for $40 \mathrm{~kb}$ of DNA target on chromosome $11 \mathrm{p} 15$ and $11 \mathrm{q} 23$, respectively, were described by Tokino et al. (1991). All the DNA probes were biotinylated with biotin-11-dUTP (Enzo Diagnostics, New York, NY, USA) in a nick translation reaction as described by Brigati et al. (1983), with the exception of the $\mathrm{p} 7 \mathrm{t} 1 \mathrm{and} \mathrm{p} 17 \mathrm{H} 8$ probes. The $\mathrm{p} 7 \mathrm{t} 1$ and $\mathrm{p} 17 \mathrm{H} 8$ probes were labeled with digoxigenin-11-dUTP (Boehringer) in a nick- translation reaction, for use in a double-target ISH procedure in combination with a biotinylated probe.

\section{In situ hybridization}

All the DNA probes described above, except for the cosmid probes, were hybridized in single- and double-target ISH in a hybridization buffer containing $60 \%$ formamide, $2 \times S S C$, pH $5.0,10 \%$ dextran sulphate, $0.2 \mu \mathrm{g} / \mu$ l herring sperm DNA as carrier DNA, and $0.2 \mu \mathrm{g} / \mu \mathrm{l}$ yeast tRNA as carrier RNA. In the single-target ISH procedure,

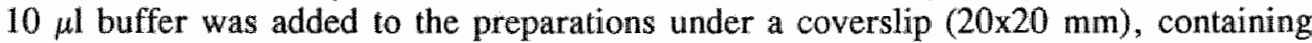
$4 \mathrm{ng}$ biotinylated pUC 1.77 DNA or $10 \mathrm{ng}$ biotinylated pl-79 DNA. For doubletarget ISH, the buffer contained $4 \mathrm{ng}$ biotinylated pUC 1.77 DNA together with $10 \mathrm{ng}$ digoxigenin-labeled $\mathrm{p} 7 \mathrm{tl}$ or p17H8 DNA. Denaturation was performed on the bottom of a metal box in a water bath at $70^{\circ} \mathrm{C}$ for $4 \mathrm{~min}$ and hybridization was performed overnight at $37^{\circ} \mathrm{C}$. The slides were washed $2 \times 10$ min at $42^{\circ} \mathrm{C}$ with $60 \%$ formamide, $2 \times$ SSC, pH 5.0 , containing $0.05 \%$ Tween 20 , followed by two 5 -min washes with $2 \times S S C, p H 7.0$, at $42^{\circ} \mathrm{C}$, and a 5 -min wash with $4 \times S S C, p H 7.0$, containing $0.05 \%$ Tween 20 (Buffer A) at RT.

The two biotinylated cosmid probes were pre-annealed at a concentration of $4 \mathrm{ng} / \mu \mathrm{l}$ to $2 \mu \mathrm{g} / \mu \mathrm{l}$ fragmented $(50-500 \mathrm{bp})$ total human lymphocyte DNA in $50 \%$ formamide, $2 \times S S C$, pH $5.0,10 \%$ dextran sulphate, $0.2 \mu \mathrm{g} / \mu \mathrm{l}$ herring sperm DNA, and $0.2 \mu \mathrm{g} / \mu \mathrm{l}$ yeast tRNA. After denaturation for $5 \mathrm{~min}$ at $80^{\circ} \mathrm{C}, 10 \mu \mathrm{l}$ was added to a pre-heated slide (in situ DNA denaturation, see below) under a coverslip and sealed with rubber cement. After hybridization overnight at $37^{\circ} \mathrm{C}$ and removal of the rubber cement, the slides were washed $2 \times 10 \mathrm{~min}$ at $42^{\circ} \mathrm{C}$ with $50 \%$ formamide, $2 \times S S C$, pH 5.0 , containing $0.05 \%$ Tween 20 , followed by two 5 -min washes with $0.1 \times S S C, p H 7.0$, at $60^{\circ} \mathrm{C}$ and a 5 min wash with Buffer A at RT.

In situ DNA was denaturated by adding $100 \mu \mathrm{l}$ of $70 \%$ formamide, $2 \times \mathrm{SSC}, \mathrm{pH} 5.0$, to a slide under a coverslip $(24 \times 50 \mathrm{~mm})$, after which it was placed on the bottom of a metal box in a waterbath at $80^{\circ} \mathrm{C}$ for $3 \mathrm{~min}$. After removal of the coverslip, the slide was brought to $70 \%$ ethanol at $-20^{\circ} \mathrm{C}$ for $5 \mathrm{~min}$, followed by dehydration at RT ( 5 min $96 \%$ ethanol and $5 \min 100 \%$ ethanol) and air-drying. 


\section{Cytochemical detection procedures}

To reduce background staining, the slides were pre-incubated with $4 \mathrm{xSSC}, \mathrm{pH} 7.0$, containing $5 \%$ non-fat dry milk (Buffer B) for $10 \mathrm{~min}$ at $37^{\circ} \mathrm{C}$, followed by dipping in Buffer $\mathrm{A}$.

For the detection of the biotinylated pUC 1.77 probe by $P O$ cytochemistry (see below), the slides were incubated with a 1:50 dilution of PO-conjugated avidin (AvPO; Dako, Glostrup, Denmark). For the detection of the biotinylated pUC 1.77, p1-79, and cosmid probes by alkaline phosphatase (APase) cytochemistry (see below), the slides were subsequently incubated with layers of mouse anti-biotin (MABio, 1:100; Dako), biotinylated horse anti-mouse IgG (BioHAM, 1:200; Vector, Brunschwig Chemie, Amsterdam, The Netherlands), and a streptavidin biotinylated APase complex (StrAv/BioAPase; Boehringer), according to the manufacturer's recommendations. Furthermore, a StrAviGen Supersensitive Multilink immunodetection system (Biogenex, San Ramon, CA, USA) was used for APase detection, according to the manufacturer's instructions. For the detection of the biotinylated pUC 1.77 probe by glucose oxidase (GO) cytochemistry (see below), the slides were incubated with subsequent layers of MABio, BioHAM, and an avidin biotinylated GO complex (Av/BioGO), the latter being used according to the manufacturer"s instructions (Vector).

After double-target ISH, first the biotinylated probe was detected as described above (MABio, BioHAM, StrAv/BioAPase), followed by incubations with polyclonal rabbit anti-digoxin (RADig, 1:10; Sigma) and PO-conjugated swine anti-rabbit IgG (SWARPO, 1:40; Dako). Both the APase and PO activities were demonstrated subsequently by the APase-Fast Red reaction and the PO-DAB reaction (see below). For all of the detection procedures, the AvPO conjugates were diluted in Buffer B, the antibody conjugates were diluted in PBS containing 0.05\% Tween 20 (Buffer C) and $2 \%$ normal goat serum, and the avidin biotinylated enzyme complexes (ABC) were formed and used in $4 \times \mathrm{SSC}, \mathrm{pH} 7.0$. After each incubation step of 30 min at $37^{\circ} \mathrm{C}$, the slides were rinsed twice in the appropriate dilution buffer (without serum) for 5 min at RT.

Controls included (1) the use of hybridization buffer without a DNA probe, (2) substitution of one of the detection layers with buffer, and (3) omission of one of the constituents in the enzyme reaction mixture.

\section{Alkaline phosphatase cytochemistry}

\section{APase-Fast Red reaction}

APase detection was performed as described previously (Speel et al., 1992b). Briefly, $4 \mathrm{ml}$ of $0.2 \mathrm{M}$ Tris- $\mathrm{HCl}$ buffer, $\mathrm{pH} 8.5$, with $5 \%$ polyvinyl alcohol (PVA, Mw 40000; Sigma), $1 \mathrm{mg}$ naphthol-ASMX-phosphate (Sigma) in $250 \mu \mathrm{l}$ buffer without PVA, and $5 \mathrm{mg}$ Fast Red TR salt (Sigma) in $750 \mu \mathrm{l}$ buffer without PVA, were gently mixed and used immediately. The slides were incubated with $100 \mu$ l of this solution under a coverslip for $5 \mathrm{~min}$ at RT, then washed $3 \times 5$ min with PBS and 5 min with Milli Q. For brightfield as well as fluorescence microscopy, the cells were 
counterstained with hematoxylin, washed with Milli $Q$, air-dried, and mounted in PBS/glycerol $(1: 9 \mathrm{v} / \mathrm{v})$ containing $2.3 \%$ of the anti-bleaching reagent 1,4-diazobicyclo-(2,2,2)-octane (DABCO; Sigma), and $0.5 \mu \mathrm{g} / \mathrm{ml}$ of the nuclear DNA stain 4',6-diamino-2-phenylindole (DAPI; Sigma). For RCM, the cells were not counterstained, air-dried, and stored at RT until use. APase detection was also performed according to the instructions of the StrAviGen Supersensitive Multilink immunodetection system (Biogenex).

\section{APase-NBT/BCIP reaction}

APase detection was performed as described by McGadey (1970). Both $1.8 \mathrm{mg} 5-$ bromo-4-chloro-3-indolyl-phosphate (BCIP; Boehringer) in $100 \mu \mathrm{l} \mathrm{N}, \mathrm{N}$ dimethylformamide, and $3.3 \mathrm{mg}$ nitro blue tetrazolium salt (NBT; Boehringer) in 660 $\mu \mathrm{l}$ Milli $\mathrm{Q}$, were added subsequently to $9.34 \mathrm{ml} 0.2 \mathrm{M}$ Tris- $\mathrm{HCl}, \mathrm{pH} 8.5$, containing $10 \mathrm{mM} \mathrm{MgCl} 2$. The cells were incubated with this solution for $15-30 \mathrm{~min}$ at $37^{\circ} \mathrm{C}$ (100 $\mu \mathrm{l} / \mathrm{slide}$ ), followed by two 5 -min washes with PBS and dehydration. For brightfield microscopy, the cells were air-dried, counterstained with ethylgreen, dehydrated, and mounted in PBS/glycerol $(1: 9 \mathrm{v} / \mathrm{v})$. For RCM, the cells were not counterstained, air-dried, and stored at RT until use.

\section{APase-NBT/BCIP/INT reaction}

APase detection was performed according to the manufacturer's instructions using the APase NBT/BCIP/INT substrate (code no. K 599, Dako).

\section{APase-New Fuchsin reaction}

APase detection was performed according to the manufacturer's instructions using the New Fuchsin substrate system (code no. K 698, Dako).

\section{Horseradish peroxidase cytochemistry}

\section{$P O-A E C$ reaction}

PO detection with $\mathrm{H}_{2} \mathrm{O}_{2}$ and 3,3-amino-9-ethyl carbazole (AEC; Sigma) was performed as described by Graham et al. (1965). In brief, $2.5 \mathrm{ml}$ AEC stock solution (250 mg/25 ml N,N-dimethylformamide) was added to $47.5 \mathrm{ml} 50 \mathrm{mM}$ NaAc buffer, pH 4.9 , followed by filtering. Twenty microlitres $30 \% \mathrm{H}_{2} \mathrm{O}_{2}$ were added to the AEC solution just before use. The preparations were incubated for $10 \mathrm{~min}$ at RT and washed for $2 \times 5 \mathrm{~min}$ with PBS. For brightfield microscopy, the cells were counterstained with hematoxylin, washed with Milli $Q$, air-dried, and mounted in PBS/glycerol $(1: 9, v / v)$. For RCM, the cells were washed with Milli $Q$, not counterstained, air-dried, and stored at RT until use.

\section{PO-chloronaphthol reaction}

PO staining with $\mathrm{H}_{2} \mathrm{O}_{2}$ and 4-chloro-1-naphthol (Merck, Darmstadt, Germany) was performed as described by Nakane (1968). Briefly, $6 \mathrm{mg}$ chloronaphthol was dissolved in $0.2 \mathrm{ml} 100 \%$ ethanol and added to $10 \mathrm{ml} 0.05 \mathrm{M}$ Tris-HCl, $\mathrm{pH} \mathrm{7.6,}$ 
followed by filtering; just before use $10 \mu \mathrm{l} 30 \% \mathrm{H}_{2} \mathrm{O}_{2}$ was added. The preparations were incubated for $10 \mathrm{~min}$ at RT, and washed $2 \times 5$ min with Milli Q. For brightfield microscopy, the cells were counterstained with ethylgreen, dehydrated, and mounted in PBS/glycerol $(1: 9 \mathrm{v} / \mathrm{v})$. For RCM, the cells were not counterstained, air-dried, and stored at RT until use.

\section{PO-DAB reaction}

PO detection with $\mathrm{H}_{2} \mathrm{O}_{2}$ and DAB (Sigma) was performed as described by Graham and Karnovsky (1966), using 0.1 M imidazole (Merck) in the reaction mixture. After each PO-DAB reaction of $5 \mathrm{~min}$, the cells were rinsed in PBS. For brightfield microscopy, the cells were counterstained with hematoxylin, dehydrated, and mounted in Entellan (Merck). For RCM, the cells were dehydrated, not counterstained, airdried, and stored at RT until use.

\section{$P O-T M B$ reaction}

PO detection with $\mathrm{H}_{2} \mathrm{O}_{2}$ and 3,3',5,5'-tetramethylbenzidine (TMB; Sigma) was performed as described by Van der Loos et al. (1988) with slight modifications. In brief, $80 \mathrm{mg}$ dioctyl sodium sulfosuccinate (DSSS; Sigma) and $24 \mathrm{mg}$ TMB were dissolved in $10 \mathrm{ml} 100 \%$ ethanol at $60^{\circ} \mathrm{C}$. Just before use, $30 \mathrm{ml} 100 \mathrm{mM}$ citratephosphate buffer, $\mathrm{pH} 5.1$, and $10 \mu \mathrm{l} 30 \% \mathrm{H}_{2} \mathrm{O}_{2}$ were added. The preparations were incubated for $1-2 \mathrm{~min}$ at RT, washed $2 \times 1$ min with $50 \mathrm{mM} \mathrm{MgCl}$, and immediately blown dry by air for analysis by brightfield microscopy or RCM.

\section{Glucose oxidase cytochemistry}

\section{GO-NBT/PMS reaction}

Glucose oxidase (GO) detection was performed as described by Gown et al. (1986). In brief, the cells were incubated for $15-30 \mathrm{~min}$ at $37^{\circ} \mathrm{C}$ with a freshly prepared substrate solution (100 $\mu \mathrm{l} / \mathrm{slide})$ containing $0.05 \mathrm{M}$ Tris- $\mathrm{HCl}, \mathrm{pH} 8.5,13.5 \mathrm{mg} / \mathrm{ml} \beta$ D-glucose (Merck), $1.35 \mathrm{mg} / \mathrm{ml} \mathrm{NBT}$, and $0.25 \mathrm{mg} / \mathrm{ml}$ phenozine methosulphate (PMS; Sigma). Thereafter, the cells were washed $2 \times 5$ min with PBS and dehydrated. For brightfield microscopy, the cells were air-dried, counterstained with ethylgreen, dehydrated, and mounted in PBS/glycerol $(1: 9, v / v)$. For RCM, the cells were not counterstained, air-dried, and stored at RT until use.

\section{Embedding of enzyme cytochemically stained specimens}

\section{Mounting media}

Air-dried slides were mounted in aqueous-based mounting media, such as Aquamount (BDH, Poole, UK), Imsol (Klinipath, Zevenaar, The Netherlands), and PBS/glycerol $(1: 9 \mathrm{v} / \mathrm{v})$, or organic-based mounting media, such as Entellan, Fluoromount (BDH), and immersion oil (Zeiss). 


\section{Protein matrix}

Three approaches were tested to apply a protein matrix to cytochemical stained and air-dried preparations before mounting in immersion oil.

(1) Air-dried slides were briefly immersed in $20 \mathrm{mg} / \mathrm{ml}$ bovine serum albumin (BSA; Sigma) in Milli Q. After air-drying, the protein layer was fixed in $2 \%$ glutaraldehyde or formaldehyde (Merck) for $15 \mathrm{~min}$ at $4^{\circ} \mathrm{C}$. The slides were washed $2 \times 5 \mathrm{~min}$ in Milli Q and air-dried for 5-10 min (see Cornelese-ten Velde et al., 1988).

(2) Air-dried slides were briefly immersed in a freshly prepared protein-fixative mixture (20 $\mathrm{mg} / \mathrm{ml} \mathrm{BSA}, 2 \%$ gllutaraldehyde or $2 \%$ formaldehyde), and air-dried for $5-10 \mathrm{~min}$.

(3) Air-dried slides were smeared with $50 \mu 1$ protein-fixative mixture, containing 20 $\mathrm{mg} / \mathrm{ml} \mathrm{BSA}$ and $2 \%$ glutaraldehyde or $2 \%$ formaldehyde, and air-dried for $5-10$ $\min$.

\section{Microscopy}

\section{Brightfield microscopy}

Microphotographs from brightfield images were made on a Zeiss Axiophot microscope, using a Kodak Color Gold 100 ASA film in combination with blue and magenta filters.

\section{Fluorescence microscopy}

Microphotographs from APase-Fast Red fluorescence images were made on a Leitz Orthoplan microscope, equipped with a $100 \mathrm{~W}$ mercury-arc lamp and an appropriate filter set for Texas Red and tetramethylrhodamin isothiocyanate (TRITC) fluorescence, using a Scotch 3M 640 ASA film.

\section{Reflection contrast microscopy}

The Leitz Orthoplan microscope was also adapted for RCM (Cornelese-ten Velde et al., 1988). This involved the mounting of a polarization block (Leitz 513 791), containing a glassplate reflector and two fixed-crossed-polarizers. A reflection contrast objective (Zeiss, Antiflex-Neofluar objective; $x 63$, numerical aperture $(N A)=1.25$, oil), provided with a rotatable quarter lambda plate mounted on the front lens, was used in combination with a "central stop" device inserted in front of the collecting lens of the light-bulb (Leitz 520 508). The quarter lambda plate was adjusted to obtain maximum reflection. The light path in RCM is presented schematically in Figure 1, and this technique has been described in detail (Corneleseten Velde et al., 1988).

Briefly, a high intensity Xenon lamp (75 W) was used for illumination, since only a small percentage of the incident light is reflected. The cental stop device creates a ring-shaped light beam and, moreover, stops the light rays that otherwise would give the strongest reflections at the lens surfaces and would thus blur the ultimate RCM image. The incident light is polarized linearly by a $0^{\circ}$ polarizer and deflected in the 


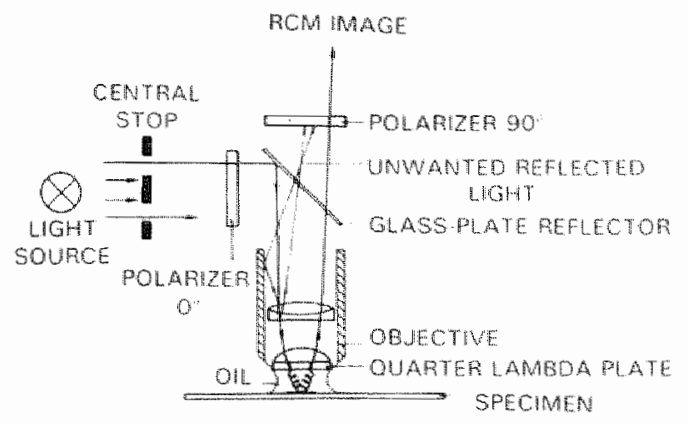

Figure 1. Schematic representation of the light path in the reflection contrast microscope (adapted. from Cornelese et al., 1988).

vertical light path by the glass-plate reflector. Light reflecting inside the microscope or at the lens surfaces are blocked by the crossed polarizer. Light that passes the quarter lambda plate becomes circularly polarized. After reflection at the specimen, light passes the quarter lambda plate again and is then linearly polarized and rotated $90^{\circ}$ with respect to the incident light, allowing it to pass the $90^{\circ}$ crossed polarizer. Immersion oil (refractive index 1.518) was applied between the objective and the glass slide to prevent reflection at the glass-air interphase. As a result, in principle, only the light reflected at the specimen contributed to the RCM image. Microphotographs from RCM images were made on Scotch 3M 640 ASA color film.

\section{RESULTS}

\section{Brightfield and fluorescence microscopy of enzyme precipitation products}

The APase, PO and GO detection procedures described in the 'Materials and Methods' were tested for effectiveness. For this purpose, T24 tumor cells were hybridized with the biotinylated DNA probe specific for the (sub)centromeric region of chromosome 1, resulting in three ISH signals in brightfield microscopy. All nine precipitated reaction products showed their specific absorption colors (Table 1), as can be seen in Figures $2 A-D$. The PO-DAB and PO-TMB reactions led to brown and green reaction products, respectively (Figures $2 \mathrm{~A}$ and $2 \mathrm{~B}$ ), whereas the APase-Fast Red and APase-NBT/BCIP reactions resulted in red and blue-purple precipitates, respectively (Figures $2 \mathrm{C}$ and $2 \mathrm{D}$ ).

Two of these reaction products, i.e., the APase-Fast Red and APase-New Fuchsin precipitates, showed fluorescent properties upon illumination with green light (550 nm) from a mercury-arc lamp (see Table 1 and Figures $2 \mathrm{G}$ and $2 \mathrm{I}$ for APase-Fast Red fluorescence). When using the BioGenex APase-Fast Red detection system, a higher sensitivity was achieved compared to the procedure described earlier (Speel et al., 1992b), but background fluorescence was also higher with the former method (data not shown). 
Talble 1 . Comparison of the color of various enzyme precipitates as revealed by different types of microscopy after encyme cytochemical detection of DNA probes in sin.

\begin{tabular}{|c|c|c|c|c|}
\hline \multirow[t]{2}{*}{ Enzyme } & \multirow[t]{2}{*}{ Enzyme reagents } & \multicolumn{3}{|c|}{ Microscopy } \\
\hline & & Brightfield & Reflection contrast & Fluorescence ${ }^{a}$ \\
\hline $\begin{array}{l}\text { APase } \\
\text { APase } \\
\text { APase } \\
\text { APase }\end{array}$ & $\begin{array}{l}\text { N-ASMX-P + Fast Red TR } \\
\text { BCIP + NBT } \\
\text { N-ASMX-P + New Fuchsin } \\
\text { NBT/BCIP/NT }\end{array}$ & $\begin{array}{l}\text { Red } \\
\text { Blue-Purple } \\
\text { Red } \\
\text { Brown }\end{array}$ & $\begin{array}{l}\text { Yellow } \\
\text { Orange Yellow } \\
\text { Yellowe } \\
\text { White }\end{array}$ & $\begin{array}{l}+ \text { (Red) } \\
+ \text { (Red) } \\
-\end{array}$ \\
\hline $\begin{array}{l}\mathrm{PO} \\
\mathrm{PO} \\
\mathrm{PO} \\
\mathrm{PO}\end{array}$ & $\begin{array}{l}\mathrm{H}_{2} \mathrm{O}_{2}+\mathrm{AEC} \\
\mathrm{H}_{2} \mathrm{O}_{2}+\text { Chloronaphtol } \\
\mathrm{H}_{2} \mathrm{O}_{2}+\mathrm{DAB} \\
\mathrm{H}_{2} \mathrm{O}_{2}+\mathrm{TMB}\end{array}$ & $\begin{array}{l}\text { Red } \\
\text { Purple } \\
\text { Brown } \\
\text { Green }{ }^{d, e} \text { Purple }\end{array}$ & $\begin{array}{l}\text { Yellow } \\
\text { White-Yellowe } \\
\text { Whited } \\
\text { Red }^{d} / \text { Yellow }^{\mathrm{d}}\end{array}$ & $\begin{array}{l}- \\
- \\
-\end{array}$ \\
\hline $\mathrm{GO}$ & $\mathrm{PMS}+\mathrm{NBT}$ & Blue-Purple & Yellow & - \\
\hline
\end{tabular}

-, not fluorescent; + , fluorescent.

b Abbreviations used: APase, alkaline phosphatase; $\mathrm{PO}_{y}$ horseradish peroxidase; $\mathrm{GO}$, glucose oxidase; $\mathrm{AEC}$, amino-ethyl-carbazole, BCIP, bromo-chloro-indolyl-phosphate; DAB, diaminobenzidine; N-ASMX-P, naphthol-ASMX-phosphate; NBT, nitro blue tetrazolium; PMS, phenozine methosulphate; NBT/BCIP/INT substrate, product name (Dako); TMB, tetramethylbenzidine.

- Fixation of enzyme precipitates in a protein matrix is essential; mounting in immersion oil.

"Fixation in a protein matrix is not essential; mounting in immersion oil.

${ }^{2}$ Color of the reaction product in air-dried slides or after mounting in PBS/glycerol.

Table 2. The solubility of different enzyme cytochemical reaction products in mounting media with a refractive index $n$ approximately equal to glass (Entellan, Fluoromownt, immersion oil) as compared to an aqueous mounting medium (PBS/glycerol, 1:9, w/W).

Enzyme reaction

Mounting medium

\begin{tabular}{|c|c|c|c|}
\hline $\begin{array}{c}\text { Entellan } \\
(n=1.495)\end{array}$ & $\begin{array}{c}\text { Fluoromount } \\
(\mathrm{n}=1.492)\end{array}$ & $\begin{array}{c}\text { Oil } \\
(n=1.518)\end{array}$ & PBS/glycerol \\
\hline
\end{tabular}

\footnotetext{
APase - Fast Red ${ }^{\mathrm{A}}$

APase - NBT/BCTP

APase - New Fuchsin

APase - NBT/BCIP/INT

PO- AEC

PO - Chloronaphtol

PO - DAB

PO - TMB

GO - NBT/PMS
}

$\begin{array}{ll}+b & + \\ +b & + \\ + & + \\ + & + \\ + & +\end{array}$

$\begin{array}{ccc}+ & + & - \\ + & + & - \\ + & + & - \\ + & + & - \\ + & + & - \\ + & - & - \\ - & + & - \\ + & + & \end{array}$

Abbreviations as described in Table 1.

${ }^{b}$ Reaction product dissolves very slowly (between 1 and $24 \mathrm{hr}$ ).

c Reaction product dissolves to a small extent in aqueous mounting media. 


\section{RCM detection of enzyme precipitation products}

The enzyme cytochemical $\mathrm{PO}-\mathrm{DAB}$ reaction product can be visualized by means of RCM. When the hybridization of the (sub)centromere 1-specific DNA probe and cytochemical detection were performed under optimal conditions (Cornelese-ten Velde et al., 1989), strong white reflection signals could be observed in both metaphase spreads and interphase nuclei (see Figures $2 \mathrm{E}$ and $2 \mathrm{~F}$ ).

When the other enzyme precipitates were tested by RCM, most of them dissolved rapidly in immersion oil, which is necessary to prevent reflection originating from the glass-air interphase (see Table 2). The sensitivity of both fluorescence nuicroscopy and RCM allowed us to monitor this dissolution process of the APase-Fast Red reaction product with time. Because of diffusion of the reaction product in immersion oil away from the site of precipitation, dark centres were observed within rings of the reaction product after a few minutes, as shown in Figures $2 \mathrm{G}$ and $2 \mathrm{H}$. The same area was viewed by means of both fluorescence microscopy, showing the red fluorescence of the precipitate (Figure 2G), and by RCM, showing a yellow reflection color for the APase-Fast Red reaction product. After $1 \mathrm{hr}$, the reaction product was completely dissolved in oil, and no further red fluorescence signals could be observed by means of fluorescence microscopy (data not shown). Also with RCM, no specific yellow reflection signal could be detected beyond $1 \mathrm{hr}$. Only the PO-TMB and the PO-DAB precipitates proved to be stable in immersion oill. However, an immediate change was observed in the absorption color of the PO-TMB reaction product from green to purple after addition of immersion oil to the air-dried slides and visualization by means of brightfield microscopy (see Table 1). Strikingly, some of the ISH signals showed the green color for a longer period of time before turning purple. This phenomenon could also be observed by RCM, as will be described below.

\section{Embedding of enzyme precipitates in a protein matrix for use in $\mathrm{RCM}$}

The use of aqueous-based mounting media, such as Aquamount, Imsol, and PBS/glycerol $(1: 9 \mathrm{v} / \mathrm{v})$, resulted in high background reflection in the RCM image (data not shown). Therefore, we first examined the possible usefulness of two other organic-based mounting media with a refractive index close to that of glass. However, both Entellan and Fluoromount yielded the same solubility problems as observed for immersion oil (see Table 2). A few of the reaction products tended to dissolve slowly in Entellan or oil, resulting in either diffusely stained nuclei or nuclei with only one or two weak signals instead of the three original strong ISH signals. These nuclei could not be accurately evaluated to determine the precise centromere copy number. Therefore, the feasibility was examined of other procedures to prevent the enzyme reaction products from being dissolved in oill.

We studied three approaches for applying a protein matrix to APase-Fast Red slained cell preparations. In a first approach, the slides were covered with a $20 \mathrm{mg} / \mathrm{ml} \mathrm{BSA}$ layer which was post-fixed in either $2 \%$ glutaraldehyde or $2 \%$ formaldehyde. The resulting protein matrix, however, was not sufficiently dense to prevent the precipitate from being dissolved in oil, resulting in the same pattern as in Figures $2 \mathrm{G}$ and $2 \mathrm{H}$. Another method of applying a protein matrix was tested by dipping and slowly 
withdrawing the slides from a BSA solution which already contained the fixative. This approach led to a fairly dense protein matrix on the slides, which protected the precipitate from contact with oil. However, the thickness of the matrix gave rise to interference patterns of reflected light, which were observed as disturbing color differences in the ultimate RCM image.

The third procedure tested was found to be preferable, whereby a small amount of BSA-fixative solution was smeared over the slides. The resulting protein matrix was then sufficiently dense to protect the APase-Fast Red precipitate from being dissolved in oil, but thin enough to prevent interference of light waves. As can be seen in Figures $2 \mathrm{~K}-\mathrm{T}$, such a protein matrix gives rise to a dark-blue RCM background image. Furthermore, we prefer to use glutaraldehyde in the BSA-fixative solution instead of formaldehyde, since the latter fixative tended to induce more disturbing color differences in the image as observed by $\mathrm{RCM}$.

\section{RCM detection of enzyme precipitates embedded in a protein matrix}

Table $\mathbb{1}$ shows the results of the nine enzyme reactions used, after application of a protein matrix to the cell preparations and analysis by means of RCM. Two main reflection colors could be observed with RCM, i.e., yellow and white. The precipitates that exhibited a red or blue-purple absorption color (APase-Fast Red, APase-NBT/BCIP, APase-New Fuchsin, PO-AEC, PO-chloronaphthol, GONBT/PMS) showed yellow reflection properties (Figures $2 K$ and $2 L$ ), whereas the reaction products with a brown absorption color (PO-DAB, APase-NBT/BCIP/INT) exhibited a clear white reflection, as can be seen in Figures $2 \mathrm{E}$ and $2 \mathrm{~F}$. The PO-TMB precipitate, which exhibited the green/purple color change in the brightfield image after mounting of the preparations in immersion oil, showed yellow reflection properties in the RCM image (Figure $2 \mathrm{M}$ ). However, in some cases a red reflection color could be observed (Figure 2N), corresponding to nuclei which still exhibited green ISH signals in the brightfield image. The green to purple color change in brightfield microscopy could be followed with RCM, resulting in nuclei that exhibited both red and clearly yellow ISH reflection signals (Figure 20).

\section{Sensitivity and application of the RCM technique for the detection of different DNA targets in situ}

The sensitivity of the RCM technique was determined by using DNA probes that detect smaller target sequences than the (sub)centromere $\mathbb{1}$-specific target. Probes for these smaller targets included the subtelomeric probe for chromosome 1 (p1-79) and the two cosmid probes of $40 \mathrm{~kb}$ for the $p$ and $q$ arms of chromosome 11 (cCI111-310 and -314 ). These biotinylated probes were detected with the APase-Fast Red reaction, after which the reaction product was fixed in a protein matrix and visualized by means of RCM. Figures $2 \mathrm{P}$ and $2 \mathrm{Q}$ show the detection of probe p1-79 and both cosmid probes, respectively. A strong yellow reflection of the precipitate is evident in a dark-blue background. These findings correspond to those where the sensitivity was tested with the PO-DAB reaction in metaphase spreads (Landegent et al., 1985b; Cornelese-ten Velde et al., 1989). 
When the PO-DAB and APase-Fast Red reactions were combined in a double-target ISH experiment, the presence of a biotinylated and a digoxigenin-labeled probe could be demonstrated simultaneously in T24 nuclei and in human lymphocyte metaphase preparations by means of RCM (Figures $2 \mathrm{R}-\mathrm{T}$ ). Again, it was essential to apply a protein matrix to the slides in order to prevent the APase-Fast Red precipitate from being dissolved in the immersion oil. This is demonstrated in Figure 2R: for each T24 nucleus three yellow APase-Fast Red signals (trisomy for the chromosome 1 centromere), which are already partly dissolved in oil (arrows), are shown in combination with three insoluble white PO-DAB signals (trisomy for chromosome 7 centromere; asterisks). Figures $2 \mathrm{R}$ and $2 S$ show, that it is important to fine-tune the incubation time of every enzyme reaction, since high densities of a reaction product resulted in the appearance of the absorption color in reflected light as white PO-DAB signals with a dark colored central area. Thus, two-colored ISH signals can be clearly visualized in one RCM image, showing the efficient combination of the white and yellow reflection colors for the detection of two different DNA targets (Figure 2T).

\section{DISCUSSION}

In this report we have shown that nine different enzyme reaction products, used to detect hybridized DNA probes in situ, can be efficiently visualized by means of RCM (Table 1). In most cases, RCM detection of the reaction products required that a thin protein matrix must be applied to the slides, in order to avoid the dissolution of these precipitates in the immersion oil. After application of such a matrix, the enzyme precipitates remained accurately localized during RCM analysis in both interphase and metaphase preparations. Moreover, the reflection signals from the different reaction products do not fade, thus enabling the preparations to be permanently stored.

\section{Embedding of enzymatically stained preparations in a protein matrix}

Fixation of the enzyme reaction products in a protein matrix has been demonstrated to be of great advantage, since seven of the nine reaction products dissolved in immersion oil when no matrix was applied. No alternative mounting media, showing a refractive index close to that of glass, were found to protect the precipitates from being dissolved. The most efficient approach for applying a protein matrix onto the ISH preparations consisted of spreading a small amount of a mixture of $20 \mathrm{mg} / \mathrm{ml}$ BSA and $2 \%$ glutaraldehyde over the slides. This approach led to a sufficiently thin matrix without interference patterns of light rays in the RCM image. As a result, a dark-blue RCM background image was observed. Sometimes slightly different reflection colors were observed, which may be the result of variations in the thickness of the protein matrix. Reduction of these variations in thickness, e.g., by mechanically withdrawing the preparations from a protein-fixative solution as described by Cornelese-ten Velde et al. (1988), may lead to a further standardization of this technique. 
Figure 2. ISH results in T24 cells $(A-D, F-O, R)$ and human lymphocyte metaphase spreads

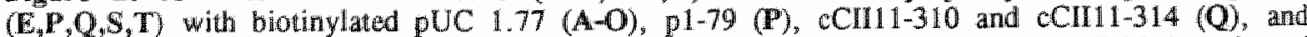
p7t $\lrcorner$. $(R)$ or $p 17 \mathrm{H} 8(\mathrm{~S}, \mathrm{~T})$ in combination with digoxigenin-labeled pUC 1.77 . Brightfeld detection of the brown PO-DAB precipitate (A), dark-green PO-TMB precipitate (B), red APase-Fast Red precipitate $(C)$, and blue purple APase-NBT/BCYP precipitate (D). (E, F) RCM detection of the PODAB precipitate without fixation in a protein matrix. (G) Fluorescence detection of the APase-Fast Red precipitate after mounting in immersion oil. (H) RCM image of $G$. (I) Fluorescence detection of the APase-Fast Red precipitate after fixation in arotein matrix and mounting in immersion ofl. (J) RCM image of I. (K-O) RCM detection of the APase-Fast Red precipitate (K), APase-NBT/BCIP precipitate (L), and PO-TMB precipitate (M-O) after fixation in a protein matrix and mounting in immersion oil. (B,Q) RCM detection of the APase-Fast Red precipitate after fixation in a protein matrix and mounting in immersion oil. (R-T) RCM detection of both the PO-DAB (white reflection) and $A$ Pase-Fast Red (yellow reflection) precipitates after fixation in a protein matrix and mounting in immersion oil. The significance of the arrows and asterisks shown on R-T is described in the "Results". Bars: A-D $=20 \mu \mathrm{m} ; \mathbf{E}, \mathbf{K}, \mathbf{L}, \mathbf{R}-\mathbf{T}=5 \mu \mathrm{m} ; \mathbf{F}=10 \mu \mathrm{m} ; \mathbf{G}-\mathbf{J}=10 \mu \mathrm{m} ; \mathbf{M}-\mathbf{O}=5 \mu \mathrm{m}$; $\mathrm{P}, \mathrm{Q}=5 \mu \mathrm{m}$.

\section{RCM image formation and color reflection}

In general, the reflection characteristics of an enzyme precipitate can be the result of two reflection phenomena, i.e., interference of reflected light rays and selective reflection of light of certain wavelengths (Cornelese-ten Velde et al., 1988). The first phenomenon is caused by refractive index differences between the mounting medium (oil) and the precipitate, resulting in reflection of all wavelenghts of the incident light by the precipitate. In fact, this phenomenon also accounts for the visualization of the unstained interphase nuclei and metaphase chromosomes in the RCM image.

The second reflection phenomenon plays a dominant role in the RCM images of cytochemically stained specimens (Van der Ploeg and Van Duijn, 1979). The reflection color of several stains was found to be mostly complementary to the color in the brightfield image. This was described for Giemsa and Feulgen stained specimens (Van der Ploeg and Van Duijn, 1979), but also observed for hematoxylin and ethylgreen stained chromosomes, which reflected orange-yellow and red light, respectively (Speel et al., unpublished). The reflection image of the PO-DAB reaction product, however, has been shown to be based on both reflection phenomena (Cornelese-ten Velde et al., 1988). Particularly the high refractive index of the PODAB precipitate $(n=1.55-1.60)$, compared to that of oill $(n=1.52)$, causes the interference of reflected light components to play a major role in the reflection image (Cornelese-ten Velde et al., 1988). Therefore, the PO-DAB precipitate reflects all the wavelengths of the incident xenon light, which results in a white reflection color.

RCM detection of the other reaction products resulted in either a white or a more yellow reflection color, depending on the precipitate (Table 1). Although to date we have not studied the contribution of the two reflection phenomena of these precipitates to the ultimate RCM image, it is most probable that the final reflection capacity of each precipitate is based on the ratio between these phenomena. On the basis of selective reflection alone, one would expect more pronounced differences in the reflection colors than were finally observed. This is probably due to reflection of all wavelengths at the precipitate because of differences in the refractive index (interference of reflected light). Moreover, the spectral composition of the illuminating 


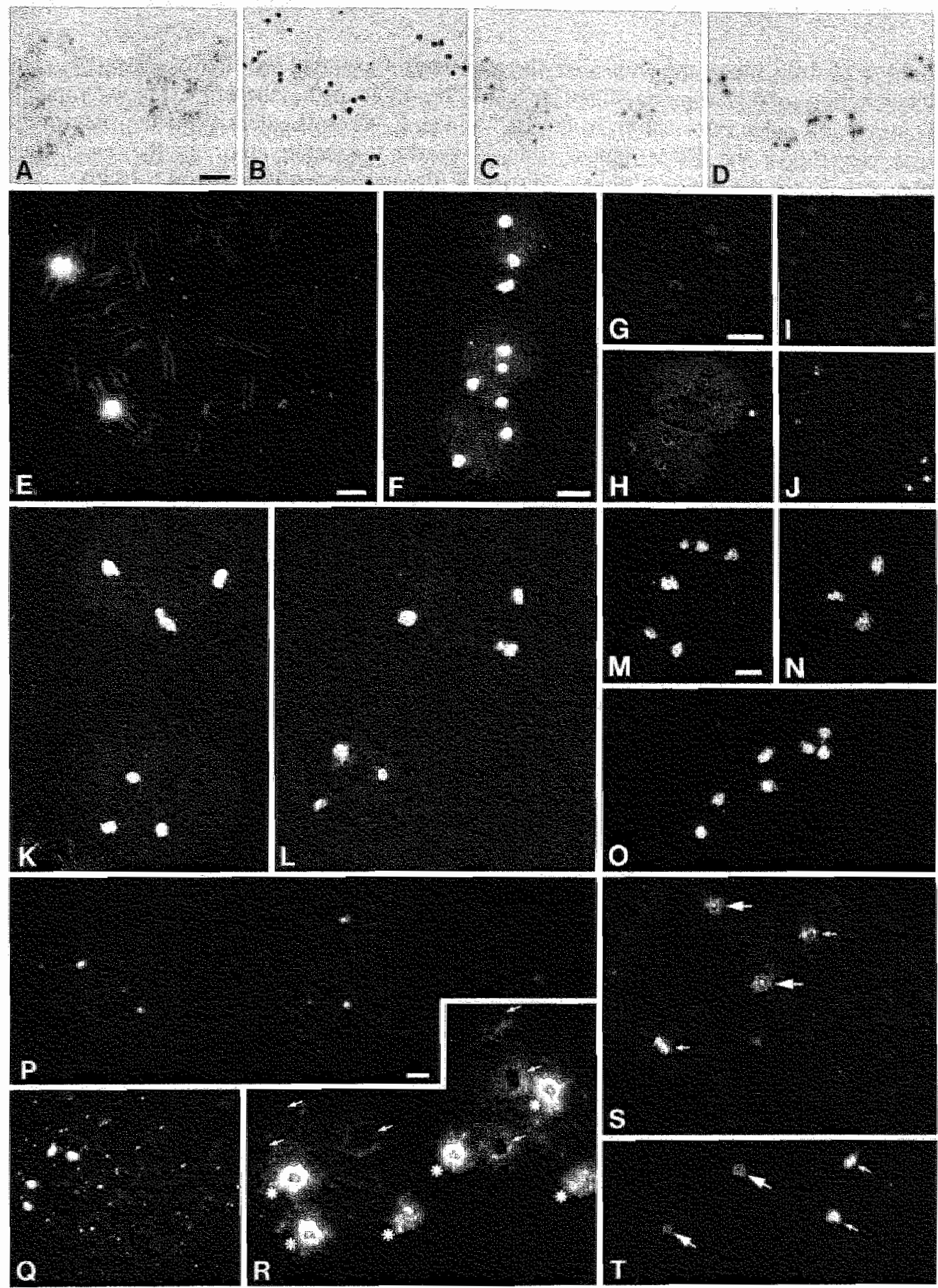


light also influences the color of the reflected light that is finally detected. The introduction of appropriate filter sets in the light path, therefore, may improve contrast and color information in the RCM image. When the density of the precipitate was very high, the RCM image showed nearly the same color as the brightfield image, because the incident light is absorbed (Cornelese-ten Velde et al., 1989).

The orange-yellow reflection color of the APase-NBT/BCIP precipitate was also reported by Cremers et al. (1987). However, these authors had problems with the discrete localization of the reaction product and, moreover, obtained a considerably higher background with this reaction as compared to the PO-DAB staining reaction. Since we found that the APase-NBT/BCIP precipitate dissolves in the immersion oil used, this finding probably explains the difficulties that these authors experienced with the use of this enzyme reaction to detect single-copy DNA sequences by means of RCM.

The PO-TMB reaction product was unstable in water and ethanol. Therefore, the preparations were air-dried immediately after the washing steps, followed by mounting in an organic-based medium such as oil, Entellan, or Fluoromount, in which the PO-TMB precipitate was stable and did not diffuse (see Table 2). We do not yet have an explanation for the color change observed after mounting of these slides. Especially the observed red reflection color of the PO-TMB precipitate would be a further improvement for the RCM procedure to be used in the simultaneous detection of multiple targets in one preparation. Since other procedures for the stabilization of the PO-TMB reaction product have been described (Liang and Wan, 1989; Weinberg and Van Eyck, 1991; Gu et al., 1992), we are now investigating these protocols for use in RCM.

\section{Sensitivity of the RCM technique}

The RCM technique presented in this report proved to be as sensitive as the procedures described earlier (Landegent et al., 1985b; Cornelese-te Velde et al,, 1989). Moreover, the application of a protein matrix to the stained slides provides, in principle, a method by which each enzyme cytochemical reaction product can be used for the RCM technique. This was exemplified by the detection of DNA target sequences up to the level of single-copy genes by means of the APase-Fast Red procedure, which would not have been feasible without the use of a protein matrix.

The sensitive RCM technique has its own intrinsic types of artefacts, e.g., dirt particles and small amounts of reaction product that are precipitated as a result of the aspecific binding of cytochemically introduced reagents (see Figures $2 \mathrm{E}, 2 \mathrm{H}$, and $2 Q$ ). These artefacts are rarely seen in brightfield microscopy, but may give rise to interpretative problems during RCM analysis.

\section{Application of the $\mathrm{RCM}$ technique}

Two enzyme reaction products that reflect incident light in different colors can now be visualized simultaneously in one RCM image when a protein matrix is applied. The combination of high sensitivity, multiple colors, and a relatively simple procedure make RCM an attractive method for the analysis of biological specimens. 
The technique can be applied with the same speed as conventional brightfield microscopy. However, in contrast to fluorescence microscopy, the time needed to fine-tune the different enzyme reactions may be a disadvantage of RCM. On the other hand, there is no problem of fading, since the enzyme precipitates proved to be stable upon exposure to excitation light as well as upon storage. The interest in methods using reflection microscopy, moreover, has increased due to the possibility of using confocal scanning laser microscopes in the reflection mode (Bianco and Boyde, 1989; Robinson and Batten, 1989; Szarowski et al., 1992). However, in these cases no color information is obtained as a consequence of the monochromatic laser light.

\section{Acknowledgements}

We would like to thank Dr HJ Tanke and Dr P wan Duijn (Department of Cytochemistry and Cytometry, University of Leiden, Leiden, The Netherlands) for critically reading the manuscript. This work was supported by the Netherlands Organization for Scientific Research NWO, grant no. 900-534-102, and Dako, and presented in part at the 9th International Congress of Histochemistry and Cytochemistry, August 30-September 5, 1992, in Maastricht, The Netherlands (Speel et al., 1992c).

\section{REFERENCES}

Ambros PF, Matzke MA, Matzke AJM (1986) Detection of a $17 \mathrm{~kb}$ unique sequence (T-DNA) in plant chromosomes by in situ hybridization. Chromosoma $94: 11-18$

Bianco P, Boyde A (1989) Alkaline phosphatase cytochemistry in confocal scanning light microscopy for imaging the bone marrow stroma. Bas Appl Histochem 33:17-23

Brigati DJ, Myerson D, Leary JJ, Spalholz B, Travis S, Fong CKY, Hsiung GD, Ward DC (1983) Detection of viral genomes in cultured cells and paraffin-embedded tissue sections using biotinlabelled hybridization probes. Virology 126:32-50

Bubenik J, Baresôvá V, Viklicky V, Jakoubkova J. Sainerová H, Donner J (1973) Established cell line of urinary bladder carcinoma (T24) containing tumour-specific antigen. Int I Cancer 11:765-773

Buroker N, Bestwick R, Haight G, Magenis RE, Litt M (1987) A hypervariable repeated sequence on human chromosome 1p36. Hum Cienet 77:175-181

Cooke HJ, Hindley J (1979) Cloning of human satellite III DNA: different components are on different chromosomes. Nucleic Acids Res 6:3177-3197

Cornelese-ten Velde I, Blonnet J, Tanke HJ, Ploem JS (1988) Reflection contrast microscopy: visualization of (peroxidase-generared) diaminobenzidine polymer products and its underlying phenomena. Histochemistry $89: 141 \times 150$

Cornelese-ten Velde I, Wiegant J, Tanke HJ, Ploem IS (1989) Improved detection and quantification of the (immuno)peroxidase product using reflection contrast microscopy. Histochemistry 92:153 160

Cornelese-ten Velde I, Prins FA (1990) New sensitive light microscopical detection of colloidal gold on ultrathin sections by reflection contrast microscopy. Combination of reflection contrast and electron microscopy in post-embedding immunogold histochemistry. Histochemistry 94:61-71 
Cremers AFM, Jansen in de Wal $N$, Wiegant $J$, Dirks $R$, Weisbeek $P$, Van der Ploeg $M$, Landegent JE (1987) Non-radioactive in situ hybridization. A comparison of several immunocytochemical detection systems wsing reflection-contrast and electron microscopy. Histochemistry $86: 609-615$

Dauwerse JG, Wiegant J, Raap AK, Breuning MH, Van Ommen G-JB (1992) Multiple colors by fluorescence in situ hybridization using ratio-labelled DNA probes create a molecular karyotype. Hum Mol Genet 1:593-598

Emmerich $P$, Loos $\mathbb{P}$, Jauch $A$, Hopman AHN, Wiegant J, Higgins MJ, White BN, Van der Ploeg $M$, Cremer $C_{*}$ Cremer $T$ (1989) Double in situ hybridization in combination with digital image analysis: a new approach to study interphase chromosome topography. Exp Cell Res 181:126-140

Garson $\searrow$ A, Van den Berghe JA, Kemshead IT (1987) Novel non-isotopic in situ hybridization technique detects small $(1 \mathrm{~kb})$ unique sequences in routinely G-banded human chromosomes: fine mapping of $\mathbb{N}$-myc and 6 -NGF genes. Nucleic Acids Res 15:4761-4770

Gown AM, Garcia R, Ferguson M, Yamanaka E, Tippens D (1986) Avidin-biotin-immunoglucose oxidase: use in single and double labeling procedures. I Histochem Cytochem 34:403-409

Graham RC, Lundholm U, Karnovsky MJ (1965) Cytochemïcal demonstration of peroxidase activity with 3-amino-9-ethyl carbazole. J Histochem Cytochem 13:150-152

Graham RC, Karnovsky MJ (1966) The early stages of absorption of injected horseradish peroxidase in the proximal tissues of mouse kidney with structural cytochemistry by a new technique. J Histochem Cytochem 14:291-302

Gu Y, Chen $Y, Y e \mathbb{L}$ (1992) Electron microscopical demonstration of horseradish peroxidase by use of tetramethylbenzidine as chromogen and sodium tungstate as stabilizer (TMB-ST method): a tracing method with high sensitivity and well preserved ultrastructural tissue. J Neurosei Methods 42:1-10

Hoefsmit ECM, Korn C, Blijleven N, Ploem JS (1986) Light microscopical detection of single 5 and $20 \mathrm{~nm}$ gold particles used for immuno-labeling of plasma membrane antigens with silver enhancement and reflection contrast. J Microsc 143; 161-169

Hopman AHN, Ramaekers FCS, Raap AK, Beek JLM, Devilee P, Van der Ploeg M, Vooijs GP (1988) In situ hybridization as a tool to study numerical chromosome aberrations in solid bladder tumors. Histochemistry $89 * 307-316$

Landegent JE, Jansen in de Wal N, Ploem JS, Van der Ploeg M (1985a) Sensitive detection of hybridocytochemical results by means of reflection-contrast microscopy. J Histochern Cytochem $33: 1241-1246$

Landegent JE, Jansen in de Wal N, Van Ommen G-JB, Baas F, De Vijlder JJM, Van Duijn P, Van der Ploeg M (1985b) Chromosomal localization of a unique gene by non-autoradiographic in situ hybridization. Nature 317:175-177

Lawrence JB, Villnave CA, Singer RH (1988) Sensitive, high-resolution chromatin and chromosome mapping in situ: presence and orientation of two closely integrated copies of EBV in a lymphoma line. Cell 52:51-61

Liang $F$, Wan XST (1989) Improvement of the tetramethyl benzidine reaction with ammonium molybdate as a stabilizer for light and electron microscopic ligand-HRP neurohistochemistry, immunocytochemistry and double-labelling. J Neurosci Methods 28:155-162 
Lichter $P$, Cremer $T$, Borden $J$, Manualidis $L$, Ward DC (1988) Deline

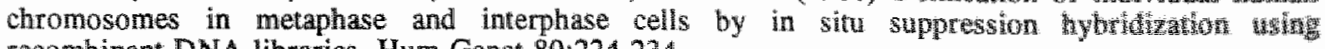
recombinant DNA libraries. Hum Genet 80:224-234

Lichter P, Boyle AL, Cremer T, Ward DC (1991) Analysis of genes and chrowosontses by nonisotopic in situ hybridization. Genet Anal Tech Appl 8:24-35

McGadey J (1970) A tetrazolium method for non-specific alkaline phosphatase. Histochemsisty 23:180-184

Nakane PK (1968) Simultaneous localization of multiple tissue antigens using the peroxidasetabeled antibody method: a study in pituitary glands of the rat. J Histochem Cytochem 16:557-560

Narayanswami $S$, Hamkalo BA (1991) DNA sequence mapping using electron microscopy. Genet Anal Tech Appl 8:14-23

Nederlof PM, Robinson D, Abuknesha R, Wiegant J, Hopman AHN, Tanke HJ, Raap AK (1989) Three-color fluorescence in situ hybridization for the simultaneous detection of multiple nudele acid sequences. Cytometry 10:20-27

Ploem IS (1975) Reflection contrast microscopy as a tool for investigation of the attachment of living cells to a glass surface. In Van Furth $R$ (ed): Mononuclear phagocytes in immunity, infection and pathology. Oxford, Blackwell Scientific Publications, pp 405-421

Raap AK, Hopman AHN, van der Ploeg M (1989) Hapten labeling of nucleic acid probes for DNA in situ hybridization. In Bullock GR, Petrusz P (eds): Techniques in immunocytochemistry, Vol 4. Cambridge, University Press, pp 167-197

Ried T, Baldini A, Rand TC, Ward DC (1992) Simultaneous visualization of seven different DNA probes by in situ hybridization using combinatorial fluorescence and digital imaging microscopy. Proc Natl Acad Sci USA 89:1388-1392

Robinson JM, Batten BE (1989) Detection of diaminobenzidine reactions using scanning laser confocal reflectance microscopy. J Histochem Cytochem 37:1761-1765

Seveus L, Väisălä M, Syrjänen S, Sandberg M, Knusisto A, Harju R, Salo J, Hemmilä I, Kojila H, Soini E (1992) Time-resolved fluorescence imaging of europium chelate label in immunohistochemistry and in situ hybridization. Cytometry 13:329-338

Speel EJM, Schutte B, Ramaekers FCS, Hopman AHN (1992a) The effect of avidin-biotin interactions in detection systems for in situ hybridization. J Histochem Cytochem $40: 135-141$

Speel EJM, Schutte B, Wiegant J, Ramaekers FCS, Hopman AHN (1992b) A novel fluorescence detection method for in situ hybridization, based on the alkaline phosphatase-fast red reaction. $J$ Histochem Cytochem 40:1299-1308

Speel EJM, Kamps M, Bonnet J, Ramaekers FCS, Hopman AHN (1992c) In situ hybridization based on reflection of different enzyme cytochemical reaction products (abstract). Histochem J $24: 560$

Szarowski DH, Smith KL, Herchenroder A, Matuszek G, Swann JW, Turner JN (1992) Optimized reflection imaging in laser confocal microsicopy and its application to neurobiology: modifications to the Biorad MRC-500. Scanning 14:104-111

Tokino T, Takahashi E, Mori M, Tanigami A, Glaser T, Park JW, Jones C, Hori T, Nakamura Y (1991) Isolation and mapping of 62 new RFLP markers on human chromosome 11. Am I Hum Gienet 48:258-268 
Trask BJ (1991) Fluorescence in siru hybridization: applications in cytogenetics and gene mapping. Trends Genet 7:149-154

Van der Loos C, Van den Oord J, Das P, Houthoff HJ (1988) Use of commercially available monoclonal antibodies for immunoenzyme double staining. Histochem J 20:409-413

Van der Ploeg M, Van Duijn P (1979) Reflection versus fluorescence. Histochemistry 62:227 232

Viegas-Pequignot E, Dutrillaux B, Magdelenat H, Coppey-Moisan M (1989) Mapping of single-copy DNA sequences on human chromosomes by in situ hybridization with biotinylated probes: enhancement of detection sensitivity by intensified-fluorescence digital-imaging microscopy. Proc Natl Acad Sei USA 86 "582-586

Waye JS, Willard HF (1986) Molecular analysis of a delection polymorphism in alpha satellite of human chromosome 17: evidence for homologous unequal crossing-over and subsequent fixation. Nucleic Acids Res 14:6915-6927

Waye JS, England SB, Willard HF (1987) Genomic organization of alpha satellite DNA on human chromosome 7: evidence for two distinct alphoid domains on a single chromosome. Mol Cell Biol $7: 349-356$

Weinberg RJ, Van Eyck SL (1991) A tetramethylbenzidine/tungstate reaction for horseradish peroxidase histochemistry. J Histochem Cytochem 39:1143-1148

Wiegant J, Ried T, Nederlof PM, Van der Ploeg M, Tanke HJ, Raap AK (1991) In situ hybridization with fluoresceinated DNA. Nucleic Acids Res 19:3237-3241 


\section{CHAPTER 5}

\section{A NOVEL TRIPLE-COLOR DETECTION PROCEDURE FOR BRIGHTFIELD MICROSCOPY, COMBINING IN SITU HYBRIDIZATION WITH IMNUNOCYTOCIEMISTRY}

Ernst JM Speel, Maurice PHM Jansen, Frans CS Ramaekers, Anton HN Hopman

J Histochem Cytochem 42, 1299-1307, 1994

\section{ABSTRACT}

We describe a fast light microscopic procedure for the simultaneous enzyme cytochemical detection of three different DNA target sequences in contrasting colors in both interphase and metaphase cell preparations. Chromosome-specific DNA probes labeled with either biotin, digoxigenin, or fluorescein were hybridized as a mixture and detected clearly and accurately by precipitates of the horseradish peroxidase-diaminobenzidine (PO-DAB, brown color), alkaline phosphatase-Fast Red (APase-Fast Red, red color), or horseradish peroxidase-tetramethylbenzidine (POTMB, green color) reaction, respectively. The PO-TMB reaction product was stabilized effectively by the addition of sodium tungstate to the reaction mixture, thus making the PO-TMB reaction now generally applicable to in situ hybridization (ISH). To avoid mixing of the precipitates of the two $P O$ reactions used in the triple-color ISH method, the first detected PO activity was always completely inactivated by a mild acid treatment before the second one was applied. Finally, the cell preparations were embedded in a thin protein layer cross-linked by formaldehyde to ensure permanent stabilization of the enzyme reaction products and optimal visualization of color contrast. The triple-color ISH detection procedure could be combined with Bgalactosidase-5-bromo-4-chloro-3-indolyl-B-D-galactoside immunocytochemistry, leading to the simultaneous localization of multiple DNA targets and a protein target in the same cell. The described procedure may, therefore, be a valuable tool in the areas of cytogenetics, cell biology, and molecular pathology. 


\section{INTRODUCTION}

Non-radioactive in situ hybridization (ISH) procedures using chromosome-specific DNA probes provide a powerful tool for the analysis of numerical and structural genomic aberrations in metaphase and interphase preparations of mammalian cells (Hopman et al., 1988; Lichter et al., 1991). Many non-radioactive detection systems have been described for ISH, of which the fluorescence and enzyme cytochemical procedures are most frequently used. These methods are based on visualization of in situ hybridized DNA probes, which are modified either directly (Wiegant et al., 1991) or indirectly (Raap et al., 1989; Hopman et al., 1995), with cytochemical detection layers of, for example, avidin and antibody conjugates carrying different tags for use in various types of microscopy (Emmerich et al., 1989; Nederlof et al., 1989; Narayanswami and Hamkalo, 1991; Seveus et al., 1992; Speel et al., 1993).

Since the introduction of fluorescence ISH by the end of the 1970s (Rudkin and Stollar, 1977; Bauman et al., 1980), this technique has been improved enormously and is now widely used because of its analytical speed and its high sensitivity and resolution (Trask, 1991). Moreover, various fluorochromes are now available that allow simultaneous detection of multiple DNA target sequences in different colors in only one preparation (Hopman et al., 1986; Nederlof et al., 1989; Dauwerse et al., 1992; Ried et al., 1992). Despite these advantages, fluorescence ISH has the disadvantage, that fading of the fluorescence signal takes place on exposure to light, although anti-fading reagents have been described that delay this proces to a large extent (Böck et al., 1985). We have recently reported the application of the sensitive alkaline phosphatase (APase)-Fast Red reaction to ISH, which results in a precipitate with a virtually permanent fluorescent character (Speel et al., 1992). However, a disadvantage of fluorescence ISH may also be the significant autofluorescence in, e.g., formalin-fixed, paraffin-embedded tissue sections. In addition, because of economical and practical considerations, the use of precipitating enzyme cytochemistry for ISH, combined with conventional brightfield microscopy, can be a valuable alternative to fluorescence ISH, especially, if permanent cell preparations with non-diffusable, non-fading reaction products can be combined with preservation of cell morphology.

Several authors have reported the successful application of double-target absorption ISH on cell preparations and tissue sections, utilizing both horseradish peroxidase (PO) and APase as the reporter enzymes (Hopman et al., 1986; Emmerich et al., 1989; Herrington et al., 1989; Mullink et al., 1989a; Gentilomi et al., 1992; Kerstens et al., 1994). In these cases, the two contrasting colors of the reaction products could be clearly distinguished by brightfield microscopy. In the fields of cytogenetics, molecular pathology, and cell biology, however, there still is an increasing need for techniques that allow demonstration of multiple targets (such as nucleic acid sequences) in the same specimens. Such a goal requires the use of different enzyme cytochemical reactions that possess both high sensitivity and precise localization properties and result in stable reaction products with contrasting colors. Moreover, rapid staining reactions are preferred so that the entire detection procedure can be 
performed within a few hours. The triple-staining protocols that have been described for immunocytochemistry (ICC) (Claassen et al., 1986; Van der Loos et al., 1987, 1989) are unsuitable for ISH. First, the localization properties of the B-galactosidase5-bromo-4-chloro-3-indolyl-B-D-galactoside ( $\beta$-Gal-BCIG) reaction in these procedures do not satisfy the conditions needed for ISH. Moreover, the molecular weight of BGal is very high $(500 \mathrm{kd})$, as a result of which we have as yet been unsuccessful in utilizing B-Gal conjugates for ISH (Speel, unpublished results). Second, in these ICC procedures, directly enzyme-labeled conjugates were used that may give rise to penetration problems if they are applied in the first ISH detection layer, resulting in diffuse, weak staining reactions (Speel et al., 1992). Since specific nucleic acid probes can now be labeled with biotin, digoxigenin, and fluorescein, such differently modified probes hybridized to immobilized target nucleic acids have been visualized simultaneously by three different colors in blots [rainbow system, (Hoeltke et al., 1992)]. In this system, the detection was carried out in consecutive APase-based reactions using three different naphthol-phosphate/diazonium salt combinations. However, the feasibility of this detection system for use in ISH remains to be established.

In the underlying study, a novel and relatively fast triple-color ISH method was developed for use in brightfield microscopy. For this purpose, we combined two PO reactions (PO-diaminobenzidine (DAB) and $\mathrm{PO}$-tetramethylbenzidine (TMB)) with one APase reaction (APase-Fast Red), since these enzyme reactions have proven to meet the criteria for application to ISH as described above (Speel et al., 1993). As a result of the simultaneous hybridization of a biotinylated, a fluoresceinated, and a digoxigenin-labeled DNA probe, the DNA target sequences were detected accurately by means of the contrasting colors brown (PO-DAB), green (PO-TMB), and red (APase-Fast Red). The application of the PO-TMB reaction to ISH was described by us only recently (Speel et al., 1993). This enzyme reaction, which is a modification of the procedure as described by Van der Loos et al. (1988), resulted in an unstable green precipitate. Only immediate air-drying after the reaction could preserve the green reaction product, whereas embedding of stained cell preparations in organicbased mounting media led to a change in the absorption color from green to purple. Therefore, we examined the efficacy of sodium tungstate to stabilize the PO-TMB reaction product, which was recently reported for use in neurohistochemistry (Weinberg and Van Eyck, 1991; Gu et al., 1992). The triple-color ISH detection procedure described here, in addition, could be combined with $\beta$-gal-BCIG ICC, providing a procedure for the simultaneous demonstration of one protein and three DNA targets in the same cell.

\section{MATERIALS AND METHODS}

\section{Cell processing}

Cell preparations from a $70 \%$ ethanol suspension of the human transitional cell carcinoma line T24 [DNA index 1.6; trisomic for the centromeres of chromosomes 1 
and 7 , tetrasomic for the centromere of chromosome 17 and the telomere of chromosome Ip; (Bubenik et al., 1973)], as well as steps necessary for removal of cytoplasm to improve DNA probe and conjugate penetration (pepsin digestion), were performed as previously described (Hopman et al., 1988; Speel et al., 1992).

Human umbilical vein endothelial (HUVE) cells were grown on coated glass slides in a 1:1 mixture of M199 (Gibco-BRL, Breda, The Netherlands) and RPMI 1640 (Gibco-BRL) media containing $20 \%$ pooled human serum, $10 \mathrm{ml} / \mathrm{liter}$ of a crude bovine brain extract, and $200 \mathrm{IU} / \mathrm{mm}$ of heparin sodium salt. Coating of the slides to which the cells were attached was performed by application of $200 \mu 10.1 \%$ gelatin in demineralized water (Mill Q) to each dry, sterile slide for $30 \mathrm{~min}$ at room temperature (RT). After removal of excess gelatin, every slide was incubated with $200 \mu \mathrm{l} 2.5 \%$ glutaraldehyde in Milli Q for $15 \mathrm{~min}$ at RT, rinsed four times. with phosphate-buffered saline (PBS: $0.15 \mathrm{M} \mathrm{NaCl}, 10 \mathrm{mM}$ sodium phosphate, $\mathrm{pH}$ 7.2), and finally coated with $200 \mu \mathrm{l} 150 \mu \mathrm{g} / \mathrm{ml}$ fibronectin in Hanks buffered saline solution (Gibco-BRL) for $30 \mathrm{~min}$ at $37^{\circ} \mathrm{C}$. HUVE cells were fixed by dipping in cold methanol $\left(-20^{\circ} \mathrm{C}\right)$ for $5 \mathrm{sec}$ and acetone $\left(4^{\circ} \mathrm{C}\right)$ three times for $5 \mathrm{sec}$, and were stored at $-20^{\circ} \mathrm{C}$ until use.

\section{Preparation of metaphase spreads}

Chromosomes" were prepared from peripheral blood using phytohemagglutinin stimulation, hypotonic spreading, and fixation in methanol:acetic acid $(3: 1 \mathrm{v} / \mathrm{v})$. Pretreatment of the metaphase spreads with RNase A and pepsin, followed by postfixation in $1 \%$ formaldehyde in PBS, has been described previously (Lichter et al, 1991; Wiegant et al., 1991; Speel et al., 1992).

\section{DNA probes and labeling procedures}

The probes for the (peri)centromeric regions of the human chromosomes 1 (pUC 1.77), 7 (p7t1), and 17 (p17H8) have been described by Cooke and Hindley (1979), Waye et al. (1987), and Waye and Willard (1986), respectively. The human 1pspecific subtelomeric probe p1-79 was described by Buroker et al. (1987). The DNA probes were labeled with biotin-11-dUTP (Enzo Diagnostics, New York, NY, USA), digoxigenin-11-dUTP, or fluorescein-12-dUTP (Boehringer, Mannheim, Germany) in a standard nick-translation reaction and used in single-, double-; or triple-target ISH procedures.

\section{In situ hybridization procedure}

The DNA probes described above were used at a concentration of $0.4 \mathrm{ng} / \mu \mathrm{l}$ (pUC $1.77)$ or $1 \mathrm{ng} / \mu \mathrm{l}(\mathrm{p} 7 \mathrm{tl}, \mathrm{pl} 7 \mathrm{H} 8, \mathrm{pl}-79)$ and hybridized in different combinations in a hybridization buffer containing $60 \%$ formamide, $2 x S S C(0.3 \mathrm{M} \mathrm{NaCl}, 30 \mathrm{mM} \mathrm{Na}$ citrate), pH 5.0, 10\% dextran sulphate, $0.2 \mu \mathrm{g} / \mu \mathrm{l}$ herring sperm DNA as carrier DNA, and $0.2 \mu \mathrm{g} / \mu \mathrm{l}$ yeast tRNA as carrier RNA. Ten $\mu 1$ buffer was added to each slide under a coverslip $(20 \times 20 \mathrm{~mm})$. Denaturation was performed on the bottom of a metal box in a water bath at $70^{\circ} \mathrm{C}$ for $3 \mathrm{~min}$ and hybridization was performed overnight at $37^{\circ} \mathrm{C}$. The slides were washed twice for $10 \mathrm{~min}$ at $42^{\circ} \mathrm{C}$ with $60 \%$ 
formamide, $2 \times S S C$, pH 5.0, containing $0.05 \%$ Tween 20 , followed by two 5 -rwin washes with $2 \mathrm{xSSC}, \mathrm{pH} 7.0$, at $42^{\circ} \mathrm{C}$ and a 5 -min wash with $4 \mathrm{xSSC}$, $\mathrm{pH} 7.0$, containing $0.05 \%$ Tween 20 (Buffer A) at RT.

\section{Cytachemical detection procedures}

To reduce background staining in the cytochemical detection procedures, the slides were pre-incubated with $4 \times S S C$, pH 7.0 , containing $5 \%$ non-fat dry milk (Buffer $B$ ) for 10 min at $37^{\circ} \mathrm{C}$, followed by dipping in Buffer $\mathrm{A}$ (see above). For all the detection procedures, the avidin conjugates were diluted in Buffer $B$, and all the antibody conjugates were diluted in PBS containing $0.05 \%$ Tween 20 (Buffer C) and $2 \%$ normal goat serum (NGS). After each incubation step of $20-30 \mathrm{~min}$ at $37^{\circ} \mathrm{C}$, the slides were rinsed twice in Buffer A (avidin conjugates) or Buffer C (antibody conjugates).

\section{Single-target ISH}

\section{Green PO-TMB detection}

For single-target ISH, the biotinylated pUC 1.77 probe was detected by incubating the slides with a 1:50 dilution of PO-conjugated avidin (AvPO; Dako, Glostrup, Denmark), followed by the PO-TMB reaction protocol (see below). The cells were counterstained with hematoxylin, dehydrated, and mounted in Entellan (Merck, Darmstadt, Germany).

\section{Double-target ISH}

\section{Brown PO-DAB and red APase-Fast Red detection}

First the biotinylated pUC 1.77 probe was detected with one incubation layer of $A v P O$, followed by the PO-DAB reaction (see below). When the second probe was digoxigenin-labeled ( $\mathrm{p} 7 \mathrm{tl}$ ), the slides were incubated with monoclonal mouse antidigoxin (MADig, 1:2000; Sigma, St Louis, MO, USA). If a fluoresceinated probe was used ( $\mathrm{pl} 7 \mathrm{H} 8$ or $\mathrm{pl-79}$ ), detection was performed with monoclonal mouse antifluorescein (MAFITC, 1:500; Dako). The monoclonal antibodies (MAbs) were detected with APase-conjugated goat anti-mouse IgG (GAMAPase, 1:25; Dako), followed by the APase-Fast Red reaction (see below). The cells were counterstained with hematoxylin, washed in Milli Q, air-dried, and mounted in PBS/glycerol (1:9).

\section{Brown $P O-D A B$ and green $P O-T M B$ detection}

After detection of the biotinylated pUC 1.77 probe with PO-DAB as described above, the second probe was visualized by incubation with the appropriate MAb and a second layer of PO-conjugated rabbit anti-mouse IgG (RAMPO, 1:80; Dako), followed by the PO-TMB reaction (see below). PO activity still present after the PO$D A B$ reaction was inactivated by incubation of the slides in $0.01 \mathrm{~N} \mathrm{HCl}$ for 10 min at RT. The cells were counterstained with hematoxylin or ethyl green, dehydrated, and mounted in Entellan. 


\section{Triple-target ISH}

Brown PO-DAB, red APase-Fast Red, and green PO-TMB detection The general protocol for the triple-color in situ detection of three hybridized DNA probes that are modified with biotin, digoxigenin, and fluorescein is shown below. The total time, including wash steps is approximately $3 \mathrm{hr}$.

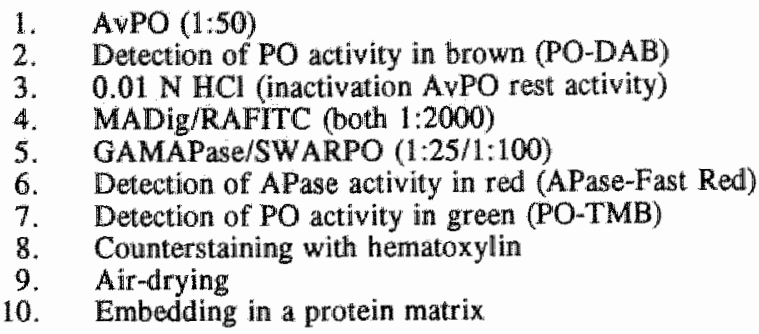

$\begin{array}{rr}20 \mathrm{~min} & 37^{\circ} \mathrm{C} \\ 5 \mathrm{~min} & 37^{\circ} \mathrm{C} \\ 10 \mathrm{~min} & \mathrm{RT} \\ 30 \mathrm{~min} & 37^{\circ} \mathrm{C} \\ 30 \mathrm{~min} & 37^{\circ} \mathrm{C} \\ 5-10 \mathrm{~min} & 37^{\circ} \mathrm{C} \\ 1-2 \mathrm{~min} & 37^{\circ} \mathrm{C} \\ 1 \mathrm{sec} & \mathrm{RT} \\ 10 \mathrm{~min} & \mathrm{RT} \\ 10 \mathrm{~min} & 37^{\circ} \mathrm{C}\end{array}$

In Figure 1c, a combination of biotinylated pUC 1.77, digoxigenin-labeled p17H8, and fluoresceinated $\mathrm{p} 7 \mathrm{tl}$ was used, whereas in Figures $1 \mathrm{~d}-1 \mathrm{~g}$ and $1 \mathrm{k}$ biotinylated $\mathrm{pUC}$ 1.77 was combined with digoxigenin-labeled $\mathrm{p} 7 \mathrm{tl}$ and fluoresceinated $\mathrm{p} 17 \mathrm{H} 8$. The cells were counterstained with hematoxylin, washed in Milli $Q$, air-dried, and embedded in a protein matrix as described previously (Speel et al., 1993). Briefly, the slides were smeared with $50 \mu \mathrm{l}$ of a mixture of $20 \mathrm{mg} / \mathrm{ml}$ bovine serum albumin (BSA; Sigma) in Milli Q and 2\% formaldehyde, and air-dried. Then, the slides could be analyzed directly or mounted optionally in an aqueous or organic mounting medium, or in immersion oil, with similar results.

\section{Combined immunocytochemistry and in situ hybridization}

The procedure used for combined ICC and ISH was performed as described previously (Speel et al., 1994). In short, HUVE cells were blocked with Buffer C containing $2 \%$ NGS for $10 \mathrm{~min}$, followed by an incubation for $45 \mathrm{~min}$ at RT with undiluted culture supernatant of MAb RV202, directed against the intermediate filament protein vimentin (Ramaekers et al., 1987). As a control, MAb RCK 102 was used, which was directed against human cytokeratin filaments 5 and 8 (Ramaekers et al., 1987). After washing three times for $3 \mathrm{~min}$ in Buffer $\mathrm{C}$, the mouse antibodies were detected by incubation with B-Gal-conjugated goat anti-mouse IgG (GAMB-Gal, 1:25; SBA, Birmingham, AL, USA) for $45 \mathrm{~min}$ at RT. The cells were washed three times for $3 \mathrm{~min}$ in PBS, followed by the B-Gal-BCIG staining reaction (see below). Thereafter, the cells were washed in $0.01 \mathrm{~N} \mathrm{HCl}$ for 2 min at $37^{\circ} \mathrm{C}$, digested with $100 \mu \mathrm{g} / \mathrm{ml}$ pepsin in $0.01 \mathrm{~N} \mathrm{HCl}$ for $20 \mathrm{~min}$ at $37^{\circ} \mathrm{C}$, washed again in $0.01 \mathrm{~N} \mathrm{HCl}$ for $2 \mathrm{~min}$, dehydrated, and post-fixed with $1 \%$ paraformaldehyde in PBS for $20 \mathrm{~min}$ at $4^{\circ} \mathrm{C}$. Cells were subjected to the ISH procedure as described above and were not counterstained in these cases. ISH on HUVE cells was performed as described above, omitting the steps for ICC. 


\section{Detection of enzyme activity}

\section{APase-FAST RED reaction}

APase detection was performed as described previously (Speel et al., 1992). In brief, $1 \mathrm{mg}$ naphthol-ASMX-phosphate (Sigma) in $250 \mu \mathrm{l} 0.2 \mathrm{M}$ Tris-HCl buffer, pH 8.5, containing $10 \mathrm{mM} \mathrm{MgCl}$ and $5 \mathrm{mg}$ Fast Red TR salt (Sigma) in $750 \mu l$ buffer, were subsequently added to $4 \mathrm{ml}$ buffer with $5 \%$ polyvinyl alcohol (PVA, Mw 40000; Sigma). This solution was gently mixed, after which each slide was incubated with $100 \mu \mathrm{l}$ of this reaction mixture under a coverslip for 5-10 min at RT. The slides were washed three times for $5 \mathrm{~min}$ with PBS.

\section{$\beta$-Gal-BCIG reaction}

B-Gal detection with 5-bromo-4-chloro-3-indolyl-B-D-galactoside (BClG; Life Technologies, Breda, The Netherlands) was performed as described by Bondi et al. (1982). In brief, $2.5 \mu \mathrm{l}$ of a stock solution of $20 \mathrm{mg} / \mathrm{ml}$ BClG in N,Ndimethylformamide was added to $100 \mu \mathrm{l}$ PBS containing $0.9 \mathrm{mM} \mathrm{MgCl}_{2}, 3 \mathrm{mM}$ potassium ferricyanide, and $3 \mathrm{mM}$ potassium ferrocyanide. Each preparation was incubated with this reaction mixture under a coverslip for $20-60 \mathrm{~min}$ at $37^{\circ} \mathrm{C}$ and washed three times for $5 \mathrm{~min}$ in PBS.

\section{$P O-D A B$ reaction}

PO detection with $\mathrm{H}_{2} \mathrm{O}_{2}$ and diaminobenzidine (DAB; Sigma) was performed as described by Graham and Karnovsky (1966), using 0.1 M imidazole (Merck) in the reaction mixture. After each PO-DAB reaction of $5 \mathrm{~min}$, the cells were rinsed twice for $5 \mathrm{~min}$ in PBS.

\section{PO-TMB reaction}

PO detection with $\mathrm{H}_{2} \mathrm{O}_{2}$ and 3,3',5,5'-tetramethylbenzidine (TMB; Sigma) was performed as described previously (Speel et al., 1993), with modifications. Briefly, $100 \mathrm{mg}$ sodium tungstate (Sigma) was dissolved in $7.5 \mathrm{ml} 100 \mathrm{mM}$ citrate-phosphate buffer, $\mathrm{pH} 5.1$, after which the $\mathrm{pH}$ was brought back to $\mathrm{pH} 5.0-5.5$ with $37 \% \mathrm{HCl}$. Just before use, $20 \mathrm{mg}$ dioctyl sodium sulfosuccinate (DSSS; Sigma) and $6 \mathrm{mg}$ TMB were dissolved in $2.5 \mathrm{ml} 100 \%$ ethanol at $80^{\circ} \mathrm{C}$ and added to the buffer together with $10 \mu l 30 \% \mathrm{H}_{2} \mathrm{O}_{2}$. The preparations were incubated with $100 \mu \mathrm{l}$ of this reaction mixture under a coverslip for 1-2 $\mathrm{min}$ at RT and washed three times for $1 \mathrm{~min}$ with $0.1 \mathrm{M}$ phosphate buffer, $\mathrm{pH} 6.0$, and $1 \mathrm{~min}$ with Milli Q.

\section{Brightfield microscopy}

Microphotographs were made on a Zeiss Axiophot microscope, using a Kodak Color Gold 100 ASA film in combination with blue and magenta filters. 


\section{RESULTS}

To develop a triple-target ISH detection procedure for brightfield microscopy, different combinations of two precipitating PO reactions (PO-DAB and PO-TMB) and one APase reaction (APase-Fast Red) were tested in several cell systems, including interphase preparations of T24 tumor cells or diploild HUVE cells and metaphase spreads of normal human peripheral lymphocytes (Table 1). The individual enzyme reactions have been described previously and are routinely applied to ISH. The POTMB reaction, however, first needed some adaptation owing to the poor stability of its reaction product.

\section{Modification of the PO-TMB reaction for ISH}

The PO-TMB reaction, described previously by us for use in ISH (Speel et al., 1993), was modified by the addition of $10 \mathrm{mg} / \mathrm{ml}$ sodium tungstate to the reaction mixture to stabilize the resulting green precipitate. T24 cells, hybridized with the biotinylated DNA probe specific for the (sub)centromeric region of chromosome 1 and stained with AvPO, showed three specific green ISH signals in brightfield microscopy (Figure 1a). A staining reaction of 1-2 min appeared to be optimal for distinct localization of the PO-TMB reaction product. The precipitate proved to be stable during the washing steps in phosphate buffer and Milli $Q$, as well as during the dehydration steps. The cells could be counterstained with hematoxylin, embedded in organic mounting medium, such as Entellan or mineral oil, and stored permanently at $4^{\circ} \mathrm{C}$. The PO-TMB reaction product was unstable in aqueous mounting media, such as PBS/glycerol (1:9) and Imsol (Klinipath, Zevenaar, The Netherlands), in which it dissolves rapidly. The high sensitivity of the PO-TMB reaction was demonstrated by the detectability of the telomere 1-specific DNA probe in T24 cells, using the same reaction time that was needed for the detection of the centromere probe (Figure 1b).

\section{Double-target ISH detection procedures}

\section{Brown PO-DAB and red APase-Fast Red detection}

The biotinylated and the digoxigenin-labeled DNA probes, specific for the (sub)centromeric regions of chromosomes 1 and 7 , respectively, were hybridized simultaneously to T24 and HUVE cells, and enzyme cytochemically detected by the PO-DAB and APase-Fast Red reaction as outlined in Table $\mathbb{1}$ (detection system 4). The contrasting colors of the brown PO-DAB and the red APase-Fast Red precipitates could be clearly distinguished in T24 cells, showing three ISH signals for both the centromeres of chromosomes 1 and 7 (shown in part in Figures 1d and 1e), as well as in HUVE cells, showing two ISH signals for both chromosomes (such as in Figure 1j). Cells were counterstained with hematoxylin and had to be embedded in aqueous mounting medium, since the APase-Fast Red reaction product is unstable in ethanol and organic-based mounting media (Table 1). The same results were obtained when both enzyme reactions (PO-DAB and APase-Fast Red) were performed after incubation of both enzyme conjugates. However, in that case the APase-Fast Red 
Table 1. Sequence of enzymatic detection systems (1-IIJ) in multiple-target ISH based on two PO and one APase detection systems ${ }^{a, b}$

\begin{tabular}{|c|c|c|c|c|c|}
\hline & $\begin{array}{c}\text { Detection } \\
\text { system }\end{array}$ & $\begin{array}{c}\text { PO-DAB } \\
\text { (brown) }\end{array}$ & $\begin{array}{c}\text { APase-Fast Red } \\
\text { (red) }\end{array}$ & $\begin{array}{c}\text { PO-TMB } \\
\text { (green) }\end{array}$ & Embedding \\
\hline Single-target ISH & $\begin{array}{l}1 \\
2 \\
3\end{array}$ & 1 & $\mathbb{1}$ & 1 & $\begin{array}{l}\text { Aqueous/organic } \\
\text { Aqueous } \\
\text { Orgunic }\end{array}$ \\
\hline Double-target ISH & $\begin{array}{l}4^{\mathrm{c}} \\
5^{\mathrm{d}, \mathrm{e}} \\
6^{\mathrm{e}}\end{array}$ & I & II & II & $\begin{array}{l}\text { Aqueous } \\
\text { Organic } \\
\text { Protein matrix }\end{array}$ \\
\hline Triple-target ISH & $7^{d, e}$ & I & II & III & Protein matrix \\
\hline
\end{tabular}

* The enzyme reactions were performed directly after the incubation with the appropriate enzyme conjugate. The incubations used are described in 'Materials and Methods". For each ISH detection system, the appropriate embedding medium is stated.

b Abbreviations used: APase, alkaline phosphatase; DAB, diaminobenzidine; ISH, in situ hybridization; $\mathrm{PO}$, horseradish peroxidase; TMB, tetramethylbenzidine.

- In case of enzyme activity detection after application of both enzyme conjugates, the reactions must be performed in the reversed order to prevent inactivation of APase by the PO reaction (Hopman et al., 1986).

dInactivation of the PO activity after the first $\mathrm{PO}$ reaction with $0.01 \mathrm{~N} \mathrm{HCl}$ is essential.

c The PO-TMB reaction must always be performed last, since the resulting precipitate proved to be unstable in aqueous solutions with a $\mathrm{pH}$ abowe pH 6 (e.g., Milli $\mathrm{Q}$ and PBS).

Embedding in a protein matrix is essential to prevent dissolving of the reaction products in an aqueous or organic mounting medium, or in immersion oill.

reaction was always performed before the PO-DAB reaction, since a reversed order decreased the APase activity significantly (Hopman et al., 1986).

\section{Brown $P O-D A B$ and green $P O-T M B$ detection}

$A$ combination of the $\mathrm{PO}-\mathrm{DAB}$ and $\mathrm{PO}$ TMB reaction could also be utilized for the visualization of two separately hybridized DNA probes in situ (Table 1, detection system 5). Figure $1 \mathrm{~b}$ shows the three brown (PO-DAB) ISH signals for the centromere of chromosome 1, together with four green (PO-TMB) signals for the telomere of this chromosome in T24 cells. Furthermore, the centromeric regions of chromosomes 1 and 7 were visualized with this double PO detection system in diploid HUVE cells (Figure 1i). The cells were counterstained with hematoxylin or ethyl green without losing color contrast and were embedded in organic mounting medium, since the PO-TMB reaction product is unstable in aqueous embedding media (Table 1). Inactivation of $P O$ activity after the $P O-D A B$ reaction was necessary before performance of the final $\mathrm{PO}-\mathrm{TMB}$ reaction, since omission of this inactivation step leads to mixing of the precipitates on the first detected DNA target (data not shown). Therefore, the slides were incubated with $0.01 \mathrm{~N} \mathrm{HCl}$ for $10 \mathrm{~min}$ at RT immediately after the PO-DAB reaction or after application of the second incubation layer. This procedure, which was described earlier by Nibbering et al. (1986), appeared to affect neither the final ISH results nor cell morphology. 


\section{Triple-target ISH detection procedure}

The PO-DAB, APase-Fast Red, and PO-TMB reactions were combined in a triplestaining procedure for simultaneous visualization of three centromere-specific DNA probes in different cell preparations (Table 1 , detection system 7). Figure $1 \mathrm{c}$ shows the centromeric regions of chromosomes 1,7 , and 17 in the contrasting colors brown (PO-DAB), green (PO-TMB), and red (APase-Fast Red), respectively。 in T24 cells that are not counterstained. Evidently, T24 cells contain three copies of the centromeres of chromosomes 1 and 7 and four copies of the centromere of chromosome 17. The same chromosomal regions are accurately discernible in brown, red, and green, respectively, in either $\mathrm{T} 24$ cells (Figures $1 \mathrm{~d}$ and 1e) or human metaphase spreads (Figures if and $1 \mathrm{~g}$ ) after counterstaining with hematoxylin. The copy numbers of the centromeric regions of chromosomes 1,7 , and 17 were in agreement with those in Figure 1c, whereas a disomy for these chromosomal regions was seen in the diploid metaphase spreads and lymphocyte nuclei (Figures $1 \mathrm{f}$ and $1 \mathrm{~g}$ ). The entire detection procedure, which can be performed within $3 \mathrm{hr}$, is outlined in "Materials and Methods". As already described for the double-target ISH, mild acid treatment was essential for inactivation of the first applied PO activity, whereas the PO-TMB reaction was always performed at the end of the detection procedure to ensure the stability of the reaction product (Table 1). Since the APase-Fast Red precipitate is unstable in ethanol and organic mounting media and the PO-TMB reaction product dissolves in aqueous mounting media, the cells were always air-dried after counterstaining and embedded in a protein matrix (Speel et al., 1993). The application of the protein matrix was essential to obtain a clear color contrast between the different enzyme precipitates. Moreover, this protein layer stabilizes the precipitates permanently and prevents them from being dissolved in any of the applied mounting media. Similarly, combination of the APase-Fast Red and PO-TMB detection systems for double-target ISH, as outlined in Table 1 (detection system 6), also requires application of a protein matrix to obtain permanent preparations.

\section{Combined ICC and multiple-target ISH}

Since in the ISH procedure antigenic epitopes are likely to be destroyed, ICC was always applied before the ISH procedure. As a model system we used HUVE cells, which express the intermediate filament protein vimentin but do not contain cytokeratins. Application of the mouse anti-vimentin MAb could be visualized by the B-Gal-BCIG reaction, resulting in a specific blue vimentin staining pattern with reasonable fibrillar localization (see, e.g., Figures $1 \mathrm{~h}, 1 \mathrm{j}$, and $\| \mathrm{k}$ ). In contrast, no staining was observed when the mouse anti-cytokeratin MAb was used (data not shown). The B-Gal-BCIG reaction product appeared to be unaffected by the ISH procedure, as reported by others (Van den Brink et al., 1990; Robben et al., 1994). Therefore, the B-Gal-BCIG ICC could be combined with the absorption ISH methods described above. This is demonstrated, for example, in Figure $1 \mathrm{~h}$, in which vimentin was visualized simultaneously with both the centromeres of chromosomes 1 and 7 in diploid HUVE cells (ISH with double PO detection). To demonstrate the specificity of the ISH signals, the HUVE cells were also subjected to double-target ISH without 
prior ICC staining for vimentin (Figure 1i). All nuclei contained two copies for the centromeres of chromosomes 1 and 7, as also observed in Figure 1h. A better color contrast could be obtained, if the B-Gal-BCIG used for the visualization of vimentin was combined with double-target ISH using the PO-DAB (brown) and APase-Fast Red (red) detection systems (Figure 1j). Finally, the triple-color ISH method was combined with ICC, resulting in the simultaneous localization of the centromeres of chromosomes 1 (brown), 7 (red), and 17 (green), together with vimentin (blue) in the cytoplasm of diploid HUVE cells (Figure $1 \mathrm{k}$ ).

\section{DISCUSSION}

We report here the development of a new and rapid triple-color ISH detection procedure for the simultaneous detection of three chromosome-specific DNA sequences by brightfield microscopy in interphase nuclei and metaphase preparations. A combination of three DNA probes, labeled with either biotin, digoxigenin, or fluorescein, could be hybridized simultaneously, since the cytochemical detection layers used are unrelated and do not interfere with each other. Distinct localization of the DNA probes was accomplished within $3 \mathrm{hr}$ by consecutive application of three sensitive enzyme cytochemical reactions, i.e., PO-DAB, APase-Fast Red, and POTMB (Table 1). Since the optimal conditions for each of these reactions were different, they had to be performed in succession. The reactions resulted in clearly contrasting and discernible brown, red, and green precipitates, respectively.

The present results have demonstrated that the PO-TMB reaction product can be efficiently stabilized with the addition of sodium tungstate to the reaction mixture, resulting in discretely localized green ISH signals. The reaction is extremely fast and sensitive, since incubation for 1-2 min proved to be sufficient for localization of both centromere- and telomere-specific DNA probes. Therefore, this reaction can be considered as an interesting alternative to the frequently used PO-DAB reaction in terms of reaction velocity and sensitivity. Because the pl-79 probe for the (sub)telomeric region of chromosome 1 hybridizes with a repetitive target DNA sequence of only some $100 \mathrm{~kb}$ (Buroker et al., 1987), the brightfield detection of yeast artificial chromosomes (YACs) and, eventually, cosmid probes with the POTMB reaction may now be within reach. We are now investigating the feasibility of applying this detection procedure in combination with brightfield microscopy.

The introduction of the PO-TMB reaction has considerably improved the multiplicity of color combinations for ISH. The PO-TMB reaction can be combined efficiently with both the PO-DAB and the APase-Fast Red reaction, resulting in an extension of detection methods to double-target ISH as well as to the development of the tripletarget ISH method for brightfield microscopy. However, the utilization of two PO and one APase detection procedures in one protocol requires some specific adaptations. First, the activity of the firstly applied PO conjugate may pose a serious problem in the second PO reaction. Therefore, the enzyme activity of the first detection round must be irreversibly inactivated. This could be achieved by a brief $0.01 \mathrm{~N} \mathrm{HCl}$ 
Figure 1. Brightfield detection of (a) single-target, (b,h-j) double-target, and (c-g,k) triple-target ISH in T24 cells (a-e), human lymphocyte metaphase spreads $(\mathbf{f}-\mathbf{g})$, and HUVE cells (h-k). Some of these cell preparations were immunocytochemically stained for vinentin before the ISH procedure ( $h, j, k$ ). Nuclei were counterstained with hematoxylin $(a, b, d-g)$ or ethylgreen (i). DNA probes used were: pUC 1.77 biotin (a), pUC 1.77 biotin in combination with either $p 1-79$ fluorescein (b) or p7t1 digoxigenin (h-j), pUC 1.77 biotin in combination with either p7t fluorescein and p17H8 digoxigenin (c), or p7t1 digoxigenin and p17H8 fluorescein $(\mathrm{d}-\mathrm{g}, \mathrm{k}$ ). (a) Detection of the (sub)centromeric region of chromosome 1 in green (PO-TMB). (b) Detection of the (sub)centromeric and (sub)telomeric regions of chromosome 1 in brown (PO-DAB) and green (PO-TMB), respectively. (c) Detection of the (sub)centromeric regions of chromosomes 1,7 , and 17 in brown (PO-DAB), green (PO-TMB), and red (APase-Fast Red), respectively. (d-g) Detection of the (suby)entromeric regions of chromosomes 1,7 , and 17 in brown (PO-DAB), red (APase-Fast Red), and green $(\mathrm{PO}-\mathrm{TMB})$, respectively. (h) Simultaneous detection of the intermediate filament protein vimentin in blue (B-Gal-BCIG) and the (sub)centromeric regions of chromosomes 1 and 7 in brown (PO-DAB) and green (PO-TMB). (ii) Similar detection of the chromosomal regions as seen in $h$

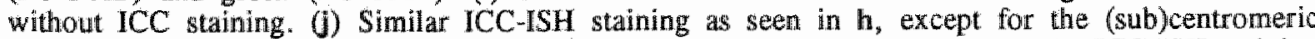
region of chromosome 7, which is now shown in red (APase-Fast Red). (k) Similar ICC-ISH staining as seen in $j$ with the extra detection of the (sub)centromeric region of chromosome 17 in green (POTMB). Bars: $-c, c-h, j-k=5 \mu \mathrm{m} ; \mathrm{d}=5 \mu \mathrm{m} ; \mathrm{i}=5 \mu \mathrm{m}$.

treatment of the cell preparations, which has been recommended by Nibbering et al. (1986) as an alternative to $\mathrm{H}_{2} \mathrm{O}_{2}$. This treatment appeared to have no apparent negative effect on the detection of the digoxigenin- and fluorescein-labeled probes or on cell morphology. Furthermore, the PO-DAB precipitate remained stable during the mild acid treatment, which has also been proven to be advantageous in combined ICC and ISH procedures (Mullink et al., 1989b).

Second, the triple-color ISH detection procedure requires embedding of the cell preparations in a thin protein layer, which appeared to be essential to obtain an optimal color contrast of the enzyme precipitates used. We have applied this approach previously for use in sensitive and multicolor reflection contrast microscopy (Speel et al., 1993). Since the PO-TMB reaction product is unstable in aqueous mounting media and the APase-Fast Red reaction product is unstable in an organic mounting medium, the embedding of the combination of both reaction products in a protein layer proved to be extremely useful, particularly since air-drying of the slides alone has been demonstrated to yield only poor color contrast of the enzyme precipitates. Moreover, the cell preparations could be permanently stabilized in this manner. In comparison with the multicolor rainbow detection system generally used for blot hybridization and described by Hoeltke et al. (1992), our ISH detection procedure can be performed within $3 \mathrm{hr}$, which is only half of the time required for the rainbow system. Furthermore, we use enzyme reactions that are specifically optimized for discrete localization of DNA sequences in situ. Moreover, the PO inactivation step with $0.01 \mathrm{~N} \mathrm{HCl}$ has no serious effect on cell morphology, whereas the repeated APase inactivation at $85^{\circ} \mathrm{C}$ performed in the rainbow system most probably is fatal for the preservation of cell morphology. Our new triple-color detection procedure for nucleic acid sequences in situ may, therefore, also be advantageous for use on blots with respect to time and localization properties. 

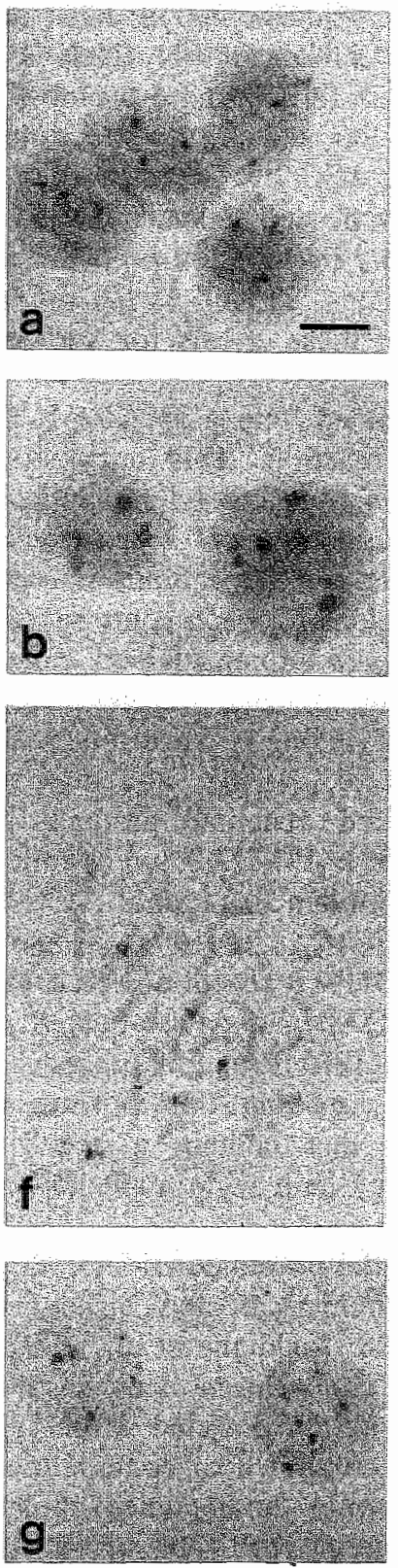
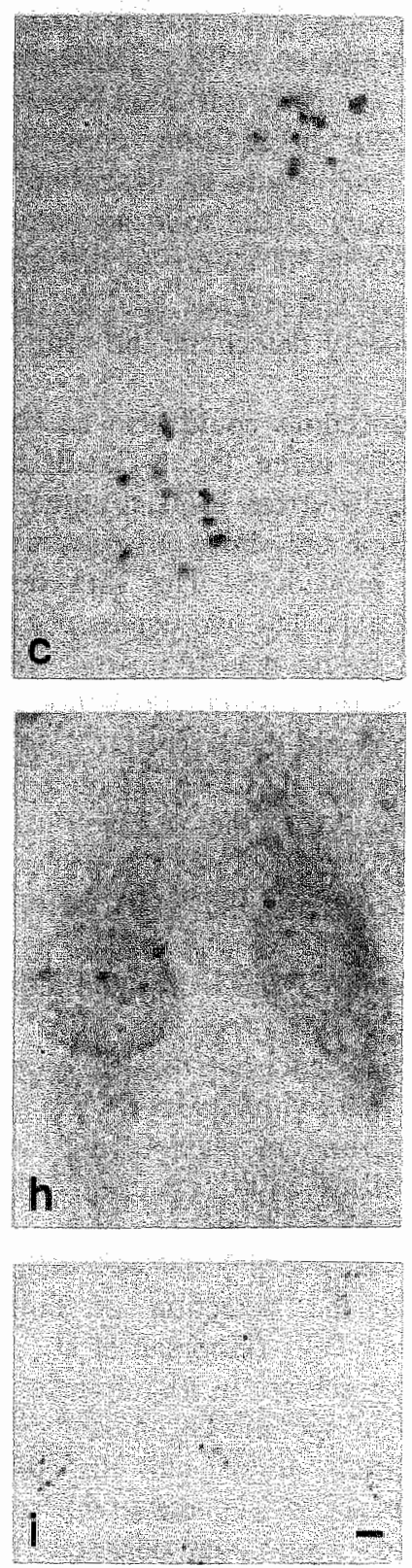
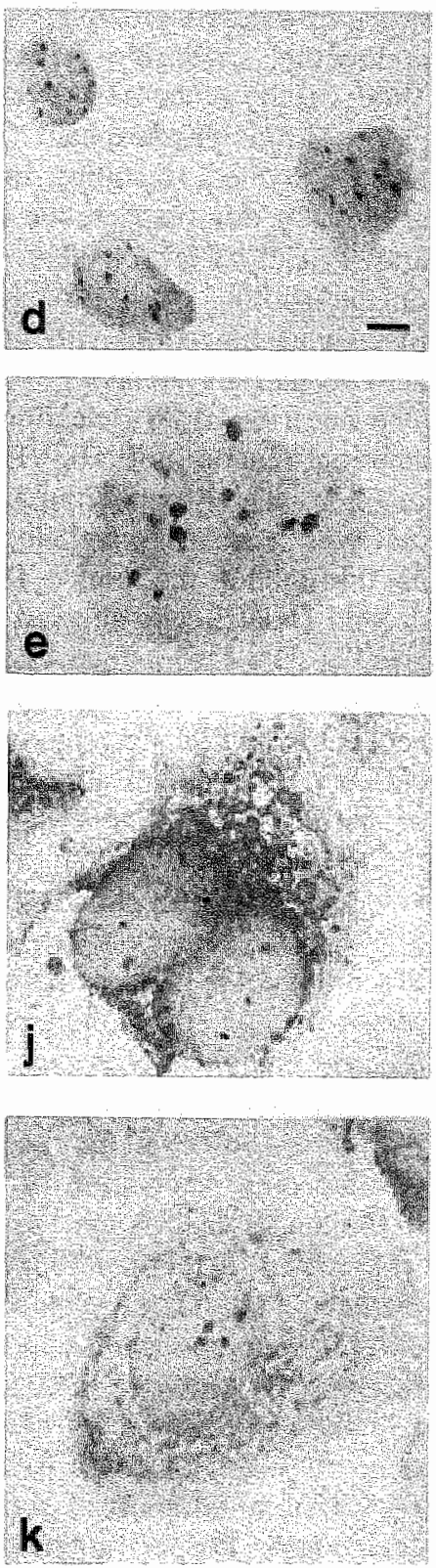
A further extension of colors for blot and in situ hybridization could be explored by utilizing colored precipitates that are generated by other PO chromophores, such as aminoethyl carbazole (AEC) (Graham et al., 1964) and chloronaphthol (Nakane, 1968), or by other APase reactions using nitroblue tetrazolium (NBT) and 5-bromo-4chloro-3-indolyl-phosphate (BCIP). In addition, combined PO and APase reactions can be applied, resulting in mixed colors as described for ICC by Claassen et al. (1986). In this respect, the efficacy of the mild acid treatment step to inactivate PO activity can be of help. However, the influence of the enzyme inactivation procedures on the stability of the precipitates and nucleic acid probe labels, as well as the order of enzyme detection, will ultimately determine the utility of these efforts for nucleic acid detection systems.

The described ISH detection procedure could also be combined with a specific ICC staining reaction of HUVE cells using the B-Gal-BCIG reaction. This enzymatic reaction, which could not be utilized for ISH, resulted in a blue indolyl precipitate that was reasonably well localized and stable on pepsin treatment at $\mathrm{pH} 2.0$, as well as throughout the entire ISH procedure. The ISH results on the immunostained diploid HUVE cells showed the expected two copies per nucleus for each centromerespecific DNA sequence tested, and when compared with non-immunostained cells. Therefore, the B-Gal-BCIG reaction product does not seen to make the cells less accessible to ISH reagents or to shield the target DNA. This finding is consistent with earlier reports (Van den Brink et al., 1990; Robben et al., 1994), and similar properties have been described for the APase-Fast Red reaction product if fluorescence analysis is preferred (Speel et al., 1994). The PO-DAB precipitate, however, has been shown to often shield the target DNA (Van den Brink et al., 1990; Strehl and Ambros, 1993).

Since the color contrast between the B-Gal-BCIG and the PO-TMB reaction product is relatively low, the combined ICC-ISH procedure with PO-DAB and APase-Fast Red is recommended. However, it is clear that the triple-color ISH detection procedure can also be efficiently combined with B-Gal-BCIG ICC, making this procedure extremely suitable for use in immunophenotyping cells that contain a specific chromosomal aberration or viral infection. Therefore, it may gain wide applicability in diagnostic pathology.

In the light of the developments in interphase cytogenetics, the presented tricolor ISH method can be of value for the detection of both numerical and structural chromosome aberrations in tumor cells (Hopman et al., 1988; Poddighe et al., 1992; Strehl and Ambros, 1993). As shown in Figures 1c-le, imbalances between the number of centromeric regions of specific chromosomes could be detected with high efficiency in T24 cells. In addition, almost all cells could be shown to contain four copies of a telomere 1-specific DNA sequence, whereas only three copies of the centromere 1-specific sequence could be detected (Figure 1b). This kind of chromosomal aberration can now be visualized easily with brightfield microscopy, bypassing the need for a fluorescence microscope. The application of the described triple-color ISH detection procedure for the study of tumor heterogeneity in tissue sections and cytological preparations, as well as chromosome aneuploidy in sperm 
cells, is now under investigation. Although the number of experiments as yet is limited, in all these cases the protocol could be used without any modification in the sequence of enzymatic reactions and reaction conditions.

\section{Acknowledgements}

We thank $J$ Albrechts for the preparation of metaphase spreads, and A van Geelen (Department of Microbiology, Academic Hospital Maastricht) for culturing the HUVE cells. This work was supported by the Netherlands Organization for Scientific Research NWO, grant no. 900-534-102.

\section{REFERENCES}

Bauman JGJ, Wiegant $J$, Borst $P_{*}$, Van Duijn P (1980) A new method for fluorescence microscopical localization of specific DNA sequences by in situ hybridization of fluorochrome labeled RNA. Exp Cell Res 128:485-490

Böck $G$, Hilchenbach $M$, Schauenstein $K$, Wick $G$ (1985) Photometric analysis of antifading reagents for immunofluorescence with laser and conventional illumination sources. I Histochem Cytochem 33:699-705

Bondi A, Chieregatti G, Eusebi V, Fulcheri E, Bussolati G (1982) The use of $\beta$-galactosidase as a tracer in immunacytochemistry. Histochemistry 76:153-158

Bubenk J, Baresová M, Vikllicky V, Jakoubkova J, Sainerova H, Donner J (1973) Established cell line of urinary bladder carcinoma (T24) containing tumour-specific antigen. Int J Cancer 11:765-773

Buroker N, Bestwick R, Haight G, Magenis RE, Litt M (1987) A hypervariable repeated sequence on human chromosome 1p36. Hum Genet 77:175-181

Claassen E, Boorsma DM, Kors N, Van Rooijen N (1986) Double-enzyme conjugates, producing an intermediate color, for simultaneous and direct detection of three different intracellular immunoglobulin determinants with only two enzymes. J Histochem Cytochem 34:423-428

Cooke HJ, Hindley J (1979) Cloning of human satellite III DNA: different components are on different chronosomes. Nucleic Acids Res 6:3177-3197

Dauwerse JG, Wiegant J, Raap AK, Breuning MH, Van Ommen GJB (1992) Multiple collors by fluorescence in situ hybridization using ratio-labelled DNA probes create a molecular karyotype. Hum Mol Genet 1:593-598

Emmerich P, Loos P, Jauch A, Hopman AHN, Wiegant J, Higgins MJ, White BN, Van der Ploeg $M$, Cremer $C$, Cremer $T$ (1989) Double in situ hybridization in combination with digital image analysis: a new approach to study interphase chromosome topography. Exp Cell Res $181: 126-140$

Gentilomi G, Musiani M, Zerbini M, Gibellinil D, Gallinella G, Venturoli S (1992) Double in situ hybridization for detection of Herpes simplex virus and Cytomegalovirus DNA using non-radioactive probes. J Histochem Cytochem 40:421 425

Graham RC, Karnowsky MJ (1966) The early stages of absorption of injected horseradish peroxidase in the proximal tubules of mouse kidney: ultrastructural cytochemistry by new technique. I Histochem Cytochem $14: 291-302$ 
Graham RC, Lundholm $U$, Karnowsky MJ (1964) Cytochemical demonstration of peroxidase activity with 3-amino-9-ethylcarbazole. J Histochem Cytochem 13:150-152

Gu Y, Chen Y, Ye L (1992) Electron microscopical demonstration of horseradish peroxidase by use of tetramethylbenzidine as chromogen and sodium tungstate as stabilizer (TMB-ST method): a tracing method with high sensitivity and well preserved ultrastructural tissue. J Neurosci Methods 42:1-10

Herrington CS, Burns J, Graham AK, Bhatt B, McGee JO'D (1989) Interphase cytogenetics using biotin and digoxygenin labelled probes II: simultaneous differentiall detection of human and papilloma virus nucleic acids in individual nuclei. IJ Clin Pathol 42:601-606

Hoeltke HJ, Ettl 1, Finken M, West $S$, Kunz W (1992) Multiple nucleic acid labeling and rainbow detection. Anal Biochem 207:24-31

Hopman AHN, Wiegant J, Raap AK, Landegent JE, Van der Ploeg M, Van Duijn P (1986) Bi-color detection of two target DNAs by non-radioactive in situ hybridization. Histochemistry $85: 1-4$

Hopman AHN, Ramaekers FCS, Raap AK, Beck JLM, Devilee P, Van der Ploeg M, Vooijs GP (1988) In situ hybridization as a tool to study numerical chromosome aberrations in solid bladder tumors. Histochemistry 89:307-31.6

Hopman AHN, Speel EJM, Voorter CEM, Ramaekers FCS (1995) DNA probe labelling methods. In Levy ER, Herrington CS (eds): Non-isotopic techniques in molecular biology: a practical approach. Oxford, IRL Press, University Press, in press

Kerstens HMJ, Poddighe PJ, Hanselaar GJM (1994) Double-target in situ hybridization in brightfield microscopy. J Histochem Cytochem 42:1071-1077

Lichter P, Boyle Al, Cremer T, Ward DC (1991) Analysis of genes and chromosomes by nonisotopic in situ hybridization. Genet Anal Tech Appl 8:24-35

Mullink. H, Walbooners JMM, Raap AK, Meyer CJLM (1989a) Two colour DNA in situ hybridization for the detection of two viral genomes using non-radioactiwe probes. Histochemistry 91:195-198

Mullink H, Walboomers JMM, Tadema TM, Jansen DJ, Meijer CJLM (1989b) Combined immunoand non-radioactive hybridocytochemistry on cells and tissue sections: influence of fixation, enzyme pre-treatment, and choice of chromogen on detection of antigen and DNA sequences. I Histochem Cytochem 37:603-609

Nakane PK (1968) Simultaneous localization of multiple tissue antigens using the peroxidase-labeled antibody method: A study on pituitary glands of the rat. J Histochem Cytochem 16:557-560

Narayanswami S, Hamkalo BA (1991) DNA sequence mapping using electron microscopy. Genet Anal Tech Appl 8:14-23

Nederlof PM, Robinson D, Abuknesha $R$, Wiegant J, Hopman AHN, Tanke HJ, Raap AK (1989) Three-color fluorescence in situ hybridization for the simultaneous detection of multiple nucleic acid sequences. Cytometry 10:20-27

Nibbering PH, Marijnen JGJ, Raap AK, Leijh PCI, Van Furth R (1986) Quantitative study of enzyme immunocytochemical reactions performed with enzyme conjugates immobillized on nitrocellulose. Histochemistry 84:538-543

Poddighe PI, Ramaekers FCS, Smeets AWGB, Vooijs GP, Hopman AHN (1992) Structural chromosome 1 aberrations in transitional cell carcinoma of the bladder: interphase cytogenetics combining a centromeric, telomeric, and library DNA probe. Cancer Res 52:4929-4934 
Raap AK, Hopman AHN, Van der Ploeg M (1989) Hapten labeling of nucleic acid probes for DNA in situ hybridization. In Bullock GR, Petrusz P (eds): Techniques in Immunocytochemistry, Vol 4. Cambridge, University Press, pp 167-197

Ramaekers F, Huysmans A, Schaart G, Moesker O, Vooijs P (1987) Tissue distribution of keratin 7 as monitored by a monocional antibody. Exp Cell Res 170:235-249

Ried T, Baldini A, Rand TC, Ward DC (1992) Simultaneous visualization of seven different DNA probes by in situ hybridization using combinatorial fluorescence and digital imaging microscopy. Proc Natl Acad Sci USA 89:1388-1392

Robben H, Van Dekken $H_{*}$ Poddighe PJ, Vooijs GP (1994) Identification of aberrant cells in cytological specimens by combined in situ hybridization and immunocytochemistry. Cytopathology $5: 384-391$

Rudkin GT, Stollar BD (1977) High resolution detection of DNA*RNA hybrids in situ by indirect immunofluorescence. Nature 265:472-473

Seveus L, Väisảlä M, Syrjänen S, Sandberg M, Kuusisto A, Harju R, Salo J, Hemmilä I, Kojola H,

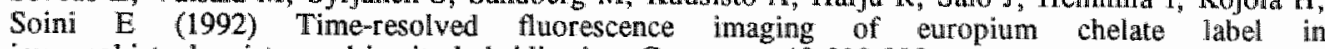
immunohistochemistry and in situ hybridization. Cytometry 13:329*338

Speel EJM, Schutte B, Wiegant J, Ramaekers FCS, Hopman AHN (1992) A novel fluorescence detection method for in situ hybridization, based on the alkaline phosphatase-fast red reaction. J Histochem Cytochem 40:1299-1308

Speel EJM, Kamps M, Bonnet J, Ramaekers FCS, Hopman AHN (1993) Multicolour preparations for in situ hybridization using precipitating enzyme cytochemistry in combination with reflection contrast microscopy. Histochemistry 100:357-366

Speel EJM, Herbergs J, Ramaekers FCS, Hopman AHN (1994) Combined immunocytochemistry and fluorescence in situ hybridization for simultaneous tricolor detection of cell cycle, genomic, and phenotypic parameters of tumor cells. J Histochem Cytochem 42, 961-966

Strehl S, Ambros PF (1993) Fluorescence in situ hybridization combined with immunohistochemistry for highly sensitive detection of chromosome 1 aberrations in neuroblastoma. Cytogenet Cell Genet $63 \div 24-28$

Trask BJ (1991) Fluorescence in situ hybridization: applications in cytogenetics and gene mapping. Trends Genet 7;149-154

Vam den Brink W, Van der Loos C, Volkers $H$, Lauwen $R$, Van den Berg F, Houthoff $H$, Das PK (1990) Combined $\beta$-Galactosidase and immunogold/silver staining for immunohistochemistry and DNA in situ hybridization. J Histochem Cytochem 38:325-329

Van der Loos CM, Das PK, Houthoff H-J (1987) An immunoenzyme triple staining method using both polyclonal and monoclonal antibodies from the same species. Application of combined direct, indirect and avidin-biotin complex (ABC) technique. J Histochem Cytochem 35:1199:1204

Van der Loos CM, Van den Oord JJ, Das PK, Houthoff H-J (1988) Use of commercially available monoclonal antibodies for immunoenzyme double staining. Histochem $\mathfrak{1} 20: 409-413$

Van der Loos CM, Das PK, Van den Oord JI, Houthoff H-J (1989) Multiple immunoenzyme staining techniques. Use of fluoresceinated, biotinylated and unlabelled monoclonal antibodies. J Immunol Methods 117:45-52 


\section{Chapter 5}

Waye JS, Willard HF (1986) Molecular analysiss of a deletion polymorphism in alpha satellite of human chromosome 17: evidence for homologous unequal crossing-over and subsequent fixation. Nucleic Acids Res 14:6915-6928

Waye JS, England SB, Willard HF (1987) Genomic organization of alpha satellite DNA on human chromosome 7: evidence for two distinct alphoid domains on a single chromosome. Mol Cell Biol $7: 349-356$

Weinberg RJ, Van Eyck SL (1991) A tetramethylbenzidine/tungstate reaction for horseradish peroxidase histochemistry. I Histochem Cytochem 39:1143-1148

Wiegant $\pi$, Ried $T$, Nederlof PM, Van der Ploeg M, Tanke HJ, Raap AK (1991) In situ hybridization with fluoresceinated DNA. Nucleic Acids Res 19:3237-3241 


\title{
CHAPTER 6
}

\section{COMBINED IMMUNOCYTOCFEMISTRY AND FLUORESCENCE IN SITU HYBRIDIZATION FOR SIMULTANEOUS, TRICOLOR DETECTION OF CELL CYCLE, GENOMIC, AND PHENOTYPIC PARAMETERS OF TUMOR CELLS}

\author{
Ernst JM Speel, Jos Herbergs, Frans CS Ramaekers, Anton HN Hopman \\ $J$ Histochem Cytachem 42, 961-966, 1994
}

\begin{abstract}
We describe the development and application of a sensitive high-resolution fluorescence alkaline phosphatase (APase)-Fast Red immunocytochemical (ICC) staining method in combination with fluorescence in situ hybridization (ISH) and bromodeoxyuridine (BrdU) detection. The high fluorescence intensity, accurate localization, and advantageous slowfading properties make the APase-Fast Red reaction a valuable tool for the detection of antigens or specific DNA probes in biological cell preparations. Since the enzyme precipitate proved to be resistant to enzymatic pre-treatment steps and stable during the entire ISH procedure, APase-Fast Red immunostaining could be combined with subsequent visualization of DNA target sequences by fluorescence ISH. The lung cancer cell lines NCI-H82 and EPLC 65 were used as a model system for simultaneous detection of cell proteins, such as the neural cell adhesion molecule (N-CAM), cytokeratin filaments, lamin, or the Ki67 antigen (Ki67-Ag), and centromere-specific DNA probes for the human chromosomes 1,7 , or 17. In addition, the combined ICC/ISH procedure could be extended with the immunodetection of BrdU incorporated by tumor cells in S-phase. As a consequence, a combined ICC/ISH/BrdU detection procedure is now available that enables analysis of relatively complex tumor populations on the basis of different ICC and genetic markers as well as proliferative activity.
\end{abstract}




\section{INTRODUCTION}

A variety of immunocytochemical (ICC) and in situ hybridization (ISH) methods give insight into the presence or absence of specific proteins and nucleic acid sequences or establish kinetic parameters of tumor cells. The combination of these techniques in the same biological specimen has proven advantageous in, e.g., demonstrating simultaneously the presence of mRNA and its protein product in one cell (Wolfson et al., 1985; Larsson and Hougaard, 1991; Dirks et al., 1993; Trembleau et al., 1993), immunophenotyping cells containing a specific chromosomal aberration or viral infection (Gendelman et 1. ., 1985; Porter et al., 1990; Losada et al., 1991; Van den Berg et al., 1991; Strehl and Ambros, 1993; Weber-Matthiesen el al., 1993), or characterization of cytokinetic parameters of tumor cell populations that are genetically or phenotypically aberrant (Schutte et al., 1987; Balazs et al., 1991; Van Dekken et al., 1991).

For a successful combination of ICC and non-radioactive ISH, several factors must be taken into account. Preservation of cell morphology and protein epitopes, accessibility of nucleic acid targets, and stability of enzyme cytochemical precipitates and fluorochromes all determine the success rate and sensitivity of the procedure. Since several steps in the ISH procedure, e.g., enzymatic digestion, post-fixation, denaturation at high temperatures, and hybridization in formamide, can destroy antigenic determinants, a combined procedure, starting with ICC and followed by ISH, is preferred in most cases. Several such combined ICC/ISH methods have been described with either enzyme precipitation reactions (Mullink et al., 1989; Porter et al., 1990; Van den Brink et al., 1990; Losada et al., 1991), fluorochromes (Van den Berg et al., 1991; WeberMatthiesen et al., 1993), or a combination of both (Strehl and Ambros, 1993). ICC detecion of proteins with stable enzyme reaction products allows optimal pre-treatment of the specimens before the ISH step.

Here we report on the usefulness of the alkaline phosphatase (APase)-Fast Red reaction in the ICC step before ISH. This detection method produces a strongly red fluorescent reaction product with a virtually permanent character that can be accurately localized under optimal conditions (Speel et al., 1992b). The resolution of the APase-Fast Red reaction was optimized for detection of DNA targets and for different cellular protein components. Once optimized, the APase-Fast Red reaction was utilized in both fluorescence ISH and combined ICC/ISH procedures. Finally, we combined the APaseFast Red antigen staining with fluorescence ISH and bromodeoxyuridine (BrdU) detection, thus allowing for the first time detection of phenotypic, genotypic, and cell kinetic parameters in the same cell.

\section{MATERIALS AND METHODS}

\section{Preparation of metaphase spreads}

Chromosomes were prepared from peripherall blood by phytohemagglutinin stimulation, hypotonic spreading, and fixation in methanol:acetic acid $(3: 1 \mathrm{v} / \mathrm{v})$. Pre-treatment of the metaphase spreads with RNase $\mathrm{A}$ and pepsin, followed by post-fixation in $\mathbb{\%}$ 
formaldehyde in phosphate-buffered saline (PBS: $0.15 \mathrm{M} \mathrm{NaCl}, 10 \mathrm{mM}$ Na phosphate, $\mathrm{pH} 7.2$ ), has been described previously (Speel et al., 1992b).

\section{Cell preparations and BrdU labeling}

Cell preparations were made from a cell suspension of human transitional cell carcinoma line T24 [DNA index 1.6; trisomic for the centromeres of chromosomes 1 and 7 ; (Bubenik et al., 1973)]. Fixation and removal of cytoplasm to improve DNA probe and conjugate penetration were performed as described earlier (Speel et al., 1992a). The human small-cell lung cancer cell line NCI-H82 and the human squamous-cell lung carcinoma cell line EPLC 65 were grown as described by Broers et al. (1988). BrdU labeling of cells was performed by adding BrdU to a final concentration of $10 \mu \mathrm{M}$ to the culture medium $30 \mathrm{~min}$ before harvesting of the cells. The floating NCI-H82 cells were cytospun onto glass slides (1000 rpm for $5 \mathrm{~min})$ and air-dried for $1 \mathrm{hr}$ at room temperature (RT). EPLC 65 cells were grown on glass coverslips for 2 days. Cells were fixed by dipping in cold methanol $\left(-20^{\circ} \mathrm{C}\right)$ for $5 \mathrm{sec}$ and acetone $\left(4^{\circ} \mathrm{C}\right)$ three times for $5 \mathrm{sec}$ and were stored at $-20^{\circ} \mathrm{C}$ until use.

\section{DNA probes and labeling procedure}

The probes for the (sub)centromeric regions of human chromosomes 1 (pUC 1.77), 7 (p7t1), and 17 (p17H8), as well as the cosmid clone cCII11-314, specific for $40 \mathrm{~kb}$ of DNA target on chromosome 11q23, have been described earlier (Cooke and Hindley, 1979; Waye and Willard, 1986; Waye et al., 1987; Tokino et al., 1991). The DNA probes were labeled with either biotin-11-dUTP (Enzo Diagnostics, New York, NY, USA), digoxigenin-11-dUTP, or fluorescein isothiocyanate (FITC)-12-dUTP (Boehringer, Mannheim, Germany) in a standard nick-translation reaction.

\section{ISH procedures}

The (sub)centromere probes and the cosmid probe were hybridized in single- and doubletarget ISH on metaphase spreads and on T24 cells, as described earlier (Speel et al., 1992a, 1993). After stringent post-hybridization washes, the digoxigenin-labeled probes were detected with subsequent detection steps of mouse anti-digoxin (MADig, 1:2000) (Sigma, St. Louis, MO, USA) and FITC-conjugated rabbit anti-mouse IgG (RAMFITC, 1:80) (Dako, Glostrup, Denmark), whereas the biotinylated DNA probes were detected by a three-step avidin-biotinylated enzyme complex $(A B C)$ detection system using the APase-Fast Red reaction (Speel et al., 1992b).

\section{ICC procedures}

The following polyclonal and monoclonal antibodies were used for the detection of cellular proteins: (a) a 1:5 dilution of affinity-purified polyclonal rabbit antibody raised against human skin cytokeratin filaments, which reacts with virtually all epithelial tissues (Ramaekers et al., 1983); (b) a 1:10 dilution of the monoclonal antibody (MAb) RCK102 to human cytokeratin filaments 5 and 8 (Broers et al., 1988); (c) a 1:10 dilution of an affinity-purified polyclonal rabbit antibody raised against the proliferation marker protein Ki67-Ag (Dako; a kind gift of Dr. J. Askaa); (d) a 1:5 dilution of MAb Ki67 (Dako); 
(e) undiluted culture supernatant of MAb LN43, directed against lamin B2 (a kind gift from Dr. E.B. Lane, Dundee, U.K.); and (f) undiluted culture supernatant of MAb RNL1, directed against the neural cell adhesion molecule N.CAM (Boerman et al., 1991).

For the ICC procedures, cells were first blocked with phosphate-buffered saline (PBS: $0.15 \mathrm{M} \mathrm{NaCl}, 10 \mathrm{mM}$ sodium phosphate, $\mathrm{pH} 7.2$ ) containing $0.05 \%$ Tween 20 (Buffer A) and $2 \%$ normal goat serum (NGS) for $10 \mathrm{~min}$, followed by incubation for $45 \mathrm{~min}$ at RT with the primary antibody. After three washes of 3 min each in Buffer A, the rabbit antibodies were detected by incubation with APase-conjugated swine anti-rabbit IgG (SWAR-APase, diluted 1:25) (Dako), whereas the mouse MAbs were detected with APase-conjugated goat anti-mouse IgG (GAM-APase, diluted 1:25) (Dako), all for 45 min at RT. All antibodies were diluted in Buffer A containing 2\% NGS. After three washes of 3 min each in $\mathbb{P B S}$, the APase-Fast Red staining reaction was performed as described earlier (Speel et al., 1992b). Polyvinyl alcohol was used to reduce diffusion of the final reaction product (see also Van Noorden and Vogels, 1989; Kiyama and Emson, 1991). In the case of EPLC 65 cells, a final concentration of $5 \mathrm{mM}$ levamisole (Sigma) was added to the reaction medium to inhibit endogenous APase. This was not necessary for the NCI-H82 cells. In all cases, control experiments with FITC-conjugated secondary antibodies were performed to reproduce the observed APase-Fast Red staining patterns.

\section{Combined ICC and fuorescence ISH}

ICC was always performed before the fluorescence ISH procedure. After APase-Fast Red immunostaining of the specific cell protein under investigation, the cells were washed in $0.01 \mathrm{M} \mathrm{HCl}$ for $2 \mathrm{~min}$ at $37^{\circ} \mathrm{C}$, digested with $100 \mu \mathrm{g} / \mathrm{ml}$ pepsin in $0.01 \mathrm{M} \mathrm{HCl}$ for 20 $\min$ at $37^{\circ} \mathrm{C}$, washed again in $0.01 \mathrm{M} \mathrm{HCl}$ for $2 \mathrm{~min}$, post-fixed in $1 \%$ paraformaldehyde in PBS for 20 min at $4^{\circ} \mathrm{C}$, and subjected to the ISH procedure as described above. The FITC-labeled probes could be detected directly, whereas the biotinylated probes were detected by subsequent incubation with amino methyl coumarin acetic acid (AMCA)-conjugated avidin (AvAMCA, diluted 1:100) (Vector, Brunschwig Chemie, Amsterdam, The Netherlands), biotinylated goat anti-avidin (BioGAA, diluted $1: 100)$ (Vector), and again AvAMCA. Fluorescence ISH without a preceding APase-Fast Red immunostaining was performed in the same way using one incubation step of FITCconjugated avidin (AvFITC, diluted 1:500) (Vector) for detection of biotinylated DNA probes.

\section{Simultaneous ICC, fuorescence ISH, and BrdU detection}

BrdU-labeled cells were subjected to APase-Fast Red immunostaining for detection of specific protein constituents and to ISH for detection of DNA targets as described above. The incorporated BrdU was detected by subsequent incubation with monoclonal mouse anti-BrdU (clone IIB5, diluted 1:10) (Schutte et al., 1987), biotinylated horse anti-mouse IgG (BioHAM, diluted 1:200) (Vector), and AvAMCA, with several washing steps in between. 


\section{Fluorescence microscopy and confocal scanning laser microscopy}

For fluorescence microscopy, cells were embedded in either $0.2 \mathrm{M}$ Tris- $\mathrm{HCl}, \mathrm{pH} 7.6$, or PBS, and glycerol $(1: 9 \mathrm{v} / \mathrm{v})$ containing $2 \%$ of the anti-bleaching reagent $1,4-\mathrm{di}$ azobicyclo-(2,2,2)-octane (DABCO; Sigma). In some cases, either $0.5 \mu \mathrm{g} / \mathrm{ml}$ of the DNA stain 4',6-diamino-2-phenyl indole (DAPI; Sigma) or Thiazole Orange (TO; Molecular Probes, Eugene, OR, USA) was included in the embedding medium.

Photomicrographs were made with either Fuji 400 ASA or Kodak Tmax 400 ASA films on a Zeiss Axiophot microscope, equipped with a $50 \mathrm{~W}$ mercury arc lamp and appropriate filter sets for red, green, and blue fluorescence.

The BioRad MRC 600 confocal scanning laser microscope (CSLM) imaging system equipped with a krypton/argon mixed-gas laser was used to produce the merged images of the APase-Fast Red staining in combination with the TO counterstaining.

\section{RESULTS}

\section{Accuracy and sensitivity of antigen and DNA target localization with the APase-Fast Red procedure}

Discrete localization of DNA targets and protein epitopes by the red fluorescent APaseFast Red precipitation product as the final detection step in ISH and ICC could be achieved, by varying the incubation time of this enzyme reaction in a medium with a low substrate concentration and by addition of polyvinyl alcohol, which is generally used to prevent diffusion of the precipitate (Van Noorden and Vogels, 1989; Kiyama and Emson, 1991; Speel et al., 1992b). An enzyme reaction time of $1-5$ min was sufficient for visualization of the DNA probe detecting the (sub)centromere region of chromosome 7 in metaphase spreads by ISH (Figure 1A). The cosmid probe specific for a $40 \mathrm{~kb}$ DNA target on the $\mathrm{q}$ arm of chromosome 11 could be detected after a 15-min APase-Fast Red enzyme reaction time (Figure $1 B$ ). Since preparations were analysed by CSLM, TO was used as the DNA counterstain, which shows a green fluorescence on exposure to the 488 nm laser line. This dye also emits green light on excitation with blue mercury arc light. The APase-Fast Red procedure was thus shown to be a sensitive method for detection of DNA sequences up to the levell of single-copy genes, and is of comparable sensitivity to other fluorescence ISH detection methods.

Similarly, accurate high-resolution images were obtained after APase-Fast Red immunostaining of various cell proteins. For example, cytoplasmic cytokeratin filaments and nuclear constituents, such as the proliferation marker Ki67-Ag, could be localized discretely with a high degree of resolution after an enzyme reaction time of $15 \mathrm{~min}$ (Figures 1C and 1D). Furthermore, specific APase-Fast Red staining patterns were demonstrated for the nuclear lamins in EPLC 65 cells (data not shown), N-CAM in NClH82 cells (Figure $1 \mathrm{G}$; enzyme reaction time $5 \mathrm{~min}$ ), and the sarcomeric protein titin in heart muscle, resolving a distance of approximately $0.5 \mu \mathrm{m}$ between two titin bands [Speel et al., 1994, BioRad (Richmond, CA, USA) Application Note No. 14]. 

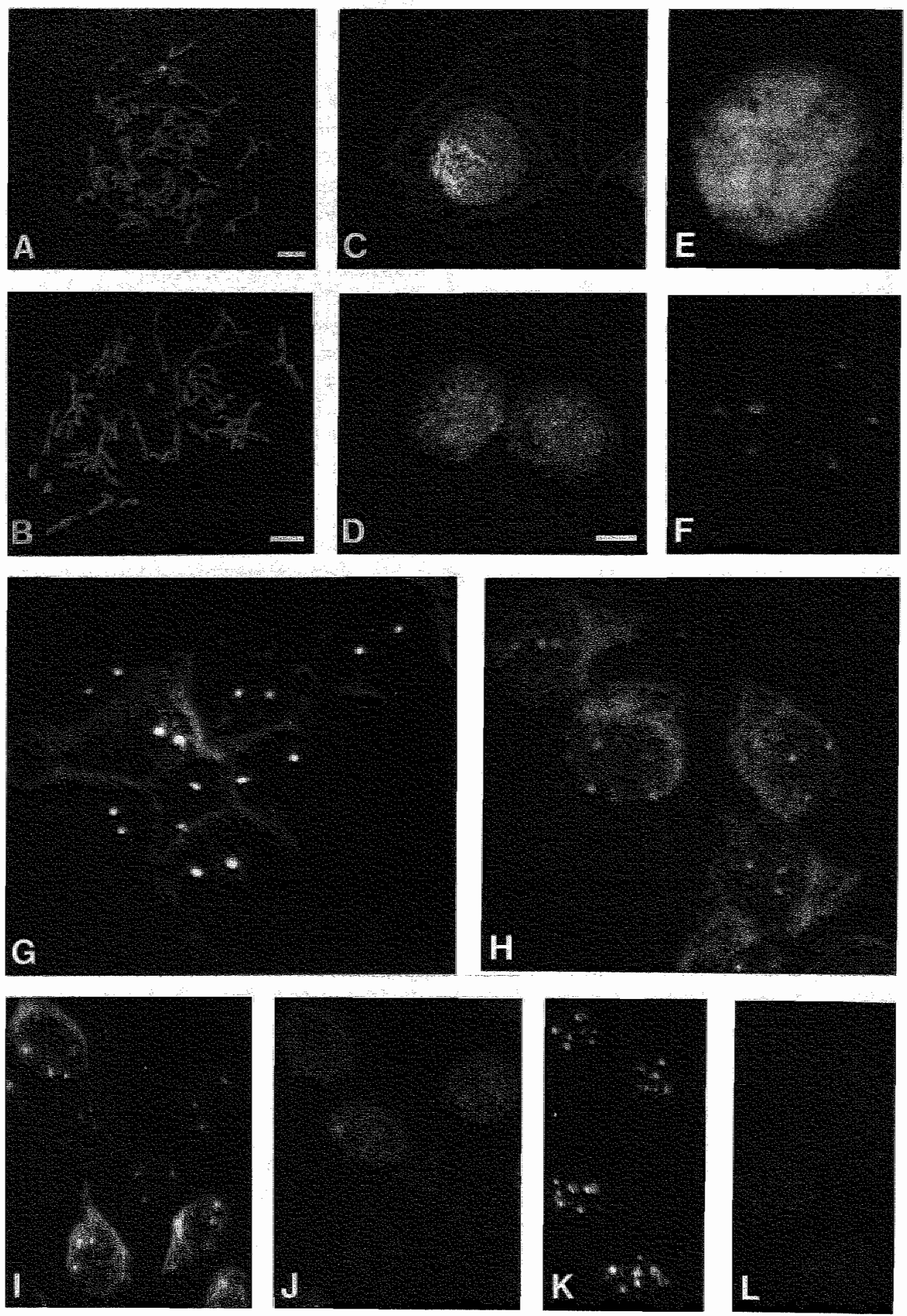
Figure 1. (A) Merged CSLM image of APase-Fast Red fluorescence for the (sub)centromeric region of chromosome 7 in a human lymphocyte metaphase spread, counterstained with TO. (B) Merged CSLM image of APase-Fast Red fluorescence for a cosmid on chromosome 11923 in a metaphase spread, counterstained with TO. (C) Merged CSLM image of APase-Fast Red staining of cytokeratin filamerts in EPLC 65 cells, counterstained with TO. (D) Merged CSLM image of APase-Fast Red fluorescence for the nuclear proliferation marker Ki67-Ag in EPLC 65 cells, connterstained with TO. (E) DNA staining of the same nucleus as in with DAPI fluorescence. (F) Sintultaneous fuorescence detection of the (sub)centromeric regions of chromosome I (FTC) and 7 (APase-Fast Red) in T24 cells. (G) Simultaneous fluorescence detection of the cell surface protein N-CAM (APase-Fast Red) and the (sub)centromeric region of chromosome 7 (FlTC) in NCI-H82 cells. (H) Simultaneous fluorescence detection of the cytokeratin filaments (APase-Fast Red) and the (sub)centromeric regions of chromosome 1 (AMCA) and 17 (FITC) in EPLC 65 cells. (I-L) Simultaneous fluorescence detection of specitic cellular proteins (APase-Fast Red), the (sub)centromeric region of chromosome 7 (FITC), and incorporated BrdU (AMCA) in EPLC 65 cells. The red APase-Fast Red fluorescence occasionally appears yellow because of co-localization with green ISH signals or saturation of the photographic film. (1) Keratins (APase-Fast Red) and trisomy for centromere 7 (FITC). (J) BrdU detection (AMCA) in the same cells as seen in I. (K) Nuclear proliferation marker Ki67-Ag (APase-Fast Red) and trisomy for centromere 7 (FITC). (L) BrdU detection (AMCA) in the same cells as seen in $\mathbf{K}$. Bars: $\mathbf{A}, \mathbf{G}, \mathbf{I}-\mathbf{L}=5$ $\mu \mathrm{m} ; \mathrm{B}, \mathrm{C}, \mathbb{E}, \mathrm{F}=5 \mu \mathrm{m} ; \mathrm{D}, \mathrm{H}=5 \mu \mathrm{m}$.

For detection of cytokeratin filaments and titin, addition of $5 \mathrm{mM}$ levamisole to the reaction medium was essential to inhibit endogenous APase in EPLC 65 and muscle cells. Control experiments were performed with FITC-conjugated secondary antibodies to check the specificity of the primary antibodies used. These stainings were similar to those obtained with the APase-Fast Red reaction (data not shown).

\section{Double-target fluorescence ISH based on the APase-Fast Red reaction and fluorescein-conjugated detection reagents}

The APase-Fast Red procedure could be combined with FITC fluorescence detection in a double-target ISH experiment to simultaneously visualize a biotinylated DNA probe next to a digoxigenin-labeled DNA probe in T24 nuclei (Figures $1 \mathrm{E}$ and $\mathrm{IF}$ ). As a result, three red (APase-Fast Red; trisomy for chromosome 7 centromere) and three green (FITC; trisomy for chromosome 1 centromere) ISH signals were observed by using the filter set for green fluorescence.

\section{Combined ICC with the APase-Fast Red reaction and double-target nuorescence ISI}

As mentioned before, in the combined ICC/ISH procedure, ICC was always applied before the ISH step, since in the latter procedure antigen epitopes are destroyed. Since the cytokeratin filaments or N-CAM staining patterns obtained with tetramethylrhodamine isothiocyanate (TRITC)-labeled secondary antibodies in the ICC step were dramatically influenced by the ISH protocol, the APase-Fast Red detection method was utilized in the ICC step before fluorescence ISH. The red fluorescence, resulting from the APase-Fast Red precipitate, was unaffected by the ISH procedure. This is demonstrated in Figure 1G, showing N-CAM being detected simultaneously with FITC-labeled centromeres for chromosome 7, and in Figure $1 \mathrm{H}$, visualizing cytokeratin filaments together with the centromeres of chromosome 1 (AMCA detection) and 17 (FITC detection). 
Table 1. Comparison of the frequency of fluorescence ISH signals/nucleus for chromosomes 1,7 , and 17 in single-target $1 S H$ and combined ICC/ISH ${ }^{\circ}$.

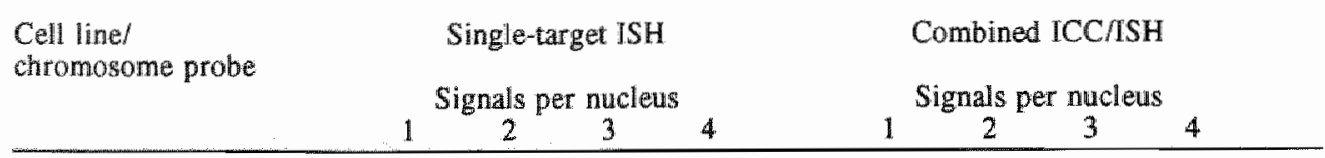

EPLC 65

probe 1

probe 7

probe 17

$\begin{array}{rrr}4 & 19 & 77 \\ 1 & 9 & 90 \\ - & 5 & 95\end{array}$

77
90
95

-

$\begin{array}{lrrr}1 & 21 & 78 & - \\ - & 5 & 92 & 3 \\ - & 4 & 95 & 1\end{array}$

NCL-H82

probe 7

$295 \quad 3$

$2 \quad 92 \quad 6$

a Analysis of one hundred intact and non-overlapping EPLC 65 or NCI-H82 nuclei by two independent obserwers did not result in significantly different results.

Although enzymatic digestion with pepsin was not essential for positive ISH results after APase-Frast Red ICC, the fluorescence intensity of the observed ISH signals was much higher after inclusion of such a pre-treatment step in the procedure. Furthermore, hybridization for $1-2 \mathrm{hr}$ at $37^{\circ} \mathrm{C}$ proved to be sufficient for detection of centromerespecific DNA targets, although the hybridization in most experiments was performed overnight at $37^{\circ} \mathrm{C}$.

To determine the influence of the ICC procedure on the observed number of ISH signals/nucleus, the lung cancer cells treated by ICC and ISH were compared with those subjected to single-target fluorescence ISH with the same DNA probes, except that all the probes were biotinylated and were detected with one layer of AvFITC. Table 1 shows the results of these comparative studies, in which 100 intact, non-overlapping nuclei were counted for each DNA probe by two independent investigators. The singletarget fluorescence ISH results correspond with those observed after performing the combined ICC/ISH method. The APase-Fast Red precipitation reaction, therefore, seems not to influence the results of the subsequent ISH procedure.

\section{Combined APase-Fast Red ICC, fluorescence ISH, and BrdU detection}

BrdU detection is possible after APase-Fast Red-based ICC and fluorescence ISH with the MAb IIB5. BrdU-labeled, methanol-acetone-fixed EPLC 65 cells were first immunostained for either cytokeratin filaments or Ki67-Ag with the APase-Fast Red reaction. After fluorescence ISH with the FITC-labeled probe for the centromere of chromosome 7, MAb IIB5 was applied and detected by subsequent application of BioHAM antibodies and AvAMCA. Figures 11-1L show the results of these combined procedures, which allow simultaneous fluorescence detection of three different parameters in the same cell. Trisomy for chromosome 7 was clearly demonstrated in the majority of EPLC 65 cells (Figures $1 \mathrm{I}$ and $1 \mathrm{~K}$ ). From a comparison of Figures 11 and 
1J, it appears as if the BrdU-labeled (S-phase) cells show lower levels of cytokeratin filaments. This is not an artefact of the procedure, since cells containing strongly positive cytokeratin filaments were detected which showed high BrdU incorporation (e.g., Figures II and 1J, top left-hand corner). The APase-Fast Red staining pattern for Ki67-Ag was consistent with our earlier observations (Verheijen et al., 1989), which showed Ki67-Ag to be located in the nucleoli of interphase cells (Figure $1 \mathrm{~K}$ ). It is obvious that $\mathrm{Ki67- \textrm {Ag }}$ is present in both S-phase and BrdU positive cells as well as in non S-phase cells (compare Figures $1 \mathrm{~K}$ and $1 \mathrm{~L}$ ).

In NCI-H82 cells, we were also able to utilize this combined ICC/ISH procedure for simultaneous detection of N-CAM, the human centromere 7 DNA targets, and incorporated BrdU (data not shown).

\section{DISCUSSION}

This report describes the application of the APase-Fast Red enzymatic reaction, resulting in a red fluorescent precipitate, in combined ICC/ISH procedures. Fine-tuning of the enzyme reaction time, by monitoring the reaction in the microscope, in combination with the use of polyvinyl alcohol to prevent diffusion of the reaction product, resulted in discretely localized ISH signals in metaphase chromosome spreads and in interphase nuclei, and in accurate protein localization in cultured tumor cells. Together with the fact that this procedure results in strong fluorescent signals, the advantageous slow-fading properties of the precipitate make the APase-Fast Red reaction highly suitable for sensitive, high-resolution enzyme cytochemistry for fluorescence microscopy. The sensitivity of the procedure was demonstrated in resolving the cosmid probe on both chromatids of chromosome 11 (Figure 1B), the cytokeratin filaments in EPLC 65 cells (Figures $1 \mathrm{C}$ and $1 \mathrm{H}$ ), and titin banding in striated heart muscle. TO appeared to be a valuable DNA staining reagent in combination with APase-Fast Red fluorescence, although TO fluorescence was detected to a low extent through the red fluorescence filter set. Therefore, derivatives of TO are now being investigated for their better fluorescent properties in this respect. Use of the APase-Fast Red reaction for ICC proved to be very suitable in combination with ISH, since the precipitated reaction product was stable on pepsin pre-treatment at $\mathrm{pH} 2$ and throughout the entire ISH procedure.

The ISH results on APase-Fast Red immunostained lung cancer cells showed the correct number of ISH signals/nucleus compared with the non-immunostained cells (see Table 1). In colon adenoma cells displaying trisomy for the centromeric region of chromosome 7 , we utilized the combined ICC/ISH procedure to demonstrate the epithelial origin of the cells with the numerical chromosome aberration for chromosome 7 (Herbergs et al., 1994). From this, we conclude that the APase-Fast Red reaction product does not make the cells less accessible to ISH reagents and does not shield the target DNA. The latter phenomenon has been shown to occur when the peroxidase-diaminobenzidine reaction is used for the ICC step (Van den Brink et al., 1990; Strehl and Ambros, 1993). Application of the APase-Fast Red reaction has the advantage that directly FITC-labeled, centromere-specific DNA probes can thus be detected without any amplification step 
(Figures 1G-I and 1K), which increases analytical speed and reduces background reactions. Only when AMCA was used as the third fluorochrome were amplification steps needed, since in our hands the blue fluorescence intensity was less than the FITC or Fast Red fluorescence intensity (Figure $1 \mathrm{H}$ ).

The combined ICC/ISH procedure could be extended with the detection of incorporated $\mathrm{BrdU}$, since the heat denaturation step at $70^{\circ} \mathrm{C}$ applied in the ISH procedure is also suitable for subsequent BrdU detection with the anti-BrdU antibody. Therefore, three cell parameters can now be analyzed simultaneously in the same cell, using APase-Fast Red for antigen staining, FITC for visualization of a DNA probe, and AMCA for BrdU detection.

The accurate detection of these parameters in the same cell makes this procedure extremely suitable for detection of tumor cell heterogeneity, rare event detection, and in cases where only a few cells can be obtained for analysis (e.g., in aspirate cytology or in biopsy material). Furthermore, in cases where extensive proteolytic digestion for fluorescence ISH is needed (e.g., in paraffin sections that show autofluorescence induced by tissue fixation), ICC based on APase-Fast Red can be advantageous, since enzymatic digestion reduces autofluorescence but not the stable APase-Fast Red signal.

\section{Acknowledgements}

We thank Dr I Askad (Dako) for the rabbit anti-Ki67-Ag antiserum, Dr EB Lane (University of Dundee, Dundee, UK) for MAb anti-lamin B2, Dr D van Bockstalele (University of Antwerpen, Antwerpen, Belgium) for the DNA stain Thiazole Orange, and Dr B Schutte, $M$ Henfling, and $J$ Derhaag for technical assistence. This work was supported by the Netherlands Organization for Scientific Research NWO, grant no. 900-534-102.

\section{REFERENCES}

Balazs M, Mayall BH, Waldman FM (1991) Simultaneous analysis of chromosomal aneusomy and 5 bromodeoxyuridine incorporation in MCF-7 breast tumor cell line. Cancer Genet Cytogener 57:93-102

Boerman OC, Mijnheere EP, Broers JLV, Vooijs GP, Ramaekers FCS (1991) Biodistribution of a monoclonal antibody (RNL-1) against the neural cell adhesion molecule (NCAM) in athymic mice bearing human small-cell lung-cancer xenografts. Int J Cancer 48:457-462

Broers JLV, Klein Rot M, Oostendorp T, Bepler G, De Leij L, Carney DN, Vooijs GP, Ramaekers FCS (1988) Spontaneous changes in intermediate filament protein expression patterns in lung cancer cell lines. J Cell Sci $91: 91-108$

Buben(k J, Baresova M, Viklicky V, Jakoubkowa J, Sainerovd H, Donner J (1973) Established cell line of urinary bladder carcinoma (T24) containing tumour-specific antigen. Int J Cancer 11:765-773

Cooke HJ, Hindley J (1979) Cloning of human satellite III DNA: different components are on different chromosomes. Nucleic Acids Res 6:3177-3197

Dirks RW, Van de Rijke FM, Fujishita S, Van der Ploeg M, Ralap AK (1993) Methodologies for specific intron and exon RNA localization in cultured cells by haptenized and fluorochromized probes. J Cell Sci $104: 1187-1197$ 
Gendelman HE, Moench TR, Narayan O, Griffin DE, Clements JE (1985) A double labeling technique for performing immunocytochemistry and in sinu hybridization in virus infected cell cultures and tissues. J Virol Methods 11:93-103

Herbergs J, De Bruïne AP, Marx PTJ, Vallinga MU, Stockbrügger RW, Ramaekers FCS, Arends JW, Hopman AHN (1994) Chromosome aberrations in adenomas of the colon. Proof of trisomy 7 in tumor cells by combined interphase cytogenetics and immunocytochernistry. Int $\int$ Cancer $57,781.785$

Kiyama H, Emson PC (1991) An in situ hybridization histochemistry method for the use of alkalirve phosphatase-labeled oligonucleotide probes in small intestine. J Histochem Cytochem 39:1377-1384

Larsson L-I, Hougaard DM (1991) Combined non-radioactive detection of peptide hormones and their mRNA's in endocrine cells. Histochemistry 96:375-380

Losada AP, Wessman M, Tilainen M, Hopman AHN, Willard HF, Sole F, Rosa Caballin M. Woessner $S$, Knuutila S (1991) Trisomy 12 in chronic lymphocytic leukemia: an interphase cytogenetic study. Blood 78:775-779

Mullink H, Wallboomers JMM, Tadema TM, Jansen DJ, Meijer CILM (1989) Combined immuno- and non-radioactive hybridocytochemistry on cells and tissue sections: influence of fixation, enzyme pretreatment, and choice of chromogen on detection of antigen and DNA sequences... I Histochen Cytochem $37: 603-609$

Porten HJ, Heryet A, Quantrill AM, Fleming KA (1990) Combined non-isotopic in situ hybridization and immunohistochemistry on routine paraffin wax embedded tissue: identification of cell type infected by human parvovirus and demonstration of cytomegalovirus DNA and antigen in renal infection. I Clin Pathol 43:129-132

Ramaekers FCS, Puts JJG, Moesker O, Kant A, Huysmans A, Haag D, Jap PHK, Herman CJ, Vooijs GP (1983) Antibodies to intermediate filament proteins in the immunohistochemical identification of hamman tumours: an overview. Histochem J 15:691-713

Schutte B, Reynders MMJ, Bosman FT, Blijham GH (1987) Studies with anti-bromodeoxyuridine antibodies: II. Simultaneous immunocytochemical detection of antigen expression and DNA synthesis by in vivo labeling of mouse intestinal mucosa. J Histochem Cytochem 35:371-374

Speel ENM, Schutte B, Ramaekers FCS, Hopman AHN (1992a) The effect of avidin-biotin interactions. in detection systems for in situ hybridization. J Histochem Cytochem 40:135-141

Speel EIM, Schutte B, Wiegant J, Ramaekers FCS, Hopman AHN (1992b) A novel fluorescence detection method for in situ hybridization, based on the alkaline phosphatase-fast red reaction. J Histochem Cytochem 40:1299-1308

Speel EJM, Kamps M, Bonnet J, Ramaekers FCS, Hopman AHN (1993) Multicolour preparations for in situ hybridization using precipitating enzyme cytochemistry in combination with reflection contrast microscopy. Histochemistry 100:357-366

Strehl S, Ambros PF (1993) Fluorescence in situ hybridization combined with immunohistochemistry for highly sensitive detection of chromosome 1 aberrations in neuroblastoma. Cytogenet Cell Genet $63 \cdot 24-28$

Tokino $T$, Takahashi E, Mori M, Tanigami A, Glaser T, Park JW, Jones C, Hori T", Nakamura $Y$ (1991) Isolation and mapping of 62 new RFLP markers on human chromosome 11 . Am $J$ Hum Genet 48:258-268 
Trembleau $A$, Roche $D$, Calas $A$ (1993) Combination of non-radioactive and radioactive in sim hybridization with immunohistochentistry: a new method allowing the simultaneous detection of two mRNAs and one antigen in the same brain issue section. J Histochem Cytochem $41: 489-498$

Van Dekken H, Schervish EW, Pizzolo JG, Fair WR, Melamed MR (1991) Sinnultaneous detection of fluorescent in situ hybridization and in vivo incorporated BrdU in a human bladder tumour. $J$ Pathol $164: 17-22$

Van den Berg H, Vossen JM, Van den Bergh RL, Bayer J, Van Tol MJD (1991) Detection of $Y$ chromosome by in situ bybridization in combination with membrane antigens by two-color immunofluorescence. Lab Invest 64:623-628

Van den Brink W, Van der Loos C, Volkers H, Lauwen R, Van den Berg F, Houthoff H, Das PK (1990) Combined $\beta$-Galactosidase and immunogold/silver staining for immunohistochemistry and DNA in situ hybridization. J Histochem Cytochem 38:325-329

Van Noorden CJF, Vogels IMC (1989) Polyvinylalcohol and other tissue protectants in enzyme histochemistry: a consumer's guide. Histochem J 21:373-379

Verheijen R, Kuijpers HJH, Schlingemann RO, Boehmer ALM, Van Driel R, Brakenhoff GJ, Ramaekers FCS (1989) Ki-67 detects a nuclear matrix-associated proliferation antigen. I. Intracellular localization during interphase. J Cell Sci 92:123-130

Waye JS, Willard HF (1986) Molecular analysis of a deletion polymorphism in alpha satellite of human chromosome 17: evidence for homologous unequal crossing-over and subsequent fixation. Nucleic Acids Res 14:6915-6928

Waye JS, England SB, Willard HF (1987) Genomic organization of alpha satellite DNA on human chromosome 7: evidence for two distinct alphoid domains on a single chromosome. Mol Cell Biol 7:349356

Weber-Matthiesen K, Deerberg J, Müller-Hermelink A, Schlegelberger B, Grote W (1993) Rapid immunophenotypic characterization of chromosomally aberrant cells by the new fiction method. Cytogenet Cell Genet 63:123-125

Wolfson B, Manning RW, Davis LG, Arentzen R, Baldino F Jr (1985) Co-localization of corticotropin releasing factor and vasopressin $m R N A$ in neurones after adrenalectomy. Nature 315:59-61 


\title{
CHAPTER 7
}

\section{MULTI-PRINS: MULTTPLE SEQUENTIAL OLIGONUCLEOTIDE PRIMED IN SITU DNA SYNTHESIS REACTIONS LABEL SPECIFIC CHROMOSOMES AND PRODUCE BANDS}

\author{
Ernst JM Speel, Diane Lawson, Anton HN Hopman, John Gosden
}

Hum Genet 95, 29-33, 1995

\section{ABSTRACT}

A fast method for identifying several chromosomes with chromosome-specific oligonucleotide primers directing an in situ labeling reaction is described. Up to three reactions distinguished by different fluorochromes (fluorescein isothiocyanate (FITC), rhodamin/Texas Red, amino methyl coumarin acetic acid (AMCA)) can currently be performed. Prospects for increasing this up to seven colors, and for the future of the process in prenatal diagnosis are discussed. 


\section{INTRODUCTION}

The primed in situ (PRINS) DNA synthesis reaction (Koch et al., 1989) has been steadily improved in both sensitivity and versatility (Gosden et al., 1991; Gosden and Hanratty, 1993; Gosden and Lawson, 1994; Hindkjar et al., 1994). In the present report, we describe a further step in this improvement, by means of multiple sequential oligonucleotide primed reactions to label different specific target chromosomal DNA sequences with different colors (green, red, blue). This represents a clinically significant development, with the combination of the speed of the PRINS process and the multi-target potential of fluorescence in situ hybridization (ISH) (Nederlof et al., 1990; Ried et al., 1992).

\section{MATERIALS AND METHODS}

\section{Preparation of metaphase spreads}

Metaphase chromosomes were prepared from peripheral blood lymphocytes by standard methods and suspensions were stored in methanol:acetic acid $(3: 1 \mathrm{v} / \mathrm{v})$ at $-20^{\circ} \mathrm{C}$ until required for slide preparation. Slides were used within a week of preparation. For optimal results, one-day-old slides were passed through an allcohol series $(70 \%, 90 \%$, and $100 \%)$, which helped in preserving chromosome morphology, and air-dried before the first PRINS reaction.

\section{Oligonucleotide primers}

All oligonucleotide primers were synthesized on an Applied Biosystems Model 381A according to the manufacturer's instructions. Details are given in Table 1 .

Table 1. Sequences of oligonucleotide primers.

\begin{tabular}{lll} 
Nane & Origin & Sequence \\
\hline $450(19-$ mer) & Alu, 5' end of consensus & AAAGTGCTGGGATTACAGG \\
D599(27-mer) & DYZ1 & TGGGCTGGAATGGAAAGGAATCGAAAC \\
D600 (27-mer) & DYZ1, pair for D599 & TCCATTCGATTCCATTTTTTTCGAGAA \\
E528 (20-mer) & D7Z1, + strand & AGCGATTTGAGGACAATTGC \\
E563 (23-mer) & DXZ1, + strand & ATAATTTCCCATAACTAAACACA \\
E564 (23-mer) & DXZ1, - strand & TGTGAAGATAAAGGAAAAGGCTT \\
G33 (19-mer) & D9Z1, & AATCAACCCGAGTGCAATC \\
G35 (19-mer) & D11Z1 & GAGGGTTTCAGAGCTGCTC \\
\hline
\end{tabular}

Except for primer 450 , all primer sequences are derived from centromeric repetitive seguences of chromosomes $Y, 7, X, 9$, and 11 , respectively.

\section{PRINS}

The details of the PRINS process have been described previously (Gosden and Hanratty, 1993; Gosden and Lawson, 1994). Briefly, for most reactions, chromosomal DNA was denatured by incubation in $70 \%$ formamide, $2 \times S S C(0.3 \mathrm{M}$ 
$\mathrm{NaCl}, 30 \mathrm{mM}$ Na-citrate), $\mathrm{pH} 5.0$, at $70^{\circ} \mathrm{C}$ for $2 \mathrm{~min}$, followed by passage through an alcohol series (with the $70 \%$ ethanol at $4{ }^{\circ} \mathrm{C}$ ), and air-drying. The $50 \mu \mathrm{ll}$ reaction mix of Taq buffer, consisting of $50 \mathrm{mM} \mathrm{KCl}, 10 \mathrm{mM}$ Tris- $\mathrm{HCl}$, pH $8.3,1.5 \mathrm{mM}$ $\mathrm{MgCl}_{2}, 0.01 \%$ bovine serum albumin (BSA), contained $0.2 \mathrm{mM}$ dATP, dGTP, dCTP, $0.02 \mathrm{mM}$ dTTP, $0.02 \mathrm{mM}$ of one of biotin-16-dUTP (Boehringer, Mannheim, Germany), digoxigenin-11-dUTP (Boehringer), or FluoroRed- or FluoroGreen-dUTP (Amersham, Little Chalfont, U.K.) with 50-250 ng of one primer or primer pair, and 1 U Taq polymerase (Perkin Elmer, Chalfont St. Giles, U.K., or Boelhringer). An aliquot of $40 \mu \mathrm{l}$ of this solution was placed on an acid/alcohol cleaned coverslip, which was picked up with a denatured slide and sealed with rubber solution. The rubber solution was allowed to dry before transferring the slide to the flat bed of a HYBAID OmniGene or OmniSlide thermal cycler. For most primers, incorporation of fluorochrome-labeled dUTP (FluoroRed or FluoroGreen) produced adequate signals, but for lower copy number targets, incorporation of biotin-16-dUTP or digoxigenin-11-dUTP resulted in stronger signals after fluorescence detection (see below).

The first PRINS reaction cycle consisted of $5 \mathrm{~min}$ at the annealing temperature for the oligonucleotide $\left(45-60^{\circ} \mathrm{C}\right.$ ), followed by $5-10 \mathrm{~min}$ at $70^{\circ} \mathrm{C}$. The reaction was stopped by transferring the slides (after removal of the rubber solution seal) to $50 \mathrm{ml}$ of 0.5 $\mathrm{M} \mathrm{NaCl}, 50 \mathrm{mM}$ EDTA in a Coplin jar at $60^{\circ} \mathrm{C}$ for $1 \mathrm{~min}$. For the sequential reactions reported here, it was found necessary to incubate the slides, after the first PRINS reaction, with $0.025 \mathrm{mM}$ dideoxynucleotide triphosphates (ddNTPs) in $40 \mu 1$ $0.05 \mathrm{M}$ Tris- $\mathrm{HCl}, \mathrm{pH} 7.2,0.01 \mathrm{M} \mathrm{MgSO}_{4}, 0.01 \mathrm{mM}$ dithiothreitol, $0.15 \mathrm{mg} / \mathrm{ml} \mathrm{BSA}$ with $1 \mathrm{U}$ Klenow DNA polymerase under a coverslip for $1 \mathrm{hr}$ at $37^{\circ} \mathrm{C}$ in order to prevent free 3' ends of the newly synthesized DNA being used as primers for subsequent reactions. Following this step, the slides were passed through an ethanol series $(70 \%, 90 \%$, and $100 \%)$ and air-dried before repeating the PRINS (omitting any denaturation step) with a second primer and different reporter.

For some reactions, it was possible to use the instant PRINS process (Gosden and Lawson, 1995) in which the slide is denatured as part of the thermal cycle, with the reaction mix, including a fluorochrome-dUTP, in place; a brief cycle, with 1 min denaturation, $1 \mathrm{~min}$ annealing, and $5 \mathrm{~min}$ extension was used. The reaction was stopped and free $3^{*}$ ends blocked as described above; subsequent PRINS reactions omitted the denaturation step.

\section{Cytochemical detection}

After the final PRINS cycle, the reaction was stopped as described above, and was followed by incubation of the slides in blocking buffer (4xSSC, $0.05 \%$ Triton X-100, $5 \%$ non-fat dry milk) at room temperature for $5 \mathrm{~min}$. Detection of hapten-dUTPs (biotin or digoxigenin) was performed as described previously (Gosden and Lawson, 1994). Biotin-16-dUTP was detected with fluorescein isothiocyanate (FITC)conjugated avidin, Texas Red-conjugated avidin, or two layers of amino methyl coumarin acetic acid (AMCA)-conjugated avidin, linked by a layer of biotinylated goat anti-avidin (all from Vector, Brunschwig Chemie, Amsterdam, The Netherlands) 


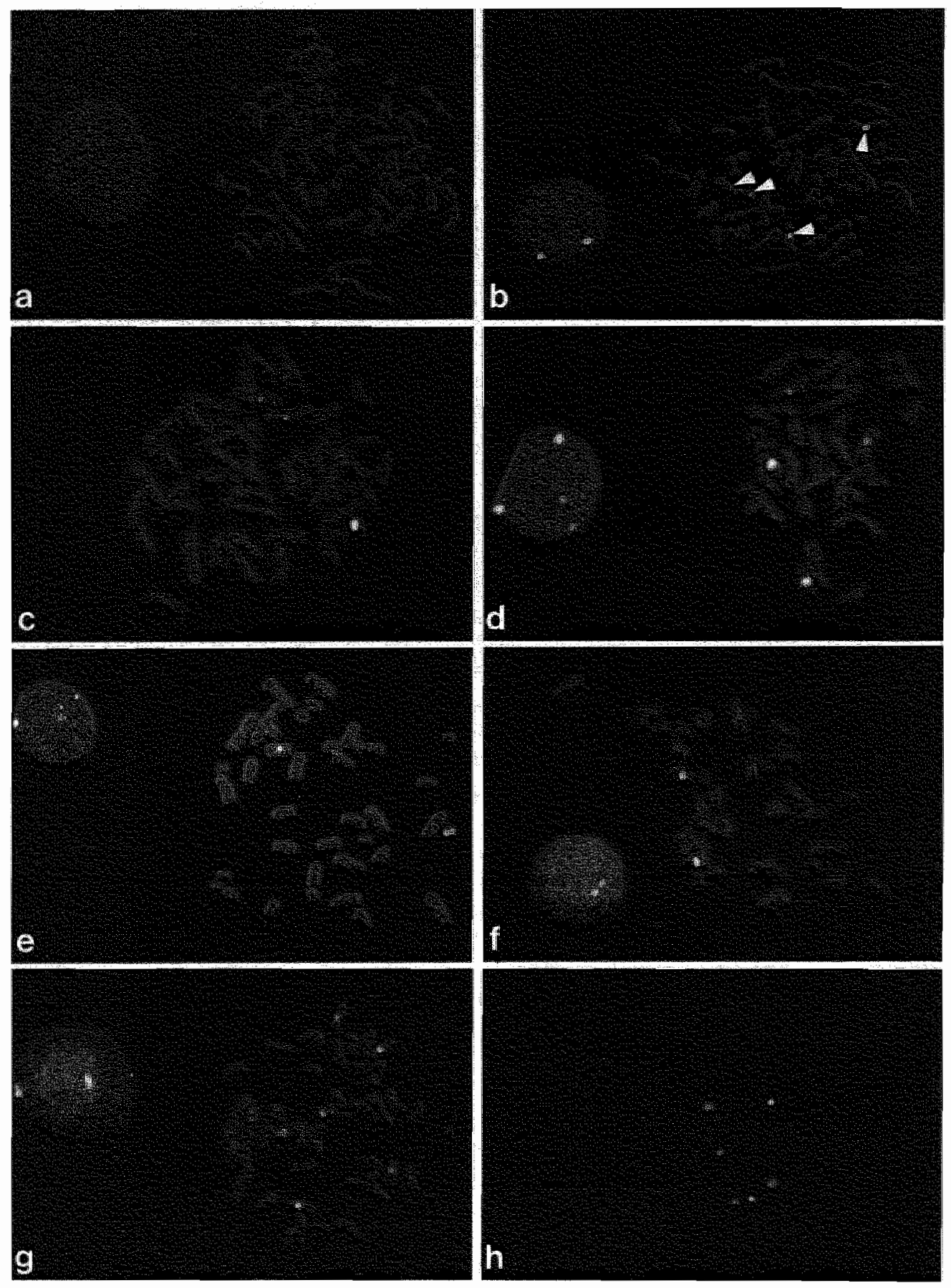


Figure 1. PRINS. Except where stated, all primers were annealed at $60^{\circ} \mathrm{C}$. (a) Alu primer (450) labeled with FluoroRed, produces R-banding. (b) Alu primer labaled with FiuotoRed, and chromosome 9 primer $\left(\mathrm{G} 33\right.$, annealed at $\left.55^{\circ} \mathrm{C}\right)$ labeled with biotin/FITC. Arrowheads at 2 o'clock and 6 o"clock: chromosome 9 centromeric label; arrowheads left: residual Alw label on chromosome 19. (c) Chromosome 7 primer (E528) labelled with biotin/Texas Red, Y chromosome (D599+D600) labeled with digoxigenin/FITC, counterstained with DAPI. (d) Chromosome 7 primer (E528) labeled with biotin/Texas Red, chromosome 9 primer (G33, as in b), counterstained with DAPI. (e) Instant PRINS, $X$ chromosome (ES63/E564, annealed at $45^{\circ} \mathrm{C}$ ) labeled with FluoroGrean, $Y$ chromosome (as in c) labeled with FluoroRed, counterstained with DAPI. (f) As e, but labels reversed, i.e. $\mathrm{X}$ labeled with FluoroRed, $Y$ with FluoroGreen by instant PRINS. (gi) Chromosome 9 labeled with biotin/AMCA (blue), chromosome 7 labeled with digoxigenin/FITC (green), and Alu labeled with FluoroRed. (h) Chromosome 9 labeled with biotin/AMCA, chromosome 7 labeled with FluoroRed, and chromosome 11 (G35) labeled with digoxigenin/FITC. Magnification: 1000x.

whereas digoxigenin-11-dUTP was visualized by FITC- or rhodamin-conjugated sheep anti-digoxigenin IgG (Boehringer). Slides on which centromeres were labelled with red and green fluorochromes were counterstained with 4,6-diamino-2-phenyl indole (DAPI; Sigma, St. Louis, MO, USA). In others, a primer for the Alu sequence was used to produce an R-band pattern, and in some, where three sets of centromeres were differentially stained, no counterstain was possible. All slides were examined under a Leitz Ortholux II microscope equipped with the appropriate Ploemopak filters for these fluorochromes. For single PRINS and double PRINS with Alu banding (Figures 1A and 1B), selected cells were scanned with the BioRad MRC 600 confocal scanning laser system attached to the same microscope, the images being stored on an IBM 3360 optical disk. Results of other multi-PRINS experiments (Figures $1 \mathrm{C}-\mathrm{H}$ ) were evaluated on a Zeiss Axioplan microscope equipped with a Chroma Technology triple band pass filter (DAPI:FITC:Texas Red) and a Photometrics charge-coupled device (CCD) camera controlled by a Macintosh Quadra.

\section{RESULTS}

The initial experiments used a primer from the Alu sequence in conjunction with a chromosome-specific alphoid satellite primer. A typical result for the Alu primer alone is shown in Figure 1a. In Figure $1 \mathrm{~b}$, the chromosomes are R-banded with the Alu primer labeled with FluoroRed, and the chromosomes 9 are labeled with FITC in both the metaphase and an interphase nucleus (see 'Discussion'). Experiments with two sets of chromosome-specific primers are shown in the next four frames. The chromosomes are counterstained with DAPI. Figure 1c shows primers from D7Z1 and DYZ1, labeled with Texas Red and FITC, respectively. Figure $\mathbb{1 d}$ shows the same primer from chromosome 7 , in this case in combination with a primer from chromosome 9. The $\mathrm{X}$ and $\mathrm{Y}$ chromosomes in male cells, labeled by instant PRINS (Gosden and Lawson, 1995), are shown in Figures le and 1f. It made no difference which primed sequence was labeled with which reporter, although the ratio of labeled 
Table 2. Number of chromosomes labeled (percent) in 20 metaphase and 20 interphase cells with double PRINS for $X$ and $Y, 7$ and $Y$, and 7 and 9 .

\begin{tabular}{lllll}
\hline Primers & \multicolumn{2}{c}{ Metaphase } & \multicolumn{2}{c}{ Interphase } \\
\hline$X$ and $Y$ & $X$ & $Y$ & $X$ & $Y$ \\
& $17(85)$ & $20(100)$ & $18(90)$ & $20(100)$ \\
7 and $Y$ & 7 & $Y$ & 7 & $Y$ \\
& $40(100)$ & $20(100)$ & $40(100)$ & $20(100)$ \\
7 and 9 & 7 & 9 & 7 & 9 \\
& $36(90)$ & $38(95)$ & $38(95)$ & $38(95)$ \\
\hline
\end{tabular}

dUTP to unlabeled dTTP was important: for DXZ1, a ratio of 1:1 was needed, whereas for DYZ1 1:4 was adequate. In Figure 1e, the X chromosome is labeled with FluoroGreen, and the $\mathrm{Y}$ with FluoroRed, whereas in Figure If, the signals are reversed. For both the $\mathrm{X}$ and $\mathrm{Y}$ sequences, paired primers gave cleaner signals than either primer singly, whereas for most other chromosomes, a single primer produced a clean adequate signal (Gosden and Lawson, 1994). Figure $1 \mathrm{~g}$ shows two alphoid primed reactions (D9Z1 and D7Z1) combined with the Alu-primer induced R-banding. Figure 1 h shows the signals produced by three alphoid primers (D7Z1, $\mathrm{D} 9 \mathrm{Z1}$, and DIIZ1) without counterstain.

In order to estimate the reliability and consistency of the method, labeled chromosomes were counted in 20 metaphase and 20 interphase cells for three double PRINS experiments with chromosomes $X$ and $Y$, chromosomes $Y$ and 7 , and chromosomes 7 and 9 , respectively. The counts were made on a standard Leitz Ortholux II microscope fitted with Ploemopak filters, to demonstrate that no further sophisticated equipment is required. The results (shown in Table 2) confirm, that the system, as well as being quicker to perform, gives at least as good an analysis as that obtained with conventional ISH, with between $85 \%$ (for the $\mathrm{X}$ chromosome) and $100 \%$ (for chromosomes 7 and $\mathrm{Y}$ ) of both metaphase and interphase cells having all the specific chromosomes labeled.

\section{DISCUSSION}

The ability to detect multiple targets rapidly by sequential PRINS reactions is an important step forward in the development of this technique. The use of short oligonucleotides (19-27 mers), at concentrations of only 50-250 ng per slide, proved to be sufficient to produce intense, specific, and distinct staining of chromosomal DNA sequences. Furthermore, in order to preserve the chromosome morphology, a short denaturation step of $2 \mathrm{~min}$ at $70^{\circ} \mathrm{C}$ in $70 \%$ formamide, $2 \times S S C$ (or $30 \mathrm{sec}-1 \mathrm{~min}$ at $95^{\circ} \mathrm{C}$ on the flat bed of the HYBAID OmniGene thermal cycler for instant PRINS), prior to the annealing step, followed by as short an extension stage at $70^{\circ} \mathrm{C}$ as 
possible (as little as $1 \mathrm{~min}$ can be sufficient (Gosden and Lawson, 1995)) is preferable to denaturation for $5 \mathrm{~min}$ at $94^{\circ} \mathrm{C}$ and prolonged extension (up to $30 \mathrm{~min}$ ) as

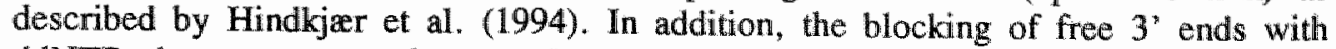
ddNTPs between successive PRINS reactions can be performed at $37^{\circ} \mathrm{C}$ with the Klenow DNA polymerase, and is more efficient and accurate than using Taq polymerase at higher temperatures. The procedure described here produces high signal intensities combined with good preservation of chromosome morphology.

Although the primer oligonucleotides used in the sequential reactions may differ in their optimal annealing temperature, this does not affect the outcome of the reaction, as the labeled product produced in situ has much greater thermal stability than the oligonucleotides, and is retained even at high temperatures. This is to be expected from our results with cycling PRINS, in which several cycles of denaturation, annealing, and extension are performed with the same primer/s and lead to amplification of the signal in situ without loss or diffusion of the product (Gosden and Hanratty, 1993). There is, however, at least one critical point. Where one primer or set of primers gave a stronger signal than the other, it was found preferable to perform the PRINS with the primer/s giving the stronger signal first (e.g., D599 and D600, the $Y$ primers in the case of the X and $Y$ double PRINS; Figures le and If). It is also relevant here to consider the efficiency of the reaction to block free 3 ' ends generated by earlier PRINS reactions. In most cases, this is complete, but in the case of the Alu primer, there are so many sites on chromosome 19 (the most Alu-rich chromosome) that not all the ends may be blocked by dideoxynucleotides. An example is seen in Figure 1b, where in addition to the two large labeled sites on chromosome 9, there is a small spot on the long arm of each chromosome 19, where the second label (FITC) was incorporated.

Although using one reaction to produce R-bands limits the colors available for other labels, this still means that two pairs of normal chromosomes can be identified by both centromere label and banding pattern, and any marker chromosome be identified at least by centromere. These are significant developments, both for prenatal diagnosis (for chromosomal sex or the identification or elimination of aneuploidy) and for the analysis of the human chromosomal component of hybrid cell lines. Where it is necessary to identify more than two kinds of chromosomes simultaneously, in the present state of the art, this can only be done in the absence of chromosome bands (Figure 1h). However, the development of a sensitive triple-color ISH protocol for brightfield microscopy may be relevant here, as the chromosomes can be counterstained with hematoxylin (Speel et al., 1994). We are currently evaluating this procedure for use in multi-PRINS.

In addition, different fluorescence strategies can be followed to increase further the adaptability of the PRINS technique, e.g., by the use of new fluorochromes such as Cy5 (Molecular Probes, Eugene, OR, USA), which can be detected in the far red by confocal microscopes and CCD cameras using an appropriate filter set, or by combinatorial labeling of chromosomal target DNA sequences with two or more reporters in different ratios, followed by CCD imaging (Nederlof et al., 1990; Ried et al., 1992). 
Although the figures for this report were produced on a confocal microscope (Figures 1a and 1 b) or a CCD camera (Figures $1 \mathrm{c}$-h), this equipment is not necessary for adequate analysis. The efficacy of a conventional fluorescence microscope for anallysis is confirmed in the "Results" and Table 2.

\section{Acknowledgements}

We should like to thank HU Weier for the sequences of the D9Z1, D11Z1, and DYZ1 primers, P Warburton for the sequences of the D7Z1 and DXZ1 primers, A Gallacher for making all the primers, and N Davidson, S Bruce, and D Stuart for preparation of the figure. This work was supported by the Netherlands Organization for Scientific Research NWO, grant no, 900-534-102, a short-term fellowship from the Federation of European Biochemical Societies (FEBS), and the Human Genome Mapping Programme of the UK Medical Research Council, grant no. E321/118, which provided the confocal scanning laser system.

\section{REFERENCES}

Gosden $J_{x}$ Hanratty D, Starling $I_{\text {, Fantes }} J$, Mitchell A, Porteous D (1991) Oligonucleotide primed in situ DNA synthesis (PRINS): a method for chromosome mapping, banding and investigation of sequence organization. Cytogenet Cell Genet 57:100-104

Gosden J, Hanratty D (1993) PCR In Situ (PCR -IS), a rapid alternative to in situ hybridization for mapping short, low copy number sequences without isotopes. BioTechniques 15:78-80

Gosden J, Lawson D (1994) Rapid chromosome identification by oligonucleotide-primed in situ DNA synthesis (PRINS). Hum Mol Gener 3:931-936

Gosden J, Lawson D (1995) Instant PRINS: a rapid method for chromosome identification by detecting repeated sequences in situ. Cytogenet Cell Genet 68:57-60

Hindkjar J, Koch J, Terkelsen C, Brandt CA, Kolvraa S, Bolund L (1994) Fast, sensitive multicolor detection of nucleic acids in situ by primed in situ labelling (PRINS). Cytogenet Cell Genet $66: 152-154$

Koch JE, Kalwraa S, Petersen KB, Gregersen N, Bolund L (1989) Oligonucleotide-priming methods for the chromosome-specitic labelling of alpha satellite DNA in situ. Chromosoma 98:259-265

Nederlof PM, Van der Flier S, Wiegant J, Raap AK, Tanke HJ, Ploem JS, Van der Ploeg M (1990) Multiple fluorescence in situ hybridization. Cytometry 11:126-131

Ried T, Baldini A, Rand TC, Ward DC (1992) Simultaneous visualization of seven different DNA probes by in situ hybridization using combinatorial fluorescence and digital imaging microscopy. Proc Natl Acad Sci USA 89:1388-1392

Speel EJM, Jansen MPHM, Ramaekers FCS, Hopman AHN (1994) A novel triple-color detection procedure for brightfield microscopy, combining in situ hybridization with immunocytochemistry. IJ Histochem Cytochem 42:1299-1307 


\title{
CHAPTER 8
}

\section{RAPTD DETECTION OF OLIGONUCLEOTIDE PRIMED IN SITU (PRINS) LABELED DNA IN METAPHASE PREPARATIONS, TISSUE SECTIONS, AND IMMUNOSTAINED CELLS}

\author{
Ernst JM Speel, Diane Lawson, Frans CS Ramaekers, John Gosden, \\ Anton HN Hopman
}

\begin{abstract}
We describe an improved method for rapid detection of repeated DNA sequences in cell preparations and frozen tissue sections using chromosome-specific oligonucleotide primers in a primed in situ (PRINS) labeling reaction. Up to three different target sequences could be localized simultaneously in hematoxylin counterstained metaphases and interphase nuclei following application of a triple-color brightfield detection method. In addition, new protocols are reported for the application of PRINS to tissue sections and immunostained cell cultures. Although it proved to be essential to subject these preparations to proteolytic digestion before performing the PRINS reaction, the morphology of the nuclei, cells, and tissue could be preserved to a great extent, making the described procedures valuable tools for application in molecular cytogenetics, cell biology, and pathology.
\end{abstract}




\section{INTRODUCTION}

Primed in situ (PRINS) labeling has become an alternative to in situ hybridization (ISH) for the localization of nucleic acid sequences in cells and tissues. The procedure is based on the rapid annealing of an unlabeled DNA primer (restriction fragment, PCR product; or oligonucleotide) to its complementary target sequence in situ. The primer serves as an initiation site for in situ chain elongation using a DNA polymerase and labeled nucleotides, which can be detected directly by fluorescence microscopy, such as fluorochrome-labeled dNTPs, or indirectly using, e.g., biotin- or digoxigenin-dUTP and the application of fluorochrome-conjugated avidin or antibody molecules (Gosden and Lawson, 1994, 1995; Hindkjaer et al., 1994). Since its introduction (Koch et al., 1989), the PRINS technique has been improved considerably for detection of specific RNA and DNA sequences in cell preparations (Mogensen et al., 1991; Bains et al., 1993; Gosden and Lawson, 1994). The detection limit of the PRINS technique appears to be in the order of low copy sequences (Abbo et al., 1993; Gosden and Lawson, 1994).

Recently, the detection of multiple DNA targets using different fluorochromes in sequential PRINS reactions has been reported (Gosden and Lawson, 1994; Hindkjaer et al., 1994; Speel et al., 1995). For the simultaneous identification of more than two DNA sequences, however, DNA counterstaining or chromosome banding is in principle not possible, since the available fluorescence colors are utilized for specific target detection. In the present report, we describe the application of a recently developed triple-color brightfield procedure for the detection of PRINS-labeled nucleic acid sequences, so that also chromosomes and nuclei can be visualized with hematoxylin counterstaining (Speel et al., 1994b). Moreover, since a brightfield approach does not require a fluorescence microscope with a confocal set up or CCD camera for image analysis and processing, and has the advantage that no fading of the PRINS signals occurs, as they are permanently localized and can be examined in relation to cell morphology, this approach is to be preferred for routine application and diagnostic purposes (Speel et al., 1994b; Troyer et al., 1994).

An additional interesting development comprises the utilization of the PRINS technique on frozen tissue sections, which is reported here using both a brightfield and a fluorescence approach. In this way, individual cells can be identified within their tissue context and be analyzed on basis of their copy numbers of investigated chromosome regions. This application can be of particular importance in the area of tumor pathology.

Finally, we demonstrate that the PRINS technique can be combined with immunocytochemistry (ICC), providing a procedure for the simultaneous demonstration of a protein and a DNA target sequence in the same cell. The usefulness of the alkaline phosphatase (APase)-Fast Red reaction for ICC in such a combined procedure has previously been reported (Speel et al., 1994a). A combined ICC/PRINS method may be advantageous in cases, where the rapid immunophenotyping of cells containing a specific chromosome content or viral infection is required. 


\section{MATERIALS AND METHODS}

\section{Preparation of metaphase spreads and tissue sections for PRINS}

Chromosomes were prepared from peripheral blood lymphocytes by standard methods, fixed in methanol:acetic acid $(3: 1 \mathrm{v} / \mathrm{v})$, and spread on acid/alcohol cleaned slides. Slides were used within a week of preparation, whereas the cell suspension could be stored at $-20^{\circ} \mathrm{C}$ for up to three months. Slides were passed through an alcohol series $(70 \%, 96 \%$, and $100 \%)$ which helped in preserving chromosome morphology, and air-dried before the first PRINS reaction.

Fresh tissue samples from normal colon and bladder epithelium were obtained after surgical resection and snap frozen in liquid nitrogen. Frozen sections of $4 \mu \mathrm{m}$ thickness were mounted on poly-L-lysine coated slides and stored at $-20^{\circ} \mathrm{C}$. Prior to use, slides were air-dried and fixed in methanol:acetic acid $(3: 1 \mathrm{v} / \mathrm{v})$ for $10 \mathrm{~min}$ at room temperature (RT). The slides were air-dried, washed for $5 \mathrm{~min}$ in phosphatebuffered saline (PBS; $0.15 \mathrm{M} \mathrm{NaCl}, 10 \mathrm{mM} \mathrm{Na}$-phosphate, pH 7.2) and 2 min in $0.01 \mathrm{~N} \mathrm{HCl}$, digested with $100 \mu \mathrm{g} / \mathrm{ml}$ pepsin in $0.01 \mathrm{~N} \mathrm{HCl}$ for $10 \mathrm{~min}$ at $37^{\circ} \mathrm{C}$, and passed through an alcohol series starting with $70 \%$ ethanol in $0.01 \mathrm{~N} \mathrm{HCl}$, which helped in preserving cell morphology. Tissue sections were post-fixed in $1 \%$ paraformaldehyde in PBS for 10 min at RT, washed in PBS for $5 \mathrm{~min}$, dehydrated, and subjected to the PRINS procedure.

\section{Preparation of cells for combined ICC/PRINS}

The hybrid cell lines $\mathrm{C} 121$-TN6, containing chromosome 7 as sole human component (from one to five copies per cell) on a mouse background, and J1-C14, containing human chromosome 11 on a Chinese hamster background, were grown on slides as described previously (Dorin et al., 1989; Glaser et al., 1989). The slides were washed twice in PBS for $5 \mathrm{~min}$, fixed by dipping in cold methanol $\left(-20^{\circ} \mathrm{C}\right)$ for $5 \mathrm{sec}$ and three times for $5 \mathrm{sec}$ in acetone $\left(4^{\circ} \mathrm{C}\right)$ as described before (Speel et al., 1994a), and stored at $-20^{\circ} \mathrm{C}$ until use.

\section{Immunostaining of cellular antigens and cell processing}

The following monoclonal antibodies (MAbs) were used: (a) undiluted culture supernatant of MAb EGFR1, directed against the epidermal growth factor (EGF) receptor on C121-TN6 cells (a kind gift from V van Heyningen, Edinburgh, U.K.), and (b) undiluted culture supernatant of MAb 163A5, directed against a cell-surface antigen on J1-C14 cells (Glaser et al., 1989). ICC using the APase-Fast Red reaction was performed as described previously (Speel et al., 1994a). Briefly, slides were incubated with MAbs for $30 \mathrm{~min}$ at $37^{\circ} \mathrm{C}$. After three washes of $3 \mathrm{~min}$ each in PBS containing $0.05 \%$ Triton $\mathrm{X}-100$ (Buffer $\mathrm{A}$ ), the MAbs were detected by incubation with APase-conjugated goat anti-mouse IgG (GAMAPase, diluted 1:25 in Buffer A containing $2 \%$ normal goat serum) (Dako, Glostup, Denmark) for 30 min at $37^{\circ} \mathrm{C}$. After three washes of 3 min each in PBS, the APase-Fast Red staining reaction was performed as described earlier (Speel et al., 1994a). Thereafter, the cells were washed in $0.01 \mathrm{~N} \mathrm{HCl}$ for 2 min at $37^{\circ} \mathrm{C}$, digested with $100 \mu \mathrm{g} / \mathrm{ml}$ pepsin in $0.01 \mathrm{~N}$ 
Figure 1. PRWNS results on nomal human male lymphocyte metaphases $\left(a_{,}, c\right)$ and interphase nuclei $(b, d)$, frozen tissue sections of normal colon (e) and bladder $(f, g)$ epithelium, and immunostained C121-TN6 cells (h). Preparations were counterstained with hematoxylin (a-n) or DAPI (g). (a,b) Brightfield detection of chromosome 9 and 7 centromeres with biotin/PO-DAB (brown) and digoxigenin/APase-Fast Red (red), respectively; (c,d) Brightfield detection of chromosome 9, 7, and $Y$ centromeres with biotin/PO-DAB (brown), digoxigenin/APase-Fast Red (red), and fluorescein/POTMB (green), respectively; $(e, n)$ Brightfield detection of chromosome 9 centromeres with biotin/POTME (green) (e), and biotin/PO-DAB (f); (g) Fluorescence detection of chromosome 9 centromeres with Fluorored (red); (h) Simultaneous fluorescence detection of EGF receptor with APase-Fast Red (red) and four chromosome 7 centromeres with biotin/FITC (green). Magnifications: $(\mathrm{a}-\mathrm{f}), 900 \mathrm{x}$; $(\mathrm{g})$, $675 x ;(h), 1250 x$.

$\mathrm{HCl}$ for $20 \mathrm{~min}$ at $37^{\circ} \mathrm{C}$, washed again in $0.01 \mathrm{~N} \mathrm{HCl}$ for $2 \mathrm{~min}$, dehydrated, and post-fixed with $1 \%$ paraformaldehyde in PBS for $20 \mathrm{~min}$ at $4^{\circ} \mathrm{C}$. Cells were then subjected to the PRINS procedure (see below).

\section{Oligonucleotide primers}

The oligonucleotides used in this study included primers specific for the centromeric regions of human chromosome 7 (20-mer, AGCGATTTGAGGACAATTGC), chromosome 9 (19-mer, AATCAACCCGAGTGCAATC), chromosome 11 (19-mer, GAGGGTTTCAGAGCTGCTC), and the Y chromosome (27-mer, TCCATTCGATTCCATTTTTTTCGAGAA) (Speel et al., 1995). All primers were synthesized on an Applied Biosystems Model 381A DNA synthesizer according to the manufacturer's instructions.

\section{PRINS}

PRINS reactions on metaphase preparations have been described previously (Gosden and Lawson, 1994; Speel et al., 1995). Briefly, chromosomal DNA was denatured in $70 \%$ formamide, $2 \times S S C(0.3 \mathrm{M} \mathrm{NaCl}, 30 \mathrm{mM} \mathrm{Na}$-citrate), pH 5.0 , for $2 \mathrm{~min}$ at $70^{\circ} \mathrm{C}$, followed by dehydration with $70 \%$ ethanol at $4^{\circ} \mathrm{C}, 90 \%$, and $100 \%$ ethanol, and air-drying. The reaction mix contained $0.2 \mathrm{mM}$ dATP, dGTP, dCTP; $0.02 \mathrm{mM}$ dTTP; $0.02 \mathrm{mM}$ biotin-16-dUTP, digoxigenin-11-dUTP, fluorescein-12-dUTP (Boehringer, Mannheim, Germany), or FluoroRed-dUTP (Amersham, Little Chalfont, U.K.); 250 ng of primer; and 1 U Taq polymerase (Perkin Elmer, Chalfont St. Giles, U.K., or Boehringer) in $50 \mu l$ Taq buffer $(50 \mathrm{mM} \mathrm{KCl}, 1.5 \mathrm{mM} \mathrm{MgCl}, 0.01 \%$ bovine serum albumin (BSA)). Forty $\mu$ l of this mixture was placed under an acid/alcohol cleaned coverslip on the slides and sealed with rubber cement. Slides were transferred to a Hybaid Omnigene Flatbed thermal cycler. Each PRINS reaction cycle consisted of 5 min at $55^{\circ} \mathrm{C}$ (chromosome 9-specific primer) or $60^{\circ} \mathrm{C}$ (chromosome 7, 11, and $\mathrm{Y}$-specific primers) to anneal the primer to the chromosomal DNA, followed by $15 \mathrm{~min}$ at $70^{\circ} \mathrm{C}$ for chain elongation. The reaction was stopped by transferring the slides (after removal of rubber solution seal) to $50 \mathrm{ml}$ of $500 \mathrm{mM}$ $\mathrm{NaCl}, 50 \mathrm{mM}$ EDTA in a Coplin jar at $65^{\circ} \mathrm{C}$ for $1 \mathrm{~min}$. 

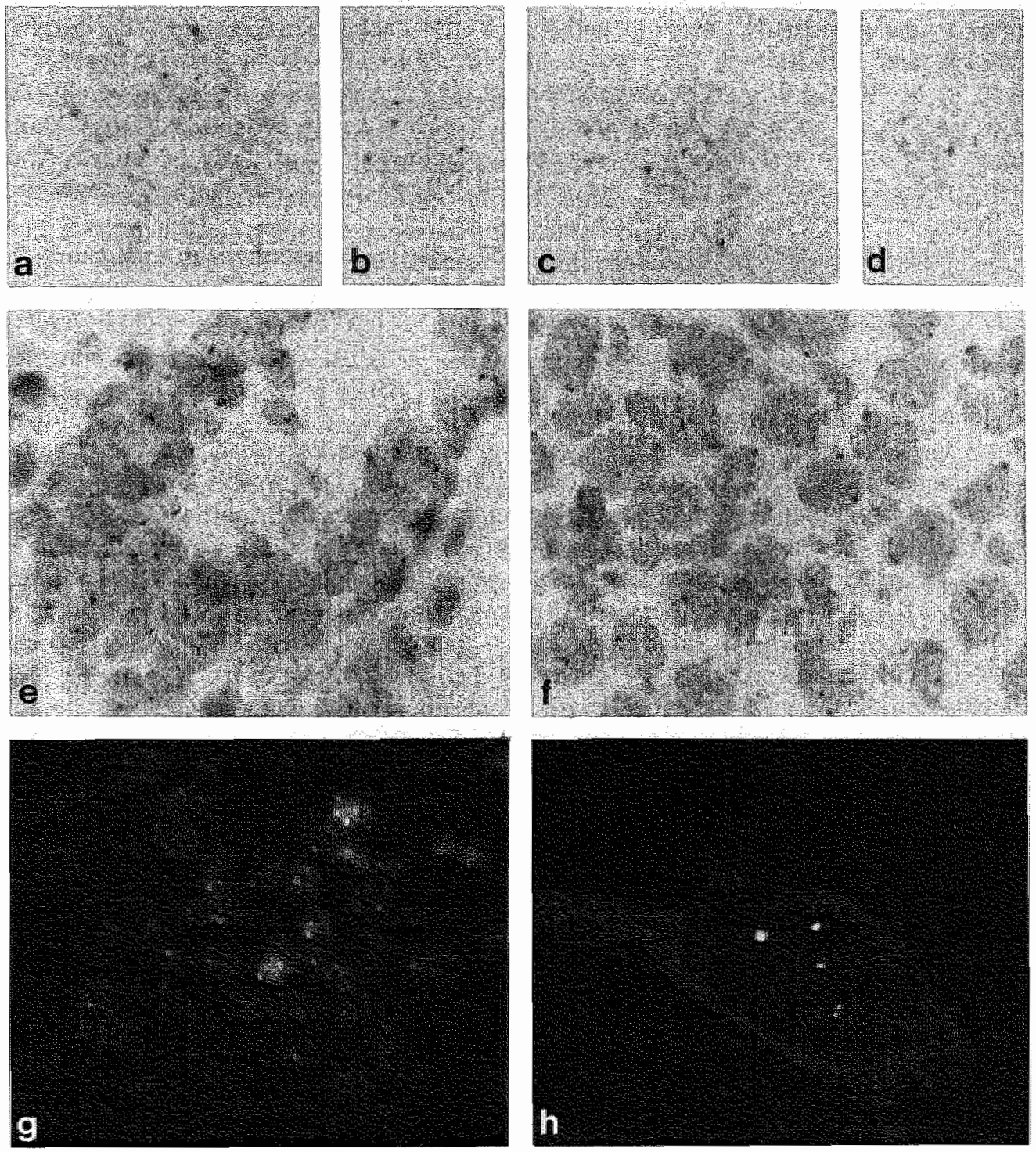
For sequential PRINS reactions, it was found to be necessary to incubate the slides prior to the next PRINS reaction with $0.025 \mathrm{mM}$ each of ddATP, ddGTP, ddCTP, ddTTP, and $1 \mathrm{U}$ Klenow DNA polymerase in $40 \mu \mathrm{l}$ of $0.05 \mathrm{M}$ Tris- $\mathrm{HCl}$, pH 7.2, $0.01 \mathrm{M} \mathrm{MgSO}_{4}, 0.01 \mathrm{mM}$ dithiothreitol, and $0.15 \mathrm{mg} / \mathrm{ml} \mathrm{BSA}$ under a coversip for $1 \mathrm{hr}$ at $37^{\circ} \mathrm{C}$ in order to prevent free $3^{\prime}$ ends of the newly synthesized DNA being used as primers for subsequent reactions. Following this step, the slides were dehydrated and air-dried before the next PRINS reaction with another primer and different reporter was run.

PRINS on tissue sections and immunostained cells was performed by application of the appropriate PRINS reaction mix under a coverslip, followed by denaturation of DNA for 2 min at $94^{\circ} \mathrm{C}$ on the thermal cycler, and the PRINS reaction as described above.

\section{Cytochemical detection of PRINS-labeled DNA}

After the final PRINS cycle the reaction was stopped as described above and slides were incubated in $4 \times$ SSC, $0.05 \%$ Triton X-100, $5 \%$ non-fat dry milk for 5 min at RT to reduce background staining in the detection procedures. Brightfield detection of incorporated hapten-dUTPs with enzyme precipitation reactions was performed as described previously (Speel et al., 1994b). Briefly, in single-target PRINS, biotindUTPs were visualized with horseradish peroxidase-conjugated avidin (AvPO, diluted 1:50; Dako), followed by either the diaminobenzidine (PO-DAB) or the tetramethylbenzidine (PO-TMB) reaction. In double-target PRINS, biotin- and digoxigenin-dUTPs were detected with incubations of AvPO, mouse anti-digoxin (MADig, diluted 1:2000) (Sigma), and GAMAPase, followed by the APase-Fast Red and the PO-DAB reaction. In triple-target PRINS, biotin-, digoxigenin-, and fluorescein-dUTPs were detected with incubations of AvPO, a mixture of MADig and rabbit anti-FITC (RAFITC, diluted 1:2000) (Dako), and a mixture of GAMAPase and PO-conjugated swine anti-rabbit IgG (SWARPO, diluted 1:100) (Dako). After the first detection layer, the PO-DAB reaction was performed, followed by an incubation in $0.01 \mathrm{~N} \mathrm{HCl}$ for $10 \mathrm{~min}$ at $\mathrm{RT}$ to inactivate any rest activity of the PO enzyme. After the last incubation step the APase-Fast Red and the PO-TMB reaction were performed. Cells were counterstained with hematoxylin and embedded in (a) $0.2 \mathrm{M}$

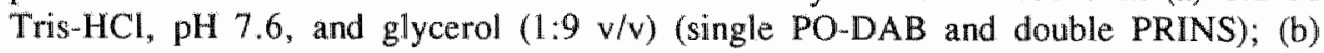
immersion oil (single PO-TMB PRINS); or (c) a thin protein layer (triple PRINS) (Speel et al., 1994b). The preparations could be stored permanently at $4^{\circ} \mathrm{C}$ and were evaluated with a standard Zeiss brightfield microscope.

Fluorescence detection of incorporated biotin-dUTPs was performed with FITCconjugated avidin (AvFrTC, diluted 1:500) (Vector, Brunschwig Chemie, Amsterdam, The Netherlands), whereas FluoroRed-dUTP could be visualized directly. Slides were mounted in Vectashield (Vector) containing $0.5 \mu \mathrm{g} / \mathrm{ml}$ of the DNA stain DAPI (Sigma). Slides were examined under a Zeiss Axiophot microscope equipped with filters for blue, green, and red fluorescence. Selected cells were either directly photographed or scanned with the BioRad MRC 600 confocal scanning laser microscope imaging system attached to the microscope. 


\section{RESULTS AND DISCUSSION}

To test the feasibility for applying three different enzyme precipitation reactions (PO$\mathrm{DAB}$, APase-Fast Red, and PO-TMB) combined with brightfield microscopy for the detection of multiple DNA targets with PRINS, single-, double-, and triple-target PRINS reactions were performed on normal human male chromosome preparations. Single-target PRINS with the centromere-specific primers for chromosomes 7,9 , and $Y$ was used to prove the applicability of these enzyme reactions for nucleic acid detection (data not shown). For double-target PRINS, the centromeres of chromosome 9 were labeled with biotin, followed by digoxigenin labeling of both chromosome 7 centromeres. The two labeled centromeric regions of each chromosome were enzyme cytochemically detected by the PO-DAB and APase-Fast Red reaction, respectively. The contrasting colors of the brown PO-DAB and red APase-Fast Red precipitates could be clearly distinguished on both hematoxylin counterstained metaphase chromosomes and interphase nuclei (Figures $1 \mathrm{a}$ and 1b). Combination of the PO-DAB and APase-Fast Red reactions with the PO-TMB reaction, in addition, made it possible to localize three PRINS-labeled DNA sequences on chromosome preparations. Figures $1 \mathrm{c}$ and $1 \mathrm{~d}$ evidently show the two copies of the centromeres of chromosome 7 and 9 together with one copy of the centromere of chromosome $Y$ in red, brown, and green, respectively, on hematoxylin counterstained chromosomes and nuclei. The entire detection procedure could be performed within a timespan of $3 \mathrm{hr}$, including mild acid treatment for inactivation of the first applied $\mathrm{PO}$ activity to avoid mixing of the PO-DAB and PO-TMB reactions, and embedding of the preparations in a protein layer to ensure permanent stabilization of the enzyme reaction products as well as optimal visualization of color contrast (Speel et al., 1994b).

It made no difference which primed sequence was labeled with which reporter (biotin, digoxigenin-, or fluorescein-dUTP) in multiple-target PRINS. In addition, a dideoxynucleotide reaction with Klenow DNA polymerase between successive PRINS reactions was found essential to block the free $3^{\prime}$ ends which remained after the former PRINS reaction. The sequence of the applied enzyme reactions, however, must always end with the PO-TMB reaction, since the resulting precipitate proved to be unstable in aqueous solutions with a $\mathrm{pH}$ above $\mathrm{pH} 6$ (e.g., dilution and washing buffers). The reliability of the simple brightfield detection procedure for the visualization of multiple PRINS-labeled DNA sequences was high for double- and triple-target PRINS, showing in almost all metaphases and interphase nuclei specific staining of the expected copies of chromosome centromeres. However, sometimes triple-target PRINS results were more difficult to interpret, especially in interphase nuclei, most probably due to background staining originating from priming at nicks in the target DNA or sites with aspecifically annealed oligonucleotides. Multiple-target brightfield $\mathbb{P R I N S}$ analysis requires metaphase preparations of high quality (no nicks), the use of specific primers, as well as optimized PRINS reaction conditions. When these requirements are fulfilled, this relatively simple technique can be utilized for the identification of chromosomes in cell preparations of, e.g., somatic cell hybrids and 
tumor tissue, as well as for the assignment of DNA sequences to specific chromosomal regions (Gosden and Lawson, 1994; Troyer et al., 1994).

To apply the PRINS technique on tissue material, $4 \mu \mathrm{m}$ thick frozen sections of niormal colon and bladder epithelium were subjected to different fixation procedures, including 10 min acetone at $-20^{\circ} \mathrm{C}, 10$ min methanol at $-20^{\circ} \mathrm{C}, 10$ min $70 \%$ ethanol at $-20^{\circ} \mathrm{C}, 10 \mathrm{~min} 70 \%$ ethanol/1\% formaldehyde at $-20^{\circ} \mathrm{C}$, and $10 \mathrm{~min}$ methanol:acetic acid $(3: 1 \mathrm{v} / \mathrm{v})$ at RT. Fixation was followed by a 10 -min pepsin digestion step at a concentration of $100 \mu \mathrm{g} / \mathrm{ml}$, to permeabilize the sections for penetration of PRINS reagents and conjugates. Thereafter, PRINS labeling with the centromere 9-specific primer was performed. Fixation of the sections in methanol:acetic acid in combination with pepsin digestion proved to be the most suitable pre-treatment procedure for efficient PRINS labeling and preservation of tissue morphology. Furthermore, denaturation of cellular DNA for 2 min at $94^{\circ} \mathrm{C}$ on the thermal cycler appeared to be much more efficient than a denaturation step for $2 \mathrm{~min}$ at $70^{\circ} \mathrm{C}$ in $70 \%$ formamide, $2 \times$ SSC before the PRINS reaction, as is routinely performed for metaphase spreads (Gosden and Lawson, 1994; Speel et al., 1995). Figures 1e and If show that detection of the centromeric regions of chromosome 9 can be achieved within $3 \mathrm{hr}$ using PRINS on optimal pre-treated sections of normal colon and bladdler epithelium, respectively. Biotin-dUTP incorporation was detected with AvPO, followed by the PO-TMB reaction (green spots, Figure le) or the PO-DAB reaction (brown spots, Figure 1f), performed as described above. The results proved to be very specific without suffering from high background levels. Quantification of the PRINS signals in these normal epithelial cells showed a majority of nuclei with two signals and some nuclei displaying only one signal, which is most probably caused by truncation of the nuclei during sectioning of the tissue samples (Hopman et al,, 1991). The same results were found after PRINS labeling with FluoroRed-dUTP incorporation and direct fluorescence detection (Figure 1g), demonstrating also the usefulness of this technique combined with fluorescence microscopy, especially, since no autofluorescence was observed in the tissue preparations analyzed.

The PRINS results with the chromosome 9-specific primer demonstrate, that this technique can now be used successfully on tissue sections to rapidly obtain both histological and genetic information. Thus, chromosome ploidy can be determined, and tumor heterogeneity may be recognized within a tissue section. For this purpose, PRINS primer sequences are now available specific for the centromeric regions of a number of human chromosomes (e.g., see Hindkjaer et al., 1994; Gosden and Lawson, 1994, 1995; Pellestor et al., 1995; Speel et al., 1995), including the chromosome 7-specific primer described earlier, which could also be utilized efficiently in single-target PRINS on this tissue material (data not shown). The feasibility of multiple-target PRINS on tissue sections as well as the detection of lowcopy and unique sequences are under study.

To examine the feasibility of combining the PRINS technique with protein ICC, we used as a model system the cell line C121-TN6, which expresses the human EGF receptor and contains 1 to 5 copies of human chromosome 7 on a mouse background, and the cell line $J 1-\mathrm{C} 14$, which expresses a cell-surface antigen recognized by MoAb 
163 A5 and contains human chromosome 11 on a Chinese hamster background. Since the PRINS procedure, which includes a proteolytic digestion step, can destroy antigenic determinants, we always applied ICC before the PRINS procedure. ICC staining was performed with the cytochemical APase-Fast Red reaction, since it produces a strongly red fluorescent reaction product that can be accurately localized and appears to be unaffected by the enzymatic pre-treatment steps as well as the entire PRINS procedure (see also Speel et al., 1994a). Application of the MAb EGFR1 to C121-TN6 cell preparations could be visualized by an APase-Fast Red reaction of $15 \mathrm{~min}$, resulting in accurate localization of the EGF receptor (Figure $1 \mathrm{~h}$, red fluorescence). Similarly, the cell-surface antigen could be visualized in $11-\mathrm{C} 14$ cells using MAb 163A5 (data not shown). As a control, the cell preparations were incubated with the non-relevant $\mathrm{MAb}$, resulting in no detectable antigen staining (data not shown). Combination of ICC and PRINS labeling required a proteolytic digestion step with pepsin after the APase-Fast Red precipitation reaction to obtain positive PRINS results. As a consequence, the EGF receptor could be visualized simultaneously with varying copy numbers of the chromosome 7 centromeres in the C121-TN6 cells (Figure 1h). In addition, with this combined procedure a specific cell-surface antigen staining pattern (MAb 163A5) could be localized in J1-Cl4 cells together with one copy of the centromere of chromosome 11 (data not shown). The APase-Fast Red precipitation reaction seemed not to influence the results of the subsequent PRINS procedure, since in the latter case most of the J1-C14 cells contained the chromosome 11-specific signal. Sometimes, however, high background levels were observed after PRINS labeling on these methanol/acetone fixed cell preparations, which could be the result of active nucleases that are not completely inactivated by this mild fixation procedure. Therefore, the use of other fixatives is now under investigation, which should preserve the antigen epitopes under study but destroy the activity of nucleases. The possibility to detect specific antigens and DNA targets simultaneously in the same cell, as described above, makes the combined ICC/PRINS procedure very suitable for defining the immunophenotype of tumor or hybrid cells with a specific chromosome content. Also in cases where only a few cells can be obtained for analysis (fine needle aspiration cytology, biopsy material), this procedure may prove to be of value.

In conclusion, we have demonstrated that brightfield detection of up to three specific PRINS-labeled DNA sequences in DNA counterstained metaphases and interphase nuclei of normal human lymphocytes is feasible, as well as the application of the PRINS technique to tissue sections and immunostained cells.

\section{Acknowledgements}

This work was supported by the Netherlands Organization for Scientific Research NWO, grant no. 900-534-102, and short-term fellowships of the Federation of European Biochemical Societies (FEBS) and the Dutch Royal Academy of Sciences (KNAW). 


\section{REFERENCES}

Abbo $S$, Dunford RP, Miller TE, Reader SM, King IP (1993) Primer-mediated in situ detection of the B-hordein gene cluster on barley chromosome 1H. Proc Natl Acad Sci USA 90:11821-11824

Bains MA, Agarwal R, Pringle JH, Hutchinson RM, Lauder I (1993) Flow cytometric quantitation of sequence-specific mRNA in hemapoletic cell suspensions by primer-induced in situ (PRINS) fhorescent nucleotide labeling. Exp Cell Res 208:321-326

Dorin JR, Inglis JD, Portious DI (1989) Selection for precise chromosomal targeting of adominant marker by homologous recombination. Science 243:1357-1360

Glaser T, Housman D, Lewis WH, Gerhard D, Jones C (1989) A fine-structure deletion map of chromosome $11 \mathrm{p}$ : analysis of $J 1$ series hybrids. Somat Cell Mol Genet 15:477-501

Gosden J, Lawson D (1994) Rapid chromosome identification by oligonucleotide-primed in situ DNA synthesis (PRINS). Hum Mol Genet 3:931-936

Gosden J, Lawson D (1995) Instant PRINS: a rapid method for chromosome identification by detecting repeated sequences in situ. Cytogenet Cell Genet 68:57-60

Hindkjiar J, Koch J, Terkelsen C, Brandt CA, Kölvraa S, Bolund L (1994) Fast, sensitive multicolor detection of nucleic acids in situ by primed in situ labeling (PRINS). Cytogenet Cell Genet 66:152$\mathbb{1 5 4}$

Hopman AHN, Van Hooren E, Van de Kaa CA, Vooijs GP, Ramaekers FCS (1991) Detection of numerical chromosome aberrations using in situ hybridization in paraffin sections of routinely processed bladder cancers. Modern Pathol 4:503-513

Koch J, Kolwraa S, Petersen KB, Gregersen N, Bolund L (1989) Oligonucleotide-priming methods for the chromosome-specific labelling of alpha satellite DNA in situ. Chromosoma 98:259-265

Mogensen J, Kolvraa S, Hindkjar J, Petersen S, Koch J, Nygård M, Jensen T, Gregersen N, Junker $S$, Bolund L (1991) Nonradioactive, sequence-specific detection of RNA in situ by primed in situ labeling (PRINS). Exp Cell Res 196:92-98

Pelllestor $\mathrm{F}$, Girardet $\mathrm{A}$, Lefort $\mathrm{G}$, Andréo B, Charlieu JP (1995) Use of the primed in situ labelling (PRINS) technique for a rapid detection of chromosomes $13,16,18,21, \mathrm{X}$ and $\mathrm{Y}$. Hum Genet $95: 112-17$

Speel EJM, Herbergs J, Ramaekers FCS, Hopman AHN (1994a) Combined immunocytochemistry and fluorescence in sim hybridization for simultaneous tricolor detection of cell cycle, genomic, and phenotypic parameters of tumor cells. J Histochem Cytochem 42:961-966

Speel EMM, Jansen MPHM, Ramaekers FCS, Hopman AHN (1994b) A novel triple-color detection procedure for brightfield microscopy, combining in situ hybridization with immunocytochemistry. I Histochem Cytochem 42:1299-1307

Speel EJM, Lawson D, Hopman AHN, Gosden J (1995) Multi-PRINS: multiple sequential oligonucleotide primed in situ DNA synthesis reactions label specific chromosomes and produce bands. Hum Genet 95:29-33

Troyer DL, Goad DW, Xie H, Rohrer GA, Alexander LJ, Beattle CW (1994) Use of direct in situ single-copy (DISC) PCR to physically map five porcine microsatellites. Cytogenet Cell Genet 67:199-204 


\section{SUMMARY}

In situ hybridization (ISH) allows to directly couple cytological and molecular information by visualizing nucleic acid sequences in the cellular context. Since its introduction in 1969, this technology has progressed from a laborious, timeconsuming approach detecting only high-copy nucleic acid sequences with low resolution to a relatively fast, specific, and sensitive procedure localizing sequences as small as $1-5 \mathrm{~kb}$ in morphologically preserved chromosomes, cells, and tissue. Although radioactive detection systems are still utilized for ISH, the development and improvement of non-radioactive probe-labeling and detection systems in the last decade has simplified this technology considerably and revolutionized its impact in biomedical research. Chapter 1 reviews the detection procedures that are currently used for ISH, applying fluorochromes, enzymes, and colloidal gold as reporter molecules. Along with a comparison of aspects such as sensitivity, microscopic resolution, and usefulness in multiple-target detection protocols, possible improvements and new developments are being discussed. In addition, an overview is presented of approaches that combine ISH and immunocytochemistry (ICC) for the simultaneous detection of nucleic acid sequences and cellular proteins in the same biological sample. The main goal of this thesis is to contribute to the further development and general applicability of non-radioactive DNA ISH technology (chapters 2-5) as well as the combination of ISH and ICC (chapters 5 and 6). Furthermore, the primed in situ (PRINS) labeling procedure has been evaluated as an alternative to ISH (chapters 7 and 8). For the experiments described, both interphase and metaphase preparations of normal and malignant human tissue and cultured cells were used.

Chapter 2 describes the interactions that occur between avidin and biotinylated molecules in sensitive ISH detection systems, such as the avidin biotinylated enzyme complex $(\mathrm{ABC})$ system and the amplification system using alternating detection layers of avidin conjugate and biotinylated goat anti-avidin antibody. By careful selection of different, subsequent detection layers and analysis of ISH signal intensities, more insight was obtained into the molecular basis of cytochemical complex formation. Since avidin molecules were found to be unsuited for the interconnection of two biotinylated molecular layers, other ways will have to be explored for increasing the ISH detection sensitivity. For example, one of the possibilities is the use of large conjugates consisting of polymer molecules (e.g., dextran sulfate or DNA) that are directly coupled to avidin or antibody molecules as well as reporter molecules.

In chapters 3-5, a number of enzyme cytochemical detection systems was further optimized for application to ISH. For this purpose, modified DNA probes were detected with avidin and/or antibody conjugates labeled with the enzymes alkaline phosphatase (APase), peroxidase ( $\mathrm{PO}$ ), or glucose oxidase, which produce differently colored, well localized, and permanent reaction products in appropriate precipitation reactions. Chapter 3 describes the use of the APase-Fast Red reaction, which produces a strongly red fluorescent precipitation product with extremely slow-fading properties. This enzyme cytochemical detection system exhibited at least the same sensitivity as conventional indirect fluorescence detection systems using fluorescein 
isothiocyanate (FITC) or Texas Red as fluorochromes, allowing the visualization of DNA sequences up to the single gene level. The APase-Fast Red reaction product could also be visualized with reflection contrast microscopy (RCM) and brightfield microscopy (BFM) along with eight other enzyme precipitation products (chapter 4). RCM proved to be a very sensitive technique that can generate high resolution images on basis of reflected light from enzymatically stained preparations. In particular, the application of a thin protein layer that protects the precipitation product extended the usefulness of this procedure to virtually every appropriate enzyme precipitation reaction, and allows multiple-staining methods to be explored. Analysis of the nine different enzyme reaction products tested revealed, that two main reflection colors could be obtained, i.e., white and yellow, enabling double-target ISH in RCM. Further development of the technique may lead to additional reflection colors, such as red for the PO-tetramethylbenzidine (TMB) precipitate, enabling triple-target ISH with RCM. Chapter 5 reports the use of BFM for the simultaneous in situ localization of up to three different DNA target sequences on basis of the contrasting brown PO$D A B$, red APase-Fast Red, and green PO-TMB precipitates. The entire detection procedure can be performed within three hours, including the embedding of the stained preparations in a thin protein layer, as described for $\mathrm{RCM}$, to ensure stabilization of the enzyme precipitates and optimal color contrast. Although only repetitive DNA targets were detected with this procedure, the described enzyme reactions may also be utilized to simultaneously detect multiple single gene sequences. In this respect, the recently introduced catalyzed reporter deposition (CARD) system for PO signal amplification may be of help to produce strong and clearly contrasting ISH signals.

Combination of ISH and ICC is presented in chapters 5 and 6 . In the protocols that were developed, ICC was always applied first, since protein epitopes are destroyed during the ISH procedure. For the ICC detection of cellular proteins, precipitating enzyme reaction products were used. These precipitates proved to be extremely stable during the ISH procedure and allowed the optimal enzymatic pre-treatment of the biological material. On the other hand, despite these precipitates, the ISH reagents were still able to reach and react with the target DNA. Using this approach, multipletarget ISH could be combined with ICC for BFM (chapter 5) as well as for fluorescence microscopy (chapter 6). The described methods enable the simultaneous analysis of phenotypic, genomic, and cell cycle parameters in the same sample and are thus valuable tools in the unraveling of molecular processes at the single cell level.

Chapters 7 and 8 deal with an alternative approach to label nucleic acid sequences in situ, i.e., the PRINS labeling method. It is based on the rapid annealing of specific oligonucleotide primers and subsequent primer extension by a polymerase reaction in the presence of labeled nucleotides. Chapter 7 describes the accurate localization of up to three different repetitive DNA sequences in chromosome preparations as a result of consecutive PRINS reactions and conventional fluorescence detection procedures. Alternatively, nucleic acid sequences could be visualized after PRINS with the triple-color detection procedure for BFM (chapter 8). Furthermore, new 
protocols for the application of the PRINS technique to frozen tissue sections and immunostained cells are presented in chapter 8. For this purpose, proteolytic pretreatment of the material is required to obtain reproducible results in morphologically preserved cell nuclei. The PRINS technique, thus, provides another way to detect specific nucleic acid sequences in different biological materials, but will have to be optimized with respect to sensitivity and specificity to be an acceptable alternative to the ISH technique. For this purpose, the use of repeated PRINS reactions or in situ polymerase chain reaction (in situ PCR) may be an interesting option. However, as long as the specific localization of single gene sequences in situ with this method is not routinely feasible, ISH is preferred. 



\section{SAMENVATTING}

In situ hybridisatie (ISH) maakt het mogelijk om cytologische en moleculaire informatie direct met elkaar te koppelen middels het zichtbaar maken van nucleïnezuren in de cel. Vanaf de introductie in 1969 heeft deze technologie zich ontwikkeld van een bewerkelijke, tijdrovende benadering met beperkte resolutie, die sllechts gebruikt kon worden voor het detecteren van nucleïnezuren die in hoog copie aantallen voorkomen, tot een relatief snelle, specifieke, en gevoelige procedure, waarmee genen van $1-5 \mathrm{~kb}$ te localiseren zijn in chromosomen, cellen, en weefsel met behoud van morfologie. Alhoewel radioactieve detectiesystemen nog steeds worden gebruikt voor ISH, heeft de ontwikkeling en verbetering van niet-radioactive probelabeling procedures en detectiesystemen deze technologie aanmerkelijk vereenvoudigd, waardoor toepassing in het biomedisch onderzoek op routinematige basis mogelijk is geworden. Hoofdstuk 1 geeft een overzicht van de ISH detectiesystemen die tegenwoordig worden toegepast en gebruik maken van fluorochromen, enzymen, en gouddeeljes als reporter moleculen. Naast een vergelijking van aspecten zoals gevoeligheid, microscopische resolutie, en bruikbaarheid in meervoudige nucleinezuur detectieprotocollen, worden mogelijke verbeteringen en nieuwe ontwikkelingen bediscussieerd. Voorts wordt een overzicht gegeven van methodes die ISH met immunocytochemie (ICC) combineren voor de simultane detectie van nucleïnezuren en eiwitten in hetzelfde biologische preparaat. Het hoofddoel van dit proefschrift is een bijdrage te leveren aan de verdere ontwikkeling en algemene toepasbaarheid van zowel de niet-radioactieve DNA ISH technologie (hoofdstukken 2-5) als van de combinatie van ISH en ICC (hoofdstukken 5 en 6). Daarnaast is de "primed in situ" (PRINS) labeling procedure geëvalueerd als een alternatief voor de ISH techniek. Voor de beschreven experimenten zijn zowel interfase als metafase preparaten gebruikt van normale en maligne humane weefsels en celkweken.

Hoofdstuk 2 beschrijft de interacties tussen avidine en gebiotinyleerde moleculen die gebruikt worden in gevoelige ISH detectiesystemen, zoals het avidine gebiotinyleerd enzym complex (ABC) systeem en het amplificatiesysteem dat gebruik maakt van afwisselende lagen avidine conjugaat en gebiotinyleerd geit anti-avidine antilichaam. Door middel van nauwkeurig gekozen, opeenvolgende detectielagen en de analyse van de daaruit resulterende ISH signaalintensiteit kon meer inzicht worden verkregen in de moleculaire basis van cytochemische complexvorming. Omdat avidine moleculen echter ongeschikt bleken te zijn voor het verbinden van twee gebiotinyleerde moleculaire lagen, zullen andere manieren moeten worden onderzocht voor het verhogen van de ISH detectiegevoeligheid. Een van de mogelijkheden is bijvoorbeeld het gebruik van grote conjugaten, bestaande uit polymeermoleculen (zoals dextraansulfaat of DNA) die direct gekoppeld zijn aan avidine of antilichaam moleculen en tegelijkertijd aan reporter moleculen.

In de hoofdstukken 3-5 wordt de optimalisatie van een aantal enzymcytochemische detectiesystemen voor toepassing in ISH beschreven. Hiervoor werden gemodificeerde DNA probes gedetecteerd met avidine en/of antilichaam conjugaten, die gelabeld waren met alkalische fosfatase (APase), peroxidase (PO), of glucose oxidase, welke 
werschillend gekleurde, goed gelocaliseerde en permanente reactieproducten genereren. Hoofdstuk 3 beschrijft het gebruik van de APase-Fast Red reactie, die een sterk rood fluorescerend precipitatieprodukt oplevert dat tijdens belichting slechts geringe doving vertoont. Dit enzymcytochemisch detectiesysteem bleek tenminste dezelfde gevoeligheid te bezitten als conventionele fluorescentie detectiesystemen, gebruik makend van fluoresceine isothiocyanaat (FITC) of Texas Red als fluorochromen, waardoor DNA sequenties tot op gen niveau zichtbaar konden worden gemaakt. Het APase-Fast Red reactieprodukt kon ook gevisualliseerd worden met reflectie contrast microscopie (RCM) en helderveld microscopie (HVM) evenals acht andere enzym precipitatieprodukten (hoofdstuk 4), RCM is een zeer gevoelige techniek, waarmee beelden met een hoge resolutie gegenereerd kunnen worden op basis van gereflecteerd licht afkomstig van enzymatisch gekleurde preparaten. Met name het aanbrengen van een dun eiwitlaagje ter afscherming van het precipitatieproduct heeft de bruikbaarheid van deze procedure uitgebreid tot elke geschikte enzymprecipitatie reactie, waardoor meervoudige kleuringsmethoden kunnen worden ontwikkeld. Analyse van de negen geteste enzym reactieprodukten toonde aan dat twee reflectiekleuren verkregen kunnen worden, namelijk wit en geel, waardoor ISH detectie van twee verschillende nucleïnezuren met behulp van RCM mogelijk wordt. Verdere ontwikkeling van de techniek kan leiden tot extra reflectiekleuren, zoals het rood reflecterende PO-tetramethylbenzidine (TMB) precipitaat, waardoor een drievoudige detectie mogelijk wordt. Hoofdstuk 5 belicht het gebruik van HVM voor de simultane in situ localisatie van drie verschillende DNA sequenties op basis van het contrast tussen het bruine PO-DAB, rode APase-Fast Red, en groene POTMB precipitaat. De gehele detectieprocedure kan binnen drie uur worden uitgevoerd, inclusief het afdekken van de gekleurde preparaten met een dun eiwitlaagje, zoals beschreven voor RCM, om stabilisering van de enzymprecipitaten en een optimaal kleurcontrast te waarborgen. Alhoewel tot nu toe alleen repeterende DNA sequenties werden gedetecteerd met deze procedure, kunnen de beschreven enzymreacties mogelijk ook benut worden om meerdere gensequenties simultaan zichtbaar te maken. Hierbij zou het recentelijk geintroduceerde "catalyzed reporter deposition" (CARD) systeem voor PO signaal amplificatie van nut kunnen zijn middels het produceren van sterke en duidelijk contrasterende ISH signalen.

De combinatie van ISH met ICC wordt beschreven in de hoofdstukken 5 en 6 . In de ontwikkelde protocollen wordt steeds begonnen met de ICC detectie, omdat eiwitepitopen kunnen worden vermietigd tijdens de ISH procedure. Voor de ICC detectie van cellulaire eiwitten worden precipiterende enzym reactieprodukten gebruikt. De precipitaten blijken namelijk stabiel tijdens de ISH procedure en maken daardoor een optimale voorbehandeling van het biologische materiaal mogelijk. Ondanks de aanwezigheid van deze precipitaten, zijn de ISH reagentia toch in staat DNA te bereiken en ermee te reageren. Met behulp van deze benadering kan meervoudige nucleïnezuurdetectie worden gecombineerd met ICC voor gebruik in zowel HVM (hoofdstuk 5) als in fluorescentie microscopie (hoofdstuk 6). De beschreven methoden maken het mogelijk om fenotypische, genomische en celcyclus parameters gelijktijdig 
te analyseren in hetzelfde preparaat en zijn dus waardevolle instrumenten bij het ontrafelen van moleculaire processen op cellulair niveau.

De hoofdstukken 7 en 8 behandelen een alternatieve benadering voor in situ nucleinezuurlabeling, namelijk de PRINS methode. Deze techniek is gebaseerd op de snelle hybridisatie van specifieke oligonucleotide primers en daaropvolgende primerextensie middels een polymerase reactie in de aanwezigheid van gelabelde nucleotiden. Hoofdstuk 7 beschrijft de nauwkeurige localisatie van drie verschillende repeterende DNA sequenties in chromosoompreparaten na opeenvolgende PRINS reacties en conventionele fluorescentie detectieprocedures. Deze nucleinezuren kunnen na de PRINS reacties ook zichtbaar worden gemaakt met de driekleuren HVM detectie procedure (hoofdstuk 8). Voorts worden nieuwe protocollen voor de toepassing van de PRINS techniek op vriescoupes en immunocytochemisch gekleurde cellen gepresenteerd. Hiervoor bleek proteolytische voorbehandeling van het materiaal noodzakelijk om reproduceerbare resultaten te verkrijgen in morfologisch intacte celkernen. De PRINS techniek maakt het mogelijk specifieke nucleinezuren te detecteren in verschillende typen biologisch materiaal, maar zal verder moeten worden geoptimaliseerd met betrekking tot gevoeligheid en specificiteit om een acceptabel alternatief te kunnen zijn voor de ISH techniek. Het gebruik van herhaalde PRINS reacties oftewel in situ polymerase ketting reactie (in situ PCR) kan hiervoor een interessante optie zijn. Echter, zolang de specifieke localisatie van gensequenties in situ niet routinematig mogelijk is met behulp van deze methode, zall de voorkeur uitgaan naar ISH. 



\section{LIST OF PUBLICATIONS}

Speel EIM, Schutte B, Ramaekers FCS, Hopman AHN (1992) The effect of avidin-biotin interactions in detection systems for in situ hybridization. J Histochem Cytochem 40:135 141

Speel EJM, Schutte B, Wiegant J, Ramaekers FCS, Hopman AHN (1992) A novel fluorescence detection method for in situ hybridization, based on the alkaline phosphatase-fast red reaction. I Histochem Cytochem 40:1299-1308.

Speel EJM, Kamps M, Bonnet J, Ramaekers FCS, Hopman AHN (1993) Multicolour preparations for in situ hybridization using precipitating enzyme cytochemistry in combination with reflection contrast microscopy. Histochemistry 100:357-366

Speel EJM, Herbergs $J$, Ramaekers FCS, Hopman AHN (1994) Combined immunocytochemistry and fluorescence in situ hybridization for simultaneous tricolor detection of cell cycle, genomic, and phenotypic parameters of tumor cells. J Histochem Cytochem 42:961-966

Speel EJM, Schutte B, Ramaekers FCS, Hopman AHN (1994) Non-fading high sensitivity confocal fluorescence imaging for in situ hybridization and immunocytochemistry. Biorad Application Note 14.

Speel EJM, Jansen MPHM, Ramaekers FCS, Hopman AHN (1994) A novel triple-color detection procedure for brightfield microscopy, combining in situ hybridization with inmunocytochemistry. I Histochem Cytochem 42:1299-1307

Speel EJM, Lawson D, Hopman AHN, Gosden J (1995) Multi-PRINS: multiple sequential oligonucleotide primed in situ DNA synthesis reactions label specific chromosomes and produce bands. Hum Genet 95:29-33

Speel EJM, Ramaekers FCS, Hopman AHN (1995) Detection systems for in situ hybridization, and the combination with immunocytochemistry. Submitted for publication

Hopman AHN, Speel EJM, Voorter CEM, Ramaekers FCS (1995) Probe labelling methods. In Levy ER, Herrington CS (eds): Non-isotopic methodes in molecular biology: a practical approach. IRL Press, Oxford University Press, Oxford, in press

Hopman AHN, Voorter CEM, Speel EJM, Ramaekers FCS, Voojis GP (1995) Detection of genetic changes in cancer by interphase cytogenetics and comparative genomic hybridization. In Polak, Wharton, McGee (eds): In situ hybridization: principles and practice. Oxford University Press, Oxford, in press

Martini E, Speel EJM, Geraedts JPM, Ramaekers FCS, Hopman AHN (1995) Application of different in situ hybridization detection methods for human sperm analysis. Hum Reprod, in press

Herbergs J, Speel EJM, Ramaekers FCS, De Bruine AP, Arends JW, Hopman AHN (1995) Combination of lamin immunocytochemistry and in situ hybridization for the analysis of chromosome copy numbers in tumor cell areas with high nuclear density. Submitted for publication 



\section{ENZYME CYTOCHEMICAL REACTION PROTOCOLS FOR ISH AND ICC}

\section{Alkaline phosphatase (APase) cytochemistry}

\section{APase-Fast Red reaction}

(red color; Speel et al., 1992)

Mix just before use: $\quad-4 \mathrm{ml} 0.2 \mathrm{M}$ Tris- $\mathrm{HCl}$, pH 8.5 , containing $10 \mathrm{mM} \mathrm{MgCl}$ and $5 \%$ polyvinyl alcohol (PVA, Mw 40,000; Sigma)

- $250 \mu \mathrm{l}$ buffer without PVA containing $1 \mathrm{mg}$ naphthol-ASMXphosphate (Sigma)

- $750 \mu l$ buffer without PVA containing 5 mg Fast Red TR salt (Sigma)

- Incubate slides with $100 \mu 1$ under a coverslip for $5-15 \mathrm{~min}$ at $37^{\circ} \mathrm{C}$

- Wash $3 \times 5$ min with PBS

- Coverslip with an aqueous-based mounting medium

APase-ASMX/Fast Blue and APase-ASGR/Fast reaction

(blue and green color; Hoeltke et al., 1992)

- For ASMX/Fast Blue reaction, see protocol for APase-Fast Red reaction above and substitute Fast Red TR for Fast Blue BN (Sigma or Boehringer)

For ASGR/Fast Blue reaction, see protocol for APase-Fast Red reaction above and substitute 5 $\mathrm{mg}$ Fast Red TR for $3 \mathrm{mg}$ Fast Blue BN, and $1 \mathrm{mg}$ naphthol-ASMX-phosphate for $2-3 \mathrm{mg}$ naphthol-ASGR-phosphate (Sigma or Boehringer)

\section{APase-NBT/BCIP reaction}

(purple color; McGadey, 1970)

- Dissolve $1.8 \mathrm{mg}$ 5-bromo-4-chloro-3-indolyl-phosphate (BCIP; Boehringer) in $100 \mu \mathrm{N}, \mathrm{N}$ dimethylformamide, and $3.3 \mathrm{mg}$ nitro blue tetrazolium salt (NBT; Boehringer) in $660 \mu \mathrm{l}$ Milli $\mathrm{Q}$, and add subsequently to $9.24 \mathrm{ml} 0.2 \mathrm{M}$ Tris- $\mathrm{HCl}, \mathrm{pH} 8.5$, containing $10 \mathrm{mM} \mathrm{MgCl} \mathrm{M}_{2}$ (and optionally $5 \%$ PVA)

- Incubate slides with $100 \mu$ under a coverslip for $15-60$ min at $37^{\circ} \mathrm{C}$

- Wash 3x5 min with PBS

- Coverslip with an aqueous-based mounting medium

\section{APase-NBT/BCIP/INT reaction}

(brown color; Speel et al., 1993)

- Perform according to the manufacturer"s instructions (Dako, code no. K599)

\section{APase-New Fuchsin reaction}

(red color; Malik and Daymon, 1982)

- Mix just before use:

- $4.69 \mathrm{mll} 0.2 \mathrm{M}$ Tris-HCl, $\mathrm{pH} 8.5$, containing $10 \mathrm{mM} \mathrm{MgCl}$ and optionally $5 \%$ PVA

- $250 \mu \mathrm{l}$ buffer without PVA containing I mg naphthol-ASMXphosphate (Sigma)

- $60 \mu \mathrm{l}$ of a mixture of $30 \mu \mathrm{l} \mathrm{New} \mathrm{Fuchsin} \mathrm{in} 2 \mathrm{M} \mathrm{HCl}(40 \mathrm{mg} / \mathrm{ml}$ stock) and $30 \mu l \mathrm{NaNO}_{2}$ in Milli $\mathrm{Q}(40 \mathrm{mg} / \mathrm{ml})$

Incubate slides with $100 \mu$ l under a coverslip for $5-15$ min at $37^{\circ} \mathrm{C}$

- Wash 3x5 min with PBS and dehydrate optionally

- Coverslip with an aqueous-based mounting medium 
- Add $2.5 \mu \mathrm{l}$ of a stock sollution of $20 \mathrm{mg} / \mathrm{ml} 5$-bromo-4chloro-3-indolyl-B-D-galactoside (BClG; Life Technologies) in N, N-dinethylformamide to $100 \mu \mathrm{PBS}$ containing $0.9 \mathrm{mM} \mathrm{MgCl}, 3 \mathrm{mM}$ potassium ferricyanide, and $3 \mathrm{mM}$ potassium ferrocyanide.

- Incubate sllides with $100 \mu 1$ under a coverslip for $15-60 \mathrm{~min}$ at $37^{\circ} \mathrm{C}$

- Wask $3 \times 5$ min with PBS and dehydrate optionally

- Cowerslip with an aqueous- or organic-based mounting medium

\section{Horseradish peroxidase (PO) cytochemistry}

\section{PO-ARC reaction}

(red color; Graham et al., 1965)

- Mix $2.5 \mathrm{ml} \mathrm{3,3-amino-9-ethyl} \mathrm{carbazole} \mathrm{(AEC;} \mathrm{Sigma)} \mathrm{in} \mathrm{N}, \mathrm{N}$-dimethylformamide (10 mg/ml stock) with $47.5 \mathrm{ml} 50 \mathrm{mM} \mathrm{NaAc}$ buffer, pH 4.9

- Filter directly

- Add $20 \mu \mathrm{l} 30 \% \mathrm{H}_{2} \mathrm{O}_{2}$ just before use

- Incubate slides for 10 min at room temperature

- Wash 3x5 min with PBS

- Coverslip with and aqueous-based mounting medium

\section{PO-Chloronaphthol reaction}

(purple color; Nakane, 1968)

- Dissolve $6 \mathrm{mg}$ 4-chloro-1-naphthol (Merck) in 0.2 $\mathrm{ml} \mathrm{100 \%} \mathrm{ethanol} \mathrm{and} \mathrm{add} \mathrm{to} 10 \mathrm{ml} 0.05 \mathrm{M}$ Tris $-\mathrm{HCl}, \mathrm{pH} 7.6$

- Filter directly

- Add $10 \mu \mathrm{l} 30 \% \mathrm{H}_{2} \mathrm{O}_{2}$ just before use

- Incubate slides with $100 \mu \mathrm{l}$ under a coverslip for $10 \mathrm{~min}$ at room temperature

- Wash $3 \times 5$ min with Milli Q

- Coverslip with an aqueous-based mounting medium

\section{PO-DAB resaction}

(brown color; Graham and Karnovsky, 1966)

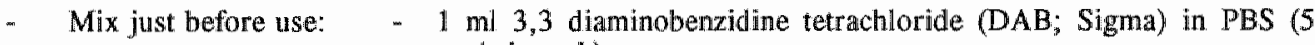
$\mathrm{m} \mathrm{g} / \mathrm{ml}$ l stock)

- 9 mil PBS/0.1 M imidazole, pH 7.6

- $10 \mu 30 \% \mathrm{H}_{2} \mathrm{O}_{2}$

- Incubate slides with $100 \mu$ under a coverslip for $5-15$ min at $37^{\circ} \mathrm{C}$

- Wash $3 \times 5$ min with PBS and dehydrate optionally

- Coverslip with an aqueous- or organic-based mounting medium

\section{PO-TMB reaction}

(green color; Speel et al., 1994)

- Dissolve $100 \mathrm{mg}$ sodium tungstate (Sigma) in $7.5 \mathrm{ml} 100 \mathrm{mM}$ citrate-phosphate buffer, pH 5.1 , and bring back the $\mathrm{pH}$ afterwards to $\mathrm{pH} 5.0-5.5$ with $37 \% \mathrm{HCl}$

- Dissolve just before use, respectively, $20 \mathrm{mg}$ dioctyl sodium sulfosuccinate (Sigma) and $6 \mathrm{mg}$ $3,3^{*}, 5,5^{\prime}$-tetramethylbenzidine (TMB, Sigma) in $2,5 \mathrm{ml} 100 \%$ ethanol at $80^{\circ} \mathrm{C}$

- Mix both solutions and add $10 \mu \mathrm{l} 30 \% \mathrm{H}_{2} \mathrm{O}_{2}$

- Incubate slides with $100 \mu$ under a coverslip for $1-2$ min at $37^{\circ} \mathrm{C}$

- Wash $3 x 1 \mathrm{~min}$ with ice-cold $0.1 \mathrm{M}$ phosphate buffer $\mathrm{pH} 6.0$ and dehydrate optionally

- Coverslip with an organic-based mounting medium or immersion oil 


\section{Glucose oxidase (GO) cylochemistry}

\section{GO-NBT/PMS reaction}

(purple color; Gown, 1988)

Make stock solutions of $2 \mathrm{mg} / \mathrm{ml}$ phenozine methosulphate (PMS; Sigma), $5 \mathrm{mg} / \mathrm{ml} \mathrm{NBT}$, and $100 \mathrm{mg} / \mathrm{mll} \mathrm{B}-\mathrm{D}$-glucose (Merck) in Milli $Q$

Prepare substrate solution containing $0.05 \mathrm{M}$ Tris-HCl, pH $8.5,10 \mathrm{mg} / \mathrm{ml}$ H-D-glucose, 1,35 $\mathrm{mg} / \mathrm{ml} \mathrm{NBT}$, and $0.25 \mathrm{mg} / \mathrm{ml}$ PMS

Incubate slides with $100 \mu$ under acoverslip for $15-60$ min at $37^{\circ} \mathrm{C}$

Wash $3 \times 5$ min with PBS

Coverslip with an aqueous-based mounting medium

Bondi A, Chieregatti G, Eusebi V, Fulcheri E, Bussolati $G$ (1982) The use of $\beta$-galactosidase as a tracer in immunocytochemistry. Histochemistry 76:153-158

Gown AM (1988) Immunoglucose oxidase methods in immunohistochemistry. In DeLellis RA (eds): Advances in immunohistochemistry. New York, Raven Press, pp 31-45

Graham RC, Karnovsky MJ (1966) The early stages of absorption of injected horseradish peroxidase in the proximal tubules of mouse kidney: ultrastructural cytochemistry by a new technique. J Histochem Cytochem 14:291 302

Graham RC, Lundholm U, Karnovsky MJ (1965) Cytochemical demonstration of peroxidase activity with 3-amino-9-ethyl carbazole. J Histochem Cytochem 13:150-152

Hoeltke HJ, Ettl I, Finken M, West S, Kunz W (1992) Multiple nucleic acid labeling and rainbow detection. Anal Biochem 207:24-31

Malik NJ, Daymon ME (1982) Improved double immunoenzyme labelling using alkaline phosphatase and horseradish peroxidase. J Clin Pathol 35:1092-1094

MoGadey J (1970) A tetrazolium method for non-specific alkaline phosphatase. Histochemistry $23: 180-184$

Nakane PK (1968) Simultaneous localization of multiple tissue antigens using the peroxidase-labeled antibody method: A study on pituitary glands of the rat. J Hüstochem Cytochem 16:557-560

Speel EJM, Schutte B, Wiegant J, Ramaekers FCS, Hopman AHN (1992) A nowel fluorescence detection method for in situ hybridization, based on the alkaline phosphatase-fist red reaction. J Histochem Cytochem 40:1299-1308 (Chapter 3)

Speel EJM, Kamps M, Bonnet J, Ramaekers FCS, Hopman AHN (1993) Multicolour preparations for in situ hybridization using precipitating enzyme cytochemistry in combination with reflection contrast microscopy. Histochemistry 100:357-366 (Chapter 4)

Speel EJM, Jansen MPHM, Ramaekers FCS, Hopman AHN (1994) A novel triple-color detection procedure for brightfield microscopy, combining in situ hybridization with immunocytochemistry. I Histochem Cytochem 42:1299-1307 (Chapter 5) 



\section{DANKWOORD}

Enne...? Nu het boekje af is wil ik op deze plaats graag iedereen bedanken die een bijdrage heeft geleverd aan de totstandkoming ervan, of mij in enig ander opzicht tot steun is geweest gedurende mijn promotietijd.

Medewerkers van het Instituut voor Pathologie van het St. Radboudziekenhuis te Nijmegen, bedankt voor de prettige tijd die ik bij jullie heb gehad tijdens mijn prépromotietijd als erkend gewetensbezwaarde in 1989 en 1990. In het bijzonder wil ik Pino Poddighe en Olof Moesker bedanken, die mij op het ISH lab bij de eerste schreden op het gebied van de in situ hybridisatie hebben geholpen.

Collega's van de afdeling Cytochemie en Cytometrie van het Sylvius Laboratorium te Leiden, en met name Joop Wiegant, Jan Bonnet, en Ton Raap, will ik bedanken voor hun belangstelling en deskundige adviezen betreffende de in situ hybridisatie techniek, zowel tijdens mijn regelmatige bezoeken aan Leiden als daarbuiten. Ook de gezelligheid buiten werktijd en rondom de promoties heb ik zeer gewaardeerd.

I would like to thank John Gosden and Diane Lawson from the MRC Human Genetics Unit, Western General Hospital in Edinburgh, Scotland for their hospitality, and helpful advise on how to perform PRINS on cell preparations during my two months stay in March and November 1994. Furthermore, I would like to thank the other people in the Molecular Genetics section for their interest and sociability in the lab and during christmas lunches and pub hours. Finally, Yoshiro Shibasaki and Andreas Schedl, many thanks for the pleasant stay in this great flat of yours.

Het grootste gedeelte van mijn promotietijd heb ik echter doorgebracht op de vakgroep Moleculaire Celbiologie \& Genetica van de Rijksuniversiteit Limburg te Maastricht, waar ik vanaf de begintijd op het oude BMC de afdeling heb zien groeien tot wat die vandaag de dag is. Alle labgenoten die ik gedurende deze periode heb gekend wil ik hierbij van harte danken voor hun belangstelling, collegiale samenwerking en gezelligheid. In het bijzonder wil ik mijn kamergenoten en paranimfen Jos Herbergs en Maurice Jansen bedanken voor hun steun en vriendschap en hun aandeel in mijn promotie-onderzoek. Ook Miriam "GoPo" Kamps en student Eric "wauw" Bindels ben ik zeer erkentelijk voor hun experimentele bijdragen, alsmede prins Bert II van Eijsden (Bert Schutte) voor zijn hulp bij het werk met de confocale microscoop, Mieke Henfling, Helma Kuijpers, Josepha Albrechts en Albert van Geelen (Medische Microbiologie) voor hun aandeel in het kweek en spatwerk, en de overige leden van de ISH groep (Edith Coonen, Monique Ummelen, Christien Voorter, Elena Martini, Annick Peeters, Marie Hellene Lenders) voor hun nauwe betrokkenheid bij het onderzoek.

En dan natuurlijk mijn co-promotor Dr. Ton Hopman en promotor Prof. dr. Frans Ramaekers: beste Ton en Frans, gedurende de zeven jaar dat wij elkaar nu kennen zijn jullie een ideaal duo voor mij gebleken. Ton, jouw technische begeleiding en onze vele discussies en avonden in Eijsden over hoe het nou allemaal precies werkt hebben mij altijd enorm gestimuleerd. Frans, jouw interesse, enthousiasme, organisatorische steun en overzicht vulde dit perfect aan. lk hoop dan ook nog vaak gebruik te kunnen maken van deze unieke situatie.

Tot slot, Evelien ...! 



\section{CURRICULUM VITAE}

Ernst Jan Maria Speel werd op 21 september 1964 geboren te 's-Hertogenbosch. Na het behalen van het atheneum B diploma aan het Maasland College te Oss in juni 1982, werd in hetzelfde jaar begonnen met de studie Biologie aan de Katholieke Universiteit te Nijmegen. In 1985 werd het diploma deskundigheid stralingshygiène niveau 3 behaald. Het doctoraal examen met als hoofdvak Moleculaire Biologie (Prof. dr. J.G.G. Schoenmakers) en bijvak Medische Parasitologie (Prof. dr. J.H.E.Th. Meuwissen) werd behaald in oktober 1988. Van augustus 1989 tot december 1990 deed hij zijn eerste in situ hybridisatie ervaring op als erkend gewetensbezwaarde op het Instituut voor Pathologie (Prof. dr. G.P. Vooijs) van het St. Radboudziekenhuis te Nijmegen onder leiding van Dr.A.H.N. Hopman en Dr. F.C.S. Ramaekers.

In december 1990 werd gestart met het in dit proefschrift beschreven onderzoek bij de vakgroep Moleculaire Celbiologie \& Genetica (Prof. dr. F.C.S. Ramaekers) van de Rijksuniversiteit Limburg te Maastricht. Het AIO onderzoek, dat onder leiding van Dr. A.H.N. Hopman is uitgevoerd, was ondergebracht bij het Cardiovasculair Research Instituut Maastricht (CARIM) en werd mede gefinancierd door NWO. Met behulp van een beurs van de "Federation of European Biochemical Societies" (FEBS) en de Koninklijke Nederlandse Academie van Wetenschappen (KNAW) kon tevens twee maanden worden gewerkt op de "MRC Human Genetics Unit" van het "Western Generall Hospital" te Edinburgh, Schotland (Dr. J.R. Gosden).

Sinds decemer 1994 is hij werkzaam als post-doctoraal onderzoeksmedewerker bij de vakgroep Moleculaire Celbiologie \& Genetica van de Rijksuniversiteit Limburg. 